ELIZANGELA DOS ANJOS SILVA

Avaliação morfológica e molecular pós-tratamento com os fatores hepatotróficos, da cirrose hepática induzida em ratas pela tioacetamida: análise a curto e longo prazo 


\section{Avaliação morfológica e molecular pós-tratamento com os fatores hepatotróficos, da cirrose hepática induzida em ratas pela tioacetamida: análise a curto e longo prazo}

Tese apresentada ao Programa de Pós-Graduação em Anatomia dos Animais Domésticos e Silvestres da Faculdade de Medicina Veterinária e Zootecnia da Universidade de São Paulo para obtenção do título de Doutor em Ciências

Departamento:

Cirurgia

Área de Concentração:

Anatomia dos Animais Domésticos e Silvestres

Orientador:

Prof. Dr. Francisco Javier Hernandez-Blazquez 
Autorizo a reprodução parcial ou total desta obra, para fins acadêmicos, desde que citada a fonte.

DADOS INTERNACIONAIS DE CATALOGAÇÃO-NA-PUBLICAÇÃO

(Biblioteca Virginie Buff D’Ápice da Faculdade de Medicina Veterinária e Zootecnia da Universidade de São Paulo)

Silva, Elizangela dos Anjos

Avaliação morfológica e molecular pós-tratamento com os fatores hepatotróficos, da cirrose hepática induzida em ratas pela tioacetamida: análise a curto e longo prazo / Elizangela dos Anjos Silva. -- 2011.

$180 \mathrm{f.}:$ il.

Tese (Doutorado) - Universidade de São Paulo. Faculdade de Medicina Veterinária e Zootecnia. Departamento de Cirurgia, São Paulo, 2011.

Programa de Pós-Graduação: Anatomia dos Animais Domésticos e Silvestres.

Área de concentração: Anatomia dos Animais Domésticos e Silvestres.

Orientador: Prof. Dr. Francisco Javier Hernandez-Blazquez.

1. Fibrose. 2. Cirrose hepática murina. 3. Matriz extracelular. 4. Fatores hepatotróficos. 5. Tioacetamida. I. Título. 


\section{UNIVERSIDADE DE SÃO PAULO}

Faculdade de Medicina Veterinária e Zootecnia

Comissão Bioética

\section{CERTIFICADO}

Certificamos que o Projeto intitulado "Efeito em longo prazo de fatores hepatotróficos sobre a morfologia, função e expressão de Col a1, MMPII e TGFß1 na cirrose hepática em ratos (modelo da tioacetamida)", protocolado sob o no1121/2007, utilizando 60 (sessenta) ratos, sob a responsabilidade do Prof. Dr. Francisco Javier Hernandez Blazquez, está de acordo com os princípios éticos de experimentação animal da Comissão de Bioética da Faculdade de Medicina Veterinária e Zootecnia da Universidade de São Paulo e foi aprovado em reunião de $22 / 08 / 07$.

We certify that the Research "Long term effect of hepatotrophic factor on the morphology, function and expression of Col a1, MMPII and TGFß1 in the hepatic cirrhosis in rats (model of the thioacetamide)", protocol number 1121/2007, utilizing 60 (sixthly) rats, under the responsibility Prof. Dr. Francisco Javier Hernandez Blazquez, agree with Ethical Principles in Animal Research adopted by Bioethic Commission of the School of Veterinary Medicine and Zootechny of University of São Paulo and was approved in the meeting of day 08/22/2007.

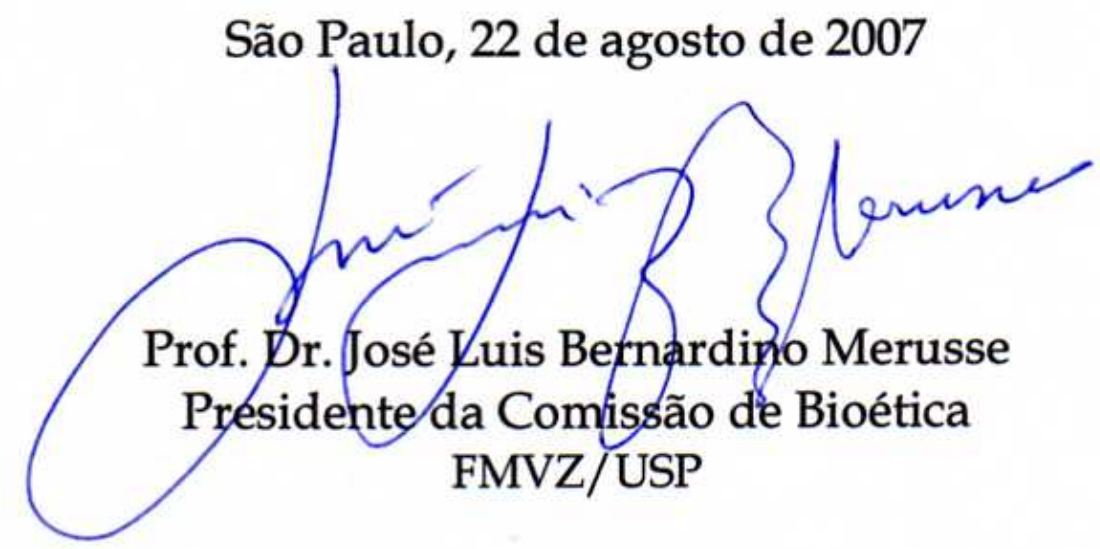




\section{FACULDADE DE MEDICINA VETERINÁRIA E ZOOTECNIA}

\section{CERTIFICADO}

Certificamos que o Projeto intitulado "Avaliação da estabilidade do modelo da cirrose hepática por tioacetamida em Ratas Wistar no período pós-indução", protocolado sob o $\mathrm{n}^{\circ} 1361 / 2008$, utilizando 15 (quinze) ratos, sob a responsabilidade do Prof. Dr. Francisco Hernandez Blazquez Javier, está de acordo com os princípios éticos de experimentação animal da Comissão de Bioética da Faculdade de Medicina Veterinária e Zootecnia da Universidade de São Paulo e foi aprovado "ad referendum".

(We certify that the Research "Evaluation of the stability of the hepatic cirrhosis model by thioacetamide in female Wistar Rats in the post-induction period", protocol number 1361/2008, utilizing 15 (fifteen) rats, under the responsibility Prof. Dr. Francisco Hernandez Blazquez Javier, agree with Ethical Principles in Animal Research adopted by Bioethic Commission of the School of Veterinary Medicine and Zootechny of University of São Paulo and was approved "ad referendum", meeting).

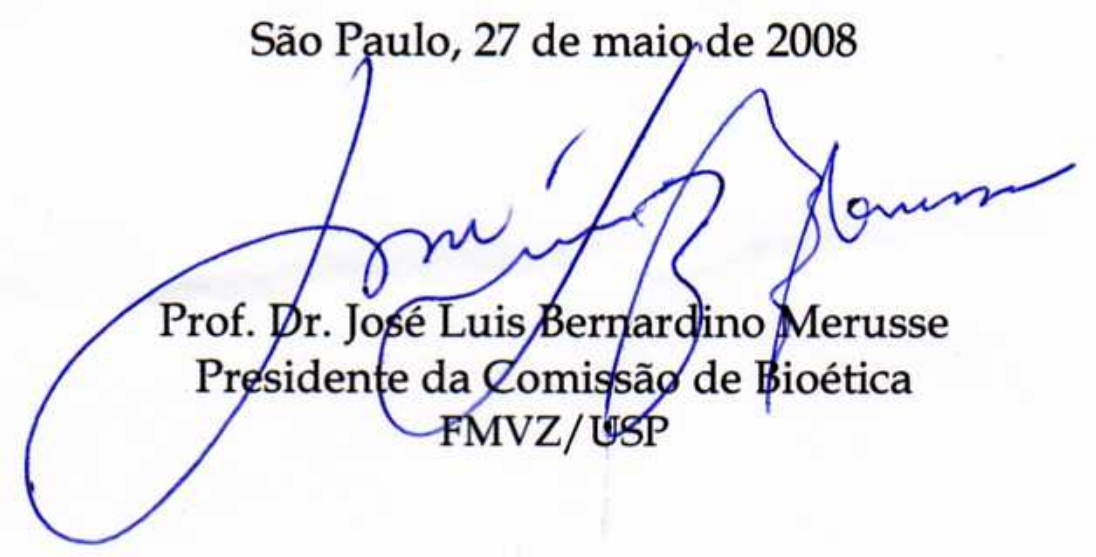




\section{FOLHA DE AVALIAÇÃO}

Nome: SILVA, Elizangela dos Anjos

Título: Avaliação morfológica e molecular pós-tratamento com os fatores hepatotróficos, da cirrose hepática induzida em ratas pela tioacetamida: análise a curto e longo prazo

Tese apresentada ao Programa de Pós-Graduação em Anatomia dos Animais Domésticos e Silvestres da Faculdade de Medicina Veterinária e Zootecnia da Universidade de São Paulo para obtenção do título de Doutor em Ciências

Data:

Banca Examinadora

Prof. Dr.

Assinatura:

Prof. Dr.

Assinatura:

Prof. Dr.

Assinatura:

Prof. Dr.

Assinatura:

Prof. Dr.

Assinatura:
Instituição:

Julgamento:

Instituição:

Julgamento:

Instituição:

Julgamento:

Instituição:

Julgamento:

Instituição:

Julgamento: 


\section{DEDICATÓRIA}

A Deus e a minha Mãezinha do Céu,

Por terem me concedido o dom da perseverança.

Meus queridos pais José Reis da Silva e Iracilda Donizete dos Anjos Silva "Nena",

Mesmo distantes, agradeço imensamente ao AMOR compartilhado, os conselhos e ensinamentos das conquistas dos objetivos com muita dignidade.

Meus irmãos "Clau e Suzi”,

Claudio Reis dos Anjos Silva e Suziane dos Anjos Silva pelo apoio participado.

Meus sobrinhos Alexander, Ígor e Vítor,

Meus três anjos me ensinaram que nas dificuldades o bom mesmo é olhar pra trás e lembrar que um dia eu também fui criança e que com o passar dos anos a gente se torna grande $e$ capaz o suficiente pra poder vencer e enfrentar tudo.

Aos meus avós, Germano Moreira dos Anjos (in memorian) e Regina Aparecida Botura dos Anjos, 
A meu Orientador Francisco Javier Hernandez-Blazquez,

Pela confiança depositada em mim. Aprendi muito com o senhor, principalmente a persistência, a ir atrás dos objetivos e das conquistas.

Meus queridos amigos Bruno Cogliati e Tereza Cristina Silva,

Agradeço imensamente pelas tantas horas de conversas, contribuições e ensinamentos passados em todo o momento no decorrer do desenvolvimento deste trabalho. Admiro muito vocês!

Aos grandes amigos Ana Paula da Silva, Cintia Maria Monteiro de Araújo, Janaína Marim Martins, Karla Patrícia Cardoso Araújo, Leandro Almeida Rui, Paulo Rogério de Oliveira, Tânia Cristina Silva, Thiago Pinheiro Arrais Alóia,

Agradeço por terem me ajudado e contribuído para o desenvolvimento deste trabalho. Vocês são excepcionais!

Waldmer Neylson Reccanello Facina,

A VOCÊ que me ensinou o verdadeiro sentido daquela velha frase... "No final tudo dá certo é só ter calma”... 
À Professora Maria Lúcia Zaidan Dagli,

Por ter permitido e confiado que eu utilizasse seu Laboratório para que parte de minha pesquisa pudesse ser realizada.

Aos grandes amigos do Laboratório de Anatomia, Histologia, Imuno-histoquímica e Biologia Molecular, Alexandro dos Santos Rodrigues, André Luiz Veiga Conrado, Fernanda Rodrigues Agreste, Gisele Saviani, Maurício de Rosa Trotta,

Estiveram sempre prontos a me aconselhar e a me ajudar.

Aos Professores do Setor de Anatomia, Antônio Augusto Coppi Maciel Ribeiro, José Roberto Kfoury Júnior, Maria Angélica Miglino, Romeu Rodrigues de Souza; Funcionários do Setor de Anatomia, Diogo Palermo, Edinaldo Ribas Farias, Jaqueline Martins de Santana, Maycon Barbosa da Silva, Ronaldo Agostinho da Silva,

Pela atenção dada durante todo o desenvolvimento da pesquisa quando precisei.

Aos colegas Pós-Graduandos do Setor de Patologia, Daniel Soares Sanches, Gregory Mennecier, Ivone Izabel Mackowiak da Fonseca, Kátia Cristina Kimura, Krishna Duro de Oliveira, Lucas Martins Chaible, Marcelo Monte Mor Rangel, Márcia Kazume Nagamine, Tarso Felipe Teixeira,

Por me receberem sempre tão bem no Laboratório de Patologia Experimental. 
Às técnicas do Laboratório de Patologia Experimental, Cyntia Esteves de Lima Villas Boas (in memorian), e Marguiti Isaura Soares Silva,

Por tantos ensinamentos, pelas longas horas de conversa e por serem tão carinhosas SEMPRE.

Agradeço a Dra. Claudia Madalena Cabrera Mori responsável pelo Biotério do Setor de Patologia,

Pela respeitosa disposição e simpatia em me ajudar na experimentação animal.

Aos funcionários do Biotério do Setor de Patologia Herculano, Idalina, Luiz, Mauro, Nelson, Rosiris,

Pelo valiosíssimo auxílio no manejo com os animais.

Às secretárias da Pós Graduação Cláudia Lima, Fátima Suzana, Joana Vasconcelos,

Por toda assistência oferecida.

Às Bibliotecárias da FMVZ-USP,

Pela diligência e competência com que avaliaram este trabalho.

À Fundação de Amparo à Pesquisa do Estado de São Paulo (FAPESP),

Pelo apoio financeiro que permitiu a realização deste trabalho e minha formação profissional. 
À Faculdade de Medicina Veterinária e Zootecnia da Universidade de São Paulo (FMVZ-USP), Pela minha formação profissional, a qual serei sempre honrada e grata.

Agradeço aos Animais,

Graças a eles esta pesquisa pode ser realizada.

Aos colegas e amigos,

Com um simples gesto fizeram parte deste trabalho.

Obrigada a todos!

“Todas as coisas devem ser feitas da forma mais simples possível, porém não mais simples que o possível”. 


\section{RESUMO}

SILVA, E. A. Avaliação morfológica e molecular pós-tratamento com os fatores hepatotróficos, da cirrose hepática induzida em ratas pela tioacetamida: análise a curto e longo prazo. [Morphological and molecular evaluation of liver cirrhosis induced by thioacetamide in rats after treatment with hepatotrophic factors: analysis of short and long term]. 2011. 180 f. Tese (Doutorado em Ciências) - Faculdade de Medicina Veterinária e Zootecnia, Universidade de São Paulo, São Paulo, 2011.

A cirrose hepática é um processo irreversível caracterizado pelo desequilíbrio entre a deposição e a degradação de componentes da matriz extracelular (MEC), acarretando disfunção hepatocelular e aumento da resistência ao fluxo sanguíneo, resultando em insuficiência hepática e na hipertensão portal. A cirrose em cães, muitas vezes é identificada nos estágios finais, já que o estágio inicial é assintomático. Em humanos, no estágio final da cirrose, o transplante é o único tratamento. Desta forma, a busca por tratamentos alternativos torna-se imprescindível. A administração de fatores hepatotróficos $(\mathrm{FH})$ tem sido estudada como uma alternativa de tratamento. Este estudo objetivou avaliar os efeitos dos FHs na cirrose hepática murina induzida pela tioacetamida (TAA), imediatamente após o tratamento, e 60 dias pós o seu término. 75 ratas Wistar foram subdivididas em quatro grupos; FH ( $\mathrm{n}=15)$ e o seu grupo controle $(\mathrm{CT}, \mathrm{n}=30)$, e $\mathrm{FH}^{+60 \mathrm{~d}}(\mathrm{n}=15)$ e seu controle $(\mathrm{CT}, \mathrm{n}=15)$; todos os animais foram induzidos à cirrose hepática pela administração TAA $(200 \mathrm{mg} / \mathrm{Kg})$, ip, 3 vezes/semana, por 14 semanas. Após a indução, dois grupos receberam a solução de FHs por 12 dias. Um foi eutanasiado imediatamente após o tratamento e o outro, 60 dias após o seu término. Foram realizadas análises bioquímica sérica e histopatológica; a quantificação do colágeno; avaliação da proliferação celular e da ativação das células estreladas. Ainda, foram avaliadas a expressão gênica de proteínas envolvidas na fibrogênese, como, colágeno tipo 1, TGFß-1, TIMP-1, MMP-2, MMP-13 e PLAU. Os resultados obtidos imediatamente após o tratamento mostraram que os FHs melhoraram as funções hepáticas, reduziram a deposição de colágeno e a ativação das células estreladas; alterando os mecanismos moleculares envolvidos na fibrogênese pela redução da expressão do colágeno tipo 1, aumento de TIMP-1, MMP-13 e PLAU. A maioria destes efeitos se manteve após o término do tratamento. Os resultados indicam que os FHs auxiliam no restabelecimento das funções e arquitetura hepáticas, atuando sobre os mecanismos de deposição e degradação da MEC, e que o tratamento com os FHs têm ação prolongada, não desaparecendo imediatamente após o tratamento. 
Palavras-chave: Fibrose. Cirrose Hepática Murina. Matriz Extracelular. Fatores Hepatotróficos. Tioacetamida. 


\begin{abstract}
SILVA, E. A. Morphological and molecular evaluation of liver cirrhosis induced by thioacetamide in rats after treatment with hepatotrophic factors: analysis of short and long term. [Avaliação morfológica e molecular pós-tratamento com os fatores hepatotróficos, da cirrose hepática induzida em ratas pela tioacetamida: análise a curto e longo prazo]. 2011. 180 f. Tese (Doutorado em Ciências) - Faculdade de Medicina Veterinária e Zootecnia, Universidade de São Paulo, São Paulo, 2011.
\end{abstract}

Hepatic cirrhosis is an irreversible process characterized by an imbalance between deposition and degradation of extracellular matrix components (ECM). This disease leads to hepatocellular dysfunction and increased resistance to blood flow resulting in liver failure and portal hypertension. The cirrhosis, in dogs, is often identified in the final stages whereas the early stage is asymptomatic. In humans, in the final stage of the cirrhosis, transplantation is the only treatment. Thus, the search for alternative treatments becomes essential. The administration of hepatotrophic factors (HF) has been studied as a treatment alternative. This study evaluated the effects of HFs in murine liver cirrhosis induced by thioacetamide (TAA) immediately after treatment, and 60 days after it ends. 75 female Wistar rats were distributed into four groups: $\mathrm{HF}(\mathrm{n}=15)$ and control group $(\mathrm{n}=30)$, and $\mathrm{HF}^{+60 \mathrm{~d}}(\mathrm{n}=15)$ and control group $(\mathrm{n}=15)$. Hepatic cirrhosis was induced in all animals by TAA administration $(200 \mathrm{mg} / \mathrm{kg})$, ip, 3 times a week for 14 weeks. After induction, two groups received the HFs solution for 12 days. One group was euthanized immediately after treatment and another group was euthanized 60 days after treatment. The following analyzes were performed: serum biochemistry, histopathologic, collagen quantification, cell proliferation, and stellate cells activation. In addition, the gene expression of proteins involved in fibrogenesis such as type 1 collagen, TGF $\beta-1$, TIMP-1, MMP-2, MMP-13, and PLAU was evaluated. The results found immediately after treatment showed that HFs improved liver function, and reduced collagen deposition and stellate cells activation. Alterations of the molecular mechanisms involved in fibrogenesis were observed by reducing the expression of collagen type 1 and increased expression of TIMP-1, MMP-13 and PLAU. Most of these effects remained after the treatment. The results indicate that the HFs assist in restoration of liver function and architecture, acting on the mechanisms of deposition and degradation of ECM. Furthermore, the treatment with HFs showed prolonged action, remaining during the post-treatment. 
Keywords: Fibrosis. Murine Liver Cirrhosis. Extracellular Matrix. Hepatotrophic factors. Thioacetamide. 


\section{SUMÁRIO}

1 INTRODUÇÃ

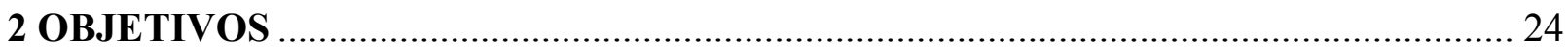

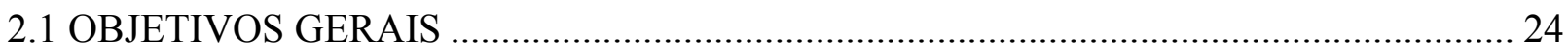

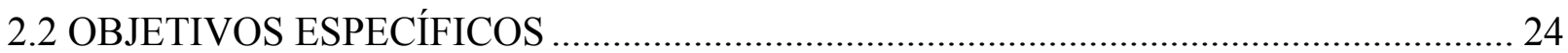

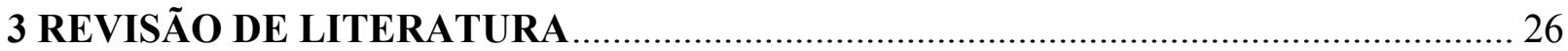

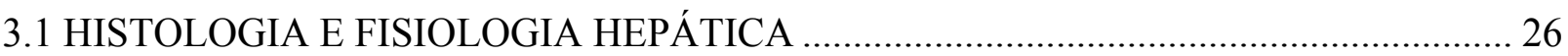

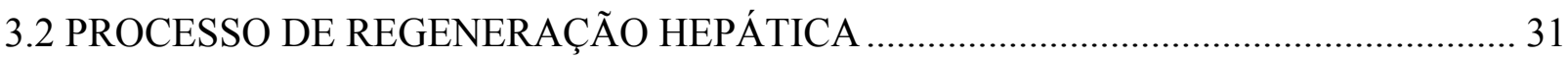

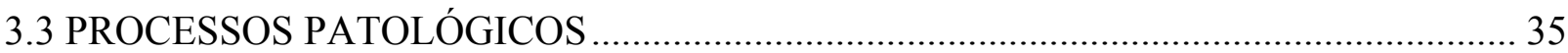

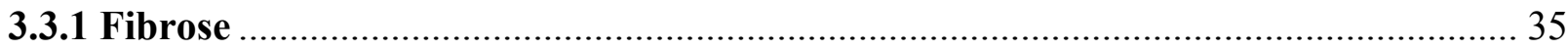

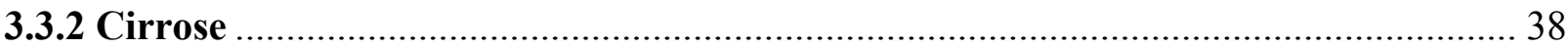

3.4 MATRIZ EXTRACELULAR E CIRROSE HEPÁTICA ……………………………......... 40

3.4.1 Mecanismos de ativação das células estreladas hepáticas ………………………….... 41

3.5 GENES MODULADORES DA MATRIZ EXTRACELULAR …………………………... 45

3.5.1 Colagenase 1 (MMP-1), colagenase 2 (MMP-8) e colagenase 3 (MMP-13) ............... 46

3.5.2 Gelatinase A (MMP-2) e gelatinase B (MMP-9) ………………………………….... 47

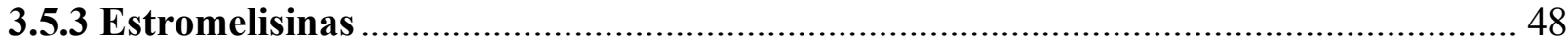

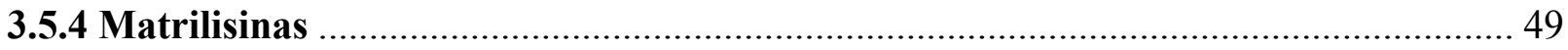

3.5.5 MMPs de canais de membrana (MT-MMPs) ………………………………........... 49

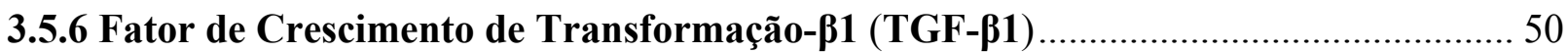

3.5.7 Ativador de Plasminogênio tipo Uroquinase (uPA ou PLAU) ……………………..... 51

3.5.8 Inibidores teciduais das metaloproteinases (TIMPs) …………………………...... 53

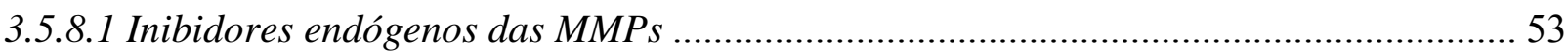

3.6 FATORES HEPATOTRÓFICOS EM FÍGADOS SADIOS E NO TRATAMENTO

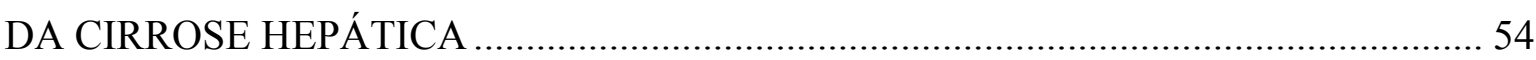

3.6.1 Malnutrição na cirrose hepática …………………………………………………….... 54 


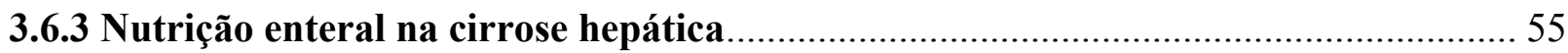

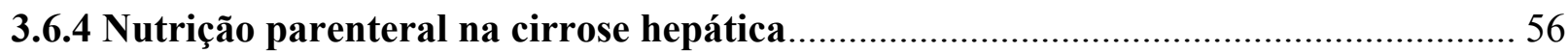

3.6.5 Fatores hepatotróficos em fígados sadios e com cirrose …...................................... 56

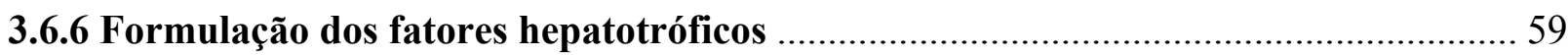

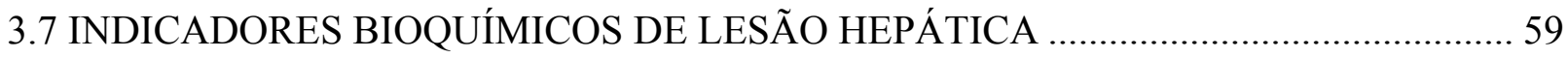

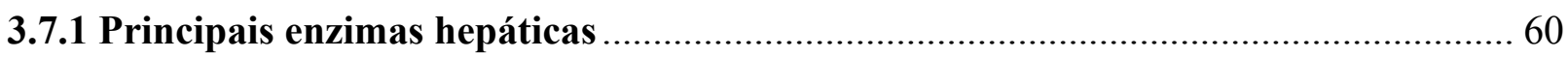

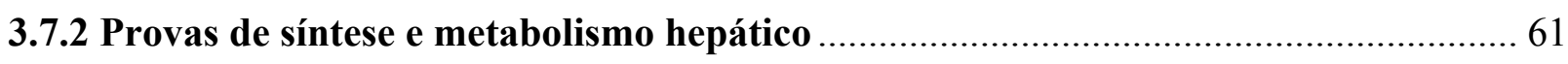

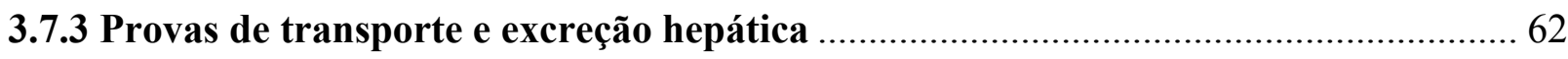

3.8 ANTÍGENO NUCLEAR DE PROLIFERAÇÃO CELULAR (PCNA) ................................ 63

3.9 MODELO EXPERIMENTAL DE CIRROSE HEPÁTICA PELA TIOACETAMIDA...... 66

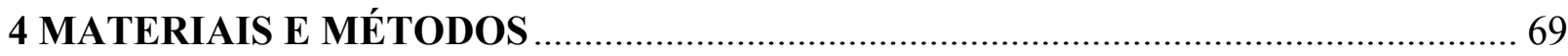

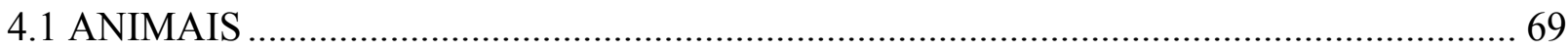

4.2 MODELO DE INDUÇÃO DA CIRROSE PELA ADMINISTRAÇÃO DA

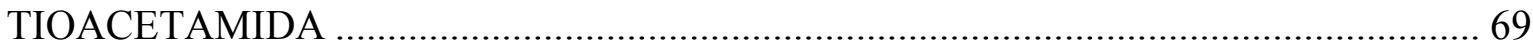

4.3 COMPOSIÇÃO E ADMINISTRAÇÃO DA SOLUÇÃO DOS FATORES

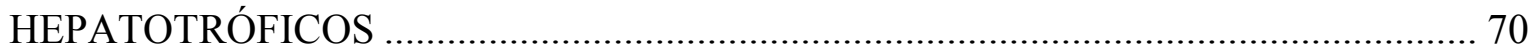

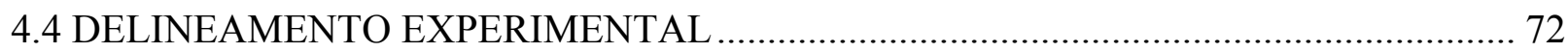

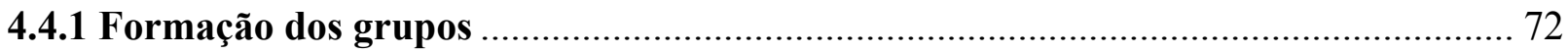

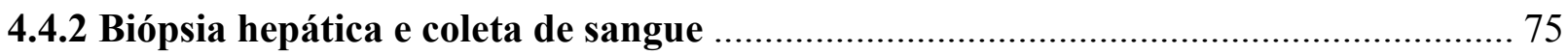

4.4.3 Avaliação dos sinais clínicos e acompanhamento da mortalidade ............................ 76

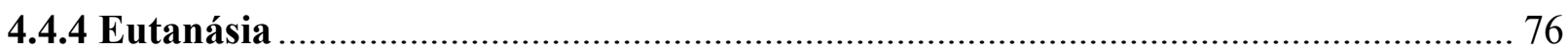

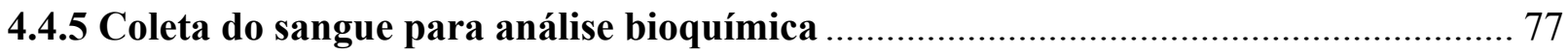

4.5 FIXAÇÃO E PROCESSAMENTO DO MATERIAL BIOLÓGICO ................................. 78

4.6 BIOMETRIA - CÁLCULO DOS ÍNDICES RELATIVOS ............................................. 79

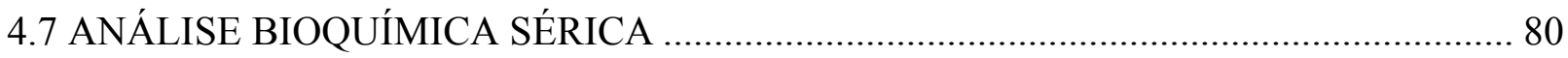

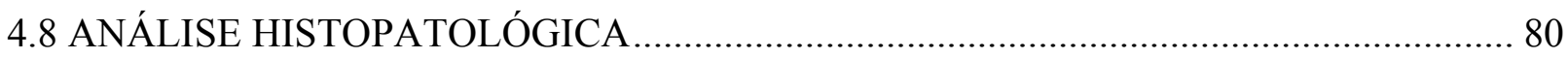


4.8.1 Avaliação das alterações celulares 80

4.8.2 Avaliação das alterações teciduais 83

4.8.2.1 Determinação do estadiamento da cirrose hepática e índice de atividade histológica.

4.8.2.2 Avaliação da proliferação dos ductos 85

4.8.3 Análise morfométrica do colágeno 85

4.8.4 Imunofluorescência para os colágenos tipo 1 e 3 86

4.8.5 Imunofluorescência para $\alpha$-SMA 87

4.8.6 Imuno-histoquímica para PCNA 88

4.9 AVALIAÇÃO DA EXPRESSÃO GÊNICA POR PCR EM TEMPO REAL 89

4.9.1 Extração do RNA. 89

4.9.2 Determinação da integridade e quantificação do RNA total 90

4.9.3 Transcrição reversa - obtenção do DNA complementar (cDNA). 90

4.9.4 Assays (primers) e probes 91

4.9.5 Método de pré-amplificação gênica 92

4.9.6 Quantificação da expressão gênica por PCR em tempo real. 92

4.10 ANÁLISE ESTATÍSTICA 93

5 RESULTADOS 94

5.1 OS SINAIS CLÍNICOS DECORRENTES DA ADMINISTRAÇÃO DA TAA E/OU DO TRATAMENTO COM OS FHS NÃO FORAM OBSERVADOS EM TODOS OS ANIMAIS E DESAPARECERAM PÓS-ADMINISTRAÇÃO 94

5.2 RESULTADOS DOS ANIMAIS CIRRÓTICOS TRATADOS (FH) OU NÃO (CT) COM OS FHS POR 12 DIAS E EUTANASIADOS IMEDIATAMENTE APÓS O TRATAMENTO 95

5.2.1 A administração da TAA e/ou o tratamento com os FHs não provocaram aumento na taxa de mortalidade dos animais. 95

5.2.2 O tratamento com os FHs reduziu o peso médio dos animais submetidos à indução com a TAA 
5.2.3 O tratamento com os FHs aumentou a densidade do fígado 96

5.2.4 O tratamento com os FHs melhorou as funções hepáticas 99

5.2.5 O tratamento com os FHs aumentou a deposição de mucopolissacarídeos ácidos e reduziu o acúmulo de glicogênio

5.2.6 O tratamento não alterou a atividade histológica e o estadiamento da fibrose/cirrose hepáticas 104

5.2.7 O tratamento não alterou a proliferação dos ductos hepáticos. 106

5.2.8 O tratamento reduziu a deposição de colágeno 107

5.2.9 O tratamento reduziu a ativação das células estreladas 109

5.2.10 O tratamento não reduziu a proliferação dos hepatócitos. 110

5.2.11 O tratamento alterou os mecanismos moleculares envolvidos na fibrogênese hepática

5.3 RESULTADOS DOS ANIMAIS CIRRÓTICOS TRATADOS $\left(\mathrm{FH}^{+60 \mathrm{~d}}\right)$ OU NÃO

(CT) COM OS FHS POR 12 DIAS E EUTANASIADOS 60 DIAS PÓSTRATAMENTO 114

5.3.1 A administração da TAA, o tratamento com os FHs e/ou o período de 60 dias pós-tratamento não provocaram aumento na taxa de mortalidade dos animais 114

5.3.2 O peso médio dos animais não se alterou 60 dias pós-tratamento 114

5.3.3 A densidade do fígado reduziu 60 dias pós-tratamento 115

5.3.4 Os efeitos benéficos na função hepática se mantiveram pós-tratamento 118

5.3.5 A deposição de mucopolissacarídeos ácidos e de glicogênio aumentou 60 dias pós-tratamento

5.3.6 A atividade histológica e o estadiamento da fibrose/cirrose hepáticas não se alteraram pós-tratamento

5.3.7 A proliferação dos ductos hepáticos não sofreu alteração pós-tratamento.

5.3.8 Os efeitos do tratamento sobre a deposição do colágeno intralobular permaneceram 60 dias após o seu término 
5.3.10 A proliferação dos hepatócitos reduziu após o tratamento com os FHs

5.3.11 Os mecanismos de fibrólise permaneceram alterados 60 dias após o término do tratamento

6 DISCUSSÃO 134

6.1 DISCUSSÃO DOS RESULTADOS OBSERVADOS IMEDIATAMENTE APÓS TRATAMENTO COM OS FATORES HEPATOTRÓFICOS - GRUPO FH E SEU CONTROLE (CT)

6.2 DISCUSSÃO DOS RESULTADOS OBSERVADOS 60 DIAS PÓSTRATAMENTO COM OS FATORES HEPATOTRÓFICOS - GRUPO FH ${ }^{+60 \mathrm{~d}}$

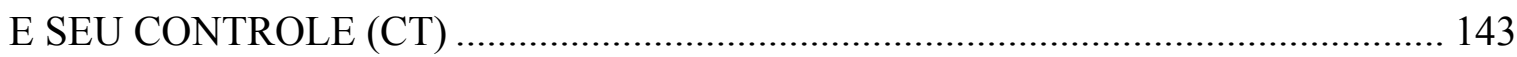

7 CONCLUSÕES

7.1 CONCLUSÕES DOS RESULTADOS OBSERVADOS IMEDIATAMENTE APÓS TRATAMENTO COM OS FATORES HEPATOTRÓFICOS - GRUPO FH E SEU CONTROLE (CT)

7.2 CONCLUSÕES DOS RESULTADOS OBSERVADOS 60 DIAS PÓSTRATAMENTO COM OS FATORES HEPATOTRÓFICOS - GRUPO FH ${ }^{+60 \mathrm{~d}}$ E SEU CONTROLE (CT) 150

REFERÊNCIAS 151 


\section{INTRODUÇÃO}

Uma das enfermidades que mais acomete o fígado em seres humanos é a cirrose (ROBBINS; COTRAN; KUMAR, 1996), e caracteriza-se por apresentar modificações nas unidades histológicas básicas - os lóbulos hepáticos; principalmente por formação de nódulos de regeneração (ANTHONY et al., 1977) e desarranjo na disposição cordonal dos hepatócitos, formando ilhas irregulares de células hepáticas, circundada por grande quantidade de tecido conjuntivo (MACLACHLAN; CULLEN, 1998).

Refere-se a um crescimento progressivo e difuso de tecido conjuntivo fibroso; o que conduz o fígado a apresentar um aspecto nodular, levando a interrupção da arquitetura geral normal deste órgão (HEIDELBAUGH; BRUDERLY, 2006); com a progressão da cirrose hepática, eventos secundários podem ocorrer, como, desenvolvimento da pressão portal, hemorragia visceral, encefalopatia hepática, síndrome hepatorrenal, e peritonite bacteriana espontânea (HEIDELBAUGH; SHERBONDY, 2006).

As causas da cirrose geralmente podem ser identificadas pela história do paciente combinada com investigação sorológica e histológica (FOUTCH et al., 1988; PIROVINO et al., 1988; TANGERMAN; MEUWESE-ARENDS; JANSEN, 1994). A doença hepática alcoólica e a hepatite $\mathrm{C}$ são as causas mais comuns nos países desenvolvidos, enquanto a hepatite B é a causa predominante na maior parte da Ásia e da África subsaariana. O conhecimento da causa também permite a discussão de medidas preventivas, por exemplo, com membros da família de pacientes com cirrose alcoólica ou hepatite viral crônica, e consideração (genética) de teste e aconselhamento preventivo para familiares de pacientes com doenças genéticas, como a hemocromatose e doença de Wilson. Estudos epidemiológicos têm identificado uma série de fatores que contribuem para o risco do desenvolvimento da cirrose.

O consumo regular de álcool (moderado), idade maior que 50 anos e o sexo masculino são exemplos que aumentam o risco de cirrose (POYNARD; BEDOSSA; OPOLON, 1997; BELLENTANI et al., 1997, 1999) em pacientes com hepatite crônica C, o envelhecimento, obesidade, resistência à insulina ou diabetes tipo 2, hipertensão, hiperlipidemia (todos característicos da síndrome metabólica) na esteato-hepatite não alcoólica (CLARK, 2006; FARRELL; LARTER, 2006). Aproximadamente 40\% dos pacientes com cirrose são 
assintomáticos, e as condições frequentemente são descobertas durante um exame de rotina através de estudos laboratoriais e radiográficos, ou mesmo a autópsia.

A cirrose e a falha hepática crônica, juntas, foram a décima segunda causa mais comum da morte nos Estados Unidos em 2002; 27.257 mortes, com alto predomínio masculino (HEIDELBAUGH; BRUDERLY, 2006). Em agosto de 2005, havia 17.935 pessoas com cirrose (de várias etiologias), a espera de transplante hepático; sendo que o maior índice de mortalidade em pacientes com doença hepática é de causa alcoólica, quando comparado com outras formas de cirrose (HEIDELBAUGH; BRUDERLY, 2006).

A hepatite crônica, também vem sendo comumente identificada nas diversas raças de cães (STROMBECK; GRIBBLE, 1978; ANDERSSON; SEVELIUS, 1991; SEVELIUS, 1995; FUENTEALBA et al., 1997). A hepatite crônica em cães não é uma doença, mas um grupo diverso de doenças, resultando em um quadro patológico clínico e clínico comum; vírus, leptospirose, outros agentes infecciosos, drogas, fatores hereditários, e auto-imunidade têm sido associadas com doença hepática levando à hepatite crônica em cães (DILLMACKY, 1995; ROTHUIZEN, 2004).

$\mathrm{Na}$ maioria dos casos, a etiologia da hepatite canina é obscura, contudo, causas conhecidas de hepatite canina são as infecciosas, ocasionados pelo adenovírus canino tipo 1 (CAV-1), tóxicos (aflatoxina), e metabólicos (acúmulo de cobre) (BOOMKENS et al., 2004). É considerada uma doença frustrante para o veterinário, devido aos poucos dados publicados referente aos medicamentos utilizados para tratar tal patologia, progredindo inevitavelmente para a cirrose, com mau prognóstico (WATSON, 2004).

Várias pesquisas e tratamentos têm sido propostos para tratar este processo patológico, a utilização de substâncias com efeito hepatotrófico, dentre os quais podemos citar vitaminas, aminoácidos, sais minerais, insulina, glucagon, triiodotironina e glicose (PARRA, 1982; PARRA et al., 1992, 1994, 1995a; 1995b; GUERRA et al., 2009); e vários fatores com ação regulatória, como as citocinas (IL-6, IL-1a, e TNF- $\alpha$ ) (BLANC et al., 1992; GOMEZLECHON et al., 1996; MICHALOPOULOS; DeFRANCES, 1997); a terapia gênica ativadora do plasminogênio tipo uroquinase (SALGADO et al., 2000); e a utilização da proteína ALR, aumentadora da regeneração hepática (DAYOUB et al., 2006).

Também tem sido utilizada a hepatectomia parcial (SAAD, 1972, 1975; HASHIMOTO et al., 1998; BARATTA et al., 1996; FAUSTO; LAIRD; WEBBER, 1995), ou ainda esta, associada à inibição da enzima conversora de angiotensina pelo lisinopril 
(RAMALHO et al., 2001). Oxigenação hiperbárica (OZDOGAN et al., 2005). Transplante hepático; emprego de células tronco hepática (TARLÁ et al., 2006a).

Parra et al. (1992) testaram uma solução de fatores hepatotróficos em ratas com fígados normais, baseada em uma solução hospitalar de nutrição parenteral, com aminoácidos, vitaminas e sais minerais; administraram-na por via intraperitoneal (portal), foi observado aumento de 34,5\% da massa hepática. O mesmo grupo adicionou hormônios (insulina, glucagon e triiodotironina) a solução, ocasionando um aumento de massa ainda maior, 67\%, principalmente pela proliferação celular. Em acréscimo, houve diminuição da porção fibrosa da matriz extracelular, sendo cogitada possível ação fibrinolítica (PARRA et al., 1994, 1995b). Quando o tratamento com fatores hepatotróficos com adição de hormônios foi administrado a ratos hepatectomizados, houve aumento da proliferação de $17 \%$ e diminuição da proporção de colágeno hepático.

Corpechot et al. (2002); Jesus, Waitzberg e Campos (2000); Kaibori et al. (1997) e Kalil, Sperb e Lichtenfels (1998) comentaram que a descoberta dos fatores hepatotróficos abriu perspectivas de intervenção direta no processo de regeneração do fígado. Estes fatores influenciam o crescimento e trofismo hepático através de substâncias externas; sendo um recurso auxiliar na superação das limitações inerentes ao tratamento cirúrgico. Michalopoulos e DeFrances (1997); Usami et al. (1996); Parra et al. (1994; 1995a; 1995b) citam que diversas substâncias foram testadas para verificar sua influência na regeneração hepática; dentre elas, glicose, aminoácidos, lipídios, soluções de nucleotídeos e vários tipos de hormônios.

Atualmente, o restabelecimento das funções normais do fígado cirrótico sem a hepatectomia vem se mostrando uma alternativa de tratamento menos traumática e mais eficaz. A administração de fatores de crescimento, em animais e em pacientes com doença hepática grave, como a cirrose, até o presente momento, produziu, em muitos casos, efeitos benéficos aos pacientes aumentando a sobrevida e prevenindo a falência deste órgão (GORLA JR, 2001; KAIBORI et al., 2002).

Guerra et al. (2009) e Pereira et al. (2003) recentemente, investigando o efeito do tratamento com fatores hepatotróficos, respectivamente em fígados cirróticos e fibróticos de ratas Wistar, observaram que estes fatores mostraram ser efetivos na interrupção da evolução da cirrose ou fibrose. Os autores relataram evidente recuperação da arquitetura hepática, redução da quantidade global de fibras colágenas depositada no parênquima hepático, e diminuição do número de nódulos regenerativos. Os estudos moleculares de Guerra et al. (2009) mostraram redução na expressão de genes pro-fibróticos, como colágeno $\alpha 1$ e TGF $\beta 1$, 
que atuam direta ou indiretamente na deposição da matriz extracelular, e na ativação de células estreladas hepáticas. As células estreladas têm localização perisinusoidal, são responsáveis pela produção de fatores de crescimento, citocinas, prostaglandinas e outras substâncias bioativas (BRANDÃO et al., 2006).

Sabemos que o tratamento com fatores hepatotróficos por um curto período de tempo (10-12 dias) traz efeitos benéficos na arquitetura e condição geral do fígado de ratos com cirrose hepática, tendo sido observada a reversão de vários aspectos do quadro cirrótico. Porém, os animais tratados não foram mantidos vivos para verificar como o quadro histológico e funcional hepático continuaria evoluindo após os primeiros dez dias de tratamento. Assim, a permanência ou eficácia a longo prazo do tratamento ainda não foi testada, restando saber se a melhora do quadro cirrótico estaciona, evolui sozinho para uma condição melhor, ou se há recidiva com o tempo, após o término do tratamento. Esta é uma pergunta importante e essencial antes de se pensar em futuros testes clínicos em veterinária.

Desta forma, este estudo avaliou os efeitos do tratamento com os fatores hepatotróficos, a curto e a longo prazo, após o desenvolvimento do processo patológico no fígado de ratas submetidas ao modelo de cirrose hepática induzido pela tioacetamida por 14 semanas. 


\section{OBJETIVOS}

Os objetivos serão divididos em gerais e específicos.

\subsection{OBJETIVOS GERAIS}

Avaliar os efeitos sobre a cirrose hepática, induzida em ratas Wistar, pela administração da tioacetamida, imediatamente após o tratamento com os fatores hepatotróficos (FHs).

Avaliar se os efeitos do tratamento com fatores hepatotróficos (FHs), sobre a cirrose hepática induzida em ratas Wistar, pela administração da tioacetamida, se mantiveram 60 após o tratamento.

\subsection{OBJETIVOS ESPECÍFICOS}

1. Avaliar, nos dois períodos experimentais, o desenvolvimento da cirrose durante e após o tratamento com os FHs;

2. Verificar, nos dois períodos experimentais, os efeitos sobre a função bioquímica hepática e no desenvolvimento de lesões necro-inflamatórias, durante e após o tratamento; 
3. Avaliar, nos dois períodos experimentais, os efeitos sobre a deposição do colágeno;

4. Avaliar, nos dois períodos experimentais, os efeitos sobre a ativação das células estreladas;

5. Avaliar, nos dois períodos experimentais, os efeitos do tratamento sobre a proliferação dos hepatócitos;

6. Avaliar, nos dois períodos experimentais, os efeitos do tratamento sobre a expressão dos principais genes envolvidos nos mecanismos de síntese e degradação da matriz extracelular. 


\section{REVISÃO DE LITERATURA}

Os tópicos relacionados à revisão de literatura estão listados abaixo.

\subsection{HISTOLOGIA E FISIOLOGIA HEPÁTICA}

O fígado é composto por $60 \%$ de células parenquimatosas (hepatócitos) e células não parenquimatosas (células de Kupffer, colangiócitos, células endoteliais, estreladas hepáticas e ovais). Basicamente a estrutura do parênquima hepático está organizada em lobos que contém uma veia central, circundada por seis espaços portais (RAO, 2003; TARLÁ et al., 2006a).

O hepatócito é a célula mais multifuncional do organismo, de forma poliédrica com 6 ou mais faces e medem de 20 a $30 \mu \mathrm{m}$ de diâmetro. Esta célula apresenta um núcleo central, arredondado, com um ou dois nucléolos bem evidentes. Os retículos endoplasmáticos são bem evidentes. Cada lóbulo é uma massa poliédrica de tecido hepático de mais ou menos 0,7 por 2 mm de tamanho. Nos lóbulos os hepatócitos se dispõem em cordões orientados radialmente. Os cordões são constituídos por células dispostas em uma só camada que é perfurada e, frequentemente, anastomosam-se, resultando num labirinto complexo, que dá ao lóbulo hepático um aspecto esponjoso (ROUILLER, 1964; GUYTON; HALL, 2002; GARTNER; HIAT, 2003; JUNQUEIRA; CARNEIRO, 2004) (Figura 1). 


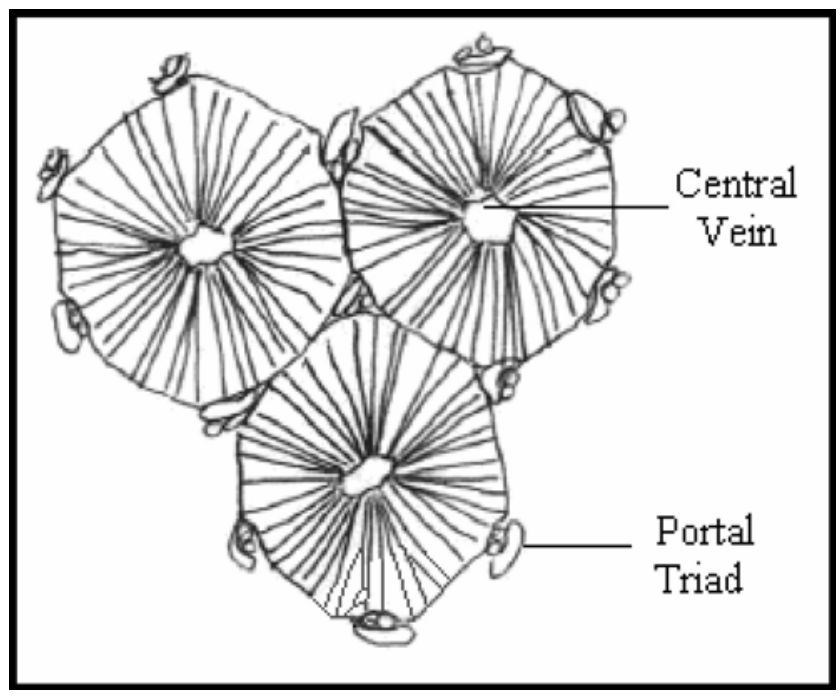

Fonte: (TARLÁ et al., 2006a)

Figura 1 - Ilustração esquemática de um lóbulo hepático

O espaço porta consiste de uma veia, uma artéria hepática e um ducto biliar que drenam espaços entre os hepatócitos, os sinusóides hepáticos que são formados por células endoteliais sinusoidais. As células de Kupffer são encontradas nos sinusóides e as células estreladas estão localizadas no espaço perisinusoidal (RAO, 2003; TARLÁ et al., 2006a).

Os capilares sanguíneos localizados entre os cordões de células hepáticas são denominados sinusóides, ou seja, capilares hepáticos de paredes revestidas por células endoteliais típicas têm a função de levar sangue rico em nutrientes e oxigênio para o parênquima hepático. Os capilares sinusóides desembocam na veia centrolobular, no centro do lóbulo e medem entre 10 e $30 \mu \mathrm{m}$ de diâmetro. Seu endotélio é fenestrado e se assenta sobre uma membrana basal descontínua. Além disso, a junção entre as células endoteliais contíguas é incompleta e há separações de 0,1 a $0,5 \mu \mathrm{m}$. Entre os sinusóides hepáticos, estão localizadas células conhecidas como células de Kupffer; macrófagos característicos observados somente entre os sinusóides hepáticos (GUYTON; HALL, 2002; CORMACK, 2003; GARTNER; HIAT, 2003; HIB, 2003; JUNQUEIRA; CARNEIRO, 2004) (Figura 2). 

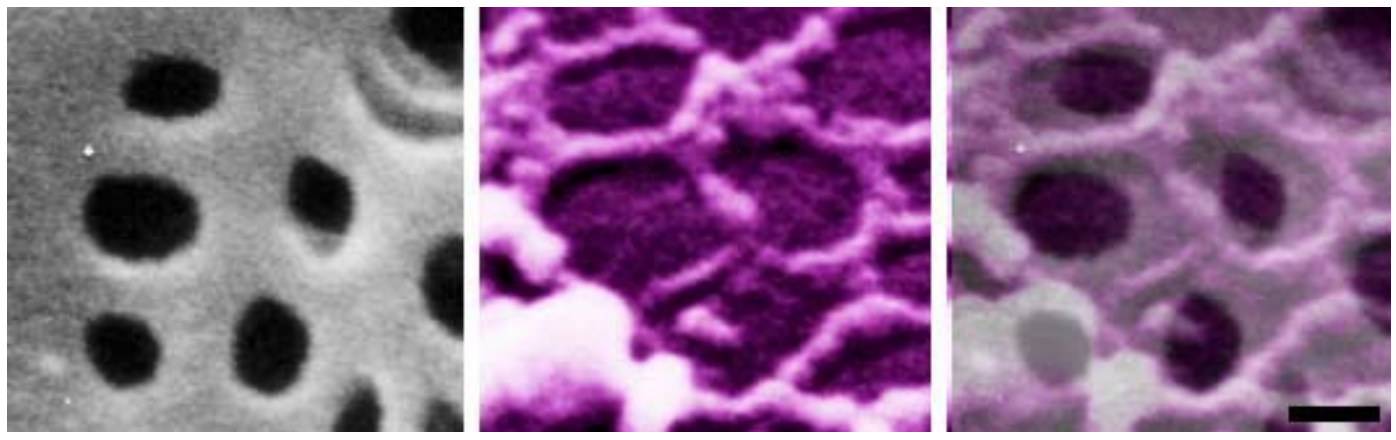

Fonte: (BRAET; WISSE, 2002)

Figura 2 - Micrografia eletrônica da célula endotelial sinusoidal

As células de Kupffer possuem núcleo oval, grande, e nucléolo evidente, apresentam intensa atividade fagocitária, tem a função de fagocitar hemácias em via de desintegração, digerir hemoglobina e produzir bilirrubina. Estas células apresentam grande quantidade de lisossomas que contêm no seu interior as enzimas necessárias para a digestão intracelular. Essas células reconhecem e endocitam pelo menos $99 \%$ dos microorganismos do sangue da veia porta (GUYTON; HALL, 2002; CORMACK, 2003; GARTNER; HIAT, 2003; JUNQUEIRA; CARNEIRO, 2004).

No estreito espaço que separa a parede dos capilares sinusóides aos hepatócitos, se encontra o espaço de Disse, que contém células armazenadoras de lipídios, com forma estrelada. São as células estreladas hepáticas (células de estoque de gordura ou células de Ito) que armazenam vitamina $\mathrm{A}$ em suas gotículas lipídicas. Em resposta a lesão hepática, estas células perisinusoidais podem proliferar, tornam-se contráteis e produzem MEC em excesso (GUYTON; HALL, 2002; CORMACK, 2003; GARTNER; HIAT, 2003; JUNQUEIRA; CARNEIRO, 2004). A fibrose hepática é caracterizada pela ativação das células estreladas hepáticas, uma resposta comum a injúria hepática crônica (FRIEDMAN, 2008a) (Figura 3). 


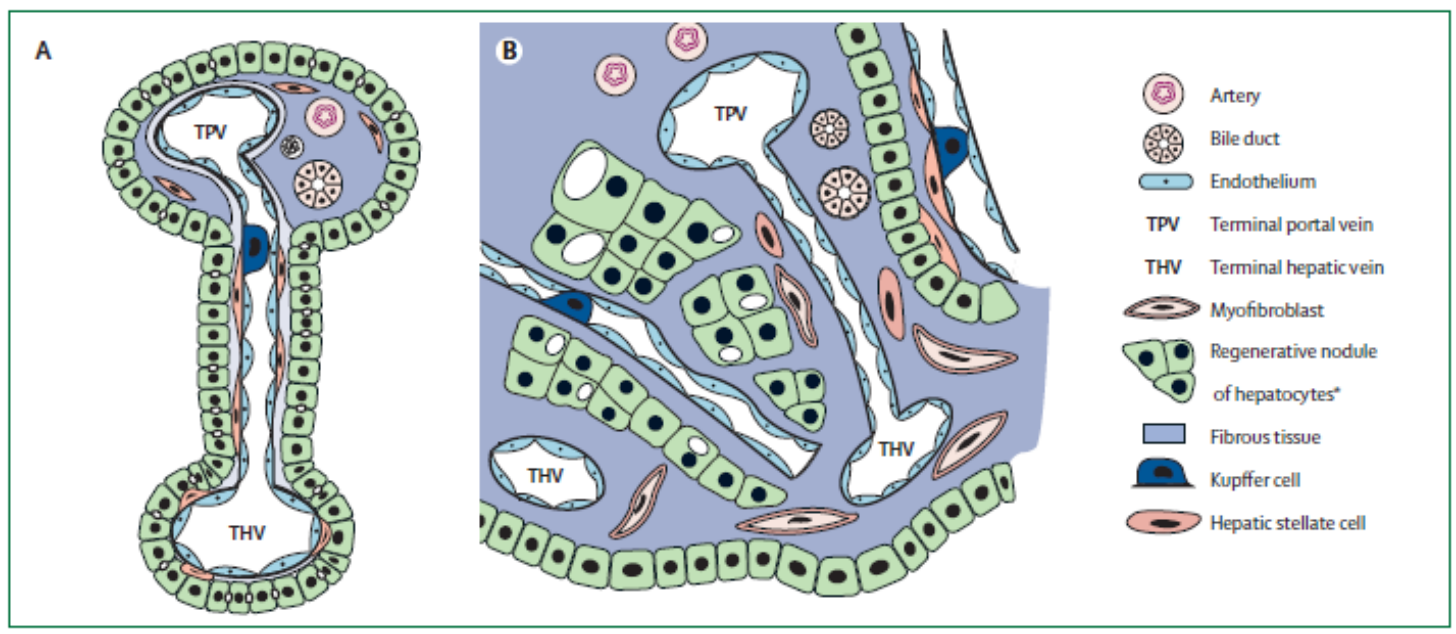

Fonte: (SCHUPPAN; AFDHAL, 2008)

Figura 3 - Em A, Fígado saudável; B, Fígado com cirrose

O fígado recebe sangue pela veia porta $(70 \%)$ e uma porção menor pelas artérias hepáticas. Pela veia porta chega ao fígado todo material absorvido pelo intestino, com exceção dos lipídios que é transportado por via linfática. Os espaços de Disse conectam-se com os vasos linfáticos nos septos interlobulares, assim, o excesso de líquido nesses espaços é removido por esses vasos (GUYTON; HALL, 2002; CORMACK, 2003; GARTNER; HIAT, 2003; JUNQUEIRA; CARNEIRO, 2004).

A bile secretada pelos hepatócitos circula pelos canalículos biliares até a periferia do lóbulo hepático, ao chegar à periferia do lóbulo, a bile ingressa em ductos excretores curtos, conhecidos como ductos (ou canais) de Hering. Estes desembocam em ductos maiores, chamados ductos biliares perilobulares, os quais, do mesmo modo que as arteríolas e as vênulas terminais se dispõem entre as faces laterais dos lóbulos. Após atravessar a lâmina terminal dos espaços porta, os ductos biliares perilobulares desembocam perpendicularmente nos ductos biliares interlobulares destes espaços (HIB, 2003).

Outro tipo celular são as células tronco hepáticas que produzem células progenitoras denominadas células ovais no fígado adulto de humanos e animais (PETERSEN; ZAJAC; MICHALOPOULOS, 1998). Morfologicamente, estas células medem aproximadamente 10 $\mu \mathrm{m}$ e têm uma grande relação núcleo/citoplasmático, apresentam núcleo com forma bem oval (por isso seu nome) (FARBER, 1956). Estas células são ativadas por hepatocarcinogênicos ou por injúria química aos hepatócitos e podem se diferenciar para formar hepatócitos e colangiócitos (ALISON et al., 1996, 1997, 1998; PAKU et al., 2001). Tem sido relatado que 
as células ovais derivam dos canais de Hering, dos dúctulos biliares ou células periductais em diferentes modelos animais (PAKU et al., 2001; THEISE et al., 1999; YAVORKOVSKY et al., 1995). Sell (2001) postulou que as células ovais, ativadas por álcool alil ou em modelos suplementados com uma dieta de etionina deficiente de colina originam células progenitoras periductais, que podem ser derivadas da medula óssea.

O fígado também possui outro tipo celular, as pit cell, são linfócitos $\mathrm{T}$ citotóxicos residentes que se localizam nos sinusóides e são identificados por inclusões citoplasmáticas denominadas pits (LE COUTEUR et al., 2008). Em holandês, esse termo é utilizado para designar grânulos citoplasmáticos por lembrar "caroços" em uma uva. As pit cells são células natural killer (NK) específicas do fígado com características morfológicas, funcionais e imunofenotípicas diferentes das células NK do sangue. A frequência dessas células no tecido hepático é de 1 pit cell para 10 células de Kupffer e, assim como estas, as pit cells são mais numerosas na região periportal do que na região pericentral do lóbulo hepático (LUO et al., 2000). As pit cells aderem às células endoteliais e às células de Kupffer e migram pela superfície dessas células estendendo seus pseudópodos bem desenvolvidos (NAKATANI et al., 2004).

A matriz extracelular (MEC) hepática que ocupa menos que 3\% da área do fígado têm a função de dar suporte às células. $O$ colágeno é a proteína principal da matriz extracelular, com colágeno tipo I, III e V, localizado na área portal e veia central, e colágeno tipo IV, que junto com a laminina e a entactina-nidogen originam a membrana basal (BEDOSSA; PARADIS, 2003). Outras moléculas incluem as glicoproteínas (laminina, fibronectina, tenascina, nidogen e SPARC - proteína secretada acídica rica em cisteína) e proteoglicanas (heparam, dermatam, sulfato de condroitina, perlecam, ácido hialurônico e decorina). A contínua rede de MEC em torno das células torna possível o estoque e a transmissão de sinais pelas ligações e liberações de fatores de crescimento, hormônios, enzimas e citocinas (RAO, 2003).

O fígado exerce um papel importante na manutenção da homeostase metabólica, através do processamento de aminoácidos, formação e excreção da bile, síntese de lipídeos e das vitaminas provenientes da alimentação, dos carboidratos, da secreção de lipoproteínas plasmáticas, no controle do metabolismo do colesterol, formação de uréia e albumina sérica, dos fatores de coagulação, das enzimas, algumas proteínas e pela detoxificação de drogas e toxinas; na produção de fatores de coagulação, e estoque de glicogênio (HEIDELBAUGH; BRUDERLY, 2006). 


\subsection{PROCESSO DE REGENERAÇÃO HEPÁTICA}

O fígado possui um ritmo lento de renovação celular, mas apresenta uma grande capacidade de regeneração (JUNQUEIRA; CARNEIRO, 2004). Ele responde a injúrias teciduais (agentes químicos, biológicos ou hepatectomia parcial) pela entrada de hepatócitos quiescentes no ciclo celular (TORRES et al., 1999) e, assim, as células progridem sincronicamente para restaurar o volume e a função hepática (KATO et al., 2005). Esta propriedade do fígado, de regular seu próprio tamanho e crescimento, surge do seu papel central em funções metabólicas essenciais à vida (ARIAS et al., 1994).

Embora seja denominada regeneração, o processo que ocorre após a retirada de uma porção do fígado se dá por crescimento compensatório da porção remanescente por proliferação celular; ocorre um processo de hiperplasia das células quiescentes, visto que os lobos seccionados não são recuperados (FAUSTO; CAMPBELL; RIEHLE, 2006; MYRONOVYCH et al., 2008).

A proporção do tamanho do fígado em relação à massa corporal é constante. Nos casos de ressecção hepática, a resposta regenerativa do órgão é proporcional à massa hepática removida. Em transplantes de fígado de um doador menor para um maior, ou o contrário, há reestruturação do órgão até atingir a proporção ideal (MICHALOPOULOS; DEFRANCES, 1997). Isto também acontece na hipertrofia ou hiperplasia induzida por drogas. A retirada do estímulo leva a apoptose de hepatócitos até que a massa normal seja restaurada (FAUSTO, 2000).

Nos casos de hepatectomia parcial ou injúria leve, há recuperação completa do parênquima hepático, pois, diferentemente dos casos de injúria crônica com fibrose, a trama de reticulina do fígado permanece intacta. Quando essa rede é preservada, a proliferação de células parenquimais e não parenquimais procede ordenadamente, mantendo a proporção ideal entre células e matriz extracelular. Como os hepatócitos replicam primeiro, os componentes da matriz precisam ser sintetizados para manter a arquitetura hepática normal e prover novas estruturas vasculares (ARIAS et al., 1994). 
Em casos onde a proliferação dos hepatócitos é inibida, existem células que são capazes de se diferenciarem em tecido hepático, estas, são células tronco do próprio tecido hepático (célula oval) que atua como um precursor bipotencial, contribuindo para o restauro do fígado principalmente quando os hepatócitos se encontram impossibilitados de proliferar (TARLÁ et al., 2006b).

Estas células demonstram uma origem celular comum (clonal), habilidade para autorenovação, potencial proliferativo, diferenciação, capacidade para regenerar tecidos após injúria, presença de marcadores de não diferenciação celular e de linhagem específica (POTTEN; LOFFLER, 1990). Outro precursor é a célula tronco de origem hematopoética, que também participa do processo regenerativo, originando células da linhagem hepatocítica e colangiócitos, assim como as células ovais (TARLÁ et al., 2006b).

A regeneração hepática pode ser dividida em três fases, iniciação, proliferação e inibição. $O$ processo regenerativo exige uma interação estreita entre os sinais da matriz extracelular e o meio intracelular. A resposta das células remanescentes, como a transcrição de genes e a codificação de novas proteínas, deve ser precocemente estabelecido, pois isto resulta no início da proliferação celular, que segue uma resposta rápida, mas controlada através do envio de sinais para iniciação e parada do processo regenerativo (TARLÁ et al., 2006b) (Figura 4).

Uma série de eventos regulados por citocinas e fatores de crescimento são necessários na iniciação; estes reguladores do processo regenerativo necessitam de uma transformação na matriz extracelular; entre estes fatores extracelulares, proteinases, serinas e metaloproteinases (MMPs), existe uma cascata proteolítica complexa que requer um mecanismo específico de ativação ou como enzimas latentes, inibida por proteases inibitórias específicas (TIMPs) e microglobulinas (RAO, 2003; TARLÁ et al., 2006a). O processo proteolítico é um mecanismo para modificar sinais pré-existentes sem a necessidade de uma nova síntese. A clivagem proteolítica que ocorre na interface pericelular pode funcionar como um ativador ou inibidor do processo de sinalização celular, e pode modificar ou atuar diretamente nas proteínas de ligação (TARLÁ et al., 2006a) (Figura 4).

$\mathrm{Na}$ iniciação ocorre uma resposta mitogênica que se divide em duas fases; primeiro as citocinas estimulam a transição G0-G1, em seguida, a progressão até a fase S. O fator de transcrição NF-KB (fator nuclear que potencializa canais Kappa das células B ativadas) controla a expressão dos genes codificadores de citocinas, regulam o ciclo celular e é um antagonista da apoptose no processo regenerativo hepático (KOUNTOUAS; BOURA; 
LYGIDAKIS, 2001). A STAT (proteína transdutora de sinal e ativadora da transcrição) é importante na inibição da apoptose dos hepatócitos pela inibição da caspase 3 e ativação da 8 (HAGA et al., 2003) (Figura 4).

Em uma segunda fase, o fator de crescimento do hepatócito (HGF) e seu receptor MET são considerados a estimulação central para a progressão G1-S nos hepatócitos remanescentes (MICHALOPOULOS; DEFRANCES, 1997). O HGF é secretado na forma de uma pro-enzima, a pro-HGF, esta enzima deve ser metabolizada na MEC pelas MMPs, juntamente com o uPA (ativador de plasminogênio tipo uroquinase) (LEE, 2000).

Na proliferação a expressão de TGF- $\alpha$ (fator de crescimento de transformação alfa) é iniciada nos hepatócitos em torno de 2-3 horas após a hepatectomia parcial, o que estimula a proliferação dos hepatócitos e das células endoteliais (10). A substância de estimulação hepática (HSS), um fator de crescimento peptídico, específico do fígado, está relacionada à proteção e à proliferação de hepatócitos através da reparação de síntese de DNA e de autofosforilação dos resíduos de tiroxina do receptor EGFR (receptor do fator de crescimento epidérmico) (AN et al., 1999) (Figura 4).

MMP-9 e plasmina são capazes de aumentar os níveis livres de VEFG, promovendo angiogênese induzida durante o processo de regeneração (LECOUTER et al., 2003).

$\mathrm{Na}$ fase de inibição os sinais para o término do crescimento ou parada de sinais são responsáveis pela diminuição da síntese de DNA; o mais conhecido deles é o TGF- $\beta$, (fator de crescimento de transformação beta) secretado pelos hepatócitos e plaquetas (NIHIKAWA; WANG; CARR, 1998) (Figura 4). 


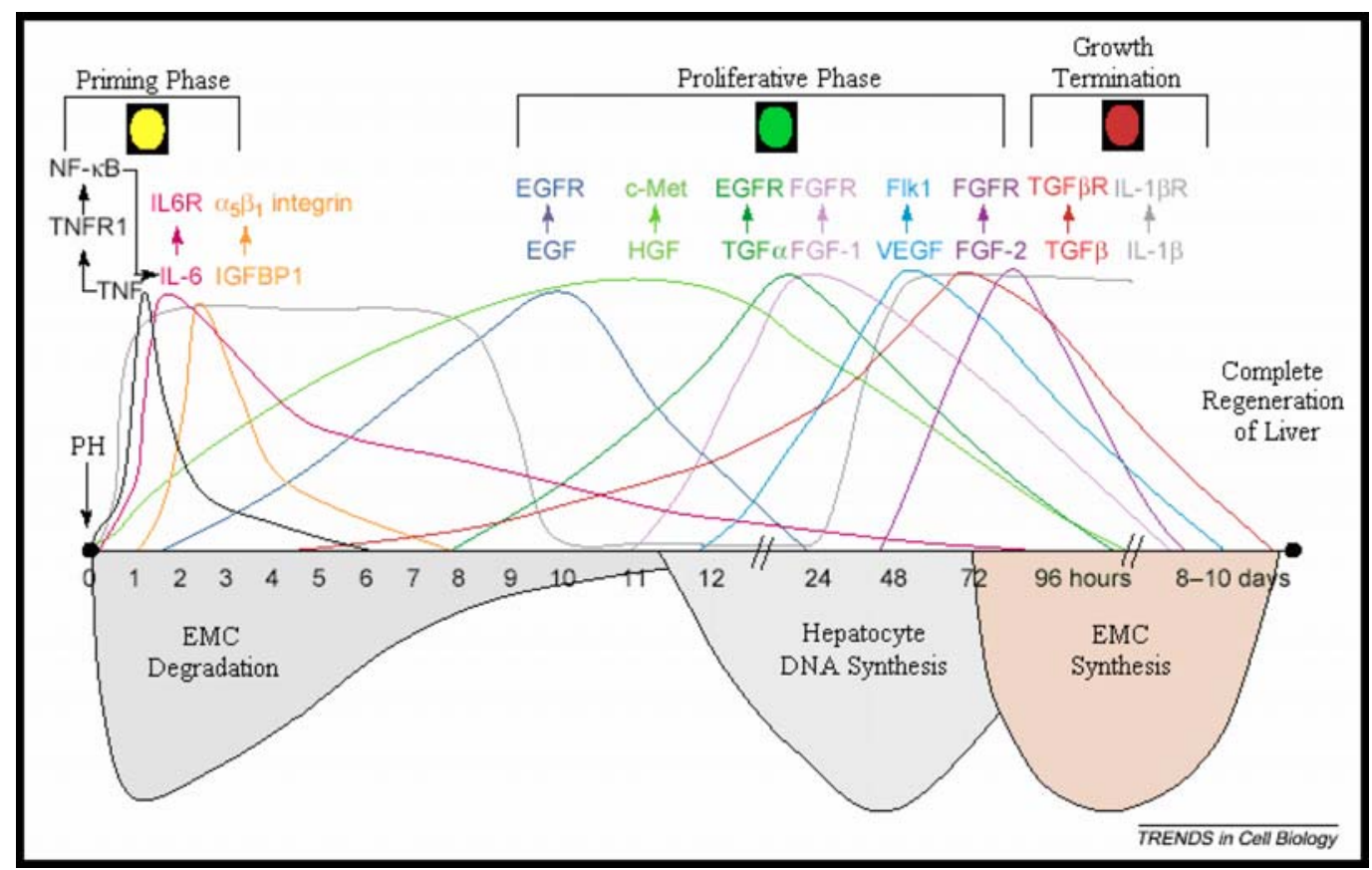

Fonte: (MOHAMMED; KHOKHA, 2005)

Figura 4 - Esquema para o início e fim da regeneração hepática

Têm sido demonstrado em estudos com células tronco hematopoéticas que a quimiocina SDF-1 (fator derivado do estroma da medula óssea), um potente quimiotático secretado pelos hepatócitos danificados e seus receptores (CXCR4, receptor de quimiocina CXC tipo 4), participa do processo de mobilização e migração de células tronco da medula óssea para o tecido hepático danificado (DALAKAS et al., 2005).

Outro dado interessante acerca dos eventos regenerativos, de acordo com estudos recentes, é que a extensão e a regulação da regeneração hepática, após hepatectomia parcial, sofrem influência do ritmo circadiano. Nesses estudos, o pico de replicação do DNA ocorreu 36 horas após a cirurgia, indiferentemente do horário em que o procedimento foi realizado, porém, a entrada em mitose das células cujo DNA foi replicado aconteceu sempre no mesmo período do dia (FAUSTO; CAMPBELL; RIEHLE, 2006). 


\subsection{PROCESSOS PATOLÓGICOS HEPÁTICOS}

Neste capítulo serão abordados os processos patológicos que são de interesse no presente trabalho.

\subsubsection{Fibrose}

$\mathrm{Na}$ lesão leve e transitória do fígado ocorre rapidamente substituição das células mortas pelo processo de regeneração, mas se a lesão é grave e prolongada, ocorre uma resposta cicatrizante da qual resulta a fibrose (ALBANIS; FRIEDMAN, 2006). Caracterizada por síntese excessiva e deposição de matriz extracelular (MEC), a fibrose consiste principalmente de colágeno, proteoglicanos e glicoproteínas não colagenosas (SCHUPPAN et al., 2001).

É, portanto, a resposta cicatricial do fígado à maioria das doenças hepáticas inflamatórias crônicas, como as hepatites B e C, doenças autoimunes ou metabólicas, por exemplo, a hemocromatose. O resultado final é o acúmulo de matriz extracelular (MEC) e a substituição do colágeno tipo IV, de baixa densidade, pelo colágeno tipo I de alta densidade, dentro do espaço de Disse (ALBANIS; FRIEDMAN, 2006). No fígado fibrótico, embora a fibrose seja o evento principal, ela acontece associada a mecanismos de distorção arquitetural, regeneração celular e redistribuição vascular, alterando gravemente a função hepática (BEDOSSA; PARADIS, 2003; BRUCK et al., 2007).

A MEC compreende menos que 3\% da área hepática no fígado sadio; a MEC está restrita aos tratos portais, veias centrais e paredes dos sinusóides. A coesão mecânica e a resistência do fígado são as principais funções da MEC, mas ela também é importante em várias funções biológicas como proliferação, migração e diferenciação celular e expressão gênica (BEDOSSA; PARADIS, 2003). As moléculas constituintes da MEC são importantes nas interações entre as células e a matriz e das células entre si. A MEC retém grande 
quantidade de água compondo o líquido intersticial, de fundamental importância na integração de todo o organismo (ANDRADE, 2005).

Grande parte das proteínas da MEC é composta por colágeno; tipos I, III, IV e V são os mais abundantes. O colágeno tipo IV está associado com a laminina, formando a membrana basal descontínua ao longo dos sinusóides, uma estrutura de baixa densidade, característica essencial para permitir a difusão entre o sangue e as células hepáticas e manter a função diferenciada entre células vizinhas. Os outros tipos de colágeno estão confinados principalmente no espaço porta e na veia central (BEDOSSA; PARADIS, 2003).

A excessiva deposição de MEC no espaço de Disse demanda no acúmulo de colágeno tipo I e III e na constituição de uma estrutura de fibras colágenas que substitui o material constituinte da membrana basal. Esse processo, associado à perda das fenestrações das células endoteliais, é chamado “capilarização dos sinusóides" e resulta em prejuízo nas trocas entre o sangue e as células hepáticas (BEDOSSA; PARADIS, 2003; BRUCK et al., 2007).

Os componentes principais da fibrose hepática são as células estreladas (BATALLER; BRENNER, 2005), embora possa haver também a ativação de fibroblastos portais e perivasculares (SCHUPPAN et al., 2003). Após injúria, as células estreladas tornam-se ativadas. O processo de ativação é caracterizado pela perda das gotículas lipídicas ricas em vitamina A, produção de MEC e expressão de $\alpha$-actina de músculo liso ( $\alpha$-SMA) (LE COUTEUR et al., 2008). As células estreladas diferenciam-se em miofibroblastos capazes de proliferação e fibrogênese, tornam-se contráteis e, devido a sua localização, podem comprimir os sinusóides aumentando a resistência portal (ALBANIS; FRIEDMAN, 2006) (Figura 5). 


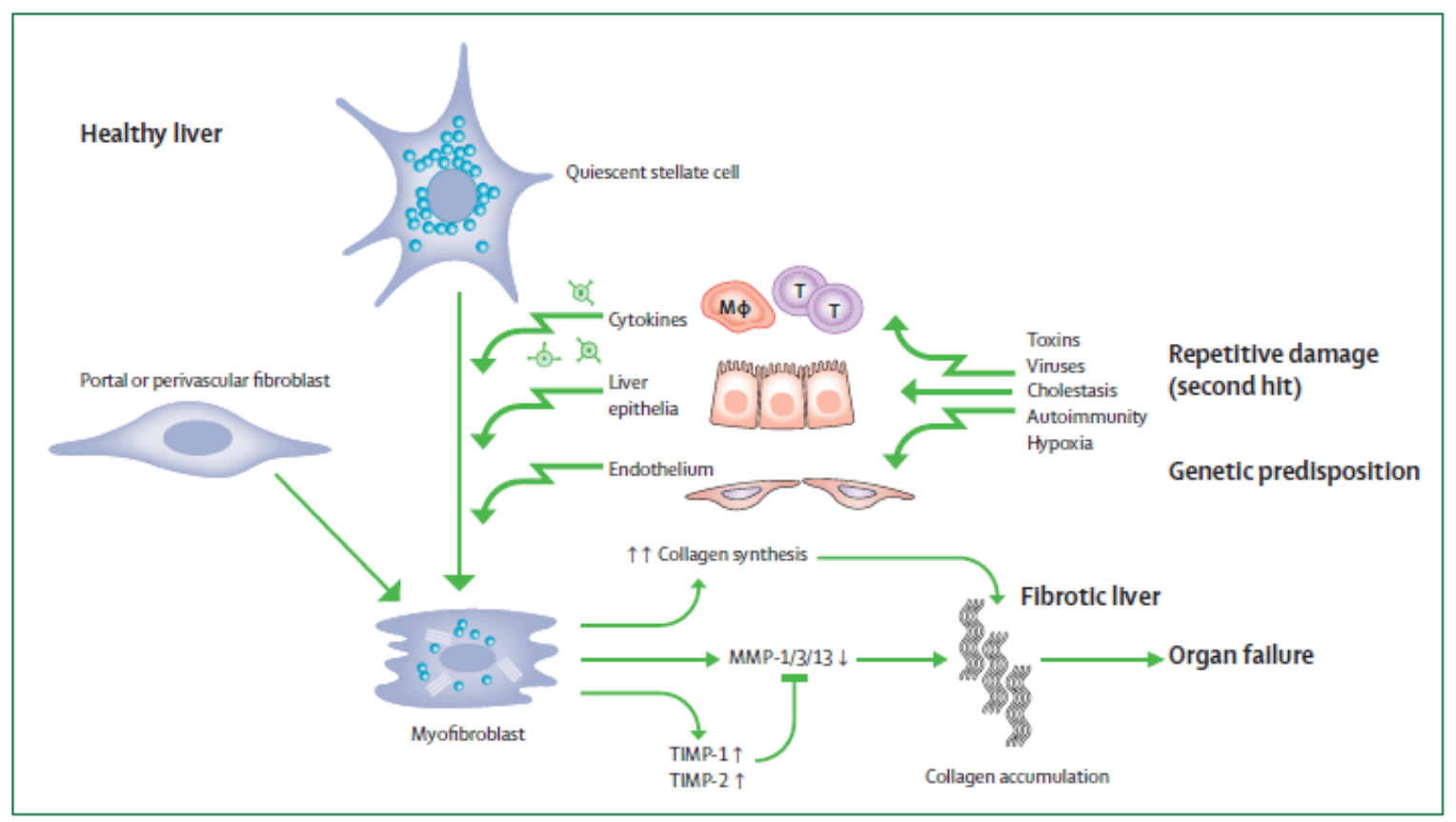

Fonte: (SCHUPPAN; AFDHAL, 2008)

Figura 5 - Esquema da iniciação e manutenção de fibrogênese

A produção de MEC se dá na mesma proporção da sua degradação no fígado normal. Todavia, na fibrose ocorre um desequilíbrio desse balanço. As metaloproteinases de matriz (MMPs) são as responsáveis pela quebra da MEC. A regulação dessas proteinases é complexa, mas essencialmente, elas são ativadas através da clivagem proteolítica e são inibidas pela ligação a inibidores específicos, denominados inibidores teciduais de metaloproteinase (TIMPs). A diminuição da atividade das MMPs por redução da sua expressão gênica ou pelo aumento da atividade dos TIMPs favorece o acúmulo de MEC. As células estreladas são as maiores fontes de TIMPs do tecido hepático (SCHUPPAN et al., 2003). Um capítulo com maiores detalhes referente às MMPs e TIMPs encontra-se no item 3.5 .

Considerada um processo patológico progressivo, a fibrose envolve múltiplos eventos celulares e moleculares, leva à produção e deposição excessiva de MEC. Quando esse processo é combinado com regeneração e reparo ineficazes, ocorre uma distorção da arquitetura hepática normal resultando em cirrose (ZHENG et al., 2005). 


\subsubsection{Cirrose}

A cirrose hepática é um processo de caráter crônico e irreversível, caracterizado por modificações das unidades histológicas básicas do fígado; nódulos de regeneração e desarranjo dos hepatócitos estão presentes, associado ao aumento difuso de tecido conjuntivo, o que resulta na desorganização da arquitetura lobular e vascular (CONN; ATTERBURY, 1987; ROBBINS; COTRAN; KUMAR, 1996; DESMET; ROSKAMS, 2004).

É considerado um processo irreversível, mas há estudos sugerindo que a regressão e até mesmo a reversão da cirrose são possíveis (GARCIA-BAÑUELOS et al., 2002; KUMAR; SARIN, 2007; SATO et al., 2008; SOBREVALS et al., 2010).

Os fatores de risco para a cirrose são, quantidade e duração do consumo de álcool; transmissão da hepatite B (ZHANG et al., 2008) e C (GARCÍA et al., 2002), lugar de origem de áreas endêmicas, exposição ao risco de história sexual, uso de droga intravenosa e intranasal, piercing corporal, tatuagem, contaminação com fluídos corporais ou sangue, assim como história de transfusão, ou história pessoal ou familiar de doença hepática ou autoimune (FRIEDMAN; SCHIANO, 2004).

$\mathrm{Na}$ clínica veterinária, as injúrias hepáticas crônicas são comuns em cães e podem culminar em cirrose (WATSON, 2004; BROWN et al., 2010). As causas dessa patologia abrangem inflamações do trato gastrintestinal, uso prolongado de corticóides, anticonvulsivos e imunoterapia para Corynebacterium parvum e também infecções virais (adenovírus canino tipo I). O armazenamento de cobre é outra doença hepática crônica observada com relativa frequência, especialmente em cães "Bedlington terrier", associada a fatores genéticos (FUENTEALBA et al., 1997). Essa doença hepática é diferente da doença de Wilson descrita em humanos, na qual o defeito na produção de um carreador de cobre implica na sua deposição em vários órgãos, inclusive o fígado. Nessa raça de cão, outros órgãos não são afetados e a falha ocorre na excreção biliar do metal (WATSON, 2004).

Independentemente do fator etiológico e da espécie, o desenvolvimento da doença compreende uma injúria persistente seguida de regeneração, perda de função hepática, desarranjo arquitetural e fibrose (DÍAZ-GIL et al., 1999). 
Pela histologia, a cirrose é determinada por fibrose intensa constituindo septos vascularizados que ligam os tratos portais uns com os outros e/ou com as veias centrolobulares. Há formação de nódulos de hepatócitos regenerativos circundados por esses septos, e desprovidos de veia central, conferindo aspecto rígido ao órgão (ZAIDAN DAGLI; HERNANDEZ-BLAZQUEZ, 2007; SCHUPPAN; AFDHAL, 2008). A hiperplasia de ductos biliares também é freqüentemente observada (AL-BADER et al., 2000; JEONG et al., 2001). Há um processo generalizado de regeneração do parênquima hepático acompanhado por alterações vasculares, como conexões artério-venosas, desvios porto-sistêmicos (circulação colateral) e capilarização sinusoidal (KUMAR; SARIN, 2007).

A formação de tecido conjuntivo vascularizado dá origem à fibrose septal e perisinusoidal que interrompe a continuidade parenquimal (POPPER, 1977; RAPPAPORT et al., 1983). Os vasos presentes nos septos conjuntivos fibróticos podem derivar dos sinusóides que permanecem nas áreas de colapso pós necrótico da estrutura de tecido conjuntivo, ou derivar da angiogênese associada à fibrogênese (ROSMORDUC et al., 1999; CORPECHOT et al., 2002).

Geralmente a cirrose é assintomática, seu desenvolvimento não é sentido ou suspeitado até que suas complicações se apresentem. As principais conseqüências clínicas dessa doença são o prejuízo da função celular, a hipertensão portal e o desenvolvimento de hepatocarcinoma. Outras complicações como varizes esofágicas, ascite, peritonite bacteriana e encefalopatia são comuns da cirrose (SCHUPPAN; AFDHAL, 2008), a qual pode levar também ao desenvolvimento de cardiomiopatia cirrótica (LEE; GLENN; LEE, 2007; MILANI et al., 2007) e síndrome hepatopulmonar (GAINES; FALLON, 2004; PALMA; FALLON, 2006; FREIRE et al., 2007).

Aproximadamente $50 \%$ dos pacientes com cirrose desenvolvem varizes, mais comumente $2-5 \mathrm{~cm}$ distal ao esôfago, estas se desenvolvem devido à hipertensão portal e ao aumento da resistência ao fluxo sanguíneo portal, secundário à fibrose, com consequente compressão dos sinusóides hepáticos (CALES et al., 1990).

O tratamento defintivo para a cirrose nos estágios finais da doença é o transplante hepático (SCHUPPAN; AFDHAL, 2008). Dados recentes (ROBERTS et al., 2004) indicam que o índice de sobrevivência em anos após o transplante é de $83 \%, 70 \%$, e $61 \%$ em 1, 5, e 8 anos, respectivamente. 


\subsection{MATRIZ EXTRACELULAR E CIRROSE HEPÁTICA}

No processo de cirrose hepática ocorre aumento do conteúdo de MEC (é até seis vezes maior do que a quantidade existente no fígado normal). A proporção total de colágeno pode passar de $2 \%$ para até $30 \%$ do total de proteínas do fígado (PINES et al., 1997; SPIRA et al., 2002).

As CEHs (células estreladas hepáticas) ativadas por uma variedade de estímulos fibrogênicos aumentam a deposição da MEC, aumentando a liberação de colágeno fibrilar tipo I (FRIEDMAN, 1993; GARCÍA et al., 2002; SCHAEFER et al., 2003) e tipo III (SCHUPPAN et al., 1999; FRIEDMAN, 2000; BRENNER et al., 2000). As CEHs quiescentes sintetizam baixos níveis de proteínas de matriz, entretanto, quando ocorre algum evento em que ocorre injúria hepática as CEHs proliferam e transformam-se em miofibroblastos ativos, estas células ativadas expressam $\alpha$-actina de músculo liso ( $\alpha$-SMA) e liberam pro-colágeno I (FRIEDMAN, 1993) (Figura 6).

Os miofibroblastos têm várias propriedades características não somente no fígado, mas também em todos os tecidos que apresentam uma resposta à cicatrização. Sua principal característica é expressar $\alpha$-SMA, um filamento contrátil, e no fígado é marcado como uma célula fibrogênica (GAWRIEH et al., 2005). Os miofibroblastos também sintetizam um conjunto de componentes da MEC, MMPs e seus inibidores, e liberam uma série de citocinas e quimiocinas. 


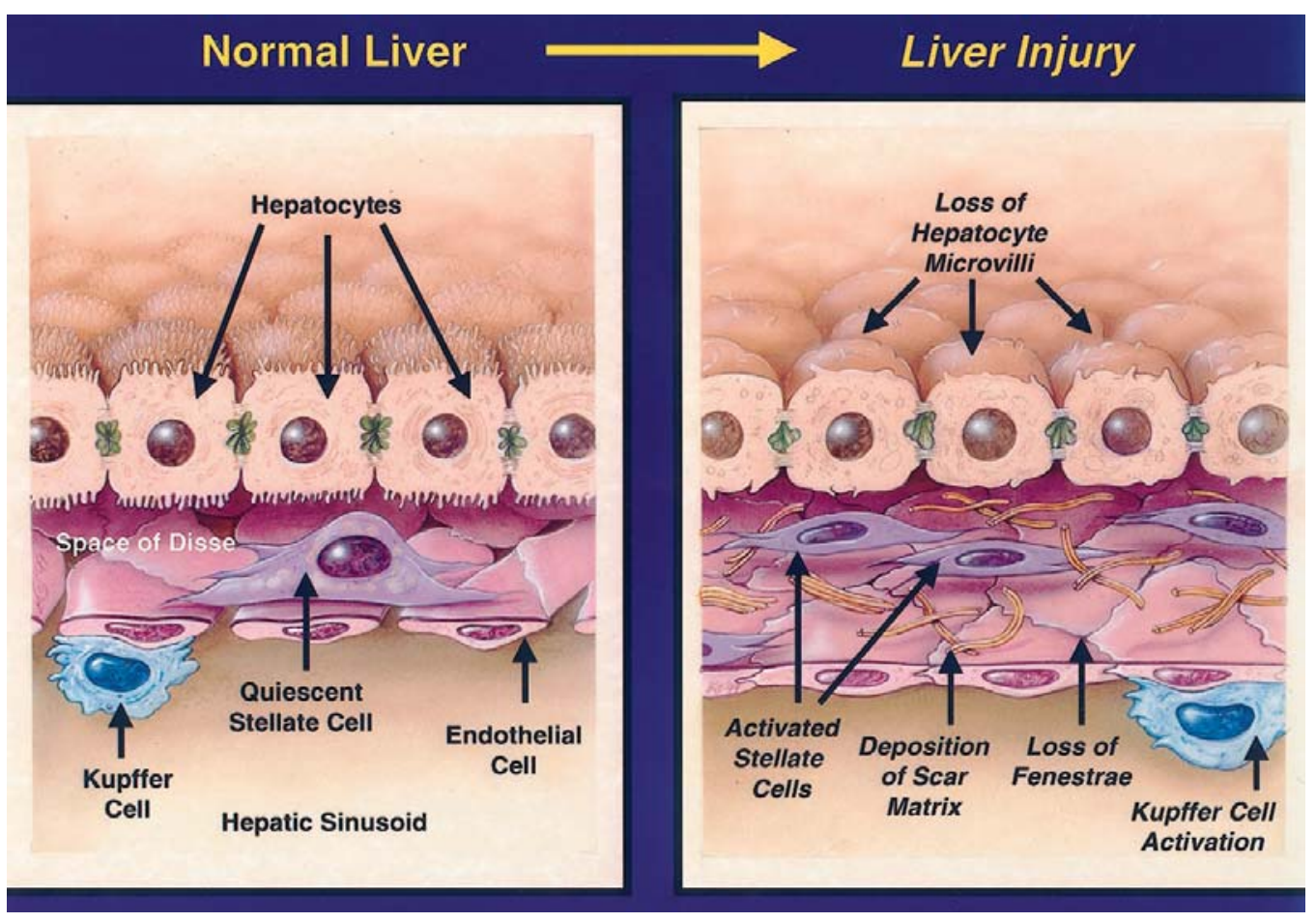

Fonte: (FRIEDMAN, 2000)

Figura 6 - Esquerda: fígado normal, direita: injúria hepática. A lesão hepática leva a ativação das células de Kupffer (residentes no espaço sinusoidal), que por sua vez contribuem na ativação das $\mathrm{CEHs}$

\subsubsection{Mecanismos de ativação das células estreladas hepáticas}

A ativação consiste em duas fases principais; iniciação (também chamado de "estágio pré-inflamatório") e perpetuação (FRIEDMAN, 2004), seguida por uma fase de resolução quando a lesão hepática é solucionada (Figura 7).

Iniciação, a primeira mudança observada durante a ativação das CEHs resulta da estimulação parácrina por todos os tipos de células vizinhas, incluindo o endotélio sinusoidal, hepatócitos e plaquetas. Os hepatócitos são potentes fibrogênicos reativos ao oxigênio; este caráter conferido aos hepatócitos é gerado por injúria na membrana e pela peroxidação lipídica (NOVO et al., 2006). Fragmentos apoptóticos liberados dos hepatócitos são fibrogênicos em cultura de células estreladas (CANBAY et al., 2003b), e ativam as células de Kupffer (CANBAY et al., 2003a) (Figura 7). 
A infiltração e ativação das células de Kupffer também contribuem para a ativação das CEHs. As células de Kupffer estimulam a síntese de matriz, proliferação celular e liberação de retinóides pelas CEHs por meio das ações de citocinas (especialmente do TGF- $\beta 1$ ) e por espécies oxigênio reativas (BILZER; ROGGEL; GERBES, 2006). As células endoteliais também são promissoras por participar na conversão de TGF- $\beta$ latente para a forma ativa e formas pro-fibrogênicas; estes produzem uma isoforma celular de fibronectina, que provoca a ativação precoce das CEHs (JARNAGIN et al., 1994).

Perpetuação, a ativação das CEHs envolve pelo menos seis alterações no comportamento celular; a proliferação, quimiotaxia, fibrogênese, contratilidade, degradação da matriz, e perda de retinóide. O efeito dessas mudanças é aumentar o acúmulo de matriz extracelular, enquanto acelera a substituição da matriz normal por um típico tecido "cicatricial" (FRIEDMAN, 2008b) (Figura 7).

Proliferação, o PDGF (fator de crescimento derivado das plaquetas) é o mais potente mitógeno das CEHs identificados até o momento (PINZANI, 2002; BORKHAMKAMPHORST et al., 2007). A indução precoce de receptores PDGF na ativação das CEHs aumenta a ativação de resposta a este potente mitógeno (WONG et al., 1994). Outros componentes com atividade mitogênica nas CEHs e um papel potencial na fibrogênese incluem o VEGF (fator de crescimento vascular endotelial) (YOSHIJI et al., 2003), trombina e seus receptores (MARRA et al., 1995, 1998), EGF (fator de crescimento epidérmico), TGF$\alpha$, fator de crescimento de queratinócitos (STEILING et al., 2004) e bFGF (fator de crescimento de fibroblasto básico) (YU et al., 2003) (Figura 7).

Quimiotaxia, um número de quimio atrativos foi identificado, dos quais se destacam PDGF (fator de crescimento derivado de plaquetas) (IKEDA et al, 1999; KINNMAN et al., 2000), MCP-1 (proteína quimiotática de monócitos-1) (MARRA et al., 1999) e CXCR3 (receptor quimiocina CXCR3) (BONACCHI et al., 2001).

Em contraste, a adenosina (HASHMI et al., 2007) enfraquece a quimiotaxia e pode imobilizar células, uma vez que alcançam o local da lesão. As características mecânicas da quimiotaxia das CEHs foram recentemente exploradas, revelando que a quimiotaxia PDGFestimulada está associada com a difusão das células, movimento do corpo celular em direção ao estimulante, e retração das saliências "rastejantes" associado com a fosforilação transitória da miosina (MELTON; YEE, 2007) (Figura 7). 
Fibrogênese, as CEHs geram fibrose, não só pelo número celular aumentado, mas também pela produção aumentada de matriz por célula. O componente melhor estudado com a injúria hepática é o colágeno tipo I, cuja expressão é regulada tanto transcricionalmente, quanto pós transcricionalmente nas $\mathrm{CEHs}$ por um número crescente de vias e estímulos (INAGAKI et al., 2003; STEFANOVIC et al., 2004; TSUKADA; PARSONS; RIPPE, 2006) (Figura 7).

O estímulo mais potente para a produção de colágeno I e outros componentes da matriz pelas CEHs vem do TGF $\beta$-1, derivado de fontes parácrina e autócrina (BREITKOPF et al., 2006; INAGAKI; OKAZAKI, 2007). O TGFß-1 também estimula a produção de outros componentes da MEC, incluindo fibronectina e proteoglicanas (GEORGE et al., 2000). O fator de crescimento do tecido conjuntivo (CTGF/CCN2) também é um sinalizador fibrogênico potente para as CEHs (RACHFAL; BRIGSTOCK, 2003; GAO; BRIGSTOCK, 2004).

Contractilidade é um dos principais determinantes do aumento precoce e tardio na resistência portal durante a fibrose hepática. As bandas de colágeno típicas do estágio final da cirrose contêm um grande número de CEHs (ROCKEY, 2001a, b, 2003). Estas bandas impedem o fluxo sanguíneo portal por contrair sinusóides individuais e também o fígado cirrótico. A endotelina-1 e óxido nítrico são os maiores contra reguladores controlando a contratilidade das CEHs (REYNAERT et al., 2002; ROCKEY, 2003). Como a expressão da proteína do citoesqueleto $\alpha$-SMA e as CEHs ativadas estão aumentadas (RAMADORI et al., 1990; ROCKEY et al., 1992); estas características conferem potencial contrátil para tais células (Figura 7).

Perdas de retinóides, a ativação das CEHs é acompanhada pela perda do retinóide perinuclear característico (vitamina A) (FRIEDMAN; WEI; BLANER, 1993).

Resolução, para que ocorra a resolução do processo de injúria hepática, é necessário que haja redução das CEHs ativadas; reversão destas células para um fenótipo mais quiescente ou ainda a apoptose. Uma grande quantidade de evidências sustentam a importância da apoptose das CEHs durante a regressão da fibrose hepática (ISSA et al., 2001; IREDALE, 2001) (Figura 7). 


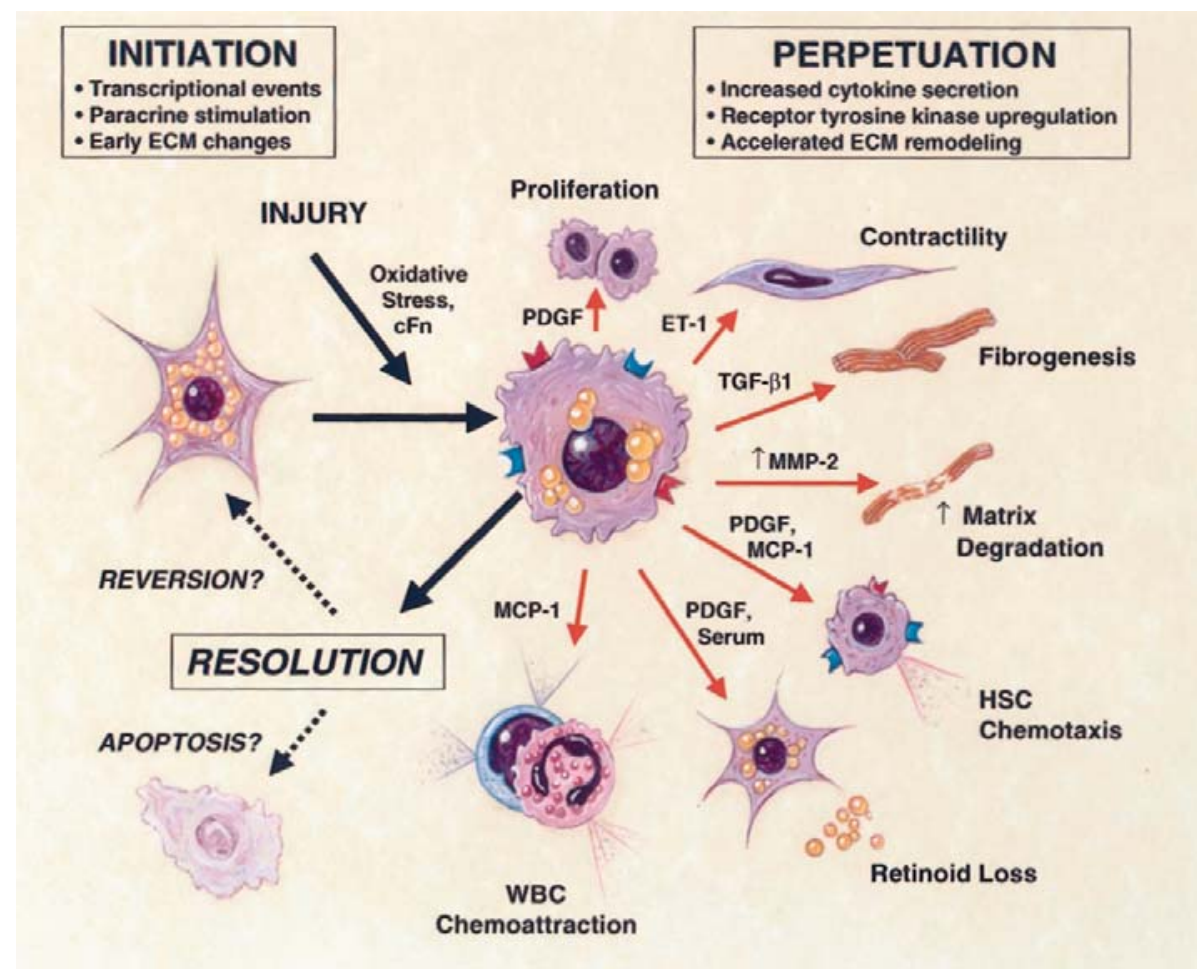

Fonte: (FRIEDMAN, 2000)

Figura 7 - Características fenotípicas da ativação das células estreladas hepáticas durante a lesão e resolução no fígado

As proteínas da MEC produzidas pelas CEHs quiescentes são tipicamente depositadas nas membranas basais (laminina, colágeno tipo IV e entactina) enquanto as CEHs ativadas sintetizam mais proteínas (colágeno tipo I) localizadas no interstício (RAMADORI et al., 1990; RAMADORI, 1991; SAILE et al., 1999; HAUTEKEETE; GEERTS, 1997). As células endoteliais sinusoidais também são capazes de sintetizar proteínas da MEC, como colágeno tipo I, II e IV, fibronectina, tenascina, undulina, laminina, entactina, trombospondina e fator de von Willebrand in vivo e in vitro (IRVING et al., 1984; RIEDER et al., 1987; MAHER; MCGUIRE, 1990; GEERTS et al., 1993; SCHWOEGLER et al., 1994; HERBST et al., 1997; NEUBAUER et al., 1999). 


\subsection{GENES MODULADORES DA MATRIZ EXTRACELULAR}

As metaloproteinases de matriz (MMPs) são fatores chaves na regulação das interações célula/célula e célula/matriz extracelular. Estão envolvidas na modificação da estrutura da matriz, na disponibilidade de fatores de crescimento e da função dos sistemas de sinalização de superfície celular, com consequente efeito na diferenciação celular, proliferação e apoptose; desempenham também um papel central na morfogênese, cicatrização, reparação e remodelação tecidual em resposta à injúria (MURPHY; NAGASE, 2008).

Vários tipos de proteinases têm sido implicados na degradação da MEC, mas um grupo principal de enzimas envolvidas nesta degradação são as MMPs, conhecidas também como matrixinas. Muitos estudos recentes têm mostrado que as MMPs têm outras funções, como na regulação do ambiente celular, modulação de muitas moléculas bioativas na superfície da célula e podem agir em conjunto para influenciar o comportamento celular (EGEBLAD; WERB, 2002).

As matrixinas são MMPs com multidomínio de zinco, apresentam sequências homólogas com o domínio catalítico da colagenase fibroblástica (colagenase 1) ou MMP-1, critérios para a adesão da família. O domínio catalítico contém canais $\mathrm{Zn}^{2+}$ modificados (HEXXHXXGXXH) e uma metionina conservada, formando uma "rotação Met" que suporta a estrutura de fenda em torno do sítio ativo catalítico $\mathrm{Zn}^{2+}$. Assim, eles são membros típicos da metzincina (BODE; GOMIS-RÜTH; STÖCKLER, 1993), mas o que distingue as MMPs de outras metzincina são as estruturas primárias dos domínios catalíticos. As matrixinas são sintetizadas como pré e pro-enzimas, e o sinal peptídico é removido durante a translação para gerar pro MMPs. Os pro-peptídeos têm o modificado "desvio cisteína" PRCGXPD em que resíduo cisteína coordena com o Zn2+ no domínio catalítico, mantendo as proMMPs inativas (VAN WART; BIRKEDAL-HANSEN, 1990) (Figura 8). 


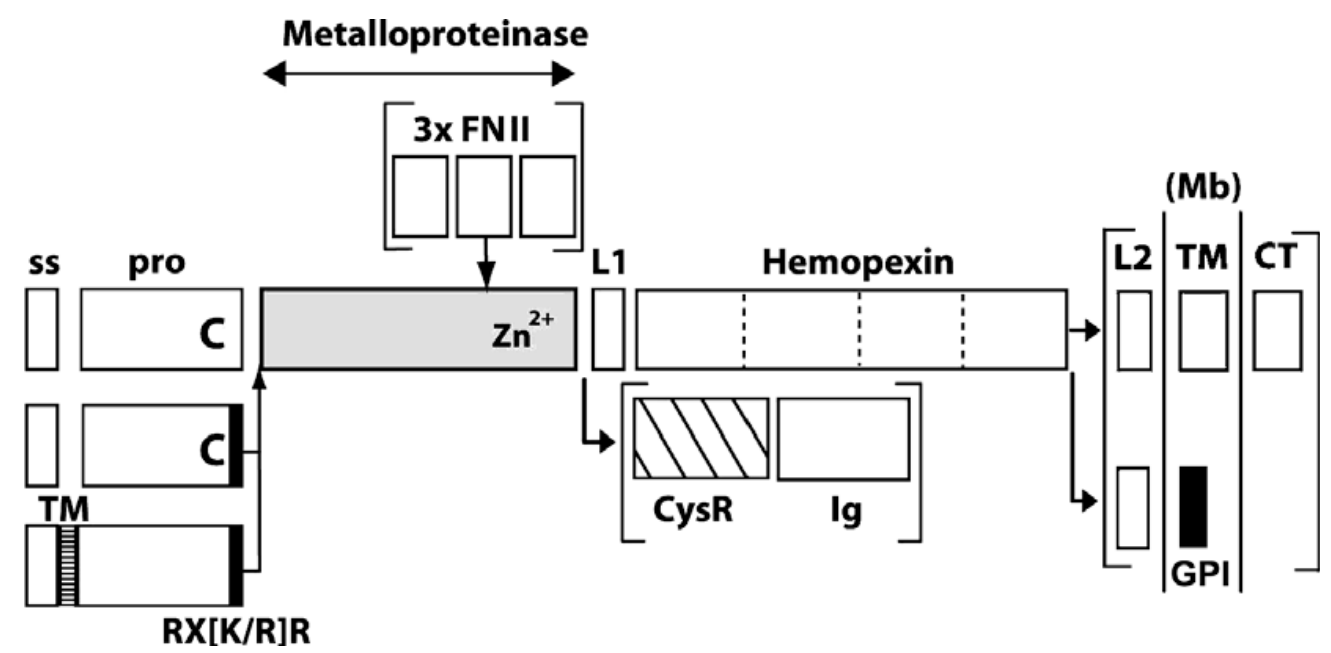

Fonte: (MURPHY; NAGASE, 2008)

Figura 8 - Estrutura de domínio da família das matrixinas. ss, sequência de sinal; pro, prodomínio, FNII, fibronectina tipo II modificada; L1, ligação 1; L2, ligação 2; Mb, membrana plasmática; TM, domínio transmembrana; CT, cauda citoplasmática; CysR, cisteína rica; Ig, domínio da imunoglobulina; GPI, fixação glicosilfosfatidilinositol; C, cisteína

Os principais genes envolvidos na modulação da matriz extracelular do fígado são as colagenases; colagenase 1 (MMP-1), colagenase 2 (MMP-8) e colagenase 3 (MMP-13); as gelatinases; gelatinase A (MMP-2) e gelatinase B (MMP-9); estromelisinas; matrilisinas; MMPs de canais de membrana (MT-MMPs); Fator de Crescimento de Transformação- $\beta 1$ (TGF $\beta 1$ ); Ativador de Plasminogênio tipo Uroquinase (uPA ou PLAU) e inibidores teciduais das metaloproteinases (TIMPs) que se subdividem em inibidores endógenos das MMPs e em mecanismos de inibição dos TIMPs e variantes dos TIMPs.

3.5.1 Colagenase 1 (MMP-1), colagenase 2 (MMP-8) e colagenase 3 (MMP-13)

Consistem de pro-peptídeo, domínios catalíticos e de hemopexina; desempenham um importante papel na clivagem fibrilar de colágenos tipos I, II e III, as colagenases também têm atividade contra outras moléculas da MEC e proteínas solúveis. Os domínios catalíticos das colagenases clivam substratos não colagenosos, porém, são incapazes de clivar colágenos 
fibrilares nativos na ausência de seus domínios de hemopexina. A cooperação entre os dois domínios é considerada importante para a expressão da sua atividade colagenolítica (CHUNG et al., 2004).

\subsubsection{Gelatinase A (MMP-2) e gelatinase B (MMP-9)}

Ambas as enzimas têm três repetições de uma fibronectina do tipo II modificada inserida no domínio catalítico; elas compartilham atividades proteolíticas semelhantes e degradam colágenos desnaturados, gelatinas e um número de moléculas da $\mathrm{MEC}$, incluindo colágenos nativos tipos IV, V e XI, laminina e proteína nuclear agrecan. A MMP-2 digere colágenos nativos tipos I, II e III de forma semelhante às colagenases (AIMES; QUIGLEY, 1995; PATTERSON et al., 2001), mas MMP-9 não. Contudo, a atividade colagenolítica da MMP-2 é muito mais fraca que a MMP-1 ou outras colagenases.

O proMMP-2 é recrutado para a superfície celular e ativado pelos canais MT-MMPs (MMP tipo membrana) de membrana, e podem se acumular pericelularmente e expressar atividade colagenolítica local (MURPHY et al., 1985) (Figura 9). 


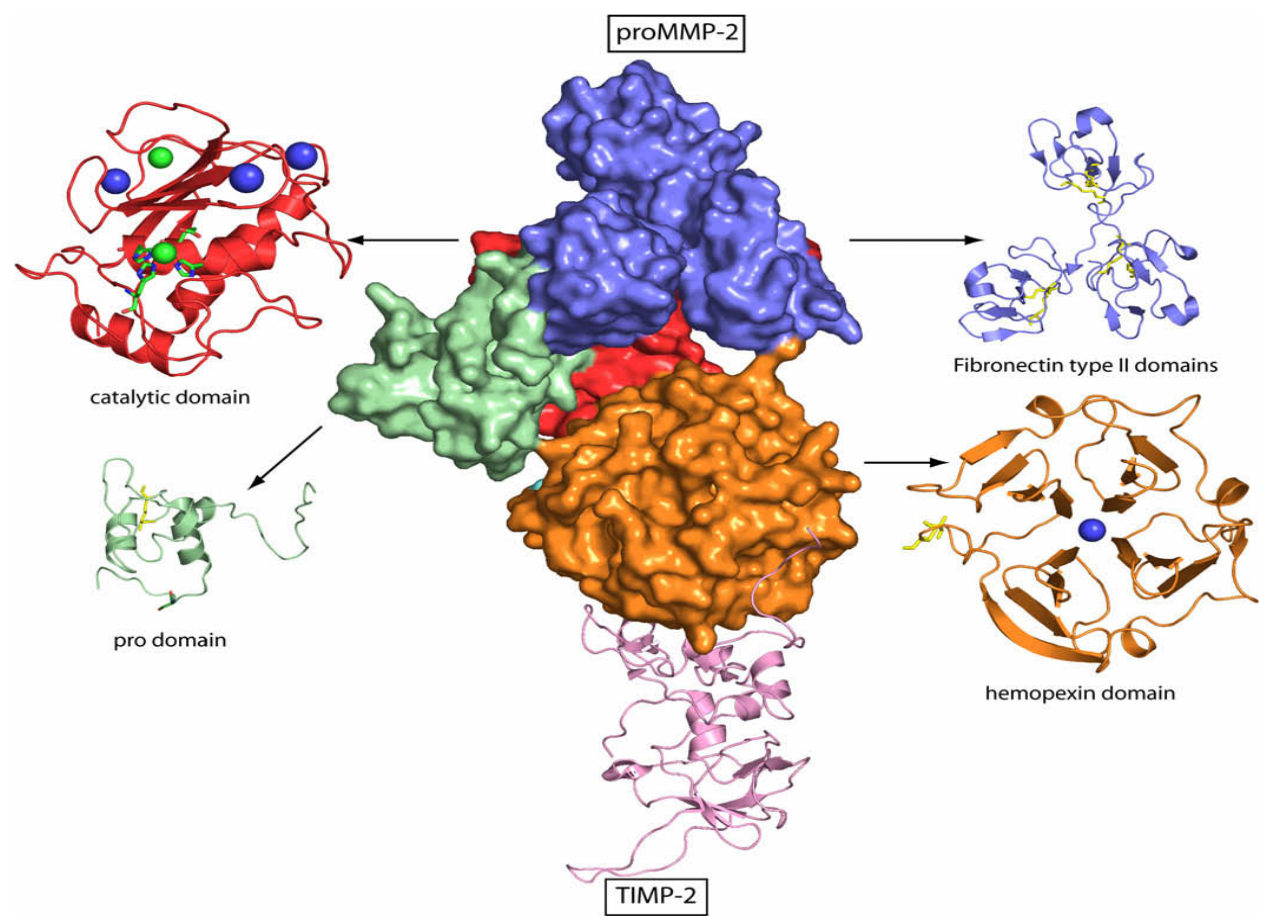

Fonte: (MURPHY; NAGASE, 2008)

Figura 9 - Diagrama tridimensional do complexo proMMP-2 e TIMP-2 de humano. Pro-domínio, em verde; domínio catalítico, em vermelho; domínio da fibronectina tipo II, em azul; domínio da hemopexina, em laranja; TIMP-2, em rosa; íons do zinco, esfera verde; íons de cálcio, esfera azul; pontes dissulfeto, em amarelo

\subsubsection{Estromelisinas}

MMP-3, MMP-10 e MMP-11 são denominadas estromelisinas 1, 2 e 3, respectivamente; tem a mesma organização de domínio que as colagenases, mas elas não clivam colágeno intersticial. MMP-3 e MMP-10 digerem uma série de moléculas da MEC e participam na ativação da proMMP, porém a atividade da MMP-11 é muito fraca (MURPHY et al., 1993). Outra diferença é que tanto a MMP-3, como a MMP-10 são secretadas pelas células como proMMPs inativas, mas MMP-11 é ativada intracelularmente pela furina e secretada da célula como uma enzima ativa (PEI; WEISS, 1995). 


\subsubsection{Matrilisinas}

MMP-7 e MMP-26 pertencem a esta categoria; a característica estrutural destas MMPs é a deficiência do domínio hemopexina. MMP-7 é sintetizada pelas células epiteliais e secretada apicalmente; ela degrada componentes da MEC, mas também cliva moléculas da superfície celular como ligantes Fas (proteína de fusão), fator $\alpha$ de necrose pro-tumoral, sindecam 1 e caderina-E (PARKS; WILSON; LÓPEZ-BOADO et al., 2004). MMP-26 é expressa em células normais como as do endométrio e em alguns carcinomas; esta MMP digere várias moléculas da MEC (MARCHENKO et al., 2004).

\subsubsection{MMPs de canais de membrana (MT-MMPs)}

Dois tipos de MT-MMPs são observados; incluem quatro proteínas transmembrana tipo I (MMP-14, -15, -16 e -24) e duas proteínas ancoradas glicosilfosfatidilinositol (MMP-17 e -25). Todas elas têm uma sequência de reconhecimento convertase pro-proteína como furina $\mathrm{RX}[\mathrm{R} / \mathrm{K}] \mathrm{R}$ no terminal-C do pro-peptídeo. São ativadas intracelularmente e ativam enzimas que são susceptíveis de ser expressas na superfície celular. Todas as MT-MMPs, exceto MT4MMP (MMP-17) (ENGLISH et al., 2001) podem ativar proMMP-2. MT1-MMP (MMP-14) pode ativar proMMP-13 na superfície da célula (KNÄUPER et al., 1996b). No entanto, MT1MMP apresenta própria atividade colagenolítica contra colágenos tipos I, II e III (OHUCHI et al., 1997). 


\subsubsection{Fator de Crescimento de Transformação- $\beta 1$ (TGF- $\beta 1)$}

Este fator de crescimento faz parte de uma grande família de citocinas; apresentam secreção pleiotrópica e estão estruturalmente inter-relacionadas. Os membros da família do TGF- $\beta$ têm atividades imunossupressoras potentes, in vitro e in vivo. Estas citocinas disparam seus efeitos biológicos por induzir a formação de um complexo receptor serina transmembrana heteromérica/treonina quinase (DENNLER; GOUMANS; TEN DIJKE, 2002).

O TGF- $\beta$ é um regulador que apresenta várias funções, dentre elas, regula a proliferação e migração de células musculares lisas vasculares e endoteliais; inibe o crescimento e a diferenciação celular; promove apoptose; regula a proliferação, diferenciação e ativação das células imunes; faz a adesão e migração de vários tipos celulares; e favorece a produção de proteínas da MEC. Muitos tipos de células, incluindo células hematopoiéticas imaturas, como as células T e B ativadas, macrófagos, neutrófilos e células dendríticas, produzem TGF- $\beta$ e/ou são sensíveis aos seus efeitos (LETTERIO; ROBERTS, 1998; CERWENKA; SWAIN, 1999; LEBMAN; EDMISTON, 1999; DENNLER; GOUMANS; TEN DIJKE, 2002).

A baixa regulação do TGF- $\beta$ tem sido implicada em várias doenças humanas, incluindo câncer, desordens vasculares, doenças auto-imunes e fibrose (DENNLER; GOUMANS; TEN DIJKE, 2002) (Figura 10).
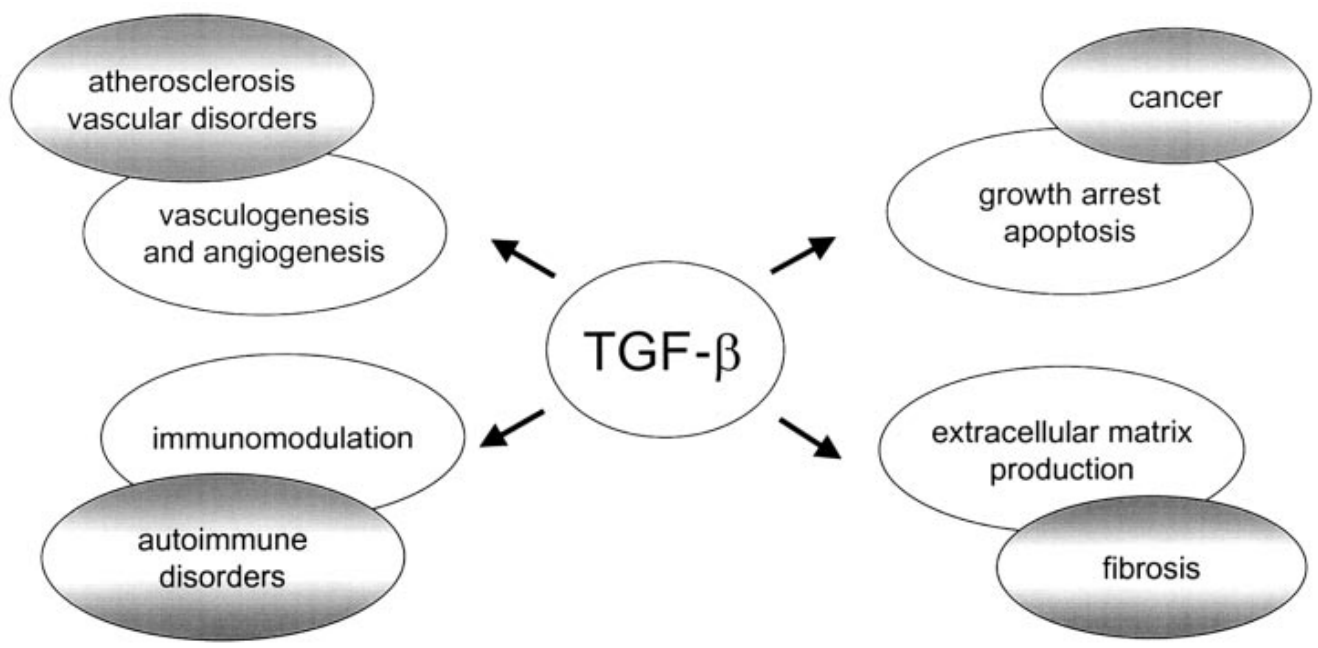

Fonte: (DENNLER; GOUMANS; TEN DIJKE, 2002)

Figura 10 - Alterações observadas com a baixa regulação do TGF- $\beta$ 
O TGF- $\beta$ favorece a produção de proteínas da MEC por ativar as CEHs durante a fibrose hepática (BENTEN et al., 2005). A ativação das CEHs pelo TGF- $\beta 1$ se dá pelo caminho TGF- $\beta 1 /$ Smad (proteína intracelular de transdução de sinal extracelular ligada ao fator de crescimento de transformação beta) (PINZANI; MARRA; CARLONI, 1998; LI, WEI, 2005), que após combinação com seus receptores (T $\beta$ RI e T $\beta$ RII) na membrana celular, o TGF- $\beta 1$ ativado entra em uma via de transdução de sinal.

Inicialmente o TGF $\beta$-1 primeiro combina com os receptores T $\beta$ RII, e em seguida com os receptores T $\beta R I$. A fosforilação do T $\beta R I$ é uma etapa chave no processo da transdução do sinal (CALABRESE et al., 2003; DI et al., 2003; MEURER et al., 2005). Smad2 e Smad3 conduzem a transdução do sinal intracelular do TGF $\beta$-1. Depois de fosforilado, eles combinam com Smad4 para formar multímeros. Após serem transportados dentro dos nucléolos, eles combinam com um co-ativador ou um co-repressor para regular a transcrição de um gene alvo, assim como para realizar o efeito biológico do TGF $\beta-1$ (QIN et al., 2002; XU et al., 2003).

\subsubsection{Ativador de Plasminogênio tipo Uroquinase (uPA ou PLAU)}

É uma protease serina como a tripsina que pode ativar o plasminogênio em plasmina cataliticamente ativa. uPA é uma molécula central na proteólise pericelular e remodelação da MEC, e a principal função biológica do tPA (ativador do plasminogênio tecidual) parece estar associada à fibrinólise (CARRIERO et al., 2009). Enquanto tPA é ativo, uPA é essencialmente inativo (pro-uPA) (PETERSEN et al., 1988).

A clivagem do pro-uPA pela plasmina, calicreína, fator XIIa ou catepsina B (KOBAYASHI et al., 1991) produz o dissulfeto ligado a enzima ativa de duas cadeias. Os dois PAs (ativadores de plasminogênio) têm distintos determinantes alvo em suas regiões não catalíticas, o "domínio do fator de crescimento" do uPA direciona a ligação da enzima (e da pro-uPA) para um receptor na membrana plasmática (VASSALLI; BACCINO; BELIN, 1985; BLASI et al., 1990), enquanto outros domínios estruturais no tPA permitem a sua ligação à fibrina e outros componentes da MEC (GETHING et al., 1988). 
O plasminogênio está presente no plasma e no fluído extracelular. Pode estar associado com a fibrina e outras proteínas através dos sítios de ligação da lisina localizados na sua porção não catalítica (PLOW; MILES, 1990). uPA ativa, por sua vez catalisa a ativação do plasminogênio. A plasmina, em seguida, ativa uma série de proteases, tais como metaloproteinases de matriz (MMPs), desencadeando a remodelação e degradação da MEC (HE et al., 1989). uPA também pode ativar o precursor do fator de crescimento do hepatócito (pro-HGF), que mostra uma extensa homologia com o plasminogênio e as proteínas estimuladoras de macrófagos, indiretamente, controlando a proliferação celular, invasão da MEC e prevenção da apoptose (VAN DER VOORT et al., 2000; COLLEN, 2001).

PAI-1 (inibidor do ativador do plasminogênio 1) e PAI-2 (inibidor do ativador do plasminogênio 2) são dois inibidores endógenos do UPA. PAI-I tem alta afinidade para tPA, assim como por uPA. PAI-I é secretado como uma antiprotease ativa, mas é rapidamente é convertida para uma forma latente inativa, e que pode ser reativada pela exposição a agentes caotrópicos ou fosfolipídios (CUBELLIS; WUN; BLASI, 1990; SEIFFERT et al., 1990; OLSON et al., 1992).

PAI-2 inibe uPA e também, de forma menos eficaz, tPA. A relação constante do uPA e inibição do tPA não são tão favoráveis quanto com o PAI-1, e isso levanta a possibilidade que o PAI-2 pode controlar a atividade de outras enzimas. Neste contexto, é intrigante que PAI-2, além de ser uma proteína secretada, também é abundante no citoplasma de células que o sintetizam (BELIN et al., 1989), enquanto PAs são proteínas exclusivamente secretoras.

Protease nexina I (PN-I) também inibe uPA, plasmina, e trombina; sua reatividade frente a trombina é drasticamente aumentada na presença de heparina. O duplo papel da PN-I como um inibidor da deposição e remoção de fibrina sugere que ela pode ser designada para refrear várias vias enzimáticas, que, se ativas, poderiam afetar o metabolismo do meio extracelular (VASSALLI; SAPPINO; BELIN, 1991). 


\subsubsection{Inibidores teciduais das metaloproteinases (TIMPs)}

Como o próprio nome indica, são os inibidores específicos das MMPs. Os TIMPs e as MMPs tornam-se ativos quando o acúmulo de tecido conectivo reflete uma alteração no balanço entre síntese e degradação da MEC.

\subsubsection{Inibidores endógenos das MMPs}

$\alpha_{2}$-macroglobulina e uma pequena família de inibidores natural especificamente voltado para inibir a atividade das MMPs. Atuam como inibidores das proteinases em geral e podem ser encontradas no sangue e nos fluídos teciduais. A maioria das endopeptidases, independentemente da sua classe, são inibidas pelo aprisionamento da enzima dentro da macroglobulina (BARRETT; STARKEY, 1973). As atividades das MMPs na fase fluida são reguladas principalmente pela $\alpha_{2}$-macroglobulina e proteínas relacionadas.

Estes TIMPs são um grupo de quatro proteínas (21-30 kDa) que, como um grupo inibe efetivamente todas as MMPs in vivo (GOMEZ et al., 1997). O TIMP-1 inibe a enzima ativa MMP-1 (KLEIN; BISCHOFF, 2010); a atividade da MMP-8 é inibida pelos TIMP-1 e -2 (KNÄUPER et al., 1993); MMP-13 é inibida pelos TIMP-1, -2 e -3; (KNÄUPER et al., 1996a), a MMP-13 pode também ser inibida através da ligação a um receptor específico na superfície dos osteoblastos e fibroblastos, resultando em internalização e na sua própria degradação (BARMINA et al., 1999). 


\subsection{FATORES HEPATOTRÓFICOS EM FÍGADOS SADIOS E NO TRATAMENTO DA CIRROSE HEPÁTICA}

A terapia nutricional representa um dos procedimentos de maior importância no manejo das doenças hepáticas, e deve ser considerada como um adjuvante imprescindível como opção terapêutica de que dispõe a clínica (PAROLIN; ZAINA; LOPES, 2002).

\subsubsection{Malnutrição na cirrose hepática}

A desnutrição é uma complicação da doença hepática crônica, que tem importantes implicações prognósticas. Pacientes desnutridos com cirrose têm maiores complicações e, em geral, apresentam um índice aumentado de mortalidade (CAREGARO et al., 1996; ALBERINO et al., 2001).

Uma triagem é necessária em pacientes com doença hepática crônica, este tipo de abordagem pode identificar possíveis pacientes em risco de desenvolver complicações relacionadas a alterações nutricionais (KONDRUP et al., 2003). A terapia nutricional tem o potencial para reduzir o risco de tais complicações (HENKEL; BUCHMAN, 2006).

\subsubsection{Etiologia da malnutrição na cirrose hepática}

Muitos pacientes com doença hepática avançada apresentam alteração do paladar; e uma ingesta oral deficiente, leva a deficiência de vitamina A e/ou de zinco (GARRETTLASTER; RUSSELL; JACQUES, 1984). Frequentemente com a cirrose, os pacientes 
experienciam saciedade precoce devido à compressão mecânica causada pela ascite (TESTA et al., 2000).

Fadiga, fraqueza, e encefalopatia de baixo grau também podem contribuir para a diminuição da ingestão de alimentos; má absorção é outro fator importante, e pode haver uma redução no reservatório de sais biliares, o que leva a má absorção normal de gordura resultando em uma deficiência de vitaminas lipossolúveis (VLAHCEVIC et al., 1971); outro mecanismo é o crescimento excessivo de bactérias resultante da motilidade prejudicada do intestino delgado (GUNNARSDOTTIR et al., 2003).

A presença de hipertensão portal também causa perda protéica gastrointestinal (ROMITI et al., 1990; CONN, 1998), e a administração de medicamentos, tais como a neomicina, utilizado no tratamento da encefalopatia hepática (THOMPSON et al., 1971).

É sugerido que até 30\% dos pacientes com cirrose são hipometabólicos (MÜLLER; BÖKER; SELBERG, 1994; MÜLLER et al., 1999).

\subsubsection{Nutrição enteral na cirrose hepática}

Cabre et al. (1990) constataram que a alimentação enteral melhora os níveis de albumina sérica em pacientes gravemente desnutridos com cirrose, se comparados aos níveis séricos dos pacientes que receberam dieta padrão oral. Hasse et al. (1995) demonstraram o benefício da iniciação precoce da alimentação enteral após transplante. Kearns et al. (1992) mostraram que a intervenção nutricional com alimentação enteral melhorou a doença hepática alcoólica, associada a redução mais rápida dos níveis de bilirrubina e melhora da encefalopatia hepática se comparados ao participantes controles. 


\subsubsection{Nutrição parenteral na cirrose hepática}

Wicks et al. (1994) mostraram que a alimentação parenteral é tão eficaz como a alimentação enteral para a manutenção do estado nutricional após o transplante hepático, e tem a vantagem de diminuir as complicações com a cronicidade da doença hepática. A alimentação parenteral é melhor que a alimentação enteral em pacientes com desvio porto sistêmico, porque esta última pode piorar a hiperamonemia (PLAUTH et al., 2000).

\subsubsection{Fatores hepatotróficos em fígados sadios e com cirrose}

O fígado tem a habilidade de regular o seu próprio tamanho de acordo com a "influência" trófica que recebe, ou seja, de acordo com o afluxo de um conjunto de substâncias e hormônios denominados genericamente de fatores hepatotróficos (FHs), muitos deles de origem esplâncnica, como a insulina, glucagon, aminoácidos e vitaminas, e certamente muitos outros ainda de origem desconhecida. Os FHs aumentam o tamanho do fígado por meio de estímulos regenerativos, esta capacidade regenerativa é atribuída no aumento do número de hepatócitos (PARRA et al., 1992, 1994, 1995, 1996).

A descoberta de que substâncias endógenas e exógenas influem no crescimento do fígado, abriu a perspectiva de se interferir diretamente no processo de regeneração (STARZL et al., 1975; STARZL et al., 1976; BAKER, 1985), com o intuito de melhora da função hepática e impedimento de progressão da fibrose (MATSUDA et al., 1995; MATSUDA et al., 1997; FUJIMOTO, 2000).

Dentre as principais substâncias hepatotróficas destacam-se os hormônios tireoideanos, a insulina, glucagon, nutrientes e drogas de ação hepatotrófica. Conforme sua origem, hepática ou extra-hepática, pode-se caracterizá-los como endógenos ou exógenos (MORSIANI et al., 1984). 
A insulina e o glucagon são hormônios importantes para o trofismo e metabolismo do parênquima hepático. O glucagon estimula a síntese de proteínas hepáticas, e este, juntamente com a insulina, atuam sinergicamente na regulação da regeneração hepática. A ausência de insulina provoca degeneração e morte dos hepatócitos em meio de cultura; porém a insulina não possui efeito mitogênico sobre os hepatócitos, mas potencializa o efeito de outros fatores de crescimento (KALIL; SPERB; LICHTENFELS, 1998; JESUS; WAITZBERG; CAMPOS, 2000; CORPECHOT et al., 2002).

Parra et al. (1992) estudaram o crescimento adicional de fígados sadios induzido por FHs; doses desta solução foram administradas com e sem hormônios e notaram que o grupo que recebeu a solução de FHs com insulina e glucagon apresentou aumento significante de $34,48 \%$ no crescimento da massa hepática quando comparado aos demais grupos; este dado mostra que é possível aumentar o tamanho do fígado sadio.

Parra et al. (1994) verificaram a estimulação de fígados de ratos sadios com os FHs. Observaram que a administração de FHs + insulina + glucagon induziu resposta hiperplásica nestes fígados; FHs + substituição da glicose por uma quantidade isocalórica de lipídeo emulsificado, não causou ação estimulante adicional; FHs + leite humano liofilizado aumentou a massa hepática para 41,05\%; FHs $+500 \mu \mathrm{g}$ de ácido fólico $+6,25 \mu \mathrm{g}$ de vitamina $\mathrm{B}_{12}+625 \mu \mathrm{g}$ de sulfato de zinco proporcionou o aumento da massa hepática para 41,63\%; FHs $+14,125 \mu \mathrm{g}$ de L-triiodotironina $\left(\mathrm{T}_{3}\right)$ proporcionou estimulação hiperplásica para $50,68 \%$ da massa hepática; e por último, notou que $\mathrm{FHs}+28,25 \mu \mathrm{g}$ de $\mathrm{T}_{3}$ promoveu grande estímulo regenerativo em fígados, de 50,74 foi para $85,91 \%$.

Ácido fólico, vitamina $\mathrm{B}_{12}$, zinco e hormônio da tireóide estão classicamente associados com a síntese de DNA e regeneração celular (BORGES; FERRINI; WAITZBERG, 1990), no fígado em particular.

Parra et al. (1995b) analisaram o aumento do tamanho do fígado através da estimulação em fígados de ratas sadias com FHs. Após término da aplicação dos fatores por 8 dias verificaram aumento percentual médio no tamanho do fígado de $114,16 \%$ se comparado ao grupo controle que foi de $0,0254 \%$; este aumento foi atribuído principalmente a formação de novas células; o conteúdo de DNA total em fígados também aumentou $60 \%$, sugerindo fortemente que o tratamento estimula a proliferação celular e o crescimento do fígado pela hiperplasia. 
Parra et al. (1996) observaram que a administração de FHs em fígados sadios reduz a quantidade relativa de colágeno no parênquima hepático em 37,46\%; em animais hepatectomizados também ocorre redução significante da quantidade deste colágeno. Em ambos os casos, a produção de tecido fibrocolagenoso ocorre em momentos diferentes comparados à recuperação da massa hepática como um todo; isto mostra que em ambos os casos ocorre um intervalo de tempo na recuperação dos componentes histológicos do fígado em regeneração, ou seja, o crescimento hepático de fígados sadios estimulados pelos FHs ocorre com uma diferença de tempo na produção de colágeno da matriz extracelular tal como ocorre no fígado após hepatectomia parcial.

Alóia et al. (2010) também notaram que a administração de FHs por via intraperitoneal aumentou o volume hepático, a proliferação dos hepatócitos e reduziu a densidade volumétrica do colágeno perisinusoidal.

A redução no colágeno em fígados sadios pode resultar um tecido hepático regenerado mais frágil prejudicando a função celular pela instabilidade nas relações intercelulares e provável dificuldade na circulação sanguínea (PARRA et al., 1996).

O uso de fatores hepatotróficos exógenos (fator de crescimento hepático e insulina) pela perfusão da veia porta também revelou melhoras na injúria hepática em animais cirróticos, minimizou danos na ultraestrutura dos hepatócitos, protegeu a função hepática e diminuiu a fibrose hepática em ratos com hipertensão portal (ZHONG-TAO et al., 2006).

Guerra et al. (2009) observaram aumento da massa hepática (11,8\%) nos animais com cirrose e tratados com FHs por 10 dias, associado à diminuição de 37,1\% na proporção volumétrica do colágeno. Após tratamento com os FHs os níveis sorológicos de ALT e AST também melhoraram, revelando recuperação da condição hepática; os níveis de GGT reduziram $43 \%$, indicando melhora de doença biliar se comparado ao grupo controle. Os níveis de expressão dos genes moduladores da MEC (colágeno $\alpha-1$, MMP-2, TGF- $\beta 1$ e TIMP-1) também diminuíram após tratamento o que promoveu redução do colágeno hepático.

Cogliati et al. (2010) também observaram em ratas com fibrose induzidas pela dimetilnitrosamina e tratados com FHs, aumento do fígado, que provavelmente foi modulado pelos elementos contidos na solução de FHs; estes animais apresentaram uma melhoria no quadro histopatológico devido à recuperação do parênquima hepático se comparado ao grupo controle; os FHs promoveram a recuperação da arquitetura microscópica hepática, parada e reversão do processo de fibrose; os níveis séricos de AST e ALT diminuíram por possível 
recuperação da integridade celular; os níveis séricos de albumina e de proteína total aumentaram, refletindo a ação benéfica da solução de FHs sobre a função das células do fígado, e houve redução do teor de colágeno da fibrose no parênquima hepático.

O uso de substâncias tróficas hepáticas é uma suposição de que o tamanho do fígado é regulado pela quantidade de sangue que chega através da veia porta e pela concentração dos componentes do sangue portal, informação sugerida para explicar o crescimento do fígado em transplantes hepáticos de tamanho pequeno (KAM et al., 1987; VAN THIEL et al., 1987; FRANCAVILLA et al., 1994; IKEGAMI et al., 2008). O contrário é observado quando a concentração dos componentes do sangue portal é reduzida pela má nutrição, e há acentuada diminuição no tamanho do fígado (PARRA et al., 1995a).

\subsubsection{Formulação dos fatores hepatotróficos}

A formulação da solução de FHs utilizados nesta pesquisa foi descrita em trabalhos prévios (PARRA et al., 1992, 1994, 1995, 1996) e está apresentada no capítulo Materias e Métodos (Ítem 4.3).

\subsection{INDICADORES BIOQUÍMICOS DE LESÃO HEPÁTICA}

Os testes de função hepática fornecem informações sobre o estado do fígado de um paciente, é um método útil para o reconhecimento das doenças que afetam a funcionalidade hepática, auxiliando no diagnóstico diferencial. Os indicadores bioquímicos para averiguar o estado geral do fígado e sistema biliar, se dividem em análise das principais enzimas hepáticas, provas de síntese e metabolismo hepático e em provas de transporte e excreção hepática (GOMES et al., 2008). 


\subsubsection{Principais enzimas hepáticas}

As principais enzimas hepáticas compreendem a aspartato aminotransferase (AST), alanina aminotransferase (ALT), fosfatase alcalina (ALKP) e gama-glutamil transferase (GGT). A aspartato aminotransferase (AST) é uma enzima que cataboliza aminoácidos permitindo que entrem no ciclo do ácido cítrico. Essa enzima faz a transaminação do grupo amino do aspartato para o $\alpha$-cetoglutarato, formando oxalato. Ela está relacionada com a integridade dos hepatócitos, porém não é específica do fígado, podendo ser encontrada no músculo cardíaco, rins, cérebro e células vermelhas do sangue (GIANNINI; TESTA; SAVARINO, 2005).

A alanina aminotransferase (ALT) catalisa a interconversão do grupamento amino da alanina para o $\alpha$-cetoglutarato formando piruvato e, portanto, desempenha importante função na gliconeogênese e no metabolismo de aminoácidos. A atividade da ALT é observada, principalmente, no fígado. Também pode ser encontrada em outros locais como músculos, coração, rins, cérebro e tecido adiposo, mas em fração muito menor (SCHINDHELM et al., 2006) de tal forma que é considerada um marcador hepato específico (BANKS, 1992). Por ser uma enzima citosólica o aumento da sua concentração indica permeabilidade da membrana e, portanto, morte celular (MURIEL; ESCOBAR, 2003). Assim, o aumento plasmático concomitante de ALT e de AST confirma a origem hepática da lesão. Apesar da ALT refletir injúria hepática, a AST tem uma correlação mais forte com a presença de fibrose (GRIGORESCU, 2006).

A proporção AST/ALT é utilizada como um marcador de maior sensibilidade e especificidade, em humanos. Pacientes normais apresentam valor de aproximadamente $0,8 \mathrm{e}$ este valor aumenta em estágio avançado de fibrose (MANNING; AFDHAL, 2008). Quando essa proporção é maior ou igual a 1, a cirrose pode ser caracterizada (CHEN et al., 2008). Uma proporção maior que 1,16, respectivamente apresentou $81 \%$ e $55 \%$ de sensibilidade e especificidade em identificar pacientes cirróticos que morreram no período de um ano (GRIGORESCU, 2006).

O grupo da fosfatase alcalina (ALKP) e gama-glutamil transferase (GGT) é um grupo de enzimas hepáticas que indicam obstrução do sistema biliar, a colestase (KAPLOWITZ; EBERLE; YAMADA, 1982; GIANNINI; TESTA; SAVARINO, 2005). 
A fosfatase alcalina (ALKP) é uma enzima que transporta metabólitos através das membranas celulares. Assim como a AST, a ALKP também não é específica do fígado, podendo ser observada nos ossos, nos intestinos, nos rins, na placenta e nos leucócitos. No fígado, ela está presente na superfície do epitélio dos ductos biliares e na membrana dos hepatócitos. A proliferação desses ductos aumenta a síntese e a liberação dessa enzima. Assim sendo, níveis aumentados de ALKP estão correlacionados ao grau de integridade do tecido hepático. A meia-vida da ALKP é de 1 semana e isso explica a sua lenta diminuição mesmo na fase de resolução da cirrose (GIANNINI; TESTA; SAVARINO, 2005).

A enzima gama-glutamil transferase (GGT) catalisa o metabolismo da glutationa e dos compostos conjugados a ela (ARIAS et al., 1994). A GGT faz a transferência do grupo $\gamma$ glutamil dos peptídeos para outros aminoácidos. Ela está presente nos hepatócitos e células do epitélio biliar, mas também é encontrada nos túbulos renais, pâncreas e intestino. Entretanto, sua utilização como teste de função hepática é justificada por sua alta sensibilidade em doenças do fígado. A GGT é um marcador de fibrose progressiva usado para identificar estágios mais avançados da doença, pois reflete anormalidades da estrutura e da função hepática. É uma indicadora de colestase mais específica do que a ALKP e a sua alta concentração plasmática é característica da cirrose. O mecanismo de alteração da GGT é semelhante ao da ALKP, ou seja, níveis plasmáticos aumentados de ambas as enzimas indicam origem hepatobiliar da lesão (GIANNINI; TESTA; SAVARINO, 2005; MANNING; AFDHAL, 2008; SCHUPPAN; AFDHAL, 2008).

\subsubsection{Provas de síntese e metabolismo hepático}

Os índices bioquímicos das proteínas hepáticas, albumina (ALB) e globulina (GLOB) são observados nas provas de síntese e metabolismo do fígado. A albumina (ALB) é uma proteína sintetizada no fígado, é constituída pela proteína total e pelas globulinas. A ALB contribui para o gradiente de concentração entre o sangue e o fluido extracelular, sendo responsável por cerca de $70 \%$ da pressão osmótica vascular, além de captar e transportar algumas substâncias, por exemplo, a bilirrubina livre (BANKS, 1992). Essa proteína 
encontra-se diminuída na cirrose avançada devido à diminuição da produção hepática (SCHUPPAN; AFDHAL, 2008).

A globulina (GLOB), juntamente com a ALB, compõe a TP plasmática (proteína total). A fração das GLOBs compreende as $\alpha, \beta$ e $\gamma$-globulinas. $O$ grupo das $\gamma$-globulinas é composto pelas imunoglobulinas e são sintetizadas nos órgãos do sistema reticuloendotelial. As demais são sintetizadas pelo fígado e, assim como a ALB, desempenham funções de transporte de substâncias (BANKS, 1992). Na cirrose hepática, a concentração de GLOB pode aumentar.

A redução da ALB e da TP é observada em enfermidades hepáticas, devido ao aumento da permeabilidade capilar, expansão do espaço extracelular, e pela maior proporção de albumina no compartimento extravascular (GERACI; MEDWAY, 1973). Kaibori et al. (1997) relata diminuição nos níveis da ALB e da TP em fígados cirróticos de ratos, esta redução indica falha ou dano à síntese protéica no fígado.

\subsubsection{Provas de transporte e excreção hepática}

Os níveis da bilirrubina total (TBIL) e proteína total (TP) possibilitam a verificação do transporte e excreção hepática. A bilirrubina é um produto formado a partir de eritrócitos velhos que são removidos da circulação por fagocitose. A hemoglobina é fragmentada em porção globina e porção heme, e seus componentes são reciclados. Quando esses componentes são separados, a globina é hidrolisada até aminoácidos, os quais voltarão à circulação. O ferro, localizado no interior do grupo heme, é liberado e volta aos estoques teciduais. O resíduo do grupo heme, denominado biliverdina, é transportado para o fígado onde é reduzido à bilirrubina. A bilirrubina, inicialmente, é insolúvel (bilirrubina nãoconjugada), mas torna-se solúvel pelo processo de biotransformação, realizado pela enzima glicuronil transferase, ao ser conjugada a um glicuronato. Esta forma da bilirrubina pode, então, entrar no hepatócito e a sua maior parte é secretada na bile. Uma pequena parte retorna à circulação, sendo excretada pelo rim na forma de urobilinogênio (BANKS, 1992; BANCROFT; GAMBLE, 2002). 
Em condições patológicas, a concentração plasmática de bilirrubina, tanto livre quanto conjugada aumenta, caracterizando a icterícia. As causas desse aumento podem ser decorrentes de aumento na destruição de eritrócitos, obstrução dos ductos biliares ou lesão de hepatócitos, de modo que mesmo as quantidades habituais de bilirrubina não são excretadas na bile (GUYTON; HALL, 2002). O teste da bilirrubina total (TBIL) compreende a fração conjugada e não-conjugada. É um teste específico de desordem hepática, visto que seu metabolismo é exclusivamente no fígado. Níveis elevados de bilirrubina conjugada pode haver suspeita de obstrução do ducto biliar.

O teste da proteína total (TP) avalia a concentração plasmática de proteínas (albumina + globulinas). A cirrose é uma condição patológica que provoca a redução dos níveis plasmáticos de proteínas. A incapacidade do hepatócito de sintetizar as proteínas em quantidade suficiente resulta na diminuição da pressão osmótica do plasma e formação de edema associado à afecção (GUYTON; HALL, 2002).

\subsection{ANTÍGENO NUCLEAR DE PROLIFERAÇÃO CELULAR (PCNA)}

O antígeno nuclear de proliferação celular (PCNA) foi identificado em 1978 inicialmente por Miyachi, Fritzler e Tan em pacientes com lúpus eritematoso sistêmico, denominaram PCNA porque a proteína foi observada no núcleo das células em divisão. $\mathrm{Na}$ mesma época, Bravo e Celis (1980) utilizaram dois géis de eletroforese dimensionais para identificar uma proteína sintetizada durante a fase $\mathrm{S}$ do ciclo celular, esta proteína foi denominada ciclina por estes pesquisadores. Trabalhos subseqüentes demonstraram que o PCNA e a ciclina é a mesma proteína (MATHEWS et al., 1984).

Hoje o termo PCNA é utilizado quando nos referimos à proteína sintetizada durante a fase $\mathrm{S}$ do ciclo celular, enquanto o termo ciclina, é usado para descrever uma família de proteínas envolvidas na regulação do ciclo celular (KELMAN, 1997). O PCNA é um componente essencial da maquinaria de replicação do DNA, funciona como uma proteína acessória para a DNA polimerase $\delta$ (pol delta), requerida no processo de síntese do DNA cromossomal e na síntese da DNA polimerase $\varepsilon$ (pol epsilon) (TAN et al., 1986; BRAVO et 
al., 1987; PRELICH et al., 1987). Além de replicação do DNA, as funções do PCNA estão associadas com outros processos celulares vitais, como o remodelamento da cromatina, reparo do DNA, a coesão das cromátides-irmãs e controle do ciclo celular (MAGA; HUBSCHER, 2003).

O ciclo celular envolve fases distintas, intérfase (fase $\mathrm{S}$ ) e mitose (M). A intérfase compreende três fases G1(antes da síntese), fase S e G2 (antes da mitose) que são pontos de checagem do ciclo celular. Na fase G1, ocorre a síntese de RNA e de proteínas que recuperam o volume celular anteriormente reduzido na mitose. $\mathrm{Na}$ fase $\mathrm{S}$, ocorre a duplicação do material genético. $\mathrm{Na}$ fase $\mathrm{G} 2$, as células acumulam energia para ser usada durante a mitose, e sintetizam tubulina para formar os microtúbulos do fuso mitótico. $\mathrm{Na}$ fase $\mathrm{M}$, ocorre a divisão de todo o componente celular em duas células idênticas. As células que saem do ciclo celular e não se renovam ficam em estado de repouso denominado fase G0 (GABRIEL, 2007) (Figura 11).

Os pontos de checagem celular ocorrem durante os finais das fases G1 e G2 e servem para as células completarem a replicação ou para reparar os danos antes da progressão do ciclo na entrada na mitose (CLARKE; ALLAN, 2009).

Muitas proteínas localizadas dentro do citoplasma controlam o ciclo celular, as ciclinas (subunidades reguladoras), e as ciclinas dependentes de quinases (CDKS - cyclin dependent kinases, subunidades catalíticas). Uma ciclina se associa com uma CDK e forma um complexo denominado CDKs-ciclina. Se um problema com o ciclo celular é detectado, a ativação do complexo CDKs-ciclina não é completada, se não houver problemas dentro da célula, então o complexo é ativado (GABRIEL, 2007) (Figura 11).

Há quatro famílias de ciclinas que são responsáveis pela ativação das CDKs em diferentes estágios do ciclo celular, ciclinas D (D1, D2 e D3), ciclinas E (E1 e E2), ciclinas A (A1 e A2), e ciclinas B (B1, B2 e B3). Há também basicamente quatro tipos de CDKs que regulam o ciclo celular $(\mathrm{CDK} 1=\mathrm{Cdc} 2, \mathrm{CDK} 2, \mathrm{CDK} 4$ e CDK6). A atividade $\mathrm{CDK}$ é regulada positiva e negativamente em múltiplos níveis, além da ativação pela junção com ciclina, incluem a fosforilação e desfosforilação de resíduos específicos de aminoácidos, localização subcelular e inibição mediada pela interação proteína-proteína (MAGA; HUBSCHER, 2003).

De acordo com o modelo predominante de controle do ciclo celular em células de mamíferos, o complexo CDK4/CDK6-ciclina D e o complexo CDK2-ciclina E são sequencialmente necessários para promover a entrada de células quiescentes no ciclo celular, 
a progressão da fase $\mathrm{G} 1$ para a fase $\mathrm{S}$ em resposta à estimulação mitogênica. Estes complexos induzem o fator de transcrição E2F necessário para a entrada da célula na fase $\mathrm{S}$ (MASSAGUÉ, 2004; SANTAMARIA; ORTEGA, 2006) (Figura 11). O principal papel do PCNA é na fase $\mathrm{S}$, onde a forquilha de replicação pode parar em locais onde haja DNA danificado (MAGA; HUBSCHER, 2003).

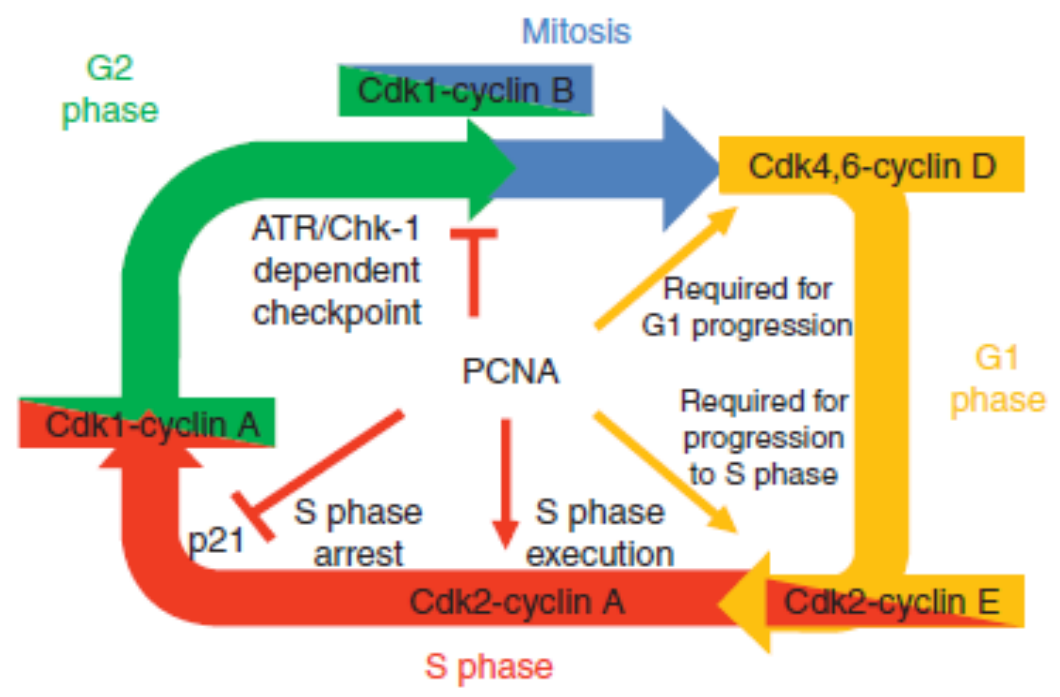

Fonte: (MAGA; HUBSCHER, 2003)

Figura 11 - Modelo de interação do PCNA com proteínas que regulam o ciclo celular

Dentre os marcadores de proliferação celular, o antígeno nuclear de proliferação celular (PCNA) é um dos mais utilizados na técnica de imuno-histoquímica, tem um aparecimento cíclico durante as diferentes fases do ciclo, entretanto esta proteína é altamente expressa durante a fase S do ciclo celular. O PCNA se liga aos complexos CDKs-ciclinas assim como aos inibidores do ciclo celular como p21 (MAGA; HUBSCHER, 2003). Danos ao DNA estimulam a ativação da proteína p53, que leva à transcrição da proteína p21, que pode inibir os complexos CDKS-ciclinas e PCNA para impedir a entrada da célula na fase S.

A proteína p53 é um fator de transcrição e um componente chave para a resposta celular mediante ao dano. Exposição da célula a algum dano causa aumento no nível da p53 na forma ativa. Altos níveis de p53 afetam a transcrição de vários genes e levam o ciclo celular à suspensão. Mediante a ausência ou a mutação de p53, a expressão de PCNA não será 
mais inibida e consequentemente o índice de células em proliferação será maior (KELMAN, 1997).

O PCNA por ser um marcador de proliferação celular, está expresso no processo de regeneração hepática e na hepatocarcinogênese (MEHTA, 1995). Foi demonstrado aumento na positividade dos hepatócitos ao PCNA em ratos tratados com $\mathrm{CCl}_{4}$ (WANG et al., 1999; CHAN et al., 2010), porém este índice foi significantemente inibido em animais induzidos a fibrose hepática e tratados com inhame liofilizado, por diminuir a severidade da lesão hepática por meio da regulação do crescimento celular e pela síntese de DNA.

Os índices do PCNA, em fígados de ratos após estabelecimento da cirrose pela TAA também aumentaram. A TAA estimulou a proliferação hepática, um dia após o término da aplicação do agente hepatotóxico. Após 30 e 60 dias de retirada da TAA a regeneração do fígado foi significativamente desacelerada e permanceu até 120 dias, ou seja, a TAA inicialmente faz um papel na estimulação da regeneração hepática, e sua retirada resulta em regeneração desacelerada (GU et al., 2010).

\subsection{MODELO EXPERIMENTAL DE CIRROSE HEPÁTICA PELA TIOACETAMIDA}

Até 1943, a tioacetamida (TAA) era usada inicialmente como fungicida em lavouras de laranja. Em 1948, descobriu-se que a administração crônica desta substância levava à cirrose hepática e hepatocarcinomas (MUÑOZ TORRES et al., 1991; DAVID et al., 2002). Hoje em dia, a TAA é utilizada nas indústrias do couro, papel e têxtil, e empregada como acelerador na vulcanização de borracha e estabilizador de combustíveis (WANG et al., 2000).

A TAA é um agente hepatotóxico bem conhecido em vários modelos animais depois de prolongada administração (MOREIRA et al., 1995; DAVID et al., 2002), e requer ativação metabólica para que seu efeito seja tóxico. Os produtos resultantes da sua biotransformação são S-óxido de tioacetamida e S-dióxido de tioacetamida (Figura 12). O efeito citotóxico dessa droga é atribuído ao último metabólito, um composto instável altamente reativo que se liga covalentemente às macromoléculas teciduais (CHILAKAPATI et al., 2005). 


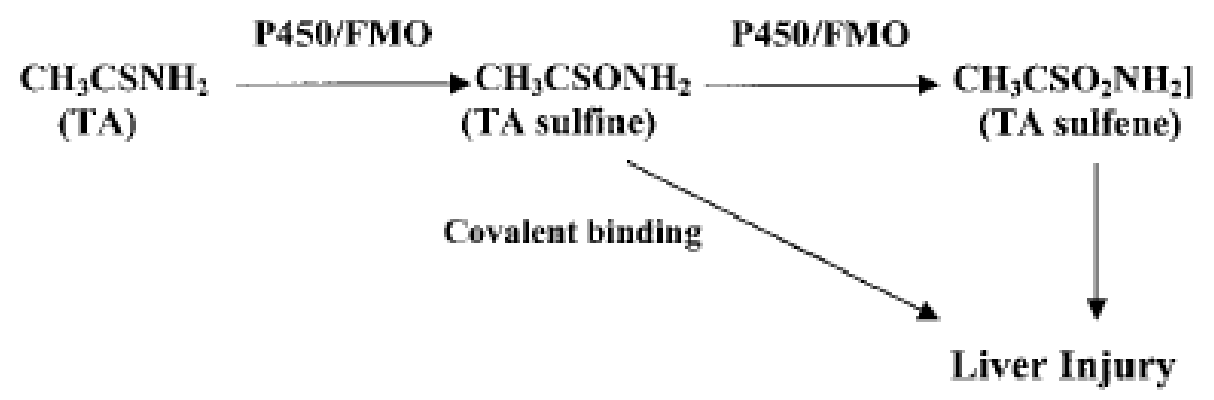

Fonte: (RAMAIAH; APTE; MEHENDALE, 2001)

Figura 12 - Esquema ilustrativo da metabolização da tioacetamida

A ativação da TAA é ocasionada pela ação catalítica do complexo microssomal citocromo P-450, localizado no retículo endoplasmático liso. O sistema enzimático citocromo P-450 compreende várias isoenzimas das quais a CYP2E1 (Cytochrome P450 2E1) parece ser a que está mais envolvida na metabolização da TAA (WANG et al., 2000). Esta isoenzima é a principal família de citocromos P-450 do fígado dos mamíferos, desempenhando papel crucial no metabolismo, toxicidade e carcinogênese de xenobióticos (RAMAIAH; APTE; MEHENDALE, 2001; CARO; CEDERAUM, 2005), além de metabolizar vários outros compostos de baixo peso molecular (CHILAKAPATI et al., 2005).

A TAA reduz a atividade antioxidante; acentua a peroxidação lipídica e lipoprotéica no fígado; altera o ciclo da uréia, estabelecendo uma condição de estresse oxidativo que leva à necrose celular (DAVID et al., 2002; TÚNEZ et al., 2005). Os radicais livres gerados por esta via oxidativa provocam aumentos no cálcio citosólico, inibição da glutationa e redução dos grupos tiol $(-\mathrm{SH})$, afetando severamente as células da região acinar pericentral e levando à morte celular. A concentração intracelular de glutationa e os níveis de tióis atuam sobre o DNA, modulando a síntese e protegendo-o do dano oxidativo (SANZ et al., 1998; ZARAGOZA et al., 2000). A toxicidade da TAA leva à destruição do parênquima com rompimento de endomembranas e perda da matriz citoplasmática (MUÑOZ TORRES et al., 1991).

A cirrose induzida por TAA em ratos leva a uma menor mortalidade (35\%) em relação ao $\mathrm{CCl}_{4}(50 \%)$ (LI; BENJAMIN; ALEXANDER, 2002). A fibrose hepática e os nódulos regenerativos são mais proeminentes e o padrão histológico é mais próximo ao da cirrose humana (LALEMAN et al., 2006). A lenta deposição de colágeno tem sido apontada como uma desvantagem no uso da TAA em relação ao $\mathrm{CCl}_{4}$, e no geral, a cirrose se estabelece a 
partir da $10^{\mathrm{a}}$ semana de tratamento (AL-BADER et al., 2000; SPIRA et al., 2002). O desenvolvimento tardio da doença é visto como mais uma das características da TAA em reproduzir adequadamente o estado crônico da doença hepática (MASUMI et al., 1999). Para que a cirrose se desenvolva no humano, geralmente são necessários anos de exposição ao agente tóxico.

A administração crônica dessa hepatotoxina provoca perda de peso, necrose celular, regeneração de hepatócitos, fibrose progressiva levando a cirrose e proliferação de ductos biliares (MOREIRA et al., 1995; FONTANA et al., 1996; AL-BADER et al., 2000; JEONG et al., 2001).

Este agente tóxico pode ser administrado por diferentes vias, oral (na água ou na ração ingerida), por intubação intragástrica, ou por injeções subcutâneas ou intraperitoneais (FONTANA et al., 1996). A administração de TAA através da água do bebedouro consiste em um método não invasivo, satisfatório e fácil na indução da cirrose em grande número de animais (LI; BENJAMIN; ALEXANDER, 2002), mas, à medida que a cirrose instala-se e compromete o fígado do animal, ele apresenta perda de apetite e redução na ingestão da água com o fármaco (até $50 \%$ menos do que os animais controle), diminuindo a eficiência do tóxico (MOREIRA et al., 1995; FONTANA et al., 1996; GEORGE et al., 2001). E podem ocorrer falhas e variações no processo de indução, pois não é possível controlar a dosagem de tóxico ingerida por cada animal ingere, e pode levar resultados heterogêneos durante o desenvolvimento do quadro patológico.

Após um determinado período de administração da TAA o animal adquire certo grau de resistência à droga, levando a uma variação na sensibilidade hepática (LI; BENJAMIN; ALEXANDER, 2002). Dois fatores contribuem para esta variação de resposta, o envelhecimento do animal e a redução do citocromo P-450, devida ao dano celular. As diferenças na atividade do sistema enzimático são dependentes da idade, apresentando aumento dos 2 aos 12 meses, nos ratos, e diminuindo na senescência (ZARAGOZA et al., 2000).

A sensibilidade hepática à TAA se reduz com o tempo e, assim, é sugerido que as doses sejam ajustadas de acordo com as oscilaçoes de peso dos animais. Esse método resultaria em aumento no rendimento da indução do quadro cirrótico e redução expressiva da mortalidade (LI; BENJAMIN; ALEXANDER, 2002). 


\section{MATERIAIS E MÉTODOS}

Abaixo, seguem os tópicos referentes à metodologia utilizada no estudo dos efeitos do tratamento com os fatores hepatotróficos, na cirrose desenvolvida em ratas pela administração da tioacetamida.

\subsection{ANIMAIS}

Foram utilizadas setenta e cinco ratas (Rattus norvegicus), linhagem Wistar, com 2 meses de idade e peso corpóreo inicial de 191,6 \pm 9,4 g, provenientes do Biotério do Departamento de Patologia da Faculdade de Medicina Veterinária e Zootecnia da Universidade de São Paulo - USP. Durante o período experimental, todos os animais permaneceram alojados em caixas de polipropileno (5 animais por caixa), sob condições ambientais controladas de temperatura $\left(22-24^{\circ} \mathrm{C}\right)$ e iluminação (ciclo de 12 horas claro/12 horas escuro); recebendo diariamente ração comercial (Nuvital) e água ad libitum. Este trabalho foi aprovado pela Comissão de Bioética da Faculdade de Medicina Veterinária e Zootecnia da Universidade de São Paulo, conforme os protocolos n ${ }^{\text {os }} 1121 / 2007$ e 1361/2008.

\subsection{MODELO DE INDUÇÃO DA CIRROSE HEPÁTICA PELA ADMINISTRAÇÃO DA TIOACETAMIDA}

A metodologia de indução da cirrose pela administração da tioacetamida seguiu o protocolo determinado por Kwon et al. (1990) e Oe et al. (2003). A tioacetamida (TAA) foi diluída em solução salina $0,9 \%$ na concentração de $4 \%$ e administrada intraperitonealmente na 
dose de $200 \mathrm{mg} / \mathrm{Kg}, 3$ vezes por semana, durante 14 semanas. Os animais foram pesados no momento de cada administração para o cálculo preciso da dose. A cada período de 24 dias pós-início da indução, a dose sofreu acréscimo de 10\%. Este ajuste na dose teve a finalidade de evitar a adaptação dos animais à droga.

\subsection{COMPOSIÇÃO E ADMINISTRAÇÃO DA SOLUÇÃO DOS FATORES HEPATOTRÓFICOS}

A composição da solução de Fatores Hepatotróficos (FHs) e a quantidade de cada componente estão relacionadas no quadro 1. A solução dos fatores foi preparada pelo Laboratório Fórmula Medicinal - Suporte Nutricional e Manipulação e fornecida em bolsa plástica, sem a adição das vitaminas e dos hormônios triiodotironina, insulina e glucagon. As vitaminas foram fornecidas pelo mesmo laboratório; a insulina e o glucagon adquiridos em farmácia popular. Estes três componentes foram injetados na bolsa antes da administração. $\mathrm{O}$ hormônio triiodotironina foi formulado (diluído em álcool etílico 100\%) e fornecido pelo Laboratório Power Vet - Laboratórios de Fórmulas Veterinárias. No momento da administração, o hormônio foi adicionado separadamente na dose de 2,26 $\mu \mathrm{g} / 200 \mathrm{~g}$ de peso/dia, em cada seringa contendo a solução de FHs. Os animais submetidos ao tratamento foram pesados antes de cada administração e receberam a solução em duas aplicações intraperitoneais, com intervalo de $12 \mathrm{hs}$, na dose de $40 \mathrm{~mL} / \mathrm{Kg}$ por dia, por 12 dias. 


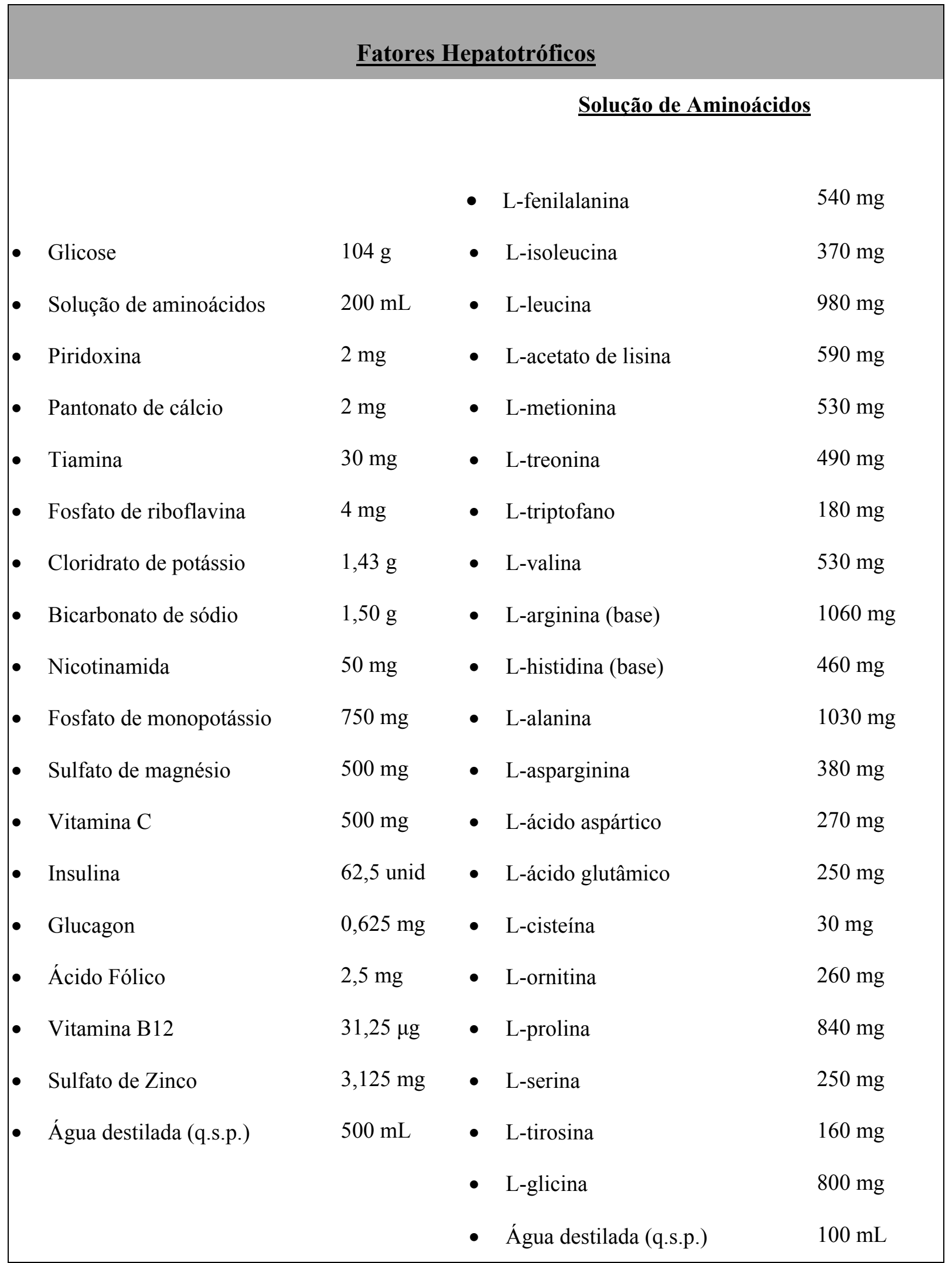

Quadro 1 - Composição da solução de Fatores Hepatotróficos 


\subsection{DELINEAMENTO EXPERIMENTAL}

Serão descritos a seguir a formação dos grupos, os procedimentos de biópsia hepática, coleta de sangue, acompanhamento da evolução dos sinais clínicos, os procedimentos adotados na eutanásia, na coleta do material para análise histopatológica; os parâmetros para análise da bioquímica sérica, das alterações celulares e teciduais. Serão apresentados ainda, os parâmetros para a avaliação do estadiamento da cirrose hepática, a determinação do índice de atividade histológica, para a análise morfométrica do colágeno; a descrição das técnicas de imunomarcação e de PCR em tempo real.

\subsubsection{Formação dos grupos}

As ratas foram individualizadas por marcação colorimétrica com ácido pícrico (cabeça, dorso, cauda, lateral esquerda e lateral direita), sendo cada animal marcado em uma única região do corpo. Posteriormente foram submetidas à indução da cirrose pela tioacetamida (Figura 13 A) e divididas em quatro grupos identificados como: $\mathrm{FH}(\mathrm{n}=15)$ e o seu grupo controle $(\mathrm{CT}, \mathrm{n}=30)$; e $\mathrm{FH}^{+60 \mathrm{~d}}(\mathrm{n}=15)$ e seu controle $(\mathrm{CT}, \mathrm{n}=15)$. A nomeação dos grupos respeitou à presença $(\mathrm{FH})$ ou ausência $(\mathrm{CT})$ de tratamento e ao tempo transcorrido entre o final do tratamento e a eutanásia. Neste último parâmetro, no grupo tratado por 12 dias e eutanasiado imediatamente após o término do tratamento $(\mathrm{FH})$, não foi colocada nenhuma indicação de tempo e o grupo eutanasiado 60 dias pós-tratamento, recebeu a indicação $+60 \mathrm{~d}$ $\left(\mathrm{FH}^{+60 \mathrm{~d}}\right)$.

No grupo FH os animais foram submetidos à indução da cirrose pela TAA e um dia após o período de indução foi realizada a coleta de sangue e biópsia para acompanhamento do quadro histopatológico. A partir do $7^{\circ}$ dia pós-biópsia, este grupo foi submetido ao tratamento com os FHs por 12 dias. Imediatamente após o término do tratamento foram realizadas nova coleta de sangue e a eutanásia dos animais (Figura 13 B). 
Os animais do grupo que foi utilizado como controle do grupo $\mathrm{FH}$, foram submetidos à coleta de sangue um dia antes do início da indução da cirrose pela TAA e foram eutanasiados (Figura $13 \mathrm{C}$ ) no mesmo dia do grupo $\mathrm{FH}$, estes animais não foram tratados com os FHs.

Os animais do grupo $\mathrm{FH}^{+60 \mathrm{~d}}$ foram submetidos à indução (14 semanas) e tratamento (12 dias) nos mesmos padrões do grupo $\mathrm{FH}$. Entretanto, no $21^{\circ}$ dia pós-indução sofreram coleta de sangue e biópsia hepática, para acompanhamento do quadro histopatológico, permanecendo sem manipulação por 60 dias. No final deste período, foram realizadas nova coleta de sangue e a eutanásia dos animais. Este grupo teve a finalidade de avaliar, se os possíveis efeitos do tratamento com os FHs sobre a cirrose seriam definitivos e/ou quais efeitos permaneceriam por 60 dias pós-tratamento (Figura $13 \mathrm{D}$ ).

No grupo utilizado como controle $(\mathrm{CT})$ do $\mathrm{FH}^{+60 \mathrm{~d}}$ os animais foram submetidos à indução da cirrose, não foram tratados com os FHs e um dia após o término da indução sofreram coleta de sangue e biópsia, permanecendo sem manipulação até o momento da eutanásia. A eutanásia foi realizada no mesmo dia do grupo $\mathrm{FH}^{+60 \mathrm{~d}}$, após nova coleta de sangue (Figura $13 \mathrm{E})$. 
A)

\begin{tabular}{|c|c|c|c|c|c|}
\hline TAA & $\begin{array}{c}\uparrow 10 \% \\
\text { TAA }\end{array}$ & $\begin{array}{c}\uparrow 10 \% \\
\text { TAA }\end{array}$ & $\begin{array}{c}\uparrow 10 \% \\
\text { TAA }\end{array}$ & I & $\begin{array}{c}\text { Início dos procedimentos de acordo com o grupo } \\
\text { experimental }\end{array}$ \\
& & \multicolumn{1}{|c|}{$14 \mathrm{~s}$} & $1 \mathrm{~d}$
\end{tabular}

B)

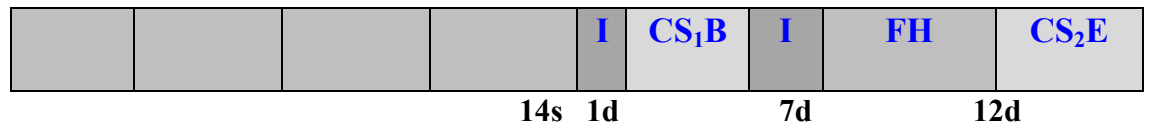

C)

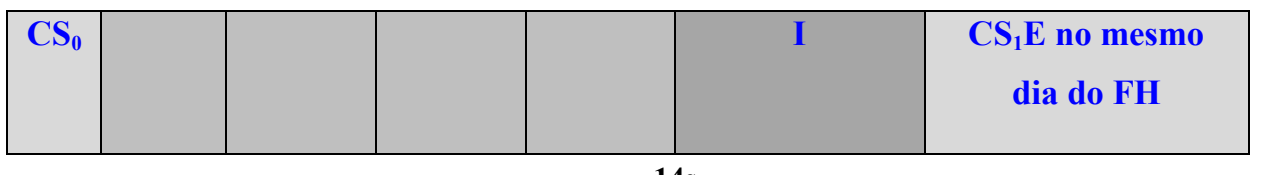

14s

D)

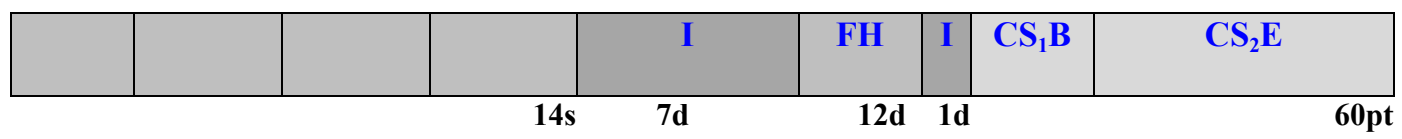

E)

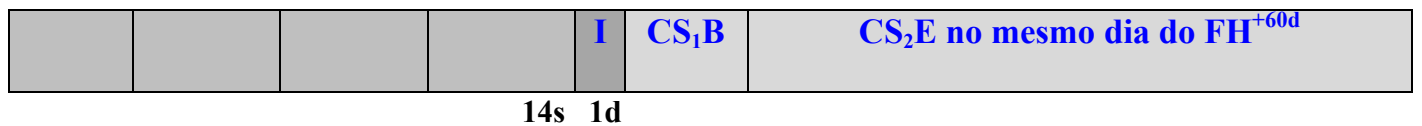

Figura 13 - Esquema do delineamento experimental em cada grupo submetido ou não ao modelo de indução da cirrose pela administração da tioacetamida e tratados ou não com os FHs: A) indução pela tioacetamida; B) grupo $\mathrm{FH}$; C) grupo $\mathrm{CT}$ do $\mathrm{FH}$; D) grupo $\mathrm{FH}^{+60 \mathrm{~d}}$ e E) grupo $\mathrm{CT}$ do $\mathrm{FH}^{+60 d}$. $\mathbf{C S}_{\mathbf{0}}$, coleta de sangue antes do início da indução da cirrose com a TAA; $\mathbf{C S}_{1} \mathbf{B}$, primeira coleta de sangue e biópsia pós-indução com a TAA; $\mathbf{C S}_{1} \mathbf{E}$, primeira coleta de sangue e eutanásia; $\mathbf{C S}_{2} \mathbf{E}$, segunda coleta de sangue e eutanásia; d, dias; pt, póstratamento; s, semanas; TAA, indução da cirrose pela administração da tioacetamida; $\uparrow \mathbf{1 0 \%}$ TAA, aumento de $10 \%$ da dose de tioacetamida

Durante os períodos de indução (14 semanas), tratamento (12 dias) e pós-tratamento (60 dias) todos os animais foram pesados semanalmente até o momento da eutanásia. 


\subsubsection{Biópsia hepática e coleta de sangue}

Foi realizada apenas uma biópsia nos grupos $\mathrm{FH}, \mathrm{FH}^{+60 \mathrm{~d}}$ e seu controle, durante todo o período experimental. O controle do grupo $\mathrm{FH}$, não foi biopsiado. Os grupos $\mathrm{FH}$ e o $\mathrm{CT}$ do grupo $\mathrm{FH}^{+60 \mathrm{~d}}$ foram biopsiados 1 dia após a indução com a TAA. A biópsia do grupo $\mathrm{FH}^{+60 \mathrm{~d}}$ foi realizada imediatamente após o término do tratamento com os FHs. Os dados obtidos foram utilizados em comparações intra e inter grupos.

Todo o material e campo cirúrgicos foram cuidadosamente mantidos limpos e esterilizados. Os animais foram anestesiados através de anestesia inalatória utilizando-se o anestésico isofluorano (Isoforine, Cristália ${ }^{\circledR}$ ). Este anestésico foi administrado através do circuito de Magill em oxigênio 100\%, vinculado a um cilindro de oxigênio (Oxigênio Medicinal), conectados a um ventilador próprio para insensibilização (K. Takaoka Ventilador 674).

Antes do procedimento cirúrgico, a profundidade da anestesia foi avaliada pela verificação das frequências cardíaca e respiratória, assim como pelo grau de relaxamento muscular e reflexos interdigitais (ausência de reflexos profundos). Em seguida, as regiões torácica e abdominal foram tricotomizadas, sendo realizada a coleta sanguínea através de punção cardíaca, seguida da biópsia hepática em cunha. A punção cardíaca foi realizada com agulha 0,70x30 mm (BD Plastipak), sendo retirados aproximadamente $1 \mathrm{~mL}$ por animal. Cada grupo sofreu duas coletas de sangue; a primeira logo após a indução $\left(\mathrm{CS}_{1} \mathrm{~B}\right)$ e a segunda no dia da eutanásia $\left(\mathrm{CS}_{2} \mathrm{E}\right)$; exceto o controle $(\mathrm{CT})$ do grupo $\mathrm{FH}$, que foi submetido à coleta de sangue antes do início da indução $\left(\mathrm{CS}_{0}\right)$ e no dia da eutanásia $\left(\mathrm{CS}_{1} \mathrm{E}\right)$. Os dados obtidos com as coletas de sangue realizadas no momento da biópsia foram comparados intra e intergrupos.

A biópsia em cunha foi iniciada a partir da realização de uma incisão mediana subxifóidea da pele e musculatura (aproximadamente 1,5 cm) com auxílio de um bisturi. Com a abertura completa de pele e musculatura foi realizada pressão lateral nas últimas costelas para a expulsão do lobo hepático lateral esquerdo. A biópsia em cunha foi realizada com o auxílio de tesoura ponta fina, sendo colocado no local da incisão o adesivo veterinário para tecido, vetbond (Vetbond ${ }^{T M} 3 M$ ) para estancar o sangramento. O lobo hepático foi recolocado dentro para a cavidade abdominal logo após o sangramento ter cessado. As incisões na musculatura e na pele foram suturadas separadamente, com pontos do tipo simples separado 
(fio de sutura 2/0, 3x45 mm e agulha 1/2.2,6 cm HR26; Laboratórios B. Braun S.A.). Durante todo o procedimento cirúrgico foi gotejada solução fisiológica sobre a mucosa do globo ocular, evitando o seu ressecamento.

Imediatamente após o procedimento cirúrgico foram injetados intraperitonealmente o analgésico sulfato de morfina (DIMORF SP, Cristalia), dosagem única de $4 \mathrm{mg} / \mathrm{Kg}$ de peso corpóreo e o antibiótico benzilpenicilina benzatina (1.200.000 UI, suspensão injetável benzetacil $^{\circledR}$, Eurofarma Laboratórios), dosagem de $6.000 \mathrm{UI} / 200 \mathrm{~g}$ de peso por dia, durante dois dias. As doses foram calculadas com base na menor dose administrada em crianças, 300.000 a $600.000 \mathrm{UI} / 27 \mathrm{Kg}$. Foi aplicado aproximadamente $1 \mathrm{~mL}$ de soro fisiológico na região subcutânea dorsal, para o reajuste da perda dos fluídos corporais. Após a biópsia os animais foram mantidos à $24^{\circ} \mathrm{C}$ até recuperação da hipotermia causada pelo anestésico e procedimento cirúrgico.

\subsubsection{Avaliação dos sinais clínicos e acompanhamento da mortalidade}

Durante a indução da cirrose pela administração da TAA os animais foram observados quanto à manifestação de sinais clínicos como: presença de piloereção, amarelamento da pelagem, alopecia, secreção porfirinêmica da glândula de Harder, flacidez da pele, posição álgica, pouca responsividade à manipulação, diarréia, bem como, quanto à frequência de mortalidade.

\subsubsection{Eutanásia}

Ao final de cada protocolo experimental, os animais foram anestesiados, o sangue foi colhido por pulsão cardíaca e os animais eutanasiados com dose excessiva de anestésico. Em seguida foram pesados para o cálculo dos índices biométricos; as vísceras (pulmões, coração, 
rins, baço e trato digestório completo) e a carcaça foram pesadas separadamente e o fígado removido e pesado individualmente.

O volume do fígado foi calculado pela imersão do órgão em um recipiente contendo líquido, sendo seu volume equivalente ao peso do deslocamento da água. Após este procedimento, fragmentos de cada lobo hepático (Figura 14) foram removidos e fixados para a realização das colorações histológicas e análises moleculares.

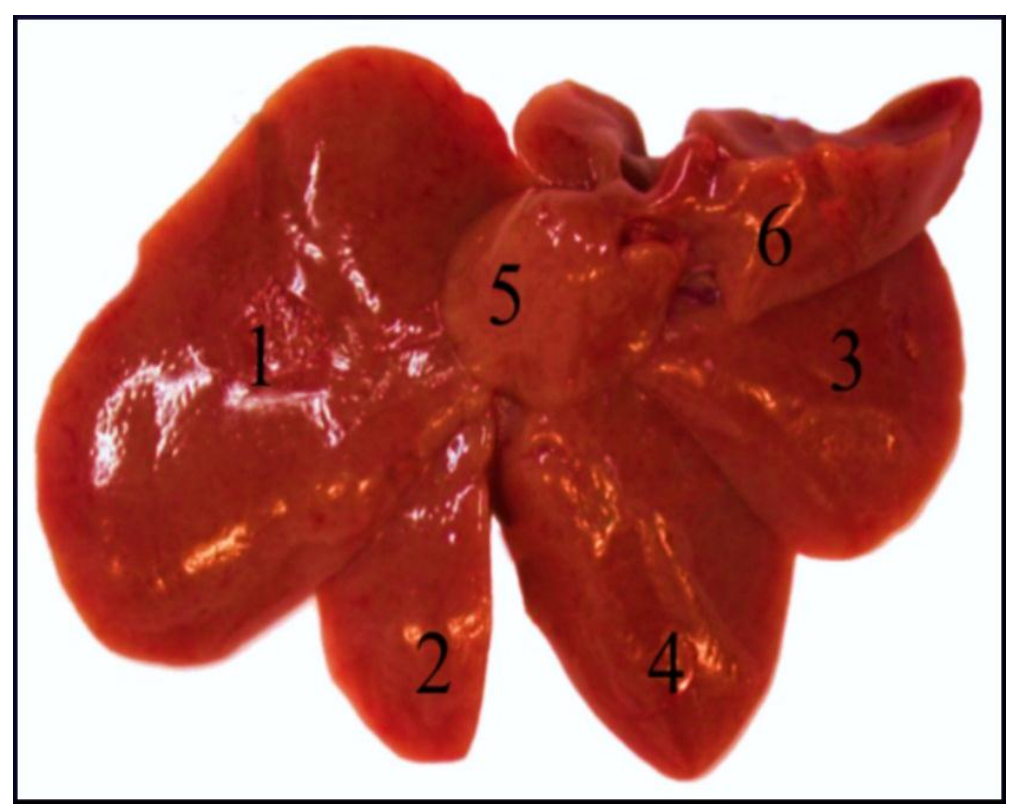

Figura 14 - Aspecto dorsal de um fígado de rato mostrado os diferentes lobos hepáticos. 1: lateral esquerdo; 2: medial esquerdo; 3: lateral direito; 4: medial direito; 5: processo papilar do lobo caudato e 6: processo caudato do lobo caudato

\subsubsection{Coleta do sangue para análise bioquímica}

Todas as amostras de sangue colhidas foram transferidas para microtubos (MCT150C, Homo-polymer, Oxygen Scientific) contendo heparina (Heparina Sódica 5000UI/0,25 $\mathrm{ml}$, Liquemine ${ }^{\circledR}$, Roche) e mantidas em gelo. Após o término da eutanásia, foram centrifugadas (Microcentrifugue, SD 110VAC, Revan Cientific) por 5 minutos, a $6.000 \mathrm{rpm}$, 
para obtenção do plasma, transferidas para tubos de $12 \times 45 \mathrm{~mm}$ (Solumix) e estocadas em freezer $-80^{\circ} \mathrm{C}$ para posterior análise.

\subsection{FIXAÇÃO E PROCESSAMENTO DO MATERIAL BIOLÓGICO}

O tecido hepático foi seccionado e submetido à fixação e conservação de acordo com cada técnica de análise a ser realizada (Quadro 2). Imediatamente após a remoção e pesagem do fígado, fragmentos dos lobos medial esquerdo e lateral direito foram colhidos e congelados em nitrogênio líquido $\left(\mathrm{N}_{2}\right)$ e mantidos a $-80^{\circ} \mathrm{C}$ até o momento da realização da técnica de RTPCR (reação em cadeia de polimerase em tempo real).

Amostras de aproximadamente $5 \mathrm{~mm}$ de diâmetro do lobo medial direito foram fixadas em metacarn (60\% metanol, 30\% clorofórmio e 10\% ácido acético) e Bouin (formol, $50 \mathrm{~mL}$; ácido acético, $20 \mathrm{~mL}$; ácido pícrico q.s.p. $500 \mathrm{~mL}$ ), neste último fixador foram também fixadas as biópsias hepáticas colhidas durante o período experimental. O material fixado em metacarn permaneceu por 12 horas, após este período o fixador foi trocado por álcool $95^{\circ}$ e o material processado rotineiramente para inclusão em paraplast (Erv-plast parafina histológica, Easy Path, Erviegas). Foram confeccionadas lâminas com cortes de 5 $\mu \mathrm{m}$ de espessura, utilizadas nas técnicas de imuno-histoquímica (PCNA, $\alpha$-actina de músculo liso, colágeno 1 e 3) e coloração de ácido periódico de Schiff (PAS).

O material fixado em Bouin (biópsias e eutanásia) permaneceu neste fixador por 6 horas, após este período sofreu sucessivas lavagens em álcool $70^{\circ} \mathrm{C}$ para remoção do excesso de ácido pícrico, e posteriormente foi processado rotineiramente para inclusão em paraplast. Foram confeccionadas lâminas com cortes de $5 \mu \mathrm{m}$ de espessura utilizadas nas colorações de hematoxilina e eosina (HE), alcian blue e picrossírius.

Amostras de aproximadamente $2 \mathrm{~mm}$ de diâmetro do lobo lateral esquerdo foram fixadas em McDowell (solução A, paraformaldeído a 4\%; solução $\mathbf{B}$, glutaraldeído a 10\%; solução C, Tampão Fosfato (pH 7.2) q.s.p. $100 \mathrm{~mL}$ ) e processadas rotineiramente para inclusão em historesina, contendo hidroxietil metacrilato (Leica Historesin, embedding Kit, Leica Microsystems), acrescida de agente endurecedor (Historesin $^{T M}$, Hardner, Leica 
Microsystems). Foram confeccionadas lâminas com cortes de $3 \mu \mathrm{m}$ de espessura utilizadas nas colorações de azul da Prússia.

O quadro 2 sumariza as técnicas e/ou colorações, bem como, os diferentes fixadores exigidos por cada uma delas.

\begin{tabular}{|c|c|c|}
\hline Lobo Hepático & Fixador & Técnica/Coloração \\
\hline 1- Lobo hepático lateral esquerdo & McDowell & azul da Prússia \\
\hline 2- Lobo hepático medial esquerdo & $\mathrm{N}_{2}$ líquido & RT-PCR \\
\hline 3- Lobo hepático lateral direito & $\mathrm{N}_{2}$ líquido & RT-PCR \\
\hline 4- Lobo hepático medial direito & Metacarn & IHQ e PAS \\
& Bouin & HE, alcian blue e picrossírius \\
\hline
\end{tabular}

Quadro 2 - Relação dos lobos hepáticos destinados às técnicas de coloração e análise específicas, bem como dos fixadores por elas exigidos. IHQ: imuno-histoquímica

\subsection{BIOMETRIA - CÁLCULO DOS ÍNDICES RELATIVOS}

Os índices relativos foram calculados através dos pesos em gramas e do volume dos fígados de todos os animais obtidos no momento da eutanásia.

A densidade do fígado $\left(\mathrm{cm}^{3} / \mathrm{g}\right)$ foi calculada dividindo-se o peso do fígado $(\mathrm{g})$ pelo volume do fígado $\left(\mathrm{cm}^{3}\right)$; o índice-vísceras/peso final (\%) foi calculado multiplicando-se o peso das vísceras (g) x 100 / (dividido) pelo peso final do animal (g); o índice hepato/corporal (\%) foi realizado multiplicando-se o peso do fígado (g) x $100 /$ (dividido) pelo peso da carcaça do animal (g); e o hepatossomático (\%), multiplicando-se o peso do fígado (g) x 100, dividido pelo peso final do animal $(\mathrm{g})$. 


\subsection{ANÁLISE BIOQUÍMICA SÉRICA}

Os efeitos dos tratamentos (TAA e FHs) sob a função e/ou lesão hepáticas foram avaliados pela mensuração dos níveis plasmáticos de indicadores específicos como as enzimas alanina aminotransferase (ALT), aspartato aminotransferase (AST), gama-glutamil transferase (GGT), fosfatase alcalina (ALKP), bilirrubina total (TBIL), albumina (ALB), globulina (GLOB) e proteína total (TP). Assim, a concentração de cada enzima, em todas as amostras de soro previamente mantidas em freezer $-80^{\circ} \mathrm{C}$, foi determinada com auxílio do analisador bioquímico Vet Test 8008 (Blood chemistry analyzer).

\subsection{ANÁLISE HISTOPATOLÓGICA}

O fígado cirrótico de todos os animais tratados ou não com os FHs foi submetido à análise histopatológica em microscopia de luz quanto às alterações celulares e teciduais, com auxílio de diferentes técnicas de colorações específicas para cada avaliação. As análises das lâminas foram realizadas sem que a identificação de cada amostra fosse conhecida, garantindo a imparcialidade dos resultados.

\subsubsection{Avaliação das alterações celulares}

Lâminas histológicas do tecido hepático dos animais cirróticos tratados $\left(\mathrm{FH} \mathrm{e} \mathrm{FH}^{+60 \mathrm{~d}}\right)$ ou não (CTs) com os FHs coradas em HE, azul da Prússia, ácido periódico de Schiff (PAS) e alcian blue foram analisadas em microscópio óptico, aumento de 600x quanto à presença de alterações celulares (Figura 15). Nas lâminas coradas em HE foram avaliadas a presença de 
células ovais, de inclusões eosinofílicas, figuras mitóticas, células binucleadas, esteatose, megalocitose, vacuolização, lesão nuclear e a presença de corpúsculo apoptótico. Foram avaliadas ainda, a presença de hemossiderina, em lâminas submetidas à coloração de azul da Prússia (cora deposição de ferro); o acúmulo de mucopolissacarídeos ácidos, pela coloração de alcian blue e de glicogênio, pela coloração em ácido periódico de Schiff (PAS).

Estas alterações foram avaliadas semi quantitativamente através da determinação de escores de 0 a 3 . Assim, o escore 0 correspondia a ausência da alteração, 1 = pouca, $2=$ moderada e 3 = intensa. Em seguida foram determinadas as frequências de cada intensidade de alteração.
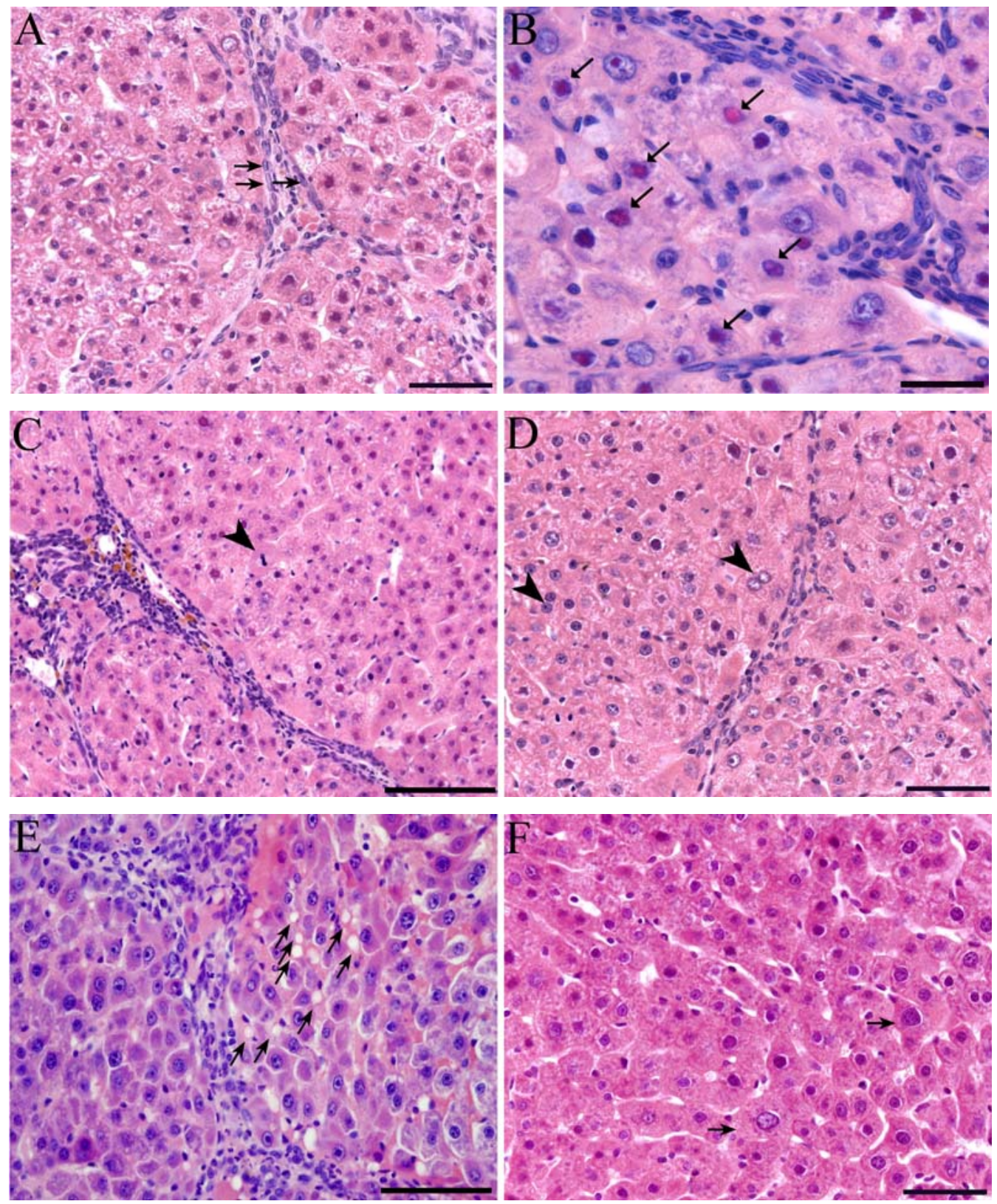

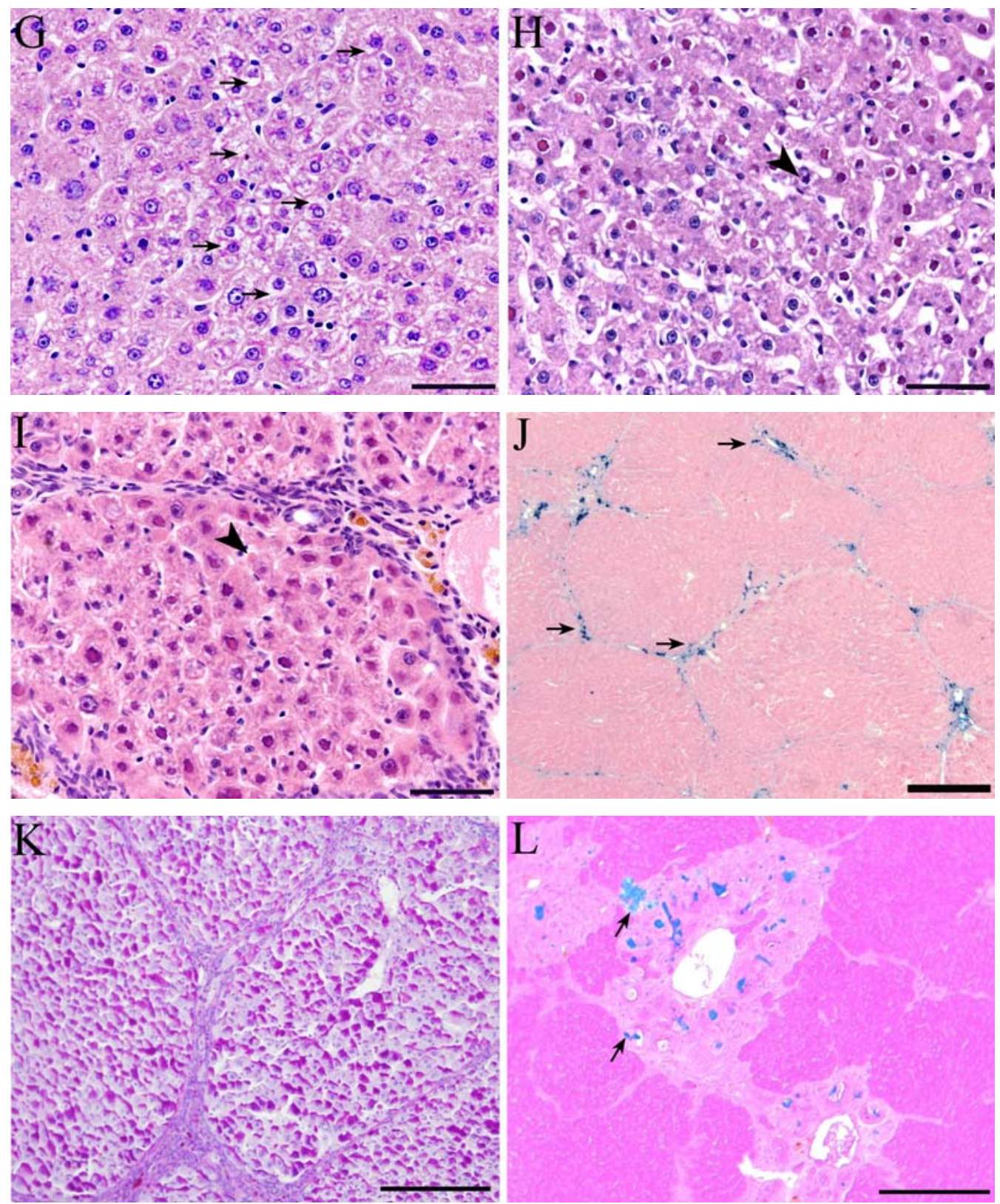

Figura 15 - Alterações celulares (setas) observadas no tecido hepático dos animais submetidos à indução da cirrose pela TAA e tratados $\left(\mathrm{FH}\right.$ ou $\mathrm{FH}^{+60 d}$ ) ou não $(\mathrm{CTs})$ com os $\mathrm{FHs}$. Coloração em HE: A) Células ovais, barra $=50 \mu \mathrm{m}$; B) Inclusões eosinofílicas, barra $=30 \mu \mathrm{m}$; C) Figuras de mitose, barra $=100 \mu \mathrm{m}$; D) Células binucleadas, barra $=50 \mu \mathrm{m}$; E) Esteatose, barra $=100 \mu \mathrm{m}$; F) Megalocitose; G) Vacuolização; H) Lesão nuclear; I) Corpúsculo apoptótico, barra= 50 $\mu \mathrm{m}$. Coloração de azul da Prússia, J) Hemossiderina, barra $=300 \mu \mathrm{m}$. Coloração de alcian blue, K) Deposição de mucopolissacarídeos, barra $=200 \mu \mathrm{m}$. Coloração de PAS, L) Deposição de glicogênio, barra= $200 \mu \mathrm{m}$ 


\subsubsection{Avaliação das alterações teciduais}

Através da análise das alterações teciduais observadas no fígado dos animais tratados ( $\mathrm{FH}$ e $\mathrm{FH}^{+60 \mathrm{~d}}$ ) ou não (CTs) com os $\mathrm{FHs}$ foram determinados o estadiamento da cirrose, o índice de atividade histológica e a proliferação dos ductos.

4.8.2.1 Determinação do estadiamento da cirrose hepática e índice de atividade histológica

A determinação do estadiamento da cirrose hepática e o cálculo do índice de atividade histológica (IAH) foram realizados de acordo com os critérios clássicos estabelecidos por Knodell et al. (1981) e modificados por Ishak et al. (1995), onde as lesões foram classificadas segundo o IAH (escores entre 1 e 18) e estadiamento da fibrose (escores entre 1 e 6) (Quadros 3 e 4). Para a realização da análise do IAH foram utilizadas lâminas coradas em HE analisadas nos aumentos de 40, 100 e 400x (microscópio Olympus PX21, Tokyo, Japan). A análise para a determinação do estadiamento da fibrose foi realizada em aumento de 40x, em lâminas coradas por picrossírius, que apresenta afinidade específica pelas fibras colágenas. 


\begin{tabular}{|c|c|}
\hline Necrose de Piecemeal (hepatite de interface) & Score \\
\hline Ausente & 0 \\
\hline Suave (focal / poucas regiões portais) & 1 \\
\hline Suave a Moderado (focal / diversas regiões portais) & 2 \\
\hline Moderado (contínuo ao redor de $<50 \%$ das regiões portais ou sinusoidais) & 3 \\
\hline Severo (contínuo ao redor de $>50 \%$ das regiões portais ou sinusoidais) & 4 \\
\hline Necrose & Score \\
\hline Ausente & 0 \\
\hline Necrose focal & 1 \\
\hline Necrose em Zona 3 (poucas regiões) & 2 \\
\hline Necrose em Zona 3 (diversas regiões) & 3 \\
\hline Necrose em Zona 3 e ocasionalmente na ponte v. porta - v. terminal hepática & 4 \\
\hline Necrose em Zona 3 e múltiplos locais na ponte v. porta - v. terminal hepática & 5 \\
\hline Necrose multiacinar & 6 \\
\hline Necrose lítica focal / apoptose / inflamação focal* & Score \\
\hline Ausente & 0 \\
\hline 1 foco ou menos por campo (objetiva de 10x) & 1 \\
\hline 2 a 4 focos por campo (objetiva de $10 x$ ) & 2 \\
\hline 5 a 10 focos por campo (objetiva de $10 x$ ) & 3 \\
\hline Mais de 10 focos por campo (objetiva de $10 x$ ) & 4 \\
\hline Inflamação portal & Score \\
\hline Ausente & 0 \\
\hline Suave (poucas regiões portais) & 1 \\
\hline Moderado (diversas regiões portais) & 2 \\
\hline Acentuado (todas as regiões portais) & 3 \\
\hline Severo (todas as regiões portais) & 4 \\
\hline
\end{tabular}

Fonte: (modificado de ISHAK et al., 1995)

Quadro 3 - Índice de atividade histológica (IAH) e seus scores relacionados à graduação da hepatite crônica (ISHAK et al., 1995). *Não inclui infiltrado sinusoidal difuso por células inflamatórias 


\begin{tabular}{|c|c|}
\hline Alterações estruturais / Fibrose / Cirrose & Score \\
\hline Sem fibrose & 0 \\
\hline $\begin{array}{c}\text { Expansão da fibrose em algumas regiões portais, com ou sem pequenos septos } \\
\text { fibrosos }\end{array}$ & 1 \\
\hline $\begin{array}{c}\text { Expansão da fibrose em diversas regiões portais, com ou sem pequenos septos } \\
\text { pontes entre os espaços portais }\end{array}$ & 2 \\
\hline $\begin{array}{c}\text { Expansão da fibrose em diversas regiões portais, com ocasional formação de } \\
\text { expansão da fibrose nas regiões portais, com marcante formação de pontes } \\
\text { entre os espaços portais e entre a v. porta e v. terminal hepática }\end{array}$ & 3 \\
\hline $\begin{array}{c}\text { Marcante formação de pontes entre os espaços portais e entre a v. porta e v. } \\
\text { terminal hepática, com formação ocasional de nódulos (cirrose incompleta) }\end{array}$ & 5 \\
\hline Cirrose & 6 \\
\hline
\end{tabular}

Fonte: (modificado de ISHAK et al., 1995)

Quadro 4 - Parâmetros histopatológicos e seus scores para o estadiamento da fibrose nas hepatites crônicas (ISHAK et al., 1995)

\subsubsection{Avaliação da proliferação dos ductos}

A proliferação de ductos foi avaliada pela atribuição de escores, semelhante à metodologia utilizada na avaliação das alterações celulares.

\subsubsection{Análise morfométrica do colágeno}

Para avaliar os efeitos do tratamento sobre a fibrogênese hepática, os fígados cirróticos de todos os animais tratados $\left(\mathrm{FH}\right.$ e $\mathrm{FH}^{+60 \mathrm{~d}}$ ) ou não (CTs) com os $\mathrm{FHs}$ foram submetidos à quantificação dos colágenos interlobular e intralobular. A análise foi realizada 
em lâminas coradas com picrossírius, e observadas em microscópio óptico. A quantificação das fibras colágenas interlobulares foi realizada com auxílio de sistema de análise de imagens computadorizado (AxioVision 4.8 Zeiss, Carl Zeiss), em aumento de 200x e as intralobulares em 600x. Os valores foram expressos em porcentagem de cada localização de colágeno em relação à área total analisada.

\subsubsection{Imunofluorescência para os colágenos tipo 1 e 3}

Os colágenos 1 e 3 são os tipos mais prevalentes na cirrose hepática. Desta forma, o efeito do tratamento com os FHs sobre a deposição destes dois tipos de colágenos foi avaliado pela técnica de imunofluorescência, no tecido hepático obtido no momento da eutanásia dos animais. Lâminas silanizadas em branco, obtidas dos fígados ( $\mathrm{n}=4$ /grupo/anticorpo) cirróticos tratados $\left(\mathrm{FH}\right.$ e $\left.\mathrm{FH}^{+60 \mathrm{~d}}\right)$ ou não $(\mathrm{CTs})$ com os $\mathrm{FHs}$, foram desparafinizadas e hidratadas. Em seguida foram lavadas e submetidas ao método de desmascaramento para exposição e recuperação dos sítios antigênicos, através da digestão enzimática com pepsina suína (SigmaAldrich $^{\circledR}$ ), $2 \mathrm{mg} / 500 \mu \mathrm{L}$ de ácido acético 0,5 N (Labsynth Produtos para Laboratório Ltda), permanecendo em câmara úmida, a $37^{\circ} \mathrm{C}$, por 20 minutos. Transcorrido este período, as lâminas foram lavadas e incubadas em câmara úmida, durante a noite, a $4^{\circ} \mathrm{C}$ para o bloqueio de sítios inespecíficos juntamente com a incubação com o anticorpo primário anti-colágeno tipo I (1:50, Rockland Immunochemicals, Pennsylvania, U.S.A.) e anti-colágeno tipo III (1:100, Rockland Immunochemicals, Pennsylvania, U.S.A.) diluídos em PBS+1\%BSA (albumina sérica bovina) $+0,1 \% \mathrm{NaN}_{3}$ (trinitreto de sódio). Posteriormente, as lâminas foram lavadas e incubadas com o anticorpo secundário policlonal anti-coelho (1:50, no mesmo diluente do primário) conjugado com o fluoróforo FITC (Dako Cytomation, Denmark), em câmara úmida, por 90 minutos, ao abrigo da luz. As lâminas foram lavadas e na última lavagem foi acrescido $40 \mu \mathrm{L}$ de iodeto de propídeo, para possibilitar a visualização nuclear. Foram novamente lavadas para a remoção do excesso de iodeto e montadas em meio Prolong Gold (Invitrogen, Eugene, Oregon, U.S.A.), para evitar o esgotamento da fluorescência. Os tecidos corados foram fotografados apenas para representar a participação de cada tipo de colágeno na cirrose hepática. 


\subsubsection{Imunofluorescência para $\alpha$-SMA}

Após injúria hepática ocorre a ativação das células estreladas, que é a principal célula envolvida no processo fibrogênico, responsável pelo recrutamento de células inflamatórias e deposição de colágeno. Esta ativação, dentre outras características, é marcada pela expressão da proteína $\alpha$-actina de músculo liso ( $\alpha$-SMA). Assim, a identificação da presença de $\alpha$-SMA é um indicativo da ativação das células estreladas e/ou do aumento da deposição de colágeno. Desta forma, para avaliar o efeito do tratamento com os FHs, sobre a ativação das células estreladas, a presença da $\alpha$-SMA foi identificada pela técnica de imunofluorescência. Lâminas silanizadas em branco, obtidas dos fígados (n=10/grupo) cirróticos tratados $\left(\mathrm{FH} \mathrm{e} \mathrm{FH}^{+60 \mathrm{~d}}\right.$ ) ou não (CTs) com os FHs, foram desparafinizadas, hidratadas, lavadas e submetidas ao desmascaramento em tampão Tris-EDTA (pH 9,0), por 20 minutos, em microondas. Em seguida, foram lavadas e submetidas ao bloqueio da peroxidase endógena em solução de peróxido de hidrogênio $10 \%\left(\mathrm{H}_{2} \mathrm{O}_{2}\right.$ em água destilada), por 30 minutos, ao abrigo da luz. Após lavagens, foi realizado o bloqueio das reações inespecíficas com TNB (pH 7,5) (Blocking Reagent, PerkinElmer Life Sciences, Massachusetts, U.S.A.) em câmara úmida, por 20 minutos, à temperatura ambiente. As lâminas foram lavadas e incubadas em câmara úmida, durante a noite, a $4^{\circ} \mathrm{C}$ com o anticorpo primário monoclonal anti- $\alpha$-SMA (1:500 em TNB, Sigma-Aldrich, Missouri, U.S.A.). Posteriormente, as lâminas foram incubadas com o anticorpo secundário policlonal biotinilado (1:500 em TNB, Dako Denmark A/S, Denmark), em câmara úmida, por 30 minutos, a temperatura ambiente. Depois de lavadas, as lâminas foram incubadas com o complexo estreptavidina-peroxidase (1:100 em TNB, PerkinElmer Life Sciences, Massachusetts, U.S.A.) em câmara úmida, por 30 minutos, a temperatura ambiente. A reação foi amplificada pelo sistema TSA conjugado com fluoresceína (1:100, Fluorescein Tyramide Reagent, PerkinElmer Life Sciences, Massachusetts, U.S.A.). Finalmente as lâminas foram incubadas com iodeto de propídeo (1:1000 em PBS), lavadas e montadas em meio Prolong Gold (Invitrogen, Eugene, Oregon, U.S.A.), para evitar o esgotamento da fluorescência e vedadas com esmalte.

A quantificação da $\alpha$-SMA foi realizada em microscópio de fluorescência (Nikon Eclipse E800, Media Cybernetics, Inc.) no aumento de 400x, pela contagem de todas as células estreladas $\alpha$-SMA positivas. Foi determinada a área de cada corte analisado com o auxílio de sistema de análise de imagens computadorizado (Image Pro ${ }^{\circledR}$-Plus, 4.5, Media 
Cybernetics, Inc.) e os resultados foram expressos em número de células estreladas $\alpha$-SMA ${ }^{+}$, por $\mathrm{mm}^{2}$ de tecido hepático.

\subsubsection{Imuno-histoquímica para PCNA}

O PCNA (Proliferating Cell Nuclear Antigen) é uma proteína auxiliar da DNA polimerase e está envolvido na replicação do DNA. A imunomarcação das células PCNA $^{+}$ tem sido usada para a avaliação da proliferação celular (XUE et al., 2003). Assim, para analisar os possíveis efeitos do tratamento com os FHs sobre a proliferação celular nos fígados cirróticos, foi utilizada a técnica de imuno-histoquímica para a identificação dos hepatócitos $\mathrm{PCNA}^{+}$. Lâminas silanizadas em branco, obtidas dos fígados (n=10/grupo) cirróticos tratados $\left(\mathrm{FH}\right.$ e $\mathrm{FH}^{+60 \mathrm{~d}}$ ) ou não (CTs) com os $\mathrm{FHs,} \mathrm{foram} \mathrm{desparafinizadas,}$ rehidratadas e submetidas ao bloqueio da peroxidase endógena por 5 minutos $\left(\mathrm{H}_{2} \mathrm{O}_{2}\right.$ a $3 \%$ em metanol). Em seguida foram lavadas com tampão TRIS (pH 7,4) e desmascaradas em tampão citrato (pH 6,0), no microondas, por 15 minutos. Após lavagem foi realizado o bloqueio das reações inespecíficas com TNB (pH 7,5) (Blocking Reagent, PerkinElmer Life Sciences, Massachusetts, U.S.A.) em câmara úmida, a $37^{\circ} \mathrm{C}$, por 30 minutos. Posteriormente foram lavadas e incubadas com o anticorpo primário monoclonal anti-PCNA (1:100 em TRIS, AntiProliferating Cell Nuclear Antigen, Zymed, San Francisco, U.S.A.), em câmara úmida, durante a noite, $a 4^{\circ} \mathrm{C}$. As lâminas foram lavadas e submetidas ao sistema de amplificação por polímeros não biotinilados. Inicialmente foram incubadas com o polímero Post Primary Block (Novocastra ${ }^{T M}$, New Castle Upon Tyne, United Kingdom), em câmara úmida, por 30 minutos, a temperatura ambiente; lavadas e incubadas nas mesmas condições, com o reagente Polymer $\left(\right.$ NovoLink $^{\circledR}$, Novocastra ${ }^{T M}$, New Castle Upon Tyne, United Kingdom). As células PCNA ${ }^{+}$ foram reveladas utilizando o Kit DAB (3'3- Diaminobenzidine Tetrahydrochloride) na diluição de 1:1000 (DAB Chromogen +Substrate Buffer, Dako North Ameria, Califórnia, U.S.A.) e contracoradas com hematoxilina, desidratadas e montadas em meio permount (Fisher Scientific, New Jersy, U.S.A.). A proliferação celular foi avaliada pela contagem de 1.000 núcleos de hepatócitos, obtidos aleatoriamente em aumento de 200x e posterior cálculo da porcentagem média de células PCNA positivas. 


\subsection{AVALIAÇÃO DA EXPRESSÃO GÊNICA POR PCR EM TEMPO REAL}

A técnica de PCR em tempo real foi utilizada para identificar se o tratamento com os FHs afetou a expressão dos genes relacionados à fibrogênese hepática. A fibrogênese é caracterizada por um desequilíbrio entre a deposição e degradação dos componentes da matriz extracelular. Assim, foi avaliada a expressão dos genes relacionados às principais proteínas envolvidas neste processo, como o TGF $\beta$-1, importante ativador das células estreladas, sendo indiretamente responsável pela deposição do colágeno; colágeno tipo 1 (colágeno $1 \alpha 1$ ), o principal tipo de colágeno depositado na fibrose hepática; as metaloproteinases MMP-2 e MMP-13, responsáveis pela degradação do colágeno e de outros componentes da matriz extracelular; a TIMP-1, principal inibidora das metaloproteinases, e o PLAU, responsável pela conversão de plasminogênio em plasmina, a qual tem ação proteolítica sobre os componentes da matriz extracelular e tem efeito ativador sobre as MMPs.

\subsubsection{Extração do RNA}

A extração do RNA foi realizada com o kit para extração de RNA - RNAspin Mini RNA Isolation Kit (GE Healthcare, UK). Aproximadamente $30 \mathrm{mg}$ de tecido hepático (n=6 amostras/grupo), mantido a $-80^{\circ} \mathrm{C}$, foi adicionado a $350 \mu \mathrm{L}$ do tampão de lise RA1 acrescido de 3,5 $\mu \mathrm{L}$ de $\beta$-mercaptoetanol (Sigma Aldrich, U.S.A.), sofrendo maceração com pistilo autoclavado e RNAse-free. A partir deste momento a mistura foi transferida para uma coluna de extração, seguindo o protocolo determinado pelo fabricante do kit. O processo consistiu basicamente em colocar as amostras maceradas em pequenas colunas de extração (adaptáveis a um eppendorff de 1,5 mL), responsáveis pela retenção do RNA, enquanto o mesmo foi lavado e purificado com uma seqüência de reagentes. Na etapa final, o RNA foi liberado da coluna pela adição de água RNase-free, sendo mantido em freezer $-80^{\circ} \mathrm{C}$ até o momento do uso. 


\subsubsection{Determinação da integridade e quantificação do RNA total}

Uma alíquota de $7 \mu \mathrm{L}$ foi retirada para quantificação e verificação da integridade do RNA. O restante foi armazenado imediatamente em freezer $-80^{\circ} \mathrm{C}$ até sua utilização. A análise qualitativa foi realizada submetendo-se $5 \mu \mathrm{L}$ da amostra do RNA extraído acrescida de $2 \mu \mathrm{L}$ do corante Blue Green Loading Dye I (LGC Biotecnologia) a eletroforese em gel de agarose 1,5\% diluída em TAE $1 \mathrm{X}(48,4 \mathrm{~g}$ de Tris base; $20 \mathrm{~mL}$ de EDTA 0,5 M, pH 8,0; 11,4 mL de ácido acético; água deionizada autoclavada q.s.p. $1000 \mathrm{~mL}), 60 \mathrm{~V}$, por 1,5 hora. Após a eletroforese, o gel foi submetido à luz ultravioleta para a visualização das bandas $28 \mathrm{~S}$ e $18 \mathrm{~S}$ no aparelho ImageQuant 400 (GE Healthcare, USA). A correta identificação destas bandas indica a qualidade do RNA.

$\mathrm{O}$ restante da amostra $(2 \mu \mathrm{L})$ foi diluída em $58 \mu \mathrm{L}$ de $\mathrm{H}_{2} \mathrm{O}$ RNase-free para quantificação da concentração de RNA total em biofotômetro (Eppendorf, Hamburg, Germany) a 260/280nm. Amostras com absorbância entre 1,7 até 2,0 ng/ $\mu \mathrm{L}$ indicaram baixa contaminação do RNA, sendo consideradas de boa qualidade para a transcrição reversa.

\subsubsection{Transcrição reversa - obtenção do DNA complementar (cDNA)}

Uma alíquota de cada amostra de RNA total foi retirada e a concentração ajustada para $1000 \mathrm{ng} / \mu \mathrm{L}$. Para eliminar quaisquer resquícios de DNA, o RNA total diluído foi tratado com DNAse I. Foi utilizado $1 \mu \mathrm{L}$ de DNAse I para tratar $4 \mu \mathrm{g} / \mu \mathrm{L}$ de RNA total. Os eppendorfs foram mantidos a temperatura ambiente por 15 minutos, sendo adicionado $1 \mu \mathrm{L}$ de EDTA (25 $\mathrm{mM}$ ) para bloquear a ação da enzima e aquecidos por 10 minutos, a $65^{\circ} \mathrm{C}$, em banho seco, seguido de resfriamento em banho de gelo. As amostras receberam $1 \mu \mathrm{L}$ de Oligo DT; $1 \mu \mathrm{L}$ de dNTPs (mix $10 \mathrm{mM}-2,5 \mathrm{mM}$ de cada dNTP) e posteriormente foram incubadas a $65^{\circ} \mathrm{C}$, por 5 minutos e resfriadas em gelo. Ainda no gelo, foram adicionados a cada tubo $4 \mu \mathrm{L}$ do buffer 5X (superscript II); $2 \mu \mathrm{L}$ de DTT $1 \mathrm{M} ; 1 \mu \mathrm{L}$ de RNAse OUT, seguindo a incubação por 2 
minutos a $42^{\circ} \mathrm{C}$ e resfriamento no gelo. Foi acrescido $1 \mu \mathrm{L}$ da enzima de transcrição reversa superscript II, permanecendo sob incubação a $42^{\circ} \mathrm{C}$, por 50 minutos e em seguida por $70^{\circ} \mathrm{C}$ por 15 minutos e resfriada no gelo. Posteriormente foi acrescido $1 \mu \mathrm{L}$ da enzima RNAse $\mathrm{H}$ (para eliminação de resíduos de RNA da amostra de cDNA), permanecendo por 20 minutos a $37^{\circ} \mathrm{C}$ e resfriada no gelo. $\mathrm{O}$ cDNA foi armazenado a $-20^{\circ} \mathrm{C}$ até o momento da sua amplificação. Todos os reagentes foram fornecidos pela Invitrogen Life Technologies.

\subsubsection{Assays (primers) e probes}

Todos os reagentes foram fornecidos pela Applied Biosystems (Applied Biosystems, Foster City, CA), os TaqMan probes foram marcados com um corante fluorescente reporter, FAM (6-carboxifluoresceína), na posição 5' final e um corante fluorescente quencher TAMRA (6-carboxi-tetrametil-rodamina) na posição 3' final. O quadro 5 relaciona todos os assays/primers utilizados.

\begin{tabular}{|c|c|}
\hline Genes & Assay (ID) \\
\hline Beta-actina & 4331348 \\
\hline Colágeno1 $\alpha 1$ & Rn 00801649_g1 \\
\hline TGF $\beta-1$ & Rn 00572010_m1 \\
\hline MMP-II & Rn 01538167_m1 \\
\hline TIMP-1 & Rn 00587558_m1 \\
\hline MMP-13 & Rn 01448191_g1 \\
\hline PLAU & Rn 00695755_m1 \\
\hline
\end{tabular}

Quadro 5 - Assays (primers) da empresa Applied Biosystems utilizados para análise da expressão gênica por PCR em tempo real: Colágeno1 $\alpha 1$, colágeno tipo 1 alfa 1; TGF $\beta-1$, fator de crescimento transformador beta 1; MMP-2, metaloproteinase 2; MMP-13, metaloproteinase 13; TIMP-1, inibidor tecidual da metaloproteinase 1 e PLAU, ativador de plasminogênio tipo uroquinase 


\subsubsection{Método de pré-amplificação gênica}

O gene da MMP-13 apresentou uma baixa amplificação impossibilitando a sua análise, desta forma, foi necessário uma pré-amplificação das amostras de cDNA (n=6/grupo) junto ao gene MMP-13 para possibilitar a detecção da expressão gênica pela técnica de PCR em tempo real. O controle endógeno $\beta$-actina sofreu o mesmo processo de pré-amplificação para possibilitar a comparação com a expressão da MMP-13.

Previamente foi realizado um pooled com os genes MMP-13 e $\beta$-actina diluído em TE 1x $(1: 98 \mu \mathrm{L})$; a seguir, em $12,5 \mu \mathrm{L}$ de cDNA puro foi adicionado $12,5 \mu \mathrm{L}$ do pooled inicialmente preparado, sendo posteriormente misturados a $25 \mu \mathrm{L}$ do reagente de amplificação PreAmp Master Mix (TaqMan ${ }^{\circledR}$ PreAmp Master Mix Kit, Applied Biosystems, California, USA) e incubadas em termociclador para as reações de ativação enzimática $\left(10 \mathrm{~min}\right.$, a $\left.95^{\circ} \mathrm{C}\right)$, desnaturação $\left(15 \mathrm{seg}\right.$, a $\left.95^{\circ} \mathrm{C}\right)$ e anelamento/extensão $\left(4 \mathrm{~min}\right.$, a $\left.60^{\circ} \mathrm{C}\right)$. Após a amplificação as amostras foram submetidas à quantificação da expressão gênica por PCR em tempo real.

\subsubsection{Quantificação da expressão gênica por PCR em tempo real}

A análise por PCR em tempo real foi realizada em sistema de detecção ABI PrismÒ 7000 (Applied Biosystems, Foster City, CA) o qual contém uma câmara CCD acoplada que captura a fluorescência emitida e analisa os dados utilizando um programa de detecção Sequence Detector versão 1.6. Para avaliação da expressão, foram colocados em tubos apropriados (Opitcal Tubes Applied Biosystems) $5 \mu 1$ de cada produto de PCR (cerca de $10 \mathrm{ng}$ de RNA total), tampão A TaqMan $1 \mathrm{X}, \mathrm{MgCl}_{2}$ 5,5 mM, $200 \mu \mathrm{M}$ de dATP/dCTP/dGTP, 400 $\mu \mathrm{M}$ dUTP, $200 \mathrm{nM}$ dos primers (senso e antisenso), $100 \mathrm{nM}$ das probes TaqMan, 0,01 U/mL de AmpErase e 0,025 U/ $\mu \mathrm{L}$ da DNA polimerase AmpliTaq Gold em um volume total de 50 $\mu \mathrm{L}$. Após a completa mistura dos reagentes, cada tubo foi fechado com tampas MicroAmp Optical (Applied Biosystems). Todas as reações foram corridas em duplicata. As condições de 
amplificação utilizadas foram: 2 minutos a $50^{\circ} \mathrm{C}, 10$ minutos a $95^{\circ} \mathrm{C}$; seguidos de 50 ciclos a $90^{\circ} \mathrm{C}$ por 15 segundos para desnaturação da fita de cDNA e a $60^{\circ} \mathrm{C}$ por 1 minuto para sua extensão. A interpretação dos resultados foi realizada conforme descrito pelo método comparativo de Livak e Schmittgen (2001) onde a expressão relativa dos genes corresponde a $2^{-\Delta \Delta \mathrm{Ct}}$.

\subsection{ANÁLISE ESTATÍSTICA}

Os grupos tratados com os $\mathrm{FHs}\left(\mathrm{FH}\right.$ e $\mathrm{FH}^{+60 \mathrm{~d}}$ ) foram comparados com os seus respectivos controles (CTs) e com as biópsias (análises bioquímicas e histopatológica) obtidas dos animais do próprio grupo, gerando comparações intra e inter grupos. Antes da realização dos testes estatísticos foi aplicado o teste de normalidade Anderson-Darling com intuito de verificar a homocedasticidade (paramétrico e não paramétrico) dos dados. Para as comparações entre dois grupos de dados não pareados considerados paramétricos foi utilizado o teste $t$-Student e para os não paramétricos, foi realizado o teste de Mann-Whitney. O teste de Wilcoxon foi utilizado nas análises de dados pareados não paramétricos. As análises foram realizadas com auxílio dos softwares Minitab ${ }^{\circledR}$ Release 14 Statistical Software (State College, PA - USA) e GraphPad InStat 3.06 (GraphPad Software Inc, San Diego, USA). Foram consideradas estatisticamente significantes as diferenças onde $p<0,05$. 


\section{RESULTADOS}

Os resultados obtidos com os animais submetidos à indução da cirrose pela administração de TAA $\left(\mathrm{FH}, \mathrm{FH}^{+60 \mathrm{~d}}\right.$ e seus respectivos $\left.\mathrm{CTs}\right)$ e tratados $\left(\mathrm{FH}^{\mathrm{a}} \mathrm{FH}^{+60 \mathrm{~d}}\right)$ ou não (CTs) com os FHs serão apresentados separadamente de acordo com os períodos de análise pós-tratamento. Desta forma, serão apresentados todos os resultados obtidos imediatamente após o tratamento e subsequentemente, os dados obtidos 60 dias pós-tratamento. Ainda, serão repetidas algumas partes da metodologia, com a finalidade de auxiliar na exposição e interpretação dos dados. Apenas a avaliação dos sinais clínicos não será apresentada separadamente.

\subsection{OS SINAIS CLÍNICOS DECORRENTES DA ADMINISTRAÇÃO DA TAA E/OU DO TRATAMENTO COM OS FHS NÃO FORAM OBSERVADOS EM TODOS OS ANIMAIS E DESAPARECERAM PÓS-ADMINISTRAÇÃO}

Os sinais clínicos observados foram diferentes durante e após a administração da TAA. Durante as 14 semanas de indução pela aplicação da TAA os animais apresentaram flacidez da pele, posição álgica e diarréia. No período após a indução foram observados alopecia, secreção porfirinêmica (avermelhada ao redor dos olhos) da glândula de Harder, piloereção e amarelamento da pelagem. Os grupos $\left(\mathrm{FH}, \mathrm{FH}^{+60 \mathrm{~d}}\right)$ submetidos ao tratamento com os FHs mostraram posição álgica e piloereção. A manifestação destes sintomas não foi observada em todos os animais, e aparentemente estava diretamente relacionada aos tratamentos (TAA e FHs), desaparecendo logo após o término da indução e/ou do tratamento. 


\subsection{RESULTADOS DOS ANIMAIS CIRRÓTICOS TRATADOS (FH) OU NÃO (CT) COM OS FHS POR 12 DIAS E EUTANASIADOS IMEDIATAMENTE APÓS O TRATAMENTO}

Serão apresentados os resultados obtidos com as análises realizadas nos grupos $\mathrm{FH}$ e seu CT. Conforme já comentado, quando necessário os dados do grupo $\mathrm{FH}$ foram comparados com as biópsias, obtidas dos animais do próprio grupo, gerando uma comparação intragrupo.

\subsubsection{A administração da TAA e/ou o tratamento com os FHs não provocaram aumento na taxa de mortalidade dos animais}

O grupo FH apresentou 13,33\% de mortalidade, correspondente à morte de dois animais. Um dos animais morreu no final do período de indução da cirrose hepática, e o outro no momento da execução da biópsia. Não foi observado nenhum óbito no grupo CT.

\subsubsection{O tratamento com os FHs reduziu o peso médio dos animais submetidos à indução da cirrose com a TAA}

O gráfico 1 mostra a evolução do peso corporal médio dos animais submetidos ao modelo de indução pela TAA e tratados (FH) ou não (CT) com os FHs por 12 dias. Os grupos apresentaram um comportamento linear constante, sem grandes variações de peso, ao longo de toda a indução da cirrose pela TAA ( $1^{\mathrm{a}}$ a $14^{\mathrm{a}}$ semanas). A partir do final da indução, $14^{\mathrm{a}}$ semana, o peso dos animais do grupo $\mathrm{FH}$ apresentou uma redução estatisticamente 
significante em comparação ao grupo CT. Entretanto, nas duas últimas semanas, o peso dos dois grupos ficou igual até a eutanásia ( $18^{\mathrm{a}}$ semana).

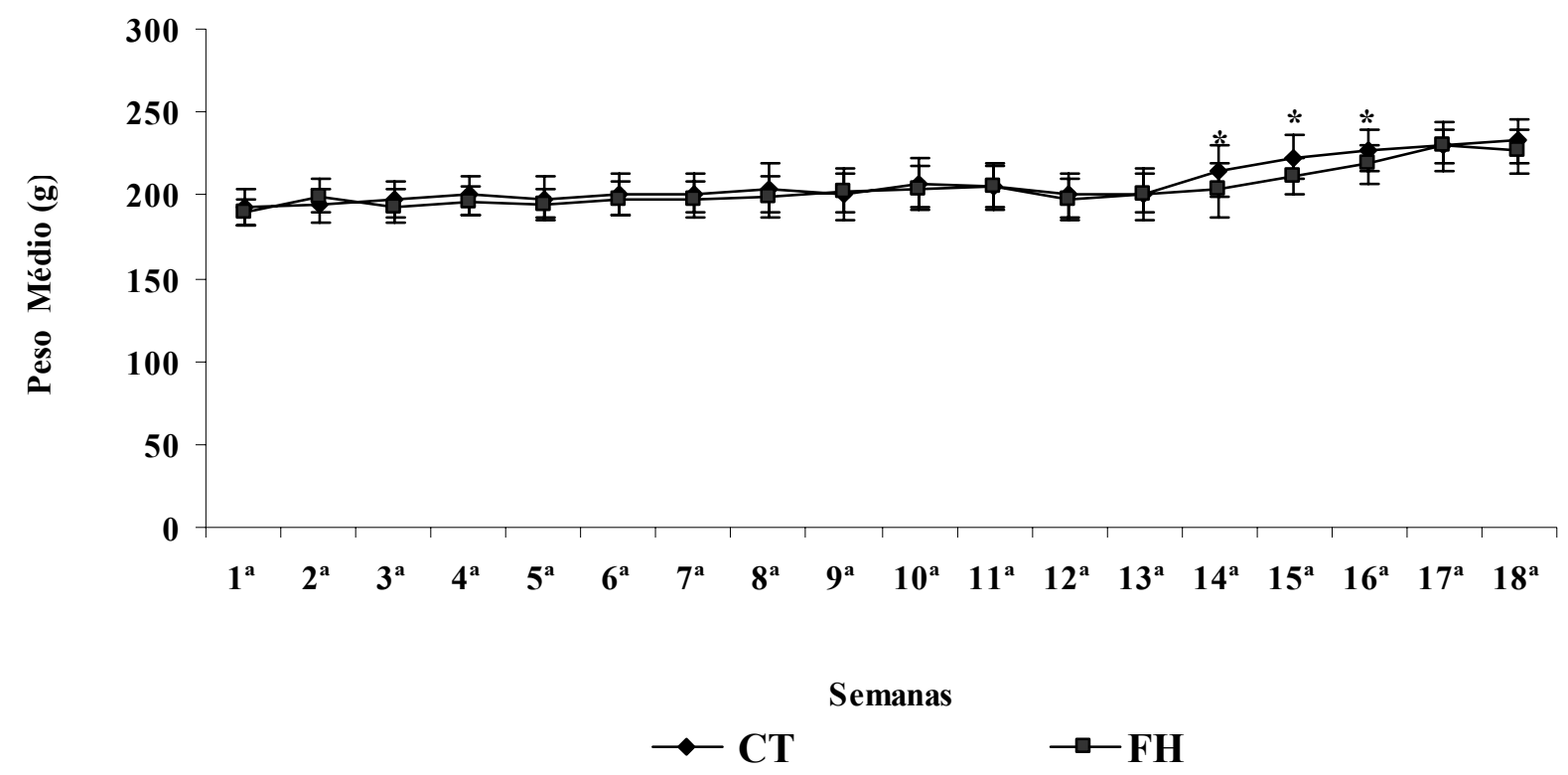

Gráfico 1 - Evolução semanal do peso médio dos animais submetidos à indução da cirrose pela TAA, tratados (FH) ou não (CT) com os fatores $\mathrm{FH}$ por 12 dias e eutanasiados pós-tratamento: * diferença estatística significante em relação ao $\mathrm{CT}, p<0,05$, teste $t$-Student

\subsubsection{O tratamento com os FHs aumentou a densidade do fígado}

Os animais do grupo FH apresentaram aumento no peso da carcaça, redução no índice vísceras/peso corporal (Tabela 1 e Gráfico 2) e aumento na densidade do fígado (Tabela 1 e Gráfico 3) em relação ao CT. Os demais parâmetros não apresentaram alterações significantes. 
Tabela 1 - Parâmetros biométricos médios obtidos após a eutanásia dos animais submetidos à indução da cirrose pela TAA, tratados (FH) ou não (CT) com os fatores FH por 12 dias e eutanasiados imediatamente após o tratamento

\begin{tabular}{|c|c|c|}
\hline Parâmetros & $\begin{array}{c}\text { CT } \\
(\mathrm{n}=30)\end{array}$ & $\begin{array}{c}\text { FH } \\
(\mathrm{n}=13)\end{array}$ \\
\hline Peso Corporal (g) & $222,60 \pm 13,03$ & $226,30 \pm 9,40$ \\
\hline Peso da Carcaça (g) & $168,80 \pm 11,64$ & $180,03 \pm 7,61 *$ \\
\hline Peso do Fígado (g) & $10,14 \pm 1,43$ & $10,16 \pm 0,60$ \\
\hline Peso das Vísceras (g) & $47,20 \pm 5,00$ & $44,00 \pm 3,35$ \\
\hline Índice Vísceras/Peso Corporal (\%) & $21,22 \pm 2,09$ & $19,44 \pm 1,30 *$ \\
\hline Índice Hepato/Corporal (\%) & $6,03 \pm 0,93$ & $5,65 \pm 0,34$ \\
\hline Índice Hepatossomático (\%) & $4,60 \pm 0,60$ & $4,50 \pm 0,23$ \\
\hline Volume do Fígado $\left(\mathrm{cm}^{3}\right)$ & $9,40 \pm 1,32$ & $9,20 \pm 0,60$ \\
\hline Densidade do Fígado $\left(\mathrm{cm}^{3} / \mathrm{g}\right)$ & $1,09 \pm 0,01$ & $1,11 \pm 0,03 *$ \\
\hline
\end{tabular}

* diferença estatística significante em relação ao CT, $p<0,05$, teste $t$-Student

Os gráficos 2 e 3 representam os resultados discriminados na tabela 1. 


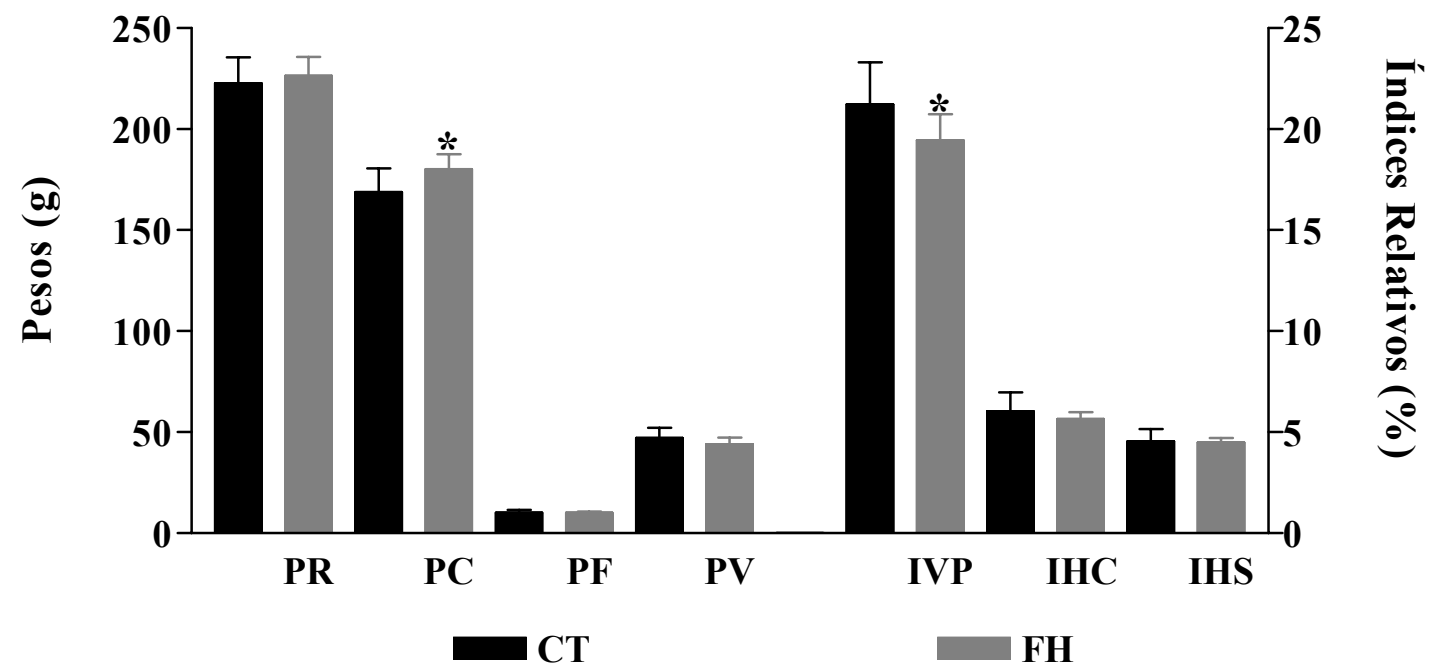

Gráfico 2 - Parâmetros biométricos obtidos após a eutanásia dos animais submetidos à indução da cirrose pela TAA, tratados $(\mathrm{FH})$ ou não $(\mathrm{CT})$ com os fatores $\mathrm{FH}$ por 12 dias e eutanasiados imediatamente após o tratamento: PR, peso do rato; PC, peso da carcaça; $\mathrm{PF}$, peso do fígado; PV, peso das vísceras; IVR, índice vísceras/peso corporal; IHC, índice hepatocorporal; IHS, índice hepatossomático; * diferença estatística significante em relação ao CT, $p<0,05$, teste $t$-Student

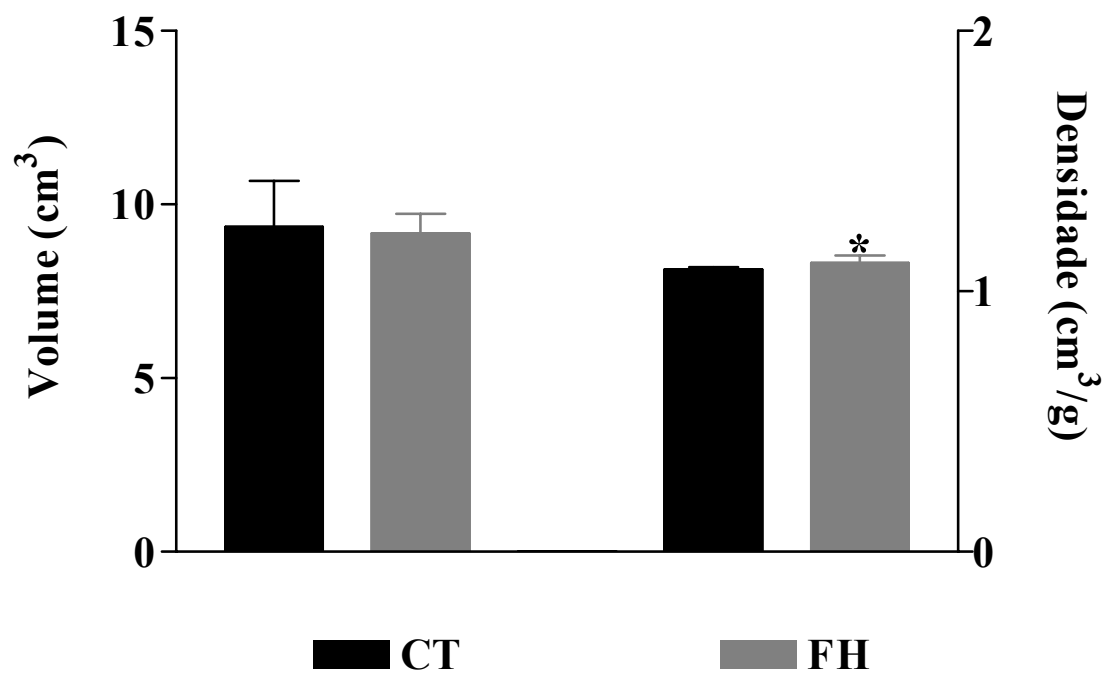

Gráfico 3 - Volume e densidade do fígado dos animais submetidos à indução da cirrose pela TAA, tratados (FH) ou não (CT) com os FHs por 12 dias e eutanasiados imediatamente após o tratamento: * diferença estatística significante em relação ao $\mathrm{CT}, p<0,05$, teste t-Student 


\subsubsection{O tratamento com os FHs melhorou as funções hepáticas}

Os dados da análise bioquímica realizada com o sangue obtido antes da indução $\left(\mathrm{CS}_{0}\right)$, após a indução e antes do tratamento $\left(\mathrm{CS}_{1} \mathrm{~B}\right)$ e na eutanásia $\left(\mathrm{CS}_{1} \mathrm{E}\right.$ e $\left.\mathrm{CS}_{2} \mathrm{E}\right)$ foram comparados inter e intragrupos, gerando três comparações.

$\mathrm{Na}$ primeira comparação $\left(\mathrm{CS}_{2} \mathrm{E}-\mathrm{FH}\right.$ vs. $\left.\mathrm{CS}_{1} \mathrm{E}-\mathrm{CT}\right)$ foram avaliados os efeitos do tratamento com os FHs imediatamente após o tratamento da cirrose pela TAA, ou seja, foi analisado os efeitos sobre o desenvolvimento da cirrose. Desta forma, os dados bioquímicos do sangue obtido na eutanásia dos grupos $\mathrm{CT}\left(\mathrm{CS}_{1} \mathrm{E}-\mathrm{CT}\right)$ e $\mathrm{FH}\left(\mathrm{CS}_{2} \mathrm{E}-\mathrm{FH}\right)$ foram comparados entre si. O tratamento com os FHs reduziu significantemente os índices de ALKP, ALT, AST, GGT e GLOB e aumentou os níveis de ALB, os demais parâmetros não sofreram alterações (Tabela 2).

$\mathrm{Na}$ segunda $\left(\mathrm{CS}_{1} \mathrm{~B}-\mathrm{FH}\right.$ vs. $\left.\mathrm{CS}_{2} \mathrm{E}-\mathrm{FH}\right)$, foi realizada uma comparação intragrupo, onde os dados obtidos com o sangue coletado após a indução e antes do tratamento com os FHs $\left(\mathrm{CS}_{1} \mathrm{~B}-\mathrm{FH}\right)$ foram confrontados com os dados obtidos na eutanásia $\left(\mathrm{CS}_{2} \mathrm{E}-\mathrm{FH}\right)$. Esta comparação avaliou os efeitos do tratamento sobre as alterações provocadas pela TAA. O tratamento com os FHs reduziu significantemente os níveis de ALKP, ALT, AST, GGT, TBIL e aumentou os níveis da ALB, TP e GLOB (Tabela 2).

$\mathrm{Na}$ terceira comparação $\left(\mathrm{CS}_{0}\right.$ vs. $\left.\mathrm{CS}_{1} \mathrm{E}-\mathrm{CT}\right)$ foram avaliadas as alterações bioquímicas sofridas com o desenvolvimento da cirrose após o término da indução com a TAA. Como esperado, os animais apresentaram aumento estatisticamente significante em quase todos os parâmetros analisados, exceto nos níveis de ALB (Tabela 2). 
Tabela 2 - Parâmetros da função bioquímica hepática do sangue coletado na biópsia e na eutanásia dos animais induzidos à cirrose pela administração da TAA e tratados (FH) ou não (CT) com os FHs por 12 dias e eutanasiados imediatamente após o tratamento

\begin{tabular}{ccccc}
\hline Parâmetros & CS $_{\mathbf{0}}$ & $\mathbf{C S}_{1} \mathbf{B}-\mathbf{F H}$ & $\mathbf{C S}_{\mathbf{1}} \mathbf{E}-\mathbf{C T}$ & $\mathbf{C S}_{2} \mathbf{E}-\mathbf{F H}$ \\
& $(\mathrm{n}=10)$ & $(\mathrm{n}=13)$ & $(\mathrm{n}=10)$ & $(\mathrm{n}=13)$ \\
\hline ALB (g/dL) & $1,77 \pm 0,28$ & $1,93 \pm 0,32$ & $2,00 \pm 0,26$ & $2,28 \pm 0,27^{\mathbf{a b}}$ \\
ALKP (U/L) & $130,40 \pm 12,51$ & $250,08 \pm 21,85$ & $169,90 \pm 17,75^{\mathbf{c}}$ & $150,15 \pm 21,14^{\mathbf{a b}}$ \\
ALT (U/L) & $49,30 \pm 4,57$ & $101,31 \pm 11,40$ & $73,30 \pm 5,72^{\mathbf{c}}$ & $63,31 \pm 7,12^{\mathbf{a b}}$ \\
AST (U/L) & $93,80 \pm 10,39$ & $245,31 \pm 10,42$ & $108,30 \pm 3,30^{\mathbf{c}}$ & $92,80 \pm 9,95^{\mathbf{a b}}$ \\
GGT (U/L) & $0,01 \pm 0,01$ & $13,54 \pm 2,79$ & $6,40 \pm 2,59^{\mathbf{c}}$ & $0,85 \pm 0,36^{\mathbf{a b}}$ \\
TBIL (mg/dL) & $0,01 \pm 0,01$ & $0,88 \pm 0,21$ & $0,18 \pm 0,06^{\mathbf{c}}$ & $0,17 \pm 0,09^{\mathbf{b}}$ \\
TP (g/dL) & $5,90 \pm 0,33$ & $5,85 \pm 0,62$ & $6,45 \pm 0,25^{\mathbf{c}}$ & $6,51 \pm 0,39^{\mathbf{b}}$ \\
\hline GLOB (g/dL) & $4,07 \pm 0,35$ & $3,92 \pm 0,36$ & $4,47 \pm 0,24^{\mathbf{c}}$ & $4,22 \pm 0,24^{\mathbf{a b}}$ \\
\hline
\end{tabular}

$\overline{\mathbf{a}}$ diferença significante em relação a $\mathrm{CS}_{1} \mathrm{E}-\mathrm{CT} ;{ }^{\mathbf{b}}$ diferença significante em relação a $\mathrm{CS}_{1} \mathrm{~B}-\mathrm{FH}$ e ${ }^{\mathbf{c}}$ diferença significante em relação a $\mathrm{CS}_{0}$. $p<0,05$, teste de Mann-Whitney. ALB: albumina; ALKP: fosfatase alcalina; ALT: alanina aminotransferase; AST: aspartato aminotransferase; GGT: gama-glutamil transferase; TBIL: bilirrubina total; TP: proteína total; GLOB: globulina

Apesar da análise bioquímica mostrar que o tratamento melhorou as funções hepáticas, nem todas as alterações celulares analisadas apresentaram diferenças significantes quando o grupo $\mathrm{FH}$ foi comparado ao $\mathrm{CT}$.

A comparação intergrupos dos dados obtidos com o tecido hepático colhido na eutanásia dos animais (CT vs. FH) mostrou que o tratamento com os FHs aumentou significantemente a presença de células ovais, a vacuolização e reduziu a apoptose (Tabela 3 e Figura 16 A-B, E-F e G-H, respectivamente). Os demais parâmetros não mostraram alterações significantes. A comparação intragrupo, dos dados obtidos com a biópsia realizada antes do início do tratamento e na eutanásia do grupo FH (B-FH vs. FH), mostrou um aumento significante na presença de inclusões eosinofílicas (Tabela 3 e Figura 16 C-D), indicando que estas inclusões ocorreram algum tempo após o final da indução. Os demais parâmetros não mostraram alterações significantes. 
Tabela 3 - Alterações celulares hepáticas observadas na biópsia e na eutanásia dos animais induzidos à cirrose pela administração da TAA e tratados (FH) ou não (CT) com os FHs por 12 dias e eutanasiados imediatamente após o tratamento

\begin{tabular}{|c|c|c|c|}
\hline Parâmetros & $\begin{array}{r}\text { B-FH } \\
(n=13) \\
\end{array}$ & $\begin{array}{r}\text { CT } \\
(n=30) \\
\end{array}$ & $\begin{array}{r}\text { FH } \\
(n=13) \\
\end{array}$ \\
\hline Células ovais & $2,40 \pm 0,80$ & $2,03 \pm 0,72$ & $2,70 \pm 0,63^{a}$ \\
\hline Inclusões eosinofílicas & $1,40 \pm 0,51$ & $2,30 \pm 0,74$ & $2,31 \pm 0,63^{\mathbf{b}}$ \\
\hline Figura mitótica & $0,92 \pm 0,50$ & $1,83 \pm 0,60$ & $1,50 \pm 0,70$ \\
\hline Células binucleadas & $1,54 \pm 0,52$ & $1,43 \pm 0,50$ & $1,70 \pm 0,63$ \\
\hline Esteatose & $0,15 \pm 0,55$ & $0,13 \pm 0,35$ & $0,31 \pm 0,50$ \\
\hline Hemossiderina & $1,50 \pm 0,80$ & $1,80 \pm 0,80$ & $1,62 \pm 0,65$ \\
\hline Megalocitose & $1,92 \pm 0,80$ & $1,80 \pm 0,73$ & $1,54 \pm 0,52$ \\
\hline Vacuolização & $2,10 \pm 0,64$ & $2,00 \pm 0,45$ & $2,40 \pm 0,51^{\mathbf{a}}$ \\
\hline Lesão nuclear & $1,85 \pm 0,55$ & $2,13 \pm 0,63$ & $2,00 \pm 0,60$ \\
\hline Corpúsculo apoptótico & $2,10 \pm 0,95$ & $2,33 \pm 0,71$ & $1,62 \pm 0,65^{\mathrm{a}}$ \\
\hline
\end{tabular}

A figura $16 \mathrm{~A}-\mathrm{H}$ representa as diferenças observadas entre os grupos $\mathrm{CT}$ e $\mathrm{FH}$ nas alterações consideradas significantes. 

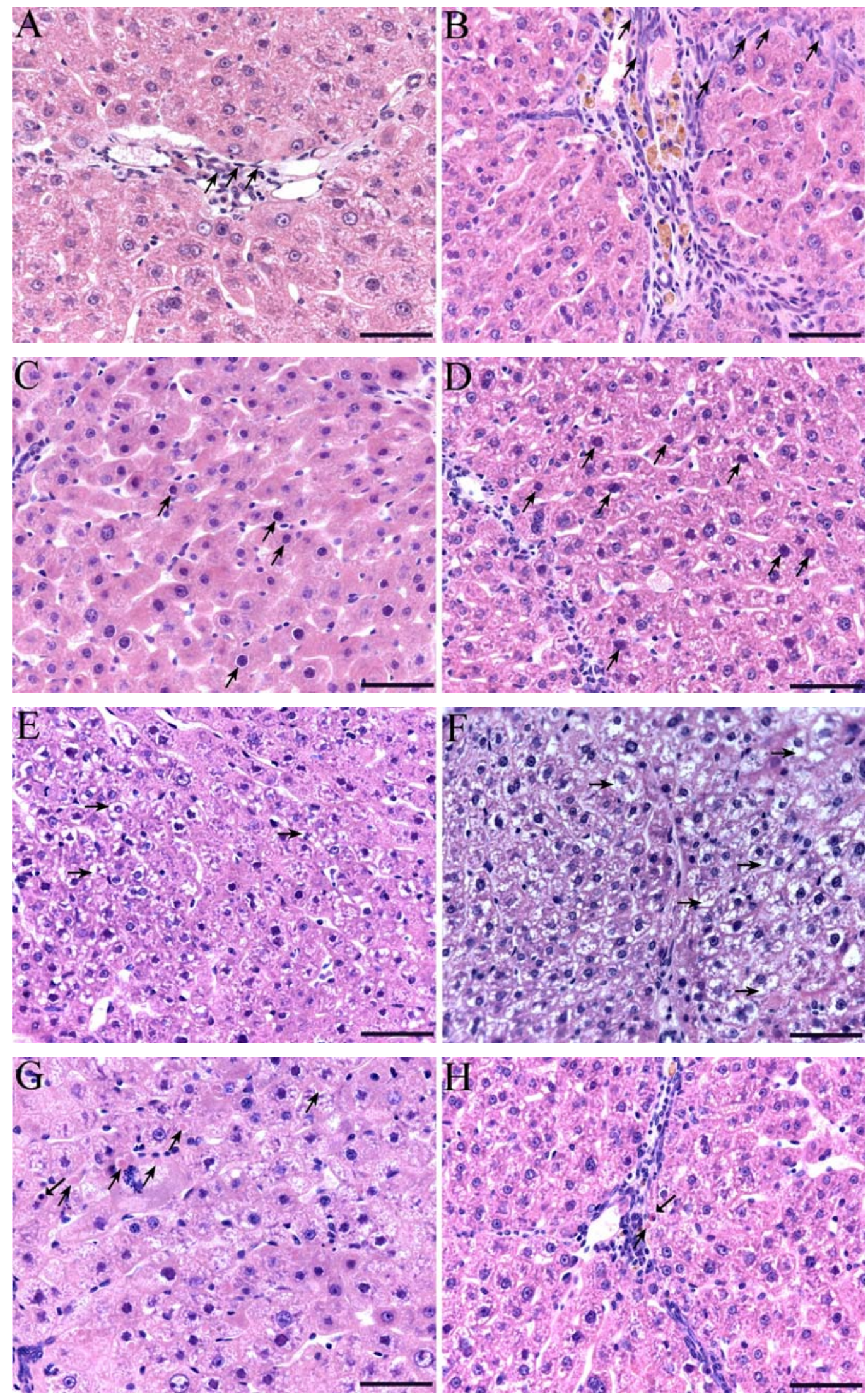

Figura 16 - Alterações celulares hepáticas (setas) observadas na eutanásia dos animais induzidos à cirrose pela administração da TAA e tratados (FH) ou não (CT) com os FHs por 12 dias e eutanasiados imediatamente após o tratamento: células ovais, A) grupo CT e B) $\mathrm{FH}$; inclusões eosinofílicas, C) grupo CT e D) FH; vacuolização, E) grupo CT e F) FH; corpúsculos apoptóticos, G) grupo CT e H) FH. Barra de escala $=50 \mu \mathrm{m}$ 


\subsubsection{O tratamento com os FHs aumentou a deposição de mucopolissacarídeos ácidos e reduziu o acúmulo de glicogênio}

A comparação entre os dados obtidos com a biópsia, realizada antes do início do tratamento (B-FH), e com a eutanásia após o seu término (grupo $\mathrm{FH}$ ) mostrou que a frequência no depósito de mucopolissacarídeos ácidos aumentou pós-tratamento (Tabela 4). As porcentagens das deposições classificadas como pouca e moderada aumentaram respectivamente, de 7,69 para 15,38 e de 7,69 para 30,77. Em adição, os animais do grupo FH apresentaram uma frequência maior no depósito de mucopolissacarídeos ácidos em comparação ao grupo CT, representada pelo aumento na classificação moderada de 3,33 para 30,77. Entretanto, o tratamento evitou que o quadro evoluísse para uma deposição intensa $(0,00 \%)$, o que foi observado apenas no grupo CT $(3,33 \%)$.

A tabela 4 mostra que a deposição de glicogênio também aumentou após o tratamento. A comparação entre B-FH e FH mostrou que as deposições moderada e intensa aumentaram respectivamente, de 15,38 e 0,00 para 30,77 e 7,69. Por outro lado, a compração entre os grupos $\mathrm{CT}$ e FH mostrou que o tratamento reduziu a deposição de glicogênio classificada como moderada em $23,08 \%$ (de 40,00 para $30,77 \%$ ) e a intensa em $82,25 \%$ (de 43,33 para 7,69), em comparação com o grupo CT. 
Tabela 4 - Frequência da deposição de mucopolissacarídeos ácidos e de glicogênio observada na biópsia e na eutanásia dos animais induzidos à cirrose pela administração da TAA e tratados (FH) ou não (CT) com os FHs e eutanasiados imediatamente após o tratamento

\begin{tabular}{|c|c|c|c|c|c|}
\hline \multirow[b]{2}{*}{ Depósito } & \multirow[b]{2}{*}{ Grupos (n) } & \multicolumn{4}{|c|}{ Frequência (\%) } \\
\hline & & Ausente & Pouca & Moderada & Intensa \\
\hline \multirow{3}{*}{$\begin{array}{l}\text { Mucopolissacarídeos } \\
\text { ácidos }\end{array}$} & B-FH $(n=13)$ & 84,62 & 7,69 & 7,69 & 0,00 \\
\hline & $\mathbf{C T}(\mathrm{n}=30)$ & 73,33 & 20,00 & 3,33 & 3,33 \\
\hline & $\mathbf{F H}(n=13)$ & 53,85 & 15,38 & 30,77 & 0,00 \\
\hline \multirow[t]{3}{*}{ Glicogênio } & B-FH $(n=13)$ & 0,00 & 84,62 & 15,38 & 0,00 \\
\hline & $\mathbf{C T}(\mathrm{n}=30)$ & 0,00 & 16,67 & 40,00 & 43,33 \\
\hline & $\mathbf{F H}(\mathrm{n}=13)$ & 0,00 & 61,54 & 30,77 & 7,69 \\
\hline
\end{tabular}

\subsubsection{O tratamento não alterou a atividade histológica e o estadiamento da fibrose/cirrose hepáticas}

O índice de atividade histológica (IAH) obtido através da análise da atividade necroinflamatória classificada segundo os critérios de Knodell et al. (1981) e modificados por Ishak et al. (1995) demonstrou que o tratamento não alterou a atividade histológica tecidual imediatamente após o tratamento. A comparação dos dados, obtidos após análise do tecido hepático colhido na eutanásia, mostrou que as diferenças observadas entre os grupos CT (7,70 $\pm 1,50)$ e $\mathrm{FH}(7,45 \pm 0,70)$ não foram estatisticamente significantes (Figura 17 A e B). 

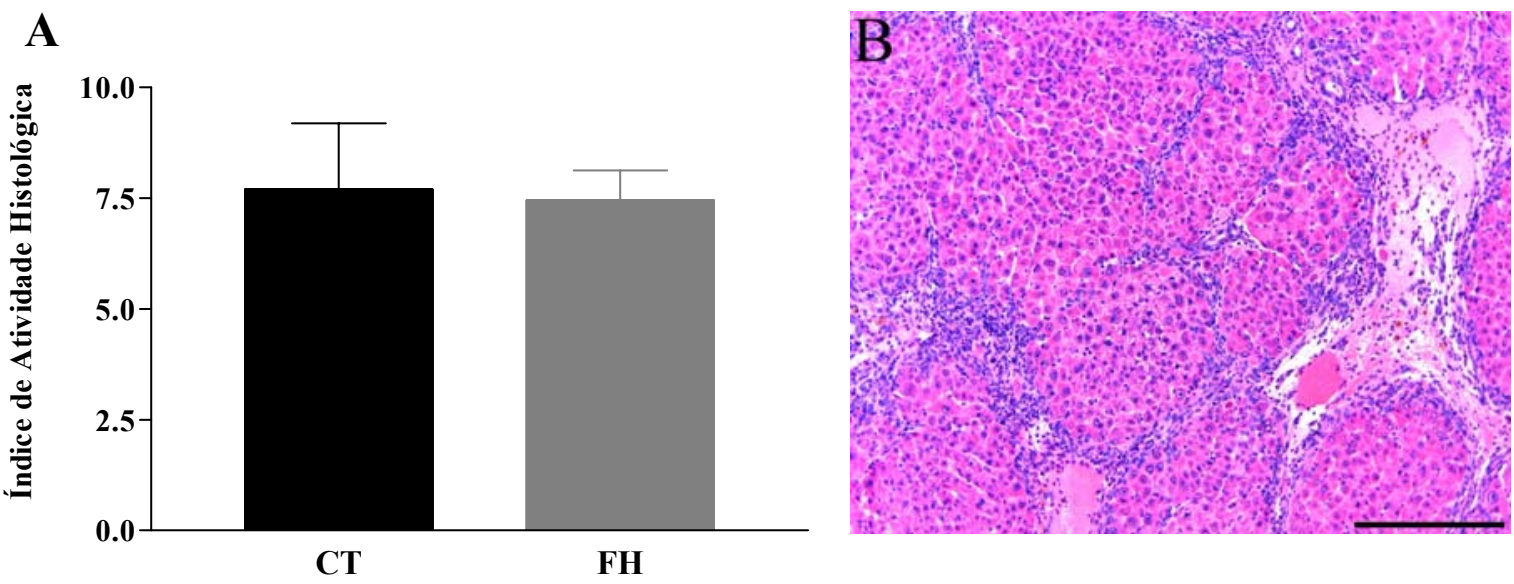

Figura 17 - A) Índice de atividade histológica, obtido através da análise da atividade necro-inflamatória classificada segundo os critérios de Ishak et al. (1995), realizada no tecido hepático dos animais induzidos à cirrose pela administração da TAA e tratados $(\mathrm{FH}, \mathrm{n}=13)$ ou não $(\mathrm{CT}$, $\mathrm{n}=30$ ) com os FHs por 12 dias e eutanasiados imediatamente após o tratamento. Diferenças não significantes, $p>0,05$, teste $t$-Student. B) Aspecto do tecido hepático cirrótico, coloração em HE, barra de escala $=200 \mu \mathrm{m}$

A análise do estadiamento do grau da fibrose pelos critérios modificados por Ishak et al. (1995) realizada nos grupos submetidos à indução da cirrose e tratados $(\mathrm{FH}, \mathrm{n}=13)$ ou não $(\mathrm{CT}, \mathrm{n}=30)$ com os FHs não apresentou diferenças significantes entre os grupos. A graduação nos grupos CT e FH atingiu respectivamente, 5,70 \pm 0,55 e 5,23 $\pm 0,90$ (Figura 18 A e B).
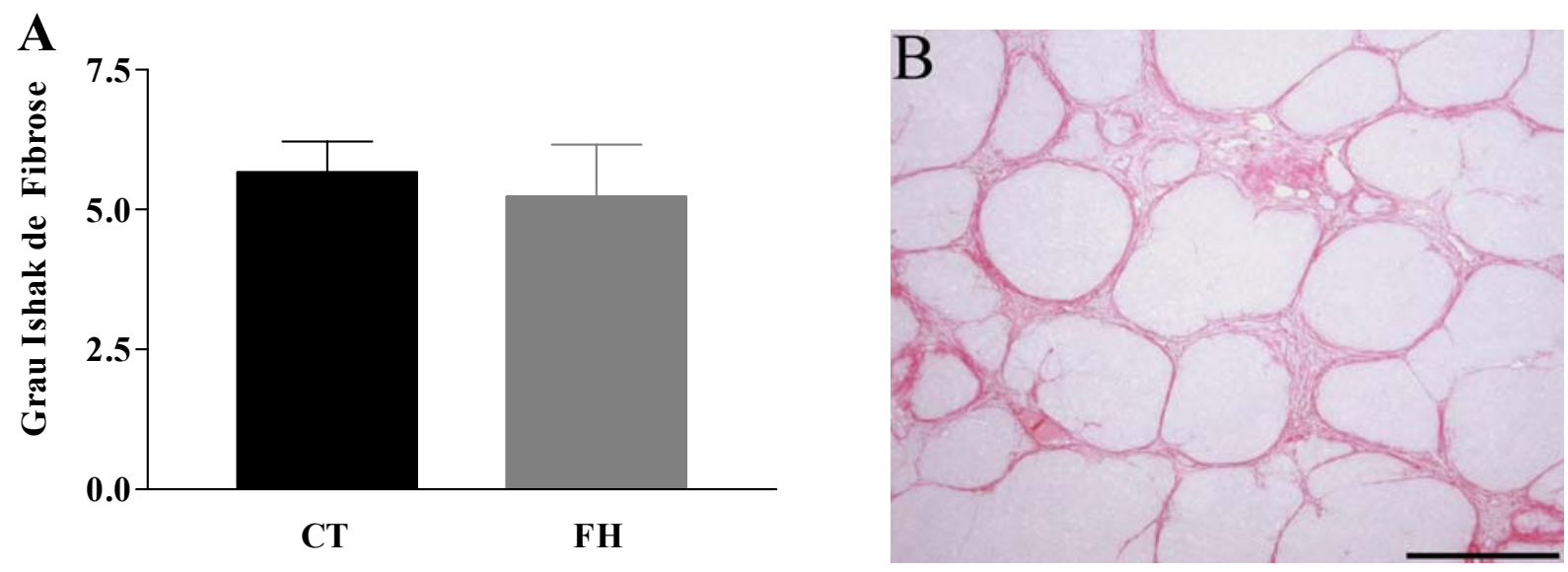

Figura 18 - A) Estadiamento da fibrose segundo os critérios de Ishak et al. (1995) no tecido hepático obtido na eutanásia dos animais induzidos à cirrose pela administração da TAA e tratados $(\mathrm{FH}, \mathrm{n}=13)$ ou não $(\mathrm{CT}, \mathrm{n}=30)$ com os FHs por 12 dias e eutanasiados imediatamente após o tratamento. Diferenças não significantes, $p>0,05$, teste de Mann-Whitney. B) Aspecto do tecido hepático, coloração picrossírius, barra de escala $=200 \mu \mathrm{m}$ 


\subsubsection{O tratamento não alterou a proliferação dos ductos hepáticos}

A análise da proliferação de ductos, no tecido hepático dos animais submetidos à indução da cirrose pela TAA e tratados (FH) ou não (CT) com o FHs por 12 dias, mostrou que o tratamento não alterou este parâmetro (Figura 19 A-C). A comparação entre o tecido obtido na biópsia, realizada antes do início do tratamento (B-FH) e o obtido na eutanásia após o tratamento $(\mathrm{FH})$, mostrou que o tratamento aumentou a proliferação dos ductos, apresentando respectivamente uma elevação de 0,23 $\pm 0,44$ para 1,50 $\pm 1,05$. Entretanto, as diferenças não foram significantes quando os dados da eutanásia do grupo tratado $(\mathrm{FH}$, escore $1,50 \pm 1,05$ ) foram comparados aos do CT (escore $0,90 \pm 1,10)$.

A
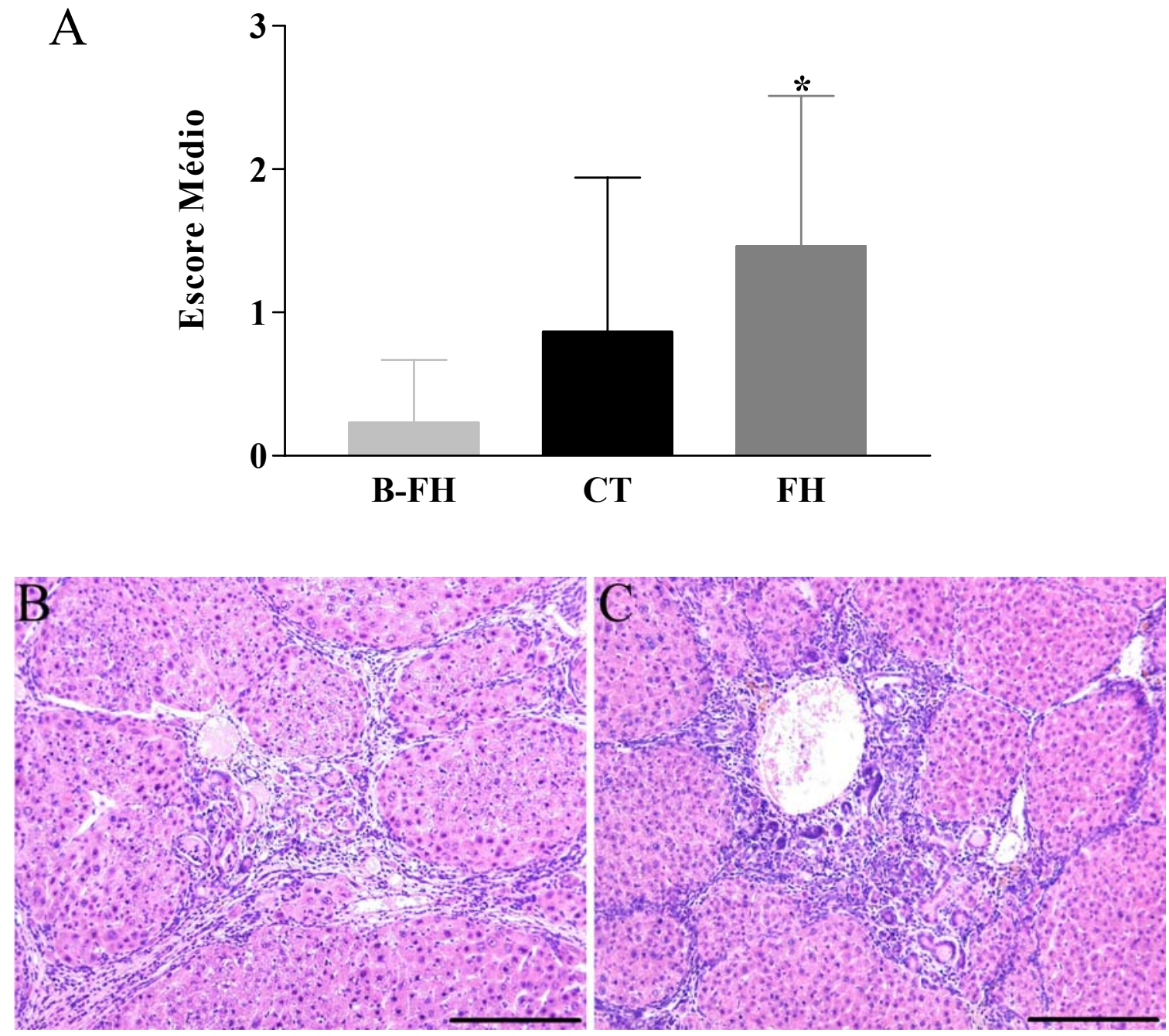

Figura 19 - A) Proliferação de ductos observada na biópsia e na eutanásia do tecido hepático dos animais induzidos à cirrose pela administração da TAA e tratados $(\mathrm{FH}, \mathrm{n}=13)$ ou não $(\mathrm{CT}, \mathrm{n}=30) \mathrm{com}$ os FHs por 12 dias e eutanasiados imediatamente após o tratamento. * diferença significante em relação a B-FH, $p<0,05$, teste de Mann-Whitney. B) Proliferação no tecido obtido na biópsia (B-FH) e C) na eutanásia do grupo FH. Coloração em HE, barra de escala $=200 \mu \mathrm{m}$ 


\subsubsection{O tratamento reduziu a deposição de colágeno}

Apesar do grupo FH apresentar o mesmo estadiamento da fibrose em relação ao grupo CT, o tratamento com os FHs reduziu significantemente a proporção volumétrica do colágeno determinada no tecido hepático corado em picrossírius (Tabela 5 e Figura 20 A-C). O colágeno interlobular analisado no tecido hepático do grupo $\mathrm{FH}$, colhido no momento da eutanásia, apresentou redução de 31,75\% (Figura 20 B) em comparação ao grupo CT (Figura 20 C). A comparação intragrupo (B-FH vs. FH) não apresentou diferenças significantes, indicando que a deposição do colágeno ocorreu algum tempo depois do final da indução.

Tabela 5 - Proporção volumétrica do colágeno inter e intralobular no tecido hepático obtido na biópsia e na eutanásia dos animais induzidos à cirrose pela administração da TAA e tratados (FH) ou não (CT) com os FHs por 12 dias e eutanasiados imediatamente após o tratamento

\begin{tabular}{cccc}
\hline Tipo de Colágeno & B-FH & CT & FH \\
& $(\mathbf{n = 1 3 )}$ & $(\mathbf{n = 3 0 )}$ & $(\mathbf{n = 1 3 )}$ \\
\hline Interlobular & $8,95 \pm 2,56$ & $10,02 \pm 1,92$ & $6,84 \pm 1,76^{\mathbf{a}}$ \\
Intralobular & $0,30 \pm 0,07$ & $0,23 \pm 0,09$ & $0,20 \pm 0,03$ \\
\hline
\end{tabular}

a diferença significante em relação ao $\mathrm{CT}, p<0,05$, teste $t$-Student 

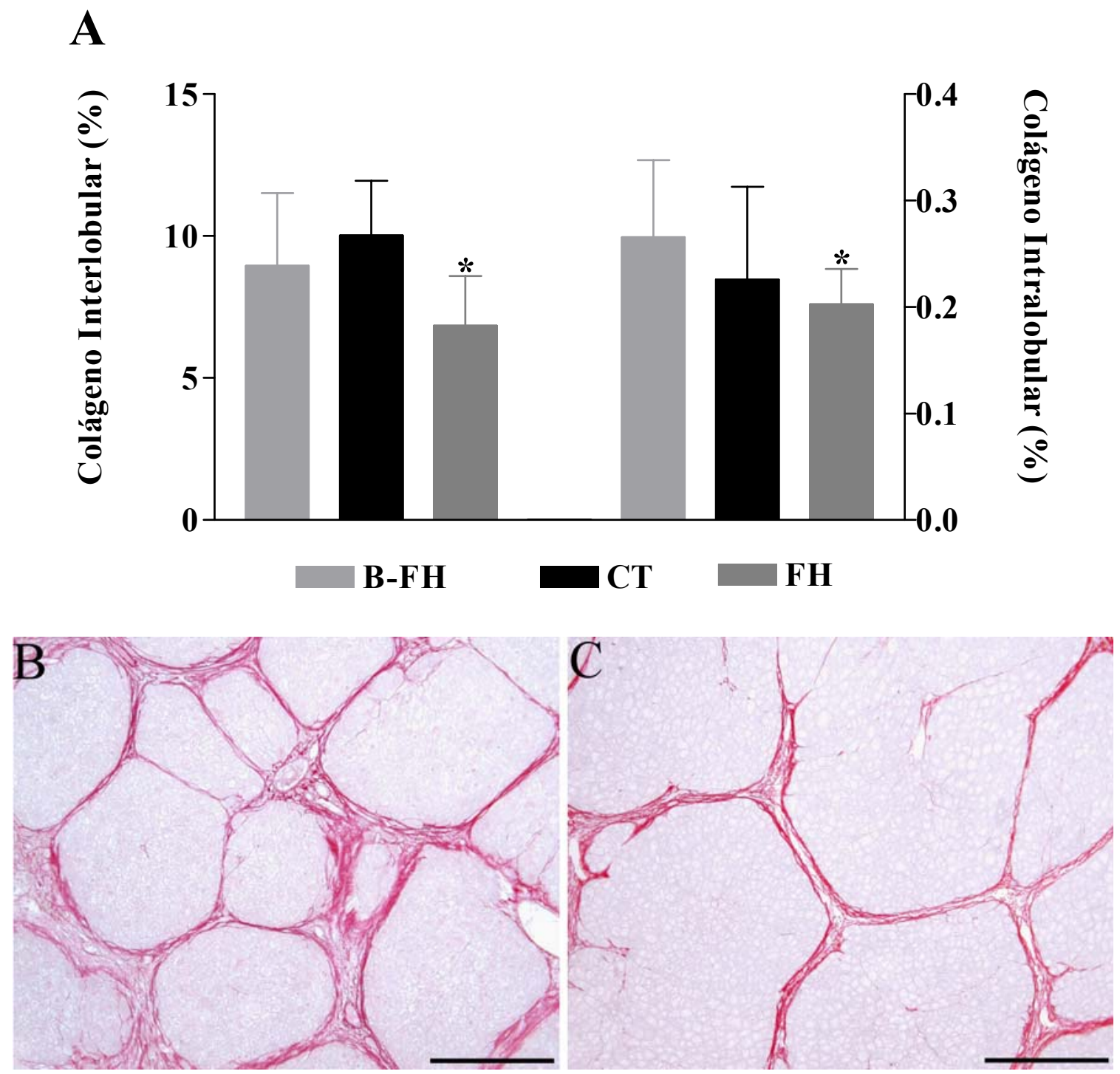

Figura 20 - A) Proporção volumétrica da área ocupada pelos colágenos inter e intralobulares no tecido hepático obtidos na biópsia e na eutanásia dos animais induzidos à cirrose pela administração da TAA e tratados $(\mathrm{FH}, \mathrm{n}=13)$ ou não $(\mathrm{CT}, \mathrm{n}=30)$ com os $\mathrm{FHs}$ por 12 dias e eutanasiados imediatamente após o tratamento. " diferença significante em relação ao $\mathrm{CT}, p<0,05$, teste $t$ Student. B) tecido hepático do grupo $\mathrm{CT}$ e C) grupo $\mathrm{FH}$, coloração picrossírius, barra de escala $=200 \mu \mathrm{m}$

A marcação por imunofluorescência dos colágenos tipo I (Figura 21 A e B) e III (Figura $21 \mathrm{C}$ e D) no tecido hepático obtido na eutanásia dos animais, também demonstrou que apesar do mesmo estadiamento da fibrose, o grupo FH apresentou menor deposição dos colágenos interlobular e intralobular (Figura 21 B e D) relação ao grupo CT (Figura 21 A e C). Não foi realizada a quantificação destes dois tipos de colágeno, as fotos são apenas ilustrativas e também evidenciam a predominância do colágeno tipo 1 em relação ao tipo 3, característica da cirrose hepática. 

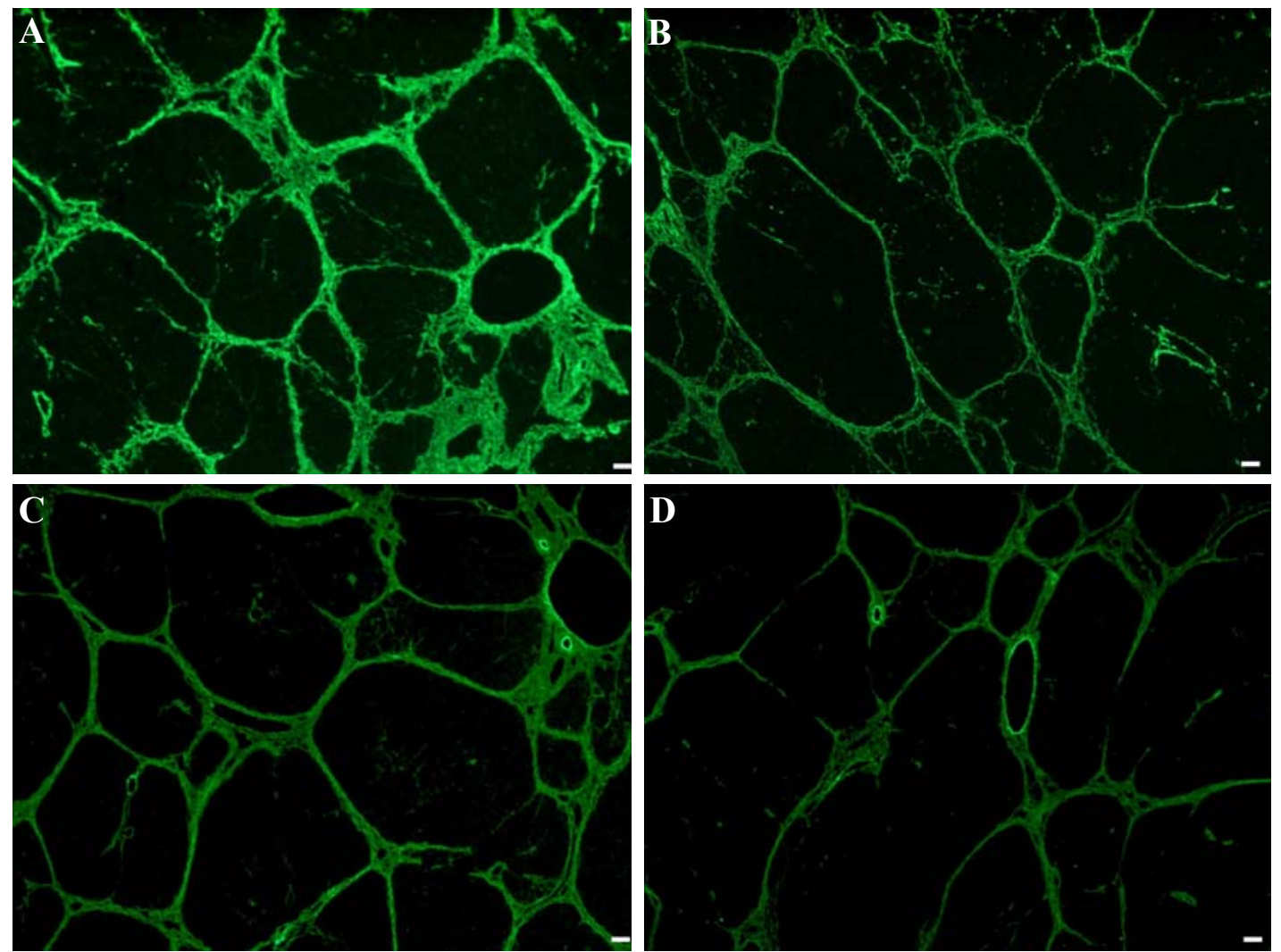

Figura 21 - Imunofluorescência para os colágenos tipo 1 e 3 no tecido hepático obtido na eutanásia dos animais submetidos à indução da cirrose pela administração da TAA e tratados $(\mathrm{FH})$ ou não (CT) com os FHs por 12 dias e eutanasiados imediatamente após o tratamento. Observar a menor deposição dos colágenos interlobular e intralobular em relação ao grupo CT. Colágeno tipo 1: A, grupo CT e B, grupo FH. Colágeno tipo 3: C, grupo CT e D, FH. Barra de escala $=50 \mu \mathrm{m}$

\subsubsection{O tratamento reduziu a ativação das células estreladas}

A quantificação células positivas para a imunomarcação da $\alpha$-SMA, realizada no tecido hepático obtido na eutanásia dos animais, mostrou que o grupo tratado com os FHs (FH) apresentou redução significante de 53,17\% $(1,40 \pm 1,40)$, em comparação ao grupo CT $(3,00 \pm 1,16)$, conforme pode ser observado na figura $22 \mathrm{~A}-\mathrm{C}$. 
A
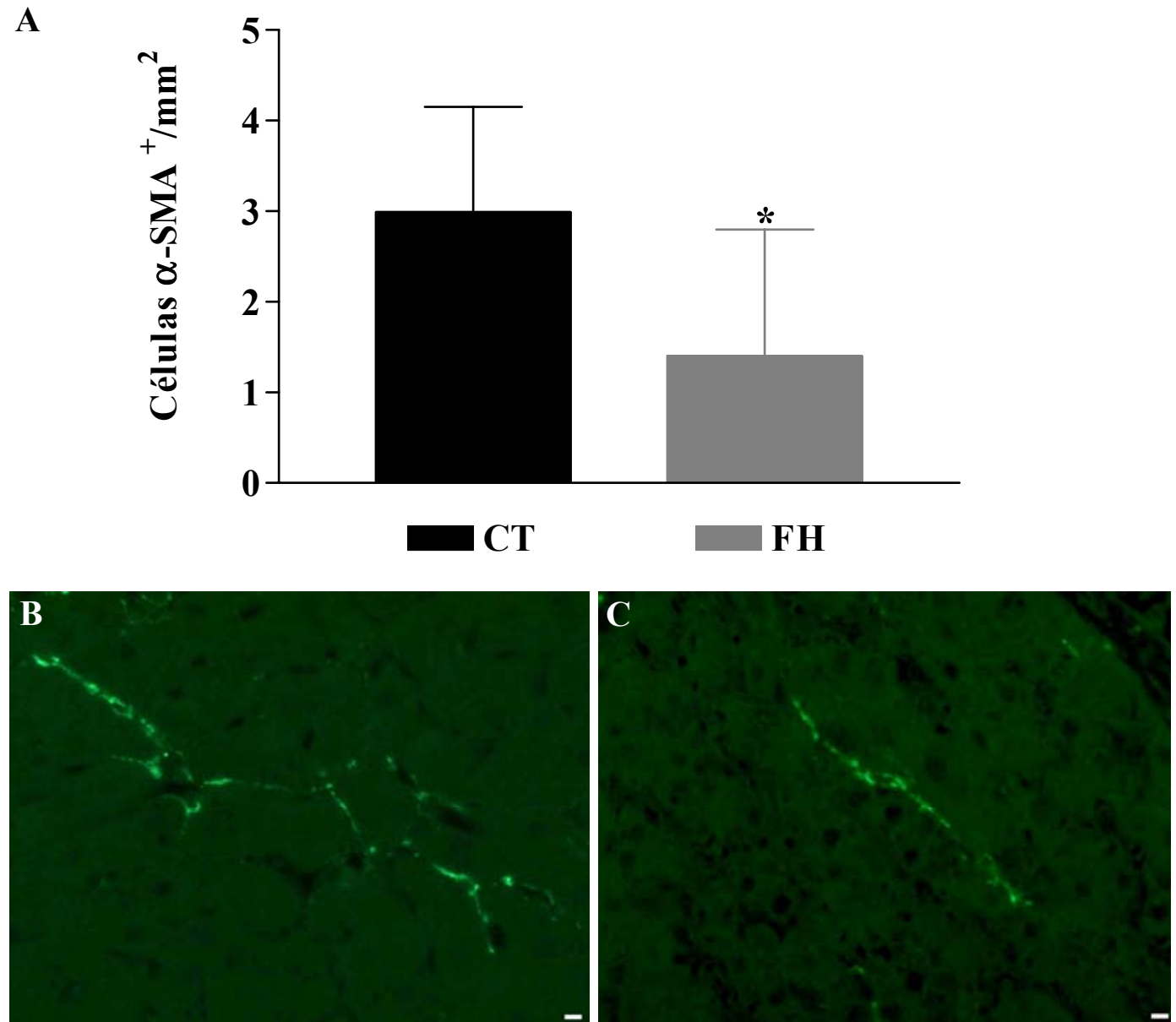

Figura 22 - Análise da imunomarcação das células positivas para $\alpha$-SMA realizada no tecido hepático obtido na eutanásia dos animais submetidos à indução da cirrose pela TAA e tratados (FH) ou não (CT) com os FHs por 12 dias e eutanasiados imediatamente após o tratamento. A) quantificação das células $\alpha-\mathrm{SMA}^{+}$por $\mathrm{mm}^{2}$ de tecido. * diferença significante em relação $\mathrm{CT}, p<0,05$, teste de Mann-Whitney. B) imunofluorescência evidenciando marcação no grupo $\mathrm{CT}$ e em $\mathbf{C}$ ) no grupo $\mathrm{FH}$. Barra de escala $=5 \mu \mathrm{m}$

\subsubsection{O tratamento não reduziu a proliferação dos hepatócitos}

A análise dos efeitos do tratamento sobre a proliferação dos hepatócitos pela imunomarcação do PCNA, realizada no tecido hepático obtido na eutanásia dos animais dos grupos CT e FH, mostrou que o tratamento não alterou a proliferação dos hepatócitos. As diferenças observadas, entre a porcentagem de células PCNA positivas do grupo FH $(5,27 \pm$ $2,90)$ e do grupo CT $(6,88 \pm 2,80)$, não foram consideradas significantes (Figura 23 A-C). 
A
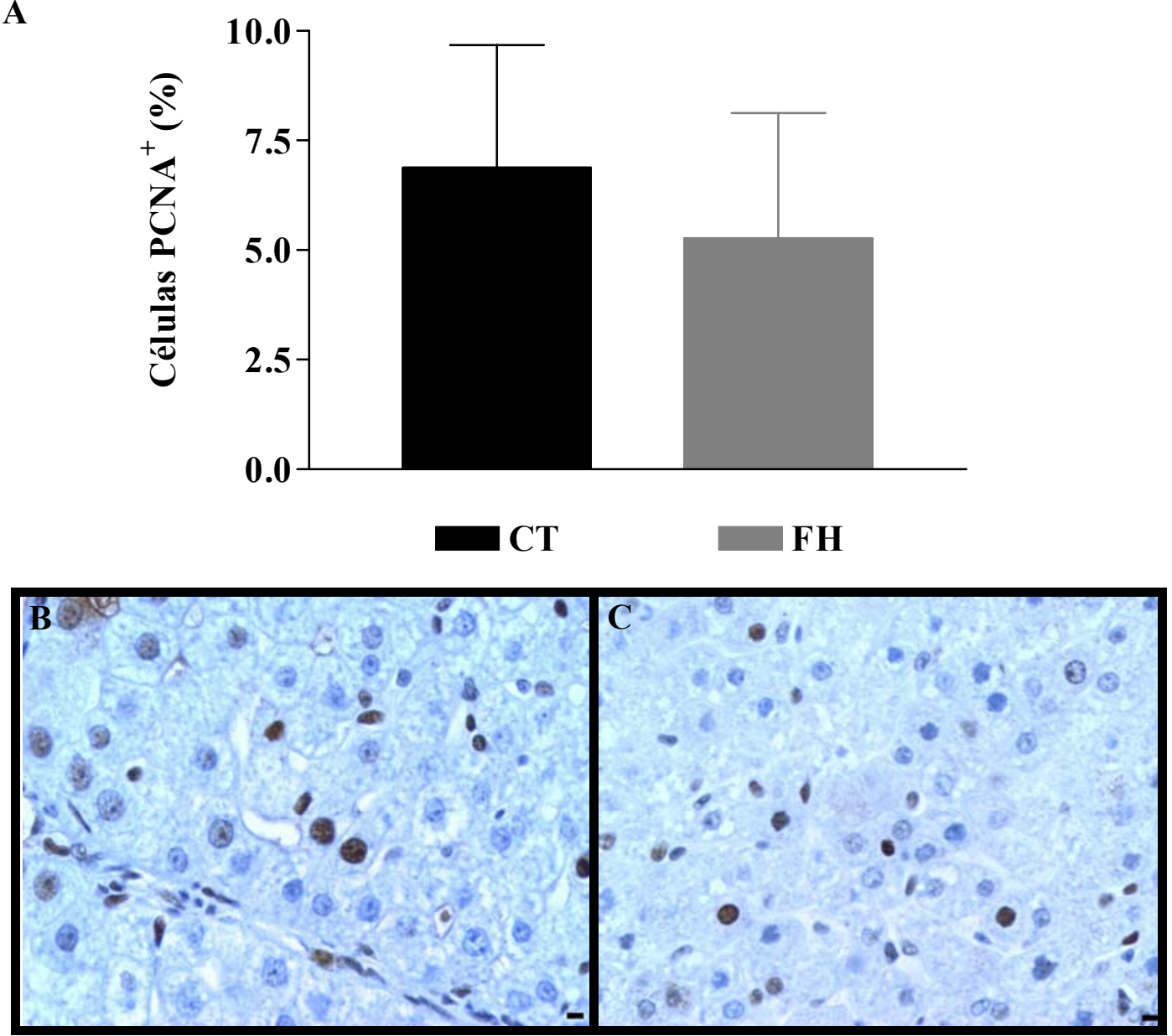

Figura 23 - A) Análise da imunomarcação das células positivas para PCNA realizada no tecido hepático obtido na eutanásia dos animais submetidos à indução da cirrose pela TAA e tratados $(\mathrm{FH})$ ou não $(\mathrm{CT})$ com os $\mathrm{FHs}$ por 12 dias e eutanasiados imediatamente após o tratamento. Diferenças não significantes, $p>0,05$, teste de Mann-Whitney. B) grupo $\mathrm{CT}$ e C) grupo FH. Barra de escala $=5 \mu \mathrm{m}$

\subsubsection{O tratamento alterou os mecanismos moleculares envolvidos na fibrogênese hepática}

A figura 24 A-F mostra a avaliação da expressão dos principais genes envolvidos na fibrogênese hepática por PCR em tempo real, dos animais submetidos à indução da cirrose pela TAA e tratados (FH) ou não (CT) com os FHs por 12 dias e eutanasiados imediatamente após o tratamento. $\mathrm{Na}$ análise do colágeno tipo 1 (Figura $24 \mathrm{~A}$ ), o principal tipo de colágeno 
depositado na fibrose hepática, os animais do FH apresentaram redução significante $(0,40 \pm$ $0,21)$ na expressão deste gene em relação ao grupo CT $(1,00 \pm 0,22)$. Entretanto, na avaliação da expressão do TGF $\beta$-1 (Figura 24 B), importante ativador das células estreladas, e portanto, um dos responsáveis indiretos pela deposição do colágeno, não foram encontradas diferenças significantes entre os grupos FH $(0,92 \pm 0,47)$ e CT $(1,00 \pm 0,25)$. A expressão da TIMP-1 (Figura $24 \mathrm{C}$ ), a principal inibidora das metaloproteinases, aumentou nos animais do grupo FH $(2,18 \pm 0,56)$ em relação ao grupo CT $(1,00 \pm 0,29)$. Na análise das metaloproteinases MMP-2 e MMP-13 (Figura 24 D e E), responsáveis pela degradação do colágeno e de outros componentes da matriz extracelular, apenas a MMP-13 apresentou aumento significante na expressão gênica. A MMP-13 está relacionada à degradação dos colágenos tipo 1 e 3 . A expressão deste gene no grupo $\mathrm{FH}(8,29 \pm 2,63)$ foi aproximadamente 8 vezes superior ao observado no CT $(1,00 \pm 0,34)$. Na última análise foi avaliada a expressão do gene PLAU, responsável pela conversão de plasminogênio em plasmina, a qual tem ação proteolítica sobre os componentes da matriz extracelular e efeito ativador sobre as MMPs, e foi observado que o tratamento com os FHs aumentou $(1,40 \pm 0,43$ vs. 1,00 $\pm 0,11)$ significantemente a expressão deste gene (Figura 24F). 
Colágeno Tipo 1

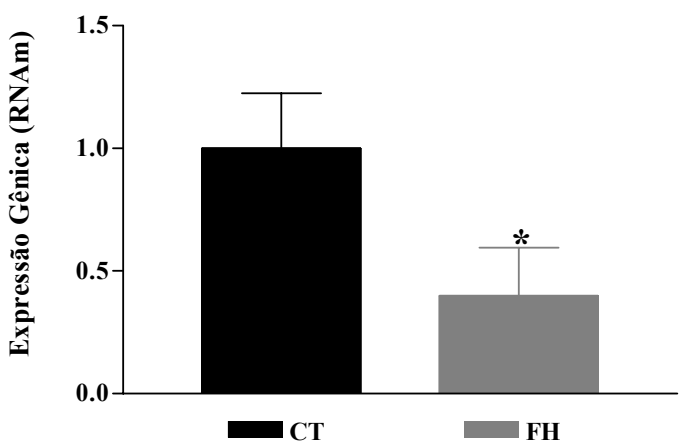

TIMP-1

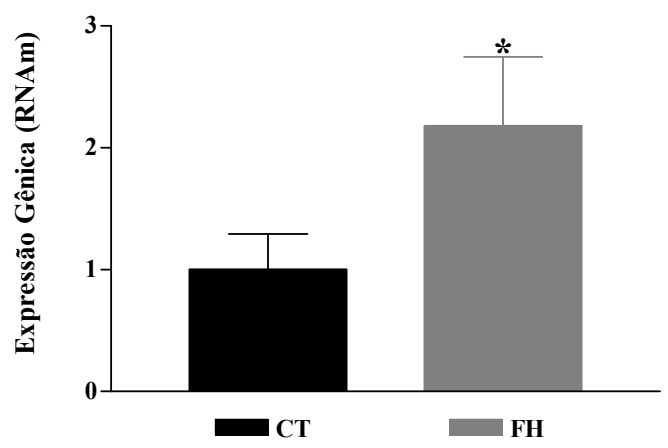

MMP-13

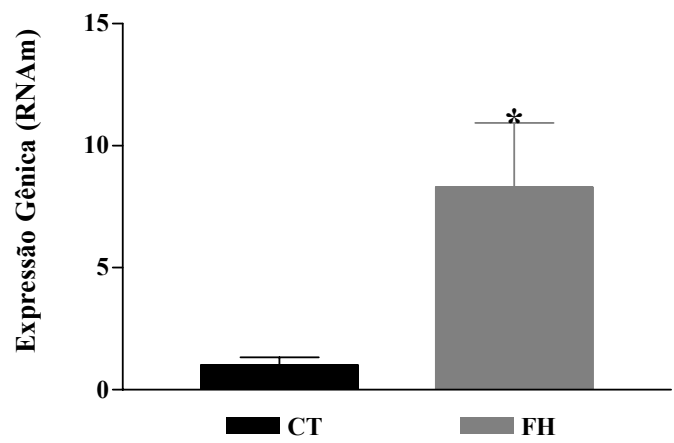

A

TGF $\beta-1$

B

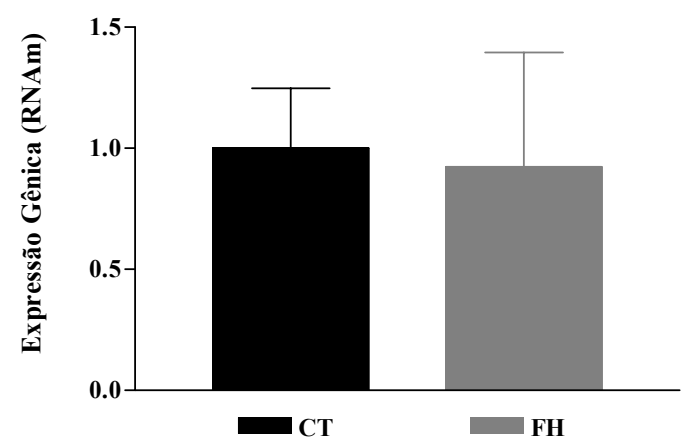

C

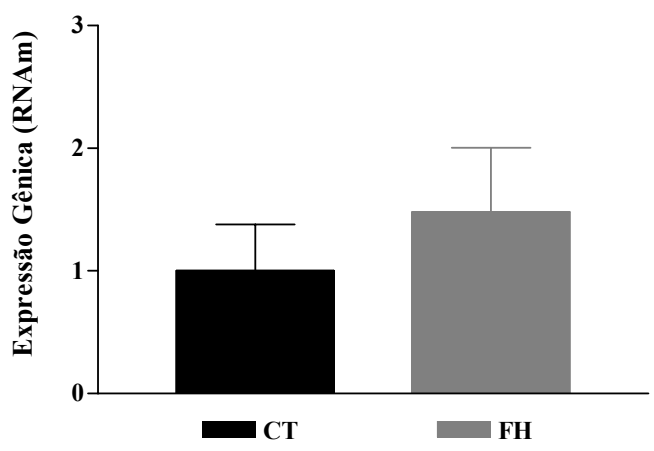

$\mathbf{E}$

PLAU

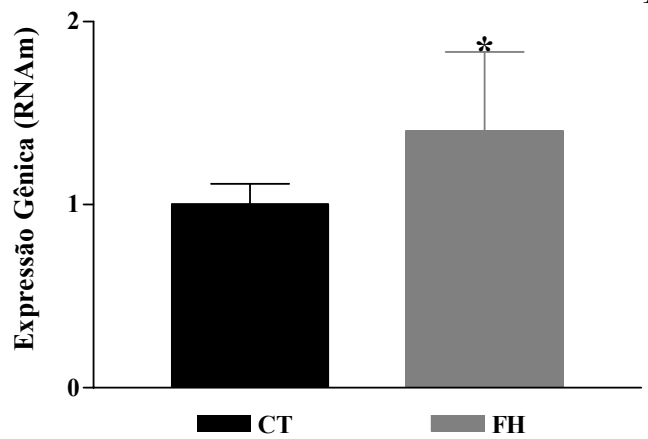

Figura 24 - Expressão relativa dos principais genes envolvidos na fibrogênese hepática obtida pela análise do fígado dos animais submetidos à indução da cirrose pela TAA e tratados $(\mathrm{FH})$ ou não (CT) com os FHs por 12 dias e eutanasiados imediatamente após o tratamento. A) Colágeno tipo 1; B) TGF $\beta-1$; C) TIMP-1; D) MMP-2; E) MMP-13 e F) PLAU. * diferença significante em relação ao CT, $p<0,05$, teste de Mann-Whitney 


\subsection{RESULTADOS DOS ANIMAIS CIRRÓTICOS TRATADOS $\left(\mathrm{FH}^{+60 \mathrm{~d}}\right)$ OU NÃO (CT) COM OS FHS POR 12 DIAS E EUTANASIADOS 60 DIAS PÓS-TRATAMENTO}

Serão apresentados os resultados obtidos com as análises realizadas nos grupos $\mathrm{FH}^{+60 \mathrm{~d}}$ e no seu CT. Conforme já comentado, os dados dos dois grupos foram comparados com as biópsias, obtidas dos animais do próprio grupo, gerando uma comparação intragrupo.

\subsubsection{A administração da TAA, o tratamento com os FHs e/ou o período de 60 dias pós- tratamento não provocaram aumento na taxa de mortalidade dos animais}

$\mathrm{O}$ grupo $\mathrm{FH}^{+60 \mathrm{~d}}$ não apresentou nenhum obtido, entretanto, o seu grupo CT apresentou $13,33 \%$ de mortalidade, correspondente a 2 animais. Os dois óbitos ocorreram no final do período de indução da cirrose.

\subsubsection{O peso médio dos animais não se alterou 60 dias pós-tratamento}

O gráfico 4 mostra a evolução do peso corporal médio dos animais dos grupos CT e $\mathrm{FH}^{+60 \mathrm{~d}}$. Os dois grupos apresentaram um comportamento semelhante ao longo de toda a indução da cirrose pela TAA ( $1^{\mathrm{a}}$ a $14^{\mathrm{a}}$ semanas). Entretanto, nas $7^{\mathrm{a}}, 10^{\mathrm{a}}$ e $11^{\mathrm{a}}$ semanas os animais que seriam tratados com os FHs apresentaram pesos estatisticamente maiores em relação ao grupo CT. Durante o tratamento, da $14^{\mathrm{a}}$ até a $16^{\mathrm{a}}$ semana, o peso dos animais do grupo $\mathrm{FH}^{+60 \mathrm{~d}}$ apresentou um aumento estatisticamente significante em comparação ao grupo CT. Da $17^{\mathrm{a}}$ a $21^{\mathrm{a}}$ semana, o peso médio do grupo $\mathrm{FH}^{+60 \mathrm{~d}}$ mostrou redução estatisticamente significante, igualando-se ao grupo CT na eutanásia (27 semana). 


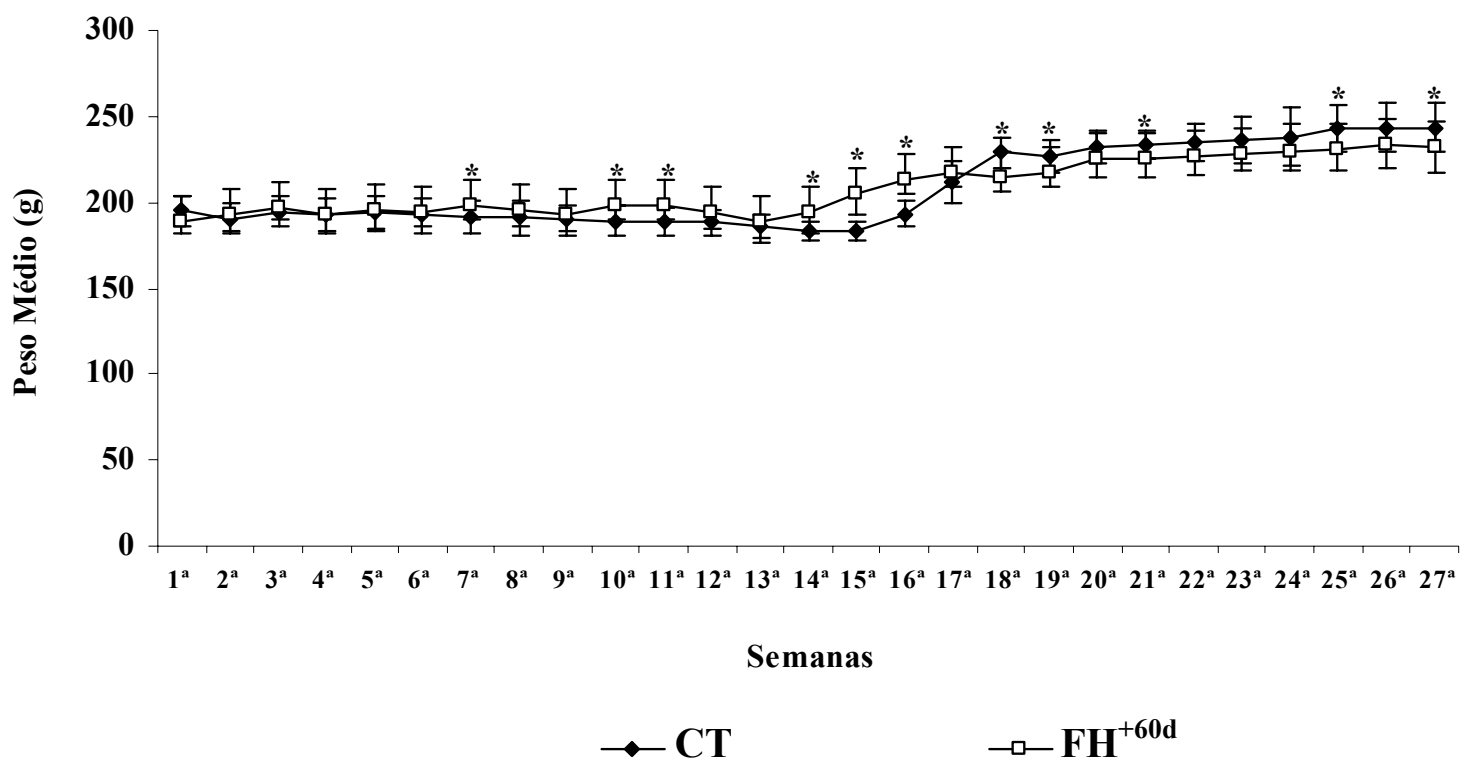

Gráfico 4 - Evolução do peso corporal médio dos animais submetidos à indução da cirrose pela TAA, tratados $\left(\mathrm{FH}^{+60 \mathrm{~d}}\right)$ ou não $(\mathrm{CT})$ com os fatores $\mathrm{FH}$ por 12 dias e eutanasiados 60 dias pós-tratamento: * diferença estatística significante em relação ao CT, $p<0,05$, teste t-Student

\subsubsection{A densidade do fígado reduziu 60 dias pós-tratamento}

A tabela 6 relaciona os valores obtidos com os parâmetros biométricos analisados póseutanásia dos animais submetidos ao modelo da cirrose pela administração da TAA e tratados $\left(\mathrm{FH}^{+60 \mathrm{~d}}\right)$ ou não $(\mathrm{CT})$ com os $\mathrm{FHs}$ por 12 dias e eutanasiados 60 dias pós-tratamento. Os animais do grupo $\mathrm{FH}^{+60 \mathrm{~d}}$ apresentaram redução estatisticamente significante, do peso corporal e da densidade do fígado, em relação ao grupo CT. Os demais parâmetros não apresentaram diferenças significantes. 
Tabela 6 - Parâmetros biométricos médios obtidos após a eutanásia dos animais submetidos à indução da cirrose pela TAA, tratados $\left(\mathrm{FH}^{+60 d}\right)$ ou não $(\mathrm{CT})$ com os fatores $\mathrm{FH}$ por 12 dias e eutanasiados 60 dias pós-tratamento

\begin{tabular}{|c|c|c|}
\hline Parâmetros & $\begin{array}{c}\text { CT } \\
(\mathrm{n}=13)\end{array}$ & $\begin{array}{l}\mathbf{F H}^{+60 d} \\
(\mathrm{n}=15)\end{array}$ \\
\hline Peso Corporal (g) & $251,70 \pm 13,11$ & $231,73 \pm 15,00 *$ \\
\hline Peso da Carcaça (g) & $200,30 \pm 13,01$ & $190,40 \pm 12,00$ \\
\hline Peso do Fígado (g) & $8,70 \pm 1,10$ & $8,30 \pm 1,00$ \\
\hline Peso das Vísceras (g) & $45,45 \pm 4,41$ & $41,42 \pm 4,72$ \\
\hline Índice Vísceras/Peso Corporal (\%) & $18,04 \pm 1,20$ & $17,90 \pm 1,50$ \\
\hline Índice Hepato/Corporal (\%) & $4,32 \pm 0,34$ & $4,40 \pm 0,50$ \\
\hline Índice Hepatossomático (\%) & $3,44 \pm 0,40$ & $3,60 \pm 0,34$ \\
\hline Volume do Fígado $\left(\mathrm{cm}^{3}\right)$ & $8,00 \pm 1,00$ & $7,90 \pm 0,90$ \\
\hline Densidade do Fígado $\left(\mathrm{cm}^{3} / \mathrm{g}\right)$ & $1,09 \pm 0,01$ & $1,05 \pm 0,02 *$ \\
\hline
\end{tabular}

* diferença estatística significante em relação ao CT, $p<0,05$, teste $t$-Student

Os gráficos 5 e 6 representam os resultados discriminados na tabela 6 . 


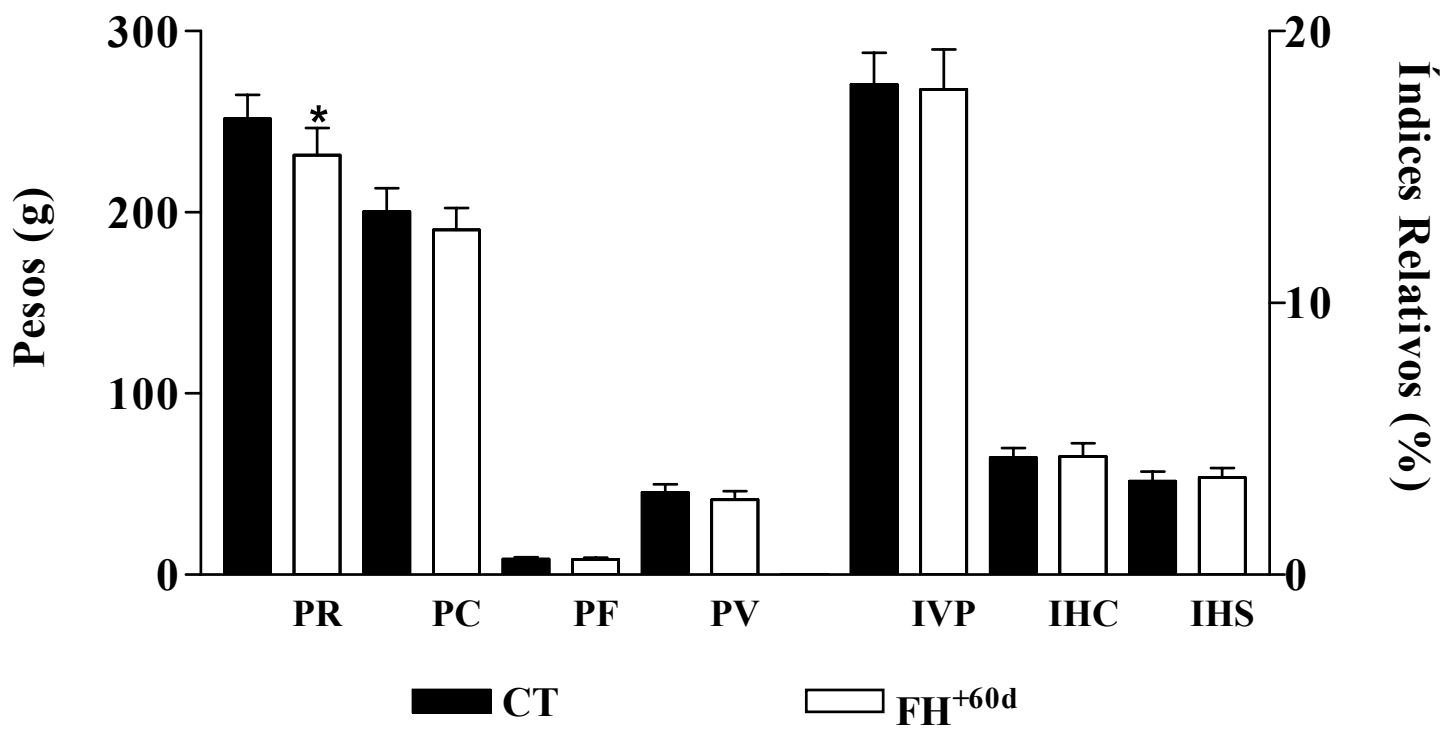

Gráfico 5 - Parâmetros biométricos obtidos após a eutanásia dos animais submetidos à indução da cirrose pela TAA, tratados $\left(\mathrm{FH}^{+60 d}\right)$ ou não $(\mathrm{CT})$ com os $\mathrm{FHs}$ por 12 dias e eutanasiados 60 dias pós-tratamento: PR, peso do rato; PC, peso da carcaça; PF, peso do fígado; PV, peso das vísceras; IVR, índice vísceras/peso rato; IHC, índice hepatocorporal; IHS, índice hepatossomático; * diferença estatística significante em relação ao $\mathrm{CT}, p<0,05$, teste $t$-Student

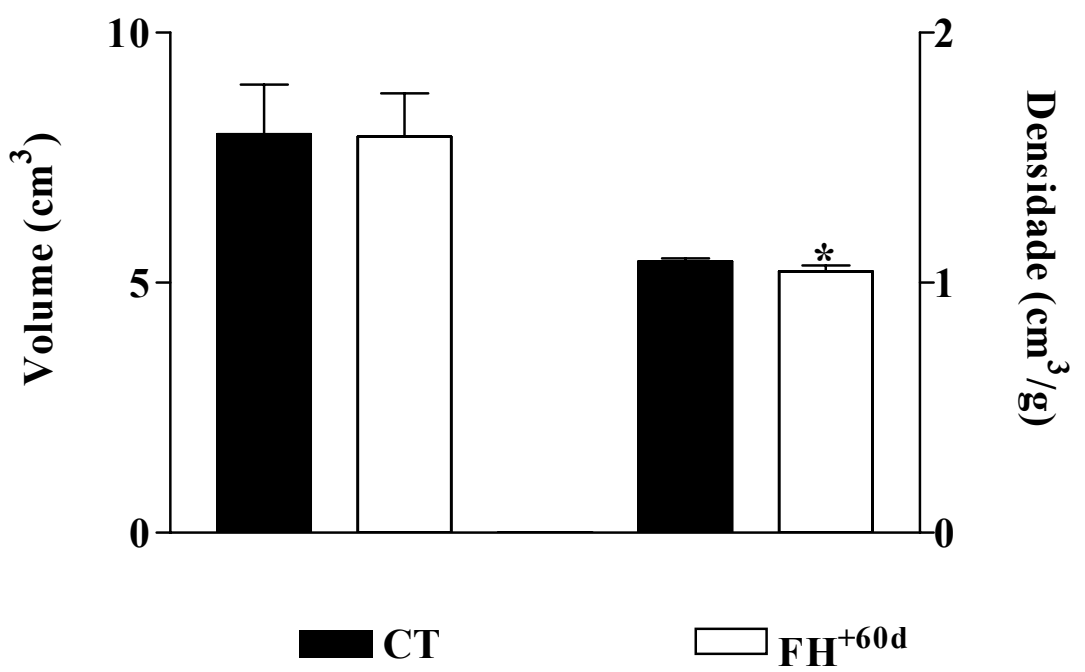

Gráfico 6 - Volume e densidade do fígado dos animais submetidos à indução da cirrose pela TAA, tratados $\left(\mathrm{FH}^{+60 d}\right)$ ou não $(\mathrm{CT})$ com os FHs por 12 dias e eutanasiados 60 dias póstratamento: * diferença estatística significante em relação ao $\mathrm{CT}, p<0,05$, teste $t$-Student 


\subsubsection{Os efeitos benéficos na função hepática se mantiveram pós-tratamento}

Os resultados da análise bioquímica realizada com o sangue obtido após a indução $\left(\mathrm{CS}_{1} \mathrm{~B}-\mathrm{CT}\right)$, após o tratamento com os FHs $\left(\mathrm{CS}_{1} \mathrm{~B}-\mathrm{FH}^{+60 \mathrm{~d}}\right)$ e na eutanásia $\left(\mathrm{CS}_{2} \mathrm{E}-\mathrm{CT}\right.$ e $\mathrm{CS}_{2} \mathrm{E}-$ $\mathrm{FH}^{+60 \mathrm{~d}}$ ) foram comparados inter e intragrupos gerando três comparações.

Na primeira comparação $\left(\mathrm{CS}_{2} \mathrm{E}-\mathrm{FH}^{+60 \mathrm{~d}}\right.$ vs. $\left.\mathrm{CS}_{1} \mathrm{E}-\mathrm{CT}\right)$ foram avaliados se os efeitos do tratamento com os FHs, 60 dias após o seu término, permaneceriam ou desapareceriam. Desta forma, os dados bioquímicos do sangue obtido na eutanásia dos grupos $\mathrm{CT}\left(\mathrm{CS}_{2} \mathrm{E}-\mathrm{CT}\right)$ e $\mathrm{FH}^{+60 \mathrm{~d}}\left(\mathrm{CS}_{2} \mathrm{E}-\mathrm{FH}^{+60 \mathrm{~d}}\right)$ foram comparados entre si. Os níveis de ALB, ALT e TBIL reduziram significantemente, e os índices de GGT e GLOB apresentaram aumento significante, os demais parâmetros não sofreram alterações (Tabela 7). Aparentemente alguns dos efeitos do tratamento com os FHs permaneceram 60 dias após o seu término.

A segunda comparação foi intragrupo $\left(\mathrm{CS}_{1} \mathrm{~B}-\mathrm{FH}^{+60 \mathrm{~d}}\right.$ vs. $\left.\mathrm{CS}_{2} \mathrm{E}-\mathrm{FH}^{+60 \mathrm{~d}}\right)$, e avaliou se os efeitos do tratamento com FHs observados imediatamente após o tratamento poderiam ser observados no $60^{\circ}$ dia pós-tratamento. Os níveis bioquímicos das enzimas ALKP, ALT e das proteínas GGT, TBIL e GLOB apresentaram redução estatisticamente significante em relação à análise realizada imediatamente após o final do tratamento (Tabela 7), indicando que os efeitos dos FHs sobre o desenvolvimento da cirrose não desapareceram com o final da sua administração.

$\mathrm{Na}$ terceira $\left(\mathrm{CS}_{1} \mathrm{~B}-\mathrm{CT}\right.$ vs. $\left.\mathrm{CS}_{2} \mathrm{E}-\mathrm{CT}\right)$ foi realizada uma nova comparação intragrupo, com a finalidade de observar as alterações que o quadro bioquímico da cirrose poderia sofrer no final do tempo experimental. Assim, foram comparados os dados obtidos com o sangue coletado na biópsia (imediatamente após a indução) e na eutanásia. O perfil bioquímico melhorou no final do tempo experimental $\left(\mathrm{CS}_{2} \mathrm{E}-\mathrm{CT}\right)$ em comparação ao observado logo após a indução $\left(\mathrm{CS}_{1} \mathrm{~B}-\mathrm{CT}\right)$, as proteínas ALB, TP e GLOB apresentaram aumento estatisticamente significante. Em adição, ALKP, AST e GGT reduziram significantemente em relação aos dados pós-indução (Tabela 7). 
Tabela 7 - Parâmetros da função bioquímica hepática do sangue coletado na biópsia e na eutanásia dos animais induzidos à cirrose pela administração da TAA e tratados $\left(\mathrm{FH}^{+60 d}\right)$ ou não $(\mathrm{CT})$ com os FHs por 12 dias e eutanasiados 60 dias pós-tratamento

\begin{tabular}{|c|c|c|c|c|}
\hline Parâmetros & $\mathrm{CS}_{1} \mathrm{~B}-\mathrm{CT}$ & $\mathrm{CS}_{1} \mathrm{~B}-\mathrm{FH}^{+60 \mathrm{~d}}$ & $\mathrm{CS}_{1} \mathrm{E}-\mathrm{CT}$ & $\mathrm{CS}_{2} \mathrm{E}-\mathrm{FH}^{+60 \mathrm{~d}}$ \\
\hline & $(n=13)$ & $(n=15)$ & $(n=13)$ & $(n=15)$ \\
\hline
\end{tabular}
$\operatorname{ALB}(g / d L)$
$2,10 \pm 0,24$
$2,31 \pm 0,35$
$2,92 \pm 0,27^{\mathbf{c}}$
$2,25 \pm 0,22^{a}$

$\operatorname{ALKP}(\mathbf{U} / \mathbf{L}) \quad 280,92 \pm 20,70 \quad 107,13 \pm 14,97 \quad 94,08 \pm 12,85^{\mathbf{c}} \quad 93,00 \pm 8,65^{\mathbf{b}}$
$\operatorname{ALT}(\mathbf{U} / \mathbf{L})$
$67,46 \pm 14,33$
$68,33 \pm 9,94$
$78,23 \pm 15,99$
$58,47 \pm 12,44^{\text {ab }}$

$\operatorname{AST}(\mathbf{U} / \mathbf{L}) \quad 194,85 \pm 17,59 \quad 109,13 \pm 13,92 \quad 120,92 \pm 24,44^{\mathbf{c}} \quad 120,13 \pm 12,26$

GGT (U/L) $\quad 5,60 \pm 0,93 \quad 0,50 \pm 0,61 \quad 0,15 \pm 0,26^{\mathbf{c}} \quad 0,39 \pm 0,72^{\text {ab }}$

TBIL (mg/dL)

$0,13 \pm 0,06$

$0,11 \pm 0,10$

$0,12 \pm 0,04$

$0,05 \pm 0,06^{\mathbf{a b}}$

TP (g/dL)

$5,41 \pm 0,32$

$6,86 \pm 0,64$

$6,85 \pm 0,30^{\mathbf{c}}$

$6,71 \pm 0,43$

GLOB (g/dL) $\quad 3,32 \pm 0,23 \quad 4,81 \pm 0,59 \quad 3,96 \pm 0,21^{\mathbf{c}} \quad 4,45 \pm 0,32^{\mathbf{a b}}$

$\overline{\mathbf{a}}$ diferença significante em relação a $\mathrm{CS}_{1} \mathrm{E}-\mathrm{CT} ;{ }^{\mathbf{b}}$ diferença significante em relação a $\mathrm{CS}_{1} \mathrm{~B}-\mathrm{FH}^{+60 \mathrm{~d}} \mathrm{e}^{\mathbf{c}}$ diferença significante em relação a $\mathrm{CS}_{1} \mathrm{~B}-\mathrm{CT} . p<0,05$, teste $t$-Student. ALB: albumina; ALKP: fosfatase alcalina; ALT: alanina aminotransferase; AST: aspartato aminotransferase; GGT: gama-glutamil transferase; TBIL: bilirrubina total; TP: proteína total; GLOB: globulina

Apesar da análise bioquímica mostrar que alguns dos efeitos do tratamento permaneceram após o seu término, nem todas as alterações celulares analisadas apresentaram diferenças significantes em relação aos animais tratados com os FHs.

A comparação intergrupos dos dados obtidos com a análise do tecido hepático colhido na eutanásia dos animais ( $\mathrm{CT}$ vs. $\mathrm{FH}^{+60 \mathrm{~d}}$ ) mostrou que o tratamento com os FHs aumentou significantemente a presença de células ovais, a vacuolização e reduziu a apoptose (Tabela 8 e Figura 25 A-B, E-F e G-H). Os demais parâmetros não mostraram alterações significantes. A comparação intragrupos, dos dados obtidos com a análise da biópsia e da eutanásia $\left(\mathrm{B}-\mathrm{FH}^{+60 \mathrm{~d}}\right.$ vs. $\mathrm{FH}^{+60 \mathrm{~d}}$ ), mostrou aumento significante na presença de inclusões eosinofílicas, indicando 
que estas alterações foram sensíveis ao final do tratamento. Os demais parâmetros não apresentaram diferenças significantes.

Tabela 8 - Alterações celulares hepáticas observadas na biópsia e na eutanásia dos animais induzidos à cirrose pela administração da TAA e tratados $\left(\mathrm{FH}^{+60 d}\right)$ ou não $(\mathrm{CT})$ com os $\mathrm{FHs}$ por 12 dias e eutanasiados 60 dias pós-tratamento

\begin{tabular}{|c|c|c|c|c|}
\hline Parâmetros & $\begin{array}{l}\text { B-CT } \\
(n=13)\end{array}$ & $\begin{array}{c}\text { CT } \\
(n=13)\end{array}$ & $\begin{array}{c}\text { B-FH }{ }^{+60 d} \\
(n=15)\end{array}$ & $\begin{array}{l}F^{+60 d} \\
(n=15)\end{array}$ \\
\hline Células ovais & $1,62 \pm 0,65$ & $1,50 \pm 0,52$ & $2,13 \pm 1,00$ & $2,20 \pm 0,70^{\mathbf{a}}$ \\
\hline Inclusões eosinofílicas & $1,31 \pm 0,50$ & $1,23 \pm 0,83$ & $1,90 \pm 1,13$ & $1,93 \pm 0,60^{\mathbf{a}}$ \\
\hline Figura mitótica & $1,10 \pm 0,50$ & $1,31 \pm 0,50$ & $1,30 \pm 0,80$ & $1,13 \pm 0,35$ \\
\hline Células binucleadas & $1,23 \pm 0,44$ & $1,54 \pm 0,70$ & $1,33 \pm 0,62$ & $1,90 \pm 0,52$ \\
\hline Esteatose & $0,15 \pm 0,40$ & $0,31 \pm 0,50$ & $0,13 \pm 0,52$ & $0,13 \pm 0,35$ \\
\hline Hemossiderina & $1,40 \pm 0,65$ & $1,70 \pm 0,85$ & $1,73 \pm 0,80$ & $2,33 \pm 0,82$ \\
\hline Megalocitose & $1,92 \pm 0,64$ & $1,54 \pm 0,52$ & $1,33 \pm 0,82$ & $1,60 \pm 0,74$ \\
\hline Vacuolização & $1,85 \pm 0,70$ & $1,62 \pm 0,90$ & $2,40 \pm 0,91$ & $2,30 \pm 0,70^{\mathbf{a}}$ \\
\hline Lesão nuclear & $1,70 \pm 0,50$ & $1,10 \pm 0,50^{\mathbf{c}}$ & $1,70 \pm 1,00$ & $1,33 \pm 0,50$ \\
\hline Corpúsculo apoptótico & $1,40 \pm 0,80$ & $1,10 \pm 0,50$ & $1,93 \pm 0,90$ & $1,13 \pm 0,52^{\mathbf{b}}$ \\
\hline
\end{tabular}

diferença significante em relação ao CT, $p<0,05$, teste de Mann-Whitney; ${ }^{\mathbf{b}}$ diferença significante em relação a $\mathrm{B}-\mathrm{FH}^{+60 \mathrm{~d}}, p<0,05$, teste de Wilcoxon $\mathrm{e}^{\mathbf{c}}$ diferença significante em relação a $\mathrm{B}-\mathrm{CT}, p<0,05$, teste de Wilcoxon 

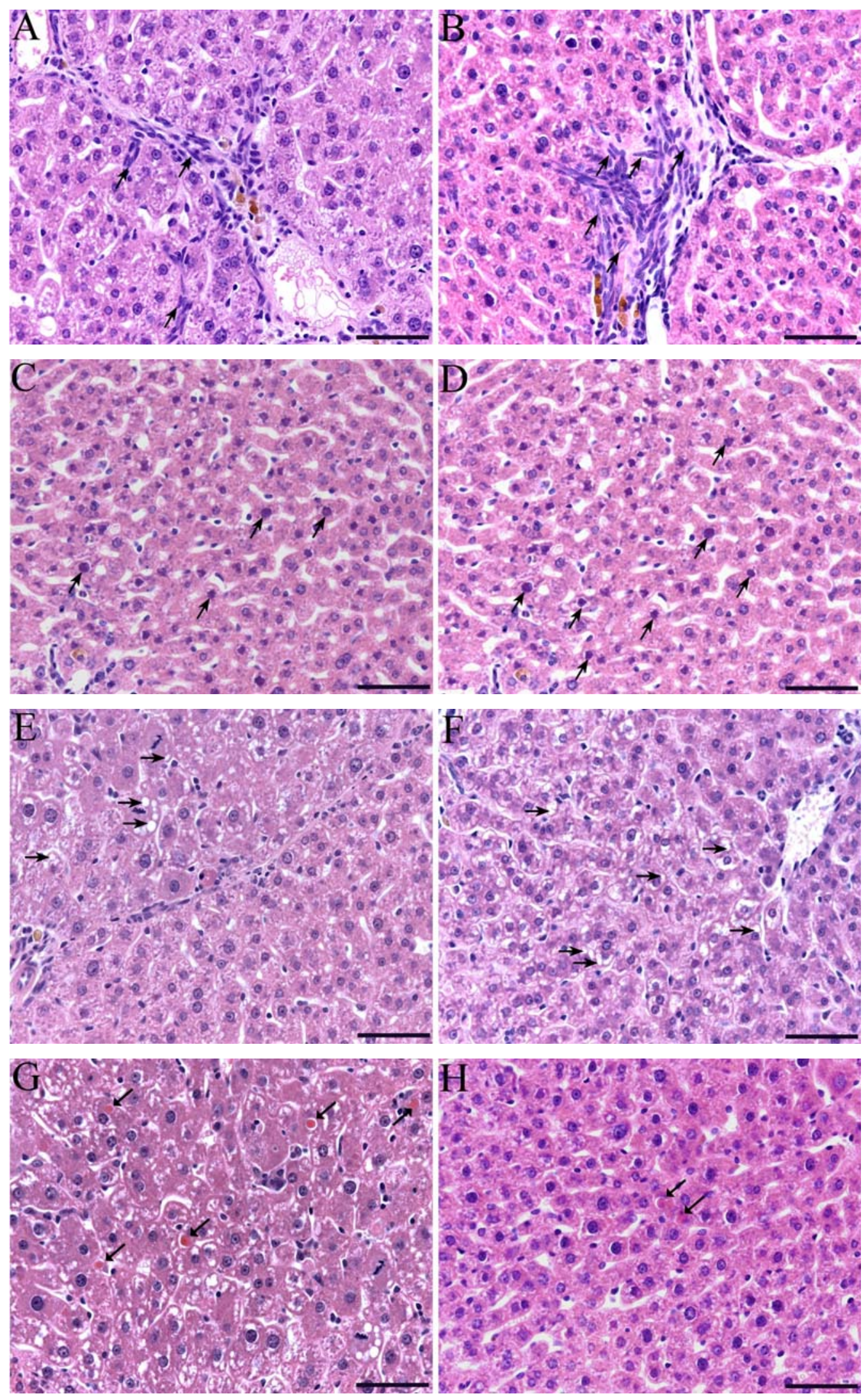

Figura 25 - Alterações celulares hepáticas (setas) observadas na eutanásia dos animais induzidos à cirrose pela administração da TAA e tratados $(\mathrm{FH})$ ou não $(\mathrm{CT}) \mathrm{com}$ os FHs por 12 dias e eutanasiados 60 dias pós-tratamento: células ovais, A) grupo CT e B) FH; inclusões eosinofílicas, C) grupo CT e D) FH; vacuolização, E) grupo CT e F) FH; corpúsculos apoptóticos, G) grupo CT e H) FH. Barra de escala $=50 \mu \mathrm{m}$ 


\subsubsection{A deposição de mucopolissacarídeos ácidos e de glicogênio aumentou 60 dias pós- tratamento}

A comparação intragrupo realizada no grupo CT, entre os dados obtidos com a biópsia (B-CT, 1 dia após a indução) e com a eutanásia (CT, no final do tempo experimental) mostrou que a deposição de mucopolissacarídeos ácidos aumentou durante o período experimental. A frequência da deposição moderada aumentou 300\% (de 7,69 para 30,77\%) e a intensa sofreu uma elevação de 0,00 para 15,38\% (Tabela 9). A comparação entre as biópsias dos grupos CT e $\mathrm{FH}^{+60 \mathrm{~d}}\left(\mathrm{~B}-\mathrm{CT}\right.$ vs. B-FH ${ }^{+60 \mathrm{~d}}$ ) mostrou que o tratamento com os $\mathrm{FHs}$ não alterou a evolução da deposição de mucopolissacarídeos ácidos, uma vez que todas as classificações apresentaram frequências muito semelhantes. A comparação dentro do grupo tratado com os FHs mostrou que o tratamento não evitou o aumento na deposição. A deposição moderada aumentou 300\% (de 6,67 para 26,67) e a intensa aumentou de 0,00 para 6,67\%. Entretanto, esta elevação foi menor em relação à apresentada pelos animais não tratados $\left(\mathrm{CT}\right.$ vs. $\left.\mathrm{FH}^{+60 \mathrm{~d}}\right)$. $\mathrm{O}$ grupo $\mathrm{FH}^{+60 \mathrm{~d}}$ apresentou redução nas deposições classificadas como moderada e intensa em comparação com o grupo CT. A classificação moderada reduziu em 13,32\% (de 30,77 para 26,67 ) e a intensa em $56,63 \%$ (de 15,38 para 6,67 ).

Conforme a tabela 9, a comparação intragrupo entre a biópsia e a eutanásia do grupo CT (B-CT vs. CT), mostrou que a deposição de glicogênio aumentou sua intensidade durante o tempo experimental. A deposição moderada aumentou em 250,13\% (de 15,38 para 53,85) e a intensa em 100,7\% (de 15,38 para 30,77). A comparação entre as biópsias dos grupos CT e $\mathrm{FH}^{+60 \mathrm{~d}}$ (B-CT vs. B-FH ${ }^{+60 d}$ ) mostrou que o tratamento reduziu a intensidade da deposição do glicogênio, reduzindo a classificação intensa de 15,38 para $0,00 \%$. Entretanto, esta redução não se manteve pós-tratamento, os dados obtidos com a eutanásia do grupo $\mathrm{FH}^{+60 \mathrm{~d}}\left(\mathrm{~B}-\mathrm{FH}^{+60 \mathrm{~d}}\right.$ vs. $\mathrm{FH}^{+60 d}$ ) mostraram que a deposição moderada sofreu um aumento de 233,35\% (de 20,00 para 66,67$)$ e a intensa se elevou de 0,00 para $26,67 \%$. Estes valores permaneceram muito próximos aos do grupo CT (respectivamente, 53,85 e 30,77\%). 
Tabela 9 - Frequência da deposição de mucopolissacarídeos ácidos e de glicogênio observada na biópsia e na eutanásia dos animais induzidos à cirrose pela administração da TAA e tratados $\left(\mathrm{FH}^{+60 d}\right)$ ou não (CT) com os FHs por 12 dias e eutanasiados 60 dias pós-tratamento

\begin{tabular}{|c|c|c|c|c|c|}
\hline \multirow[b]{2}{*}{ Parâmetros } & \multirow[b]{2}{*}{ Grupos (n) } & \multicolumn{4}{|c|}{ Frequência (\%) } \\
\hline & & Ausente & Pouca & Moderada & Intensa \\
\hline \multirow{4}{*}{$\begin{array}{c}\text { Presença de } \\
\text { Mucopolissacarídeos }\end{array}$} & B-CT (13) & 84,62 & 7,69 & 7,69 & 0,00 \\
\hline & CT (13) & 38,46 & 15,38 & 30,77 & 15,38 \\
\hline & B-FH ${ }^{+60 d}(15)$ & 86,67 & 6,67 & 6,67 & 0,00 \\
\hline & $\mathbf{F H}^{+60 d}(15)$ & 26,67 & 40,00 & 26,67 & 6,67 \\
\hline \multirow{4}{*}{$\begin{array}{l}\text { Acúmulo de } \\
\text { Glicogênio }\end{array}$} & B-CT (13) & 0,00 & 69,23 & 15,38 & 15,38 \\
\hline & CT (13) & 0,00 & 15,38 & 53,85 & 30,77 \\
\hline & B-FH ${ }^{+60 d}(15)$ & 0,00 & 80,00 & 20,00 & 0,00 \\
\hline & $\mathbf{F H}^{+60 d}(15)$ & 0,00 & 6,67 & 66,67 & 26,67 \\
\hline
\end{tabular}

\subsubsection{A atividade histológica e o estadiamento da fibrose/cirrose hepáticas não se alteraram pós-tratamento}

O índice de atividade histológica (IAH) obtido através da análise da atividade necroinflamatória classificada segundo os critérios de Knodell et al. (1981) e modificados por Ishak et al. (1995) demonstrou que a atividade histológica tecidual dos animais tratados não se 
alterou 60 dias pós-tratamento. A comparação dos dados, obtidos após análise do tecido hepático colhido na eutanásia, mostrou que as diferenças observadas entre os grupos CT $(6,41$ $\pm 1,32)$ e $\mathrm{FH}^{+60 \mathrm{~d}}(7,20 \pm 0,91)$ não foram estatisticamente significantes (Gráfico 7).

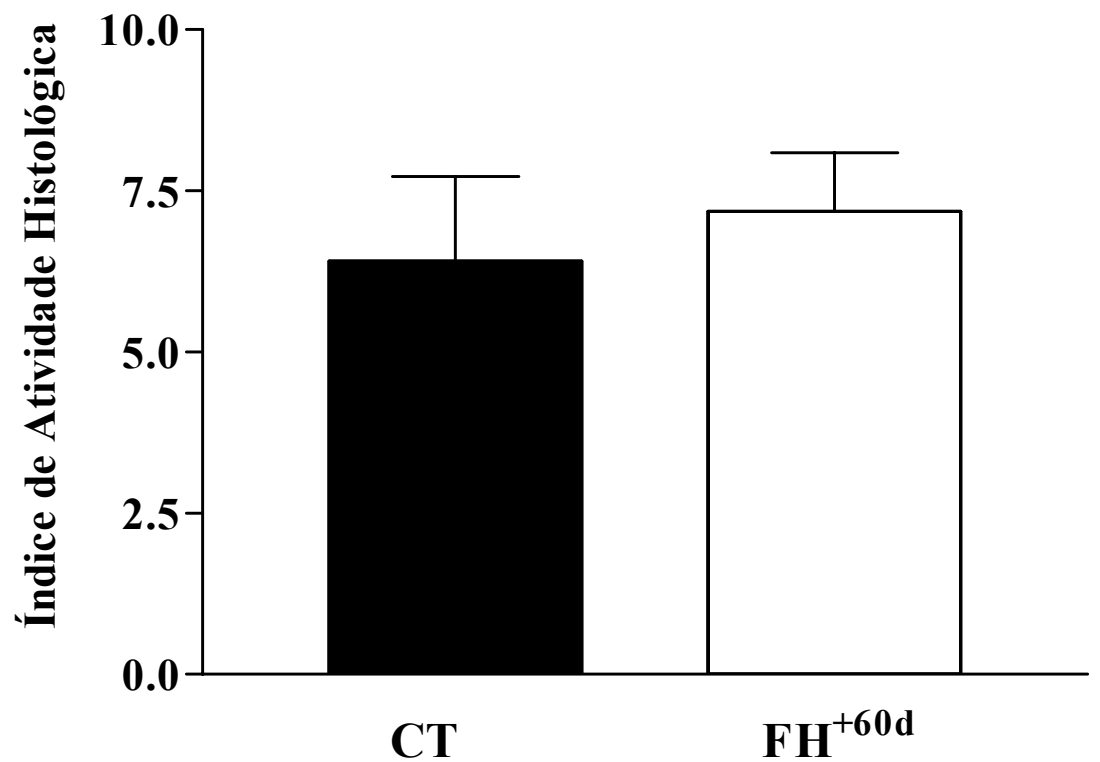

Gráfico 7 - Índice de atividade histológica obtido através da análise da atividade necro-inflamatória classificada segundo os critérios de Ishak et al. (1995) realizada no tecido hepático obtido na eutanásia dos animais induzidos à cirrose pela administração da TAA e tratados $\left(\mathrm{FH}^{+60 \mathrm{~d}}, \mathrm{n}=15\right)$ ou não $(\mathrm{CT}, \mathrm{n}=13)$ com os $\mathrm{FHs}$ por 12 dias e eutanasiados 60 dias pós-tratamento. Diferenças não significantes, $p>0,05$, teste de Mann-Whitney

A análise do estadiamento do grau da fibrose pelos critérios modificados por Ishak et al. (1995) realizada nos grupos submetidos à indução da cirrose e tratados $\left(\mathrm{FH}^{+60 \mathrm{~d}}, \mathrm{n}=15\right)$ ou não (CT, n=13) com os FHs e eutanasiados 60 dias pós-tratamento, não apresentou diferenças entre os grupos. A graduação nos grupos $\mathrm{CT}_{\text {e }} \mathrm{FH}^{+60 \mathrm{~d}}$ atingiu respectivamente, 4,70 $\pm 1,11 \mathrm{e}$ $5,13 \pm 0,91$; as diferenças observadas não foram significantes (Gráfico 8). 


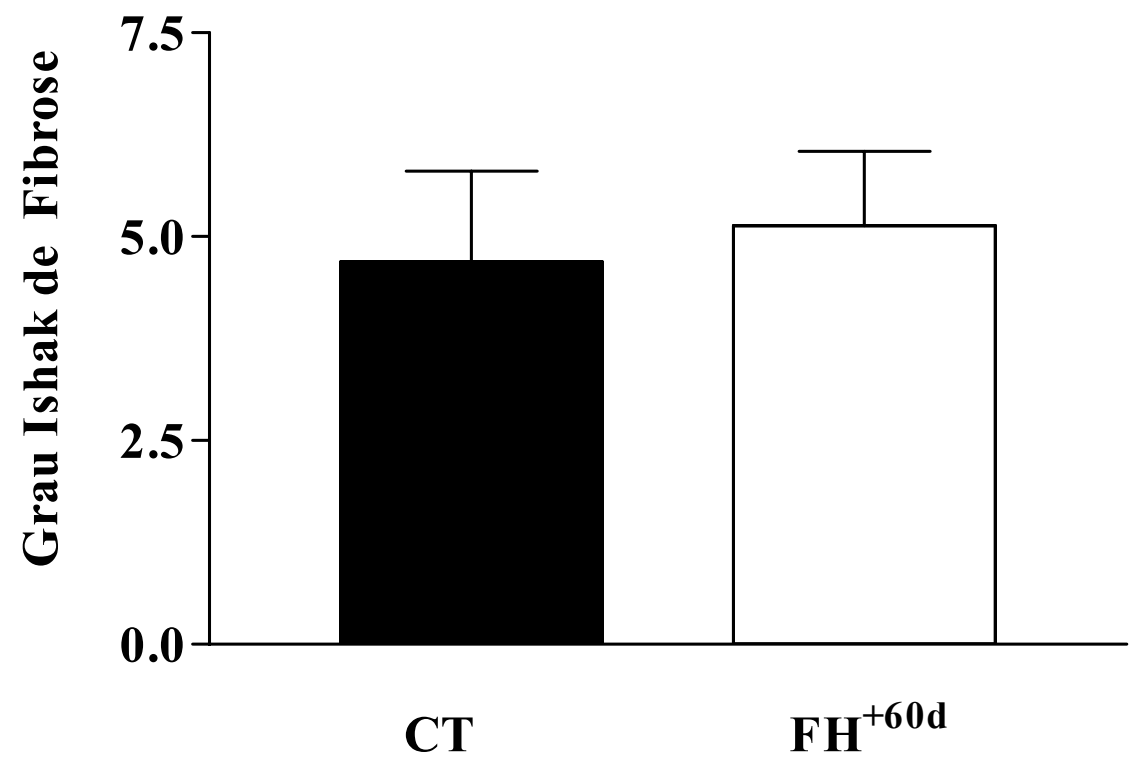

Gráfico 8 - Estadiamento da fibrose segundo os critérios de Ishak et al. (1995), no tecido hepático obtido na eutanásia dos animais induzidos à cirrose pela administração da TAA e tratados $\left(\mathrm{FH}^{+60 \mathrm{~d}}, \mathrm{n}=15\right)$ ou não $(\mathrm{CT}, \mathrm{n}=13)$ com os $\mathrm{FHs}$ por 12 dias e eutanasiados 60 dias pós-tratamento. Diferenças não significantes, $p>0,05$, teste de Mann-Whitney

\subsubsection{A proliferação dos ductos hepáticos não sofreu alteração pós-tratamento}

A comparação intragrupos (B-CT vs. CT) mostrou que a proliferação dos ductos aumentou ao longo do tempo experimental (de $0,23 \pm 0,60$ para $1,61 \pm 1,19$ ). Por outo lado, a comparação entre os dados obtidos com a biópsia dos grupos CT e $\mathrm{FH}^{+60 \mathrm{~d}}$ (B-CT vs. B$\mathrm{FH}^{+60 \mathrm{~d}}$ ) mostrou redução significante na proliferação, diminuindo os escores respectivamente, de $0,23 \pm 0,60$ para $0,13 \pm 0,35$. Entretanto, quando foi realizada a comparação intragrupos $\left(\mathrm{B}-\mathrm{FH}^{+60 \mathrm{~d}}\right.$ vs. $\left.\mathrm{FH}^{+60 \mathrm{~d}}\right)$ pode-se observar que a proliferação voltou a aumentar, o escore de B-

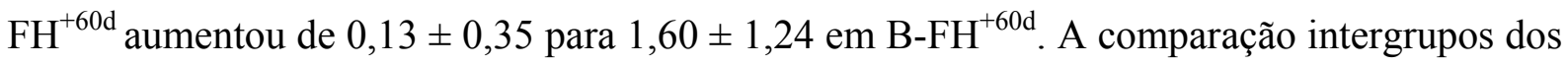
dados da eutanásia $\left(\mathrm{FH}^{+60 \mathrm{~d}}\right.$ vs. $\mathrm{CT}$ ) comprovou que os efeitos da administração dos $\mathrm{FHs}$ não permaneceram após o final do tratamento, os grupos $\mathrm{FH}^{+60 \mathrm{~d}}$ e $\mathrm{CT}$ mostraram escores iguais de $1,61 \pm 1,20$ (Gráfico 9). 


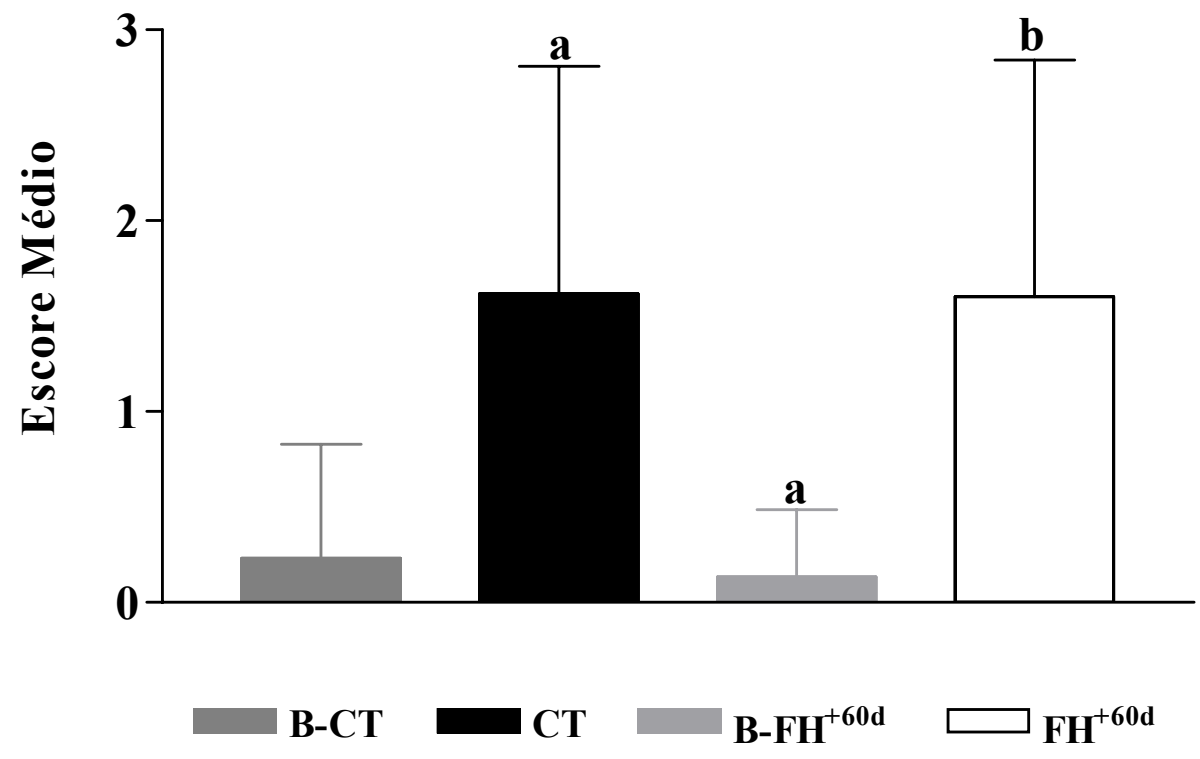

Gráfico 9 - Proliferação de ductos observada na biópsia e na eutanásia do tecido hepático dos animais induzidos à cirrose pela administração da TAA e tratados $\left(\mathrm{FH}^{+60 \mathrm{~d}}, \mathrm{n}=15\right)$ ou não $(\mathrm{CT}, \mathrm{n}=13)$ com os $\mathrm{FHs}$ por 12 dias e eutanasiados 60 dias pós-tratamento. ${ }^{a}$ diferença significante em relação a B-CT, $p<0,05$, teste $t$-Student; ${ }^{\mathrm{b}}$ diferença significante em relação a $\mathrm{B}-\mathrm{FH}^{+60 \mathrm{~d}}, p<0,05$, teste de Mann-Whitney

\subsubsection{Os efeitos do tratamento sobre a deposição do colágeno intralobular permaneceram 60 dias após o seu término}

A comparação intragrupo, realizada com os dados do grupo CT (B-CT vs. CT), mostrou que o colágeno interlobular diminuiu e o intralobular aumentou ao longo de todo o período experimental. Por outro lado, a mesma comparação $\left(\mathrm{B}-\mathrm{FH}^{+60 \mathrm{~d}}\right.$ vs. $\mathrm{FH}^{+60 \mathrm{~d}}$ ) realizada no grupo $\mathrm{FH}^{+60 \mathrm{~d}}$, não mostrou diferenças significantes entre os colágenos inter e intralobular. Entretanto, indicou que a deposição de colágeno, apesar do término do tratamento não aumentou. Em adição, quando os dados do tecido hepático do grupo $\mathrm{FH}^{+60 \mathrm{~d}}$, colhido no momento da eutanásia $\left(\mathrm{FH}^{+60 \mathrm{~d}}\right)$, foram confrontados com o do $\mathrm{CT}$, observou-se redução significante de $56 \%$ na proporção volumétrica do colágeno intralobular, indicando que os 
efeitos dos FHs permaneceram mesmo após o final do tratamento (Tabela 10 e Figura 26 AC).

Tabela 10 - Proporção volumétrica do colágeno inter e intralobular no tecido hepático obtido na biópsia e na eutanásia dos animais induzidos à cirrose pela administração da TAA e tratados $\left(\mathrm{FH}^{+60 d}\right)$ ou não $(\mathrm{CT})$ com os $\mathrm{FHs}$ por 12 dias e eutanasiados 60 dias póstratamento

\begin{tabular}{ccccc}
\hline Tipo de Colágeno & B-CT & $\mathbf{C T}$ & $\mathbf{B}-\mathbf{F H}^{+\mathbf{6 0 d}}$ & $\mathbf{F H}^{+\mathbf{6 0 d}}$ \\
& $(\mathbf{n}=\mathbf{1 3})$ & $(\mathbf{n}=\mathbf{1 3})$ & $\mathbf{( n = 1 5 )}$ & $\mathbf{( n = 1 5 )}$ \\
\hline Interlobular & $5,20 \pm 2,31$ & $4,00 \pm 1,31^{\mathbf{b}}$ & $4,95 \pm 1,96$ & $5,14 \pm 1,55$ \\
Intralobular & $0,22 \pm 0,07$ & $0,34 \pm 0,08^{\mathbf{b}}$ & $0,20 \pm 0,06$ & $0,15 \pm 0,06^{\mathbf{a}}$ \\
\hline
\end{tabular}

${ }^{a}$ diferença significante em relação ao $\mathrm{CT} ;{ }^{\mathbf{b}}$ diferença significante em relação ao B-CT $p<0,05$, teste t-Student 

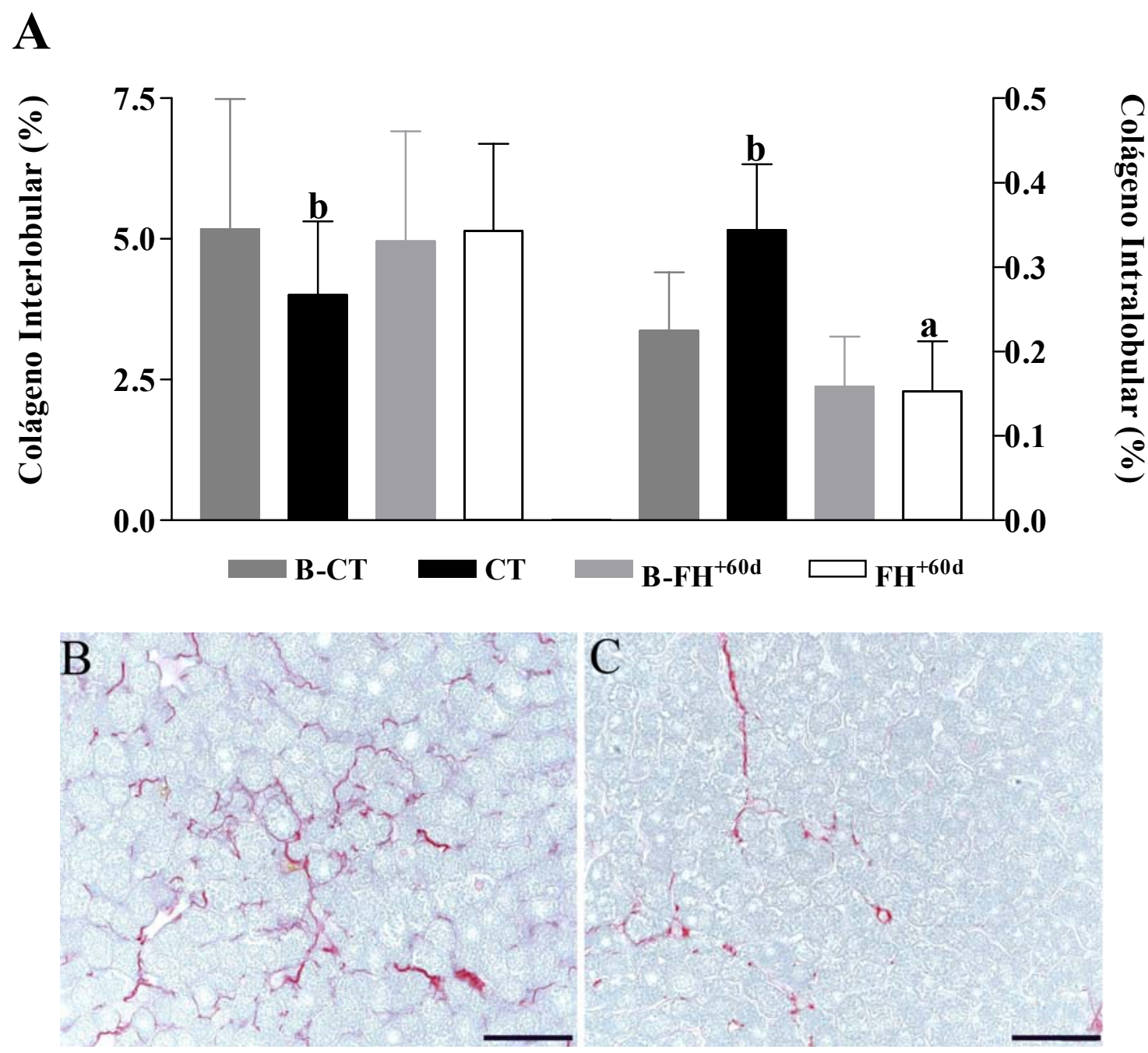

Figura 26 - A) Proporção volumétrica da área ocupada pelos colágenos inter e intralobulares no tecido hepático obtidos na biópsia e na eutanásia dos animais induzidos à cirrose pela administração da TAA e tratados $\left(\mathrm{FH}^{+60 \mathrm{~d}}, \mathrm{n}=15\right)$ ou não $(\mathrm{CT}, \mathrm{n}=13)$ com os $\mathrm{FHs}$ por 12 dias e eutanasiados 60 dias pós-tratamento. ${ }^{\mathbf{a}}$ diferença significante em relação ao CT; ${ }^{\mathbf{b}}$ diferença significante em relação ao B-CT $p<0,05$, teste $t$-Student. Destaque da redução do colágeno intralobular: B) grupo $\mathrm{CT}$ e C) $\mathrm{FH}^{+60 \mathrm{~d}}$, coloração picrossírius. Barra de escala $=50 \mu \mathrm{m}$

A figura 27 A-B apresenta a marcação por imunofluorescência dos colágenos tipo 1 (Figura 27 A) e 3 (Figura 27 C) no tecido hepático obtido na eutanásia dos animais. As fotos são apenas ilustrativas, não houve quantificação dos diferentes tipos, mas, no grupo $\mathrm{FH}^{+60 \mathrm{~d}}$ (Figura 27 B) é possível observar a maior concentração do colágeno intralobular, em relação ao CT (Figura 27 A). A figura evidencia também, que a predominância do colágeno tipo 1 (Figuar 27 A) em relação ao tipo 3 (Figura 27 C) permaneceu 60 dias pós-tratamento. 

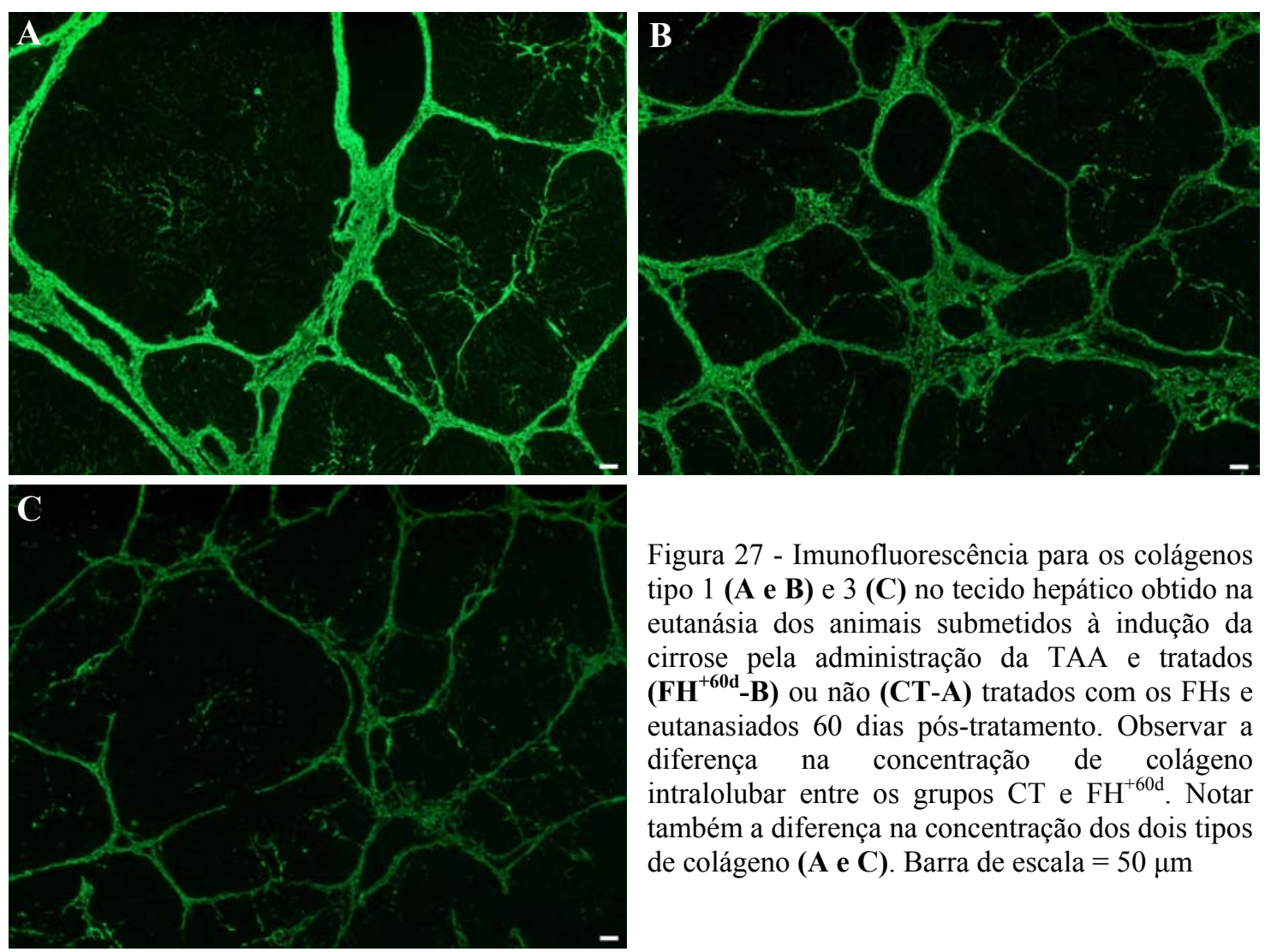

Figura 27 - Imunofluorescência para os colágenos tipo 1 (A e B) e 3 (C) no tecido hepático obtido na eutanásia dos animais submetidos à indução da cirrose pela administração da TAA e tratados $\left(\mathbf{F H}^{+60 d}\right.$-B) ou não (CT-A) tratados com os FHs e eutanasiados 60 dias pós-tratamento. Observar a diferença na concentração de colágeno intralolubar entre os grupos $\mathrm{CT}$ e $\mathrm{FH}^{+60 \mathrm{~d}}$. Notar também a diferença na concentração dos dois tipos de colágeno (A e C). Barra de escala $=50 \mu \mathrm{m}$

\subsubsection{A ativação das células estreladas aumentou pós-tratamento}

A quantificação das células positivas para a imunomarcação da $\alpha$-SMA, realizada no tecido hepático obtido na eutanásia dos animais, mostrou que o grupo tratado com os FHs $\left(\mathrm{FH}^{+60 \mathrm{~d}}\right)$ apresentou aumento significante de $79,97 \%(1,81 \pm 1,40)$, em comparação ao grupo CT $(1,01 \pm 0,40)$, conforme pode ser observado na figura $28 \mathrm{~A}-\mathrm{C}$. 
A
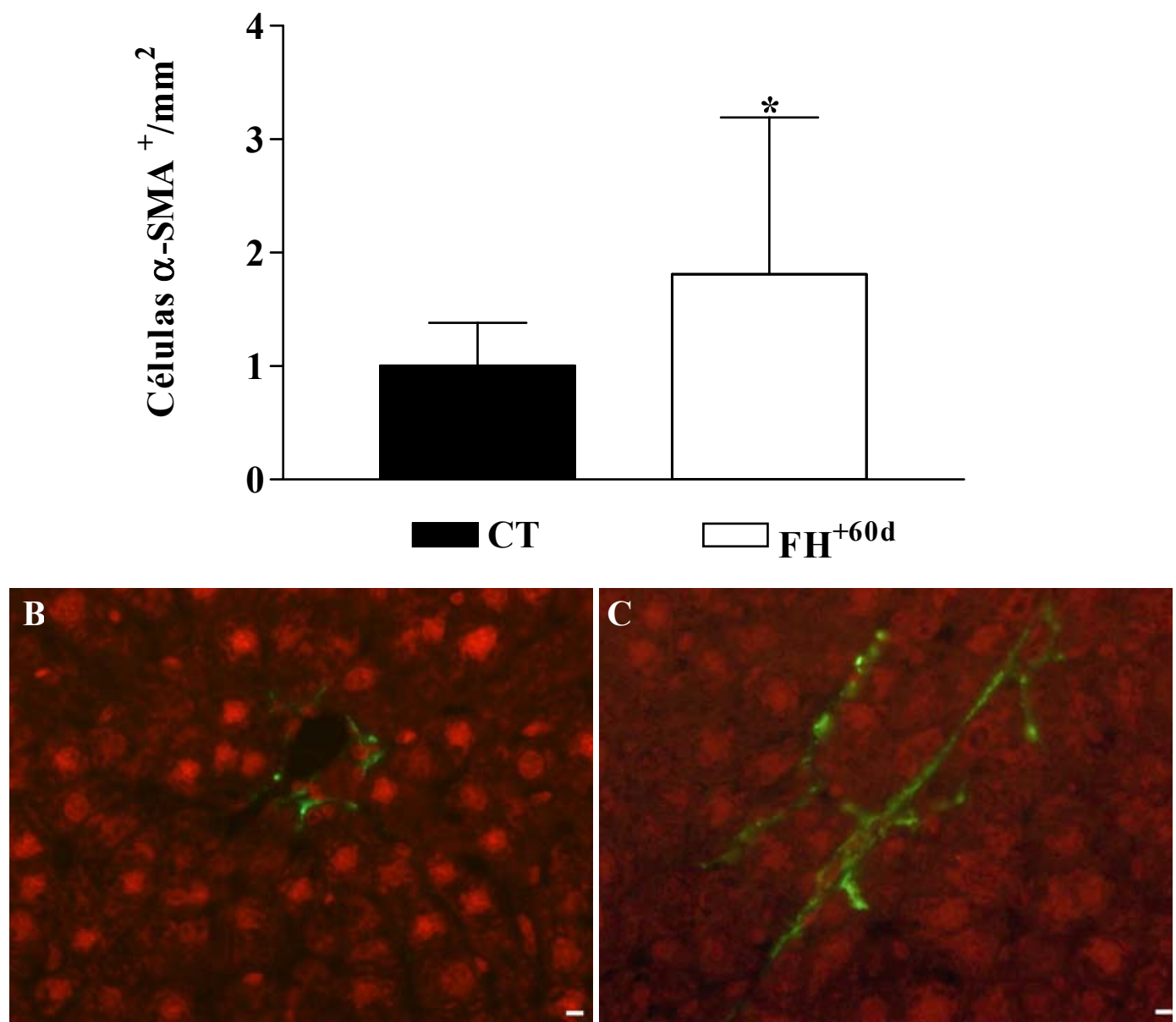

Figura 28 - Análise da imunomarcação das células positivas para $\alpha$-SMA realizada no tecido hepático obtido na eutanásia dos animais submetidos à indução da cirrose pela TAA e tratados $\left(\mathrm{FH}^{+60 d}\right)$ ou não $(\mathrm{CT})$ com os $\mathrm{FHs}$ por 12 dias e eutanasiados 60 dias póstratamento. A) quantificação das células $\alpha-\mathrm{SMA}^{+}$por $\mathrm{mm}^{2}$ de tecido. * diferença significante em relação ao CT, $p<0,05$, teste de Mann-Whitney. B) imunofluorescência evidenciando marcação no grupo CT e em C) no grupo $\mathrm{FH}^{+60 \mathrm{~d}}$. Contra-coloração nuclear com iodeto de propídeo. Barra de escala $=5 \mu \mathrm{m}$

\subsubsection{A proliferação dos hepatócitos reduziu após o tratamento com os FHs}

A análise dos efeitos sobre a proliferação dos hepatócitos pela imunomarcação do PCNA (Figura 29 A-C), realizada no tecido hepático obtido na eutanásia dos animais dos grupos $\mathrm{CT}$ e $\mathrm{FH}^{+60 \mathrm{~d}}$, mostrou que a proliferação dos hepatócitos reduziu 60 dias pós-

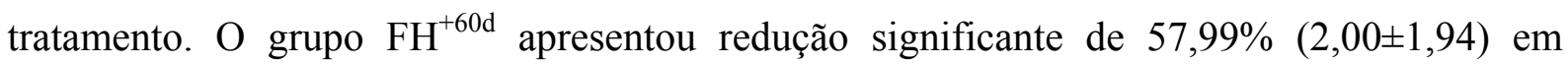
relação ao grupo CT $(4,77 \pm 3,20)$. 
A
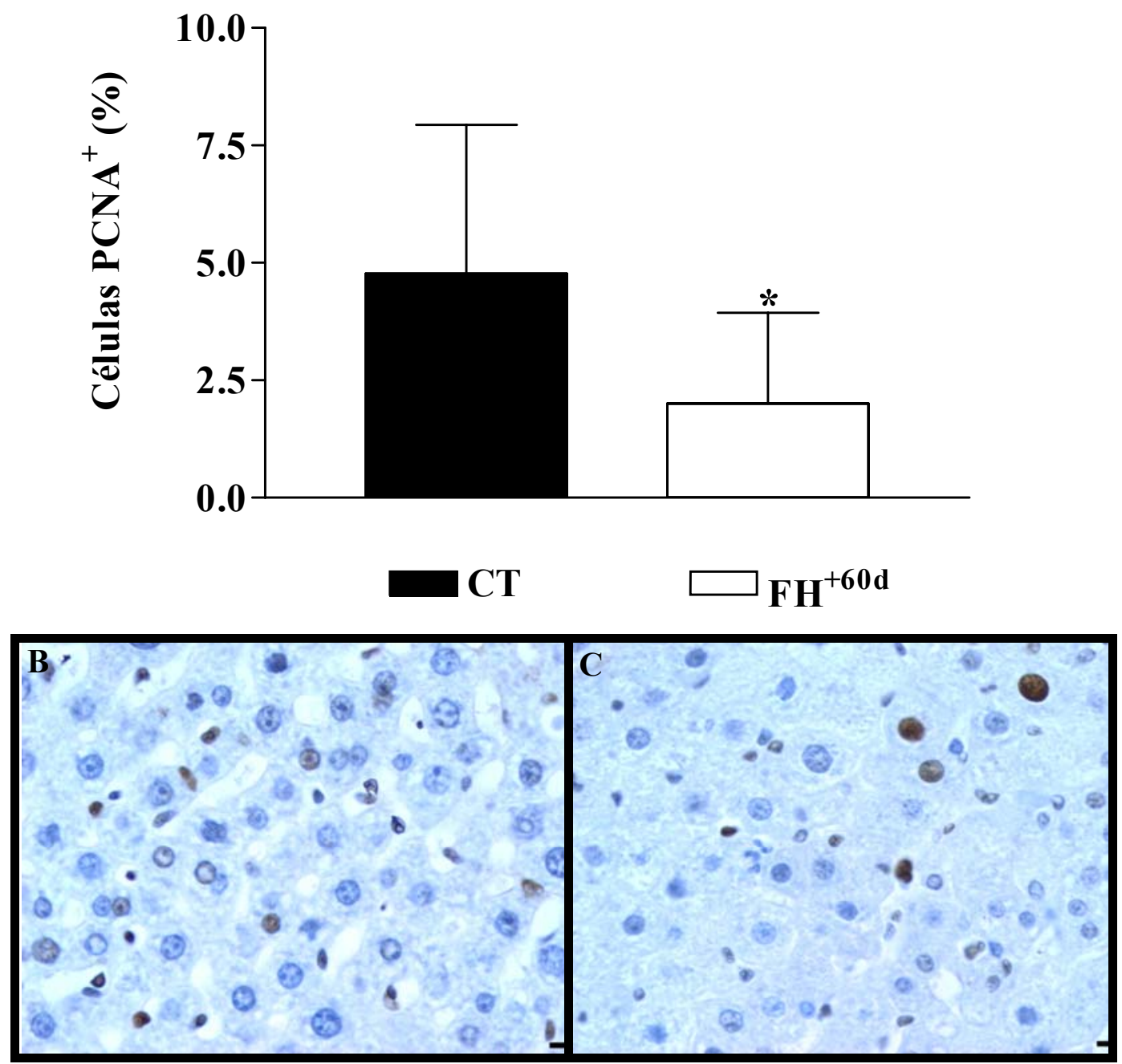

Figura 29 - A) Análise da imunomarcação das células positivas para PCNA realizada no tecido hepático obtido na eutanásia dos animais submetidos à indução da cirrose pela TAA e tratados $\left(\mathrm{FH}^{+60 d}\right)$ ou não $(\mathrm{CT})$ com os $\mathrm{FHs}$ por 12 dias e eutanasiados 60 dias após o tratamento. * diferença significante em relação ao CT, $p<0,05$, teste de MannWhitney. B) grupo $\mathrm{CT}$ e C) grupo $\mathrm{FH}^{+60 d}$. Barra de escala $=5 \mu \mathrm{m}$

\subsubsection{Os mecanismos de fibrólise permaneceram alterados 60 dias após o término do tratamento}

A figura 30 A-F mostra a avaliação da expressão dos principais genes envolvidos na fibrogênese hepática, dos animais submetidos à indução da cirrose pela TAA e tratados 
$\left(\mathrm{FH}^{+60 \mathrm{~d}}\right)$ ou não $(\mathrm{CT})$ com os $\mathrm{FHs}$ e eutanasiados 60 dias pós-tratamento, realizada por PCR em tempo real. Os efeitos do tratamento sobre a fibrólise hepática permaneceram póstratamento. A expressão gênica dos genes MMP-13, responsável pela degradação dos colágenos tipo 1 e 3, e do PLAU, ativador indireto das MMPs (Figura 30 E e F), no grupo $\mathrm{FH}^{+60 \mathrm{~d}}$ (respectivamente 2,51 $\pm 0,93$ e 2,84 $\pm 0,74$ ) apresentou aumento significante em relação ao grupo CT (respectivamente $1,00 \pm 0,48$ e 1,00 \pm 0,78). Entretanto, apesar do aumento na expressão de genes envolvidos na degradação de componentes da matriz extracelular, a expressão do colágeno tipo 1 (Figura $30 \mathrm{~A}$ ) no grupo $\mathrm{FH}^{+60 \mathrm{~d}}(5,34 \pm 1,70)$ mostrou significante aumento em relação ao grupo CT $(1,00 \pm 0,75)$. As diferenças na expressão dos demais genes não foram significantes. 
Colágeno tipo 1

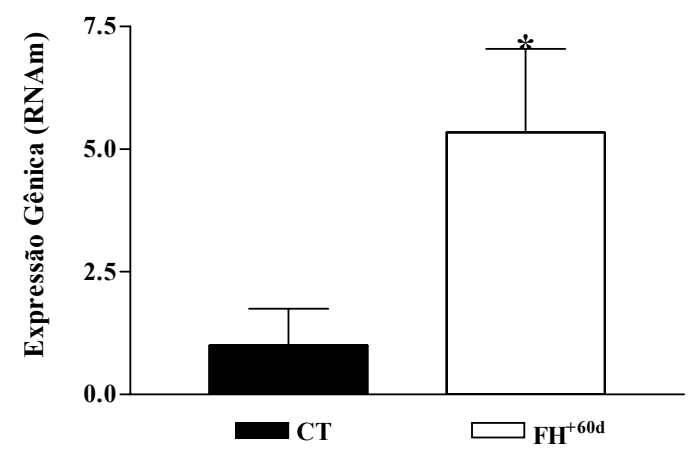

TIMP-1

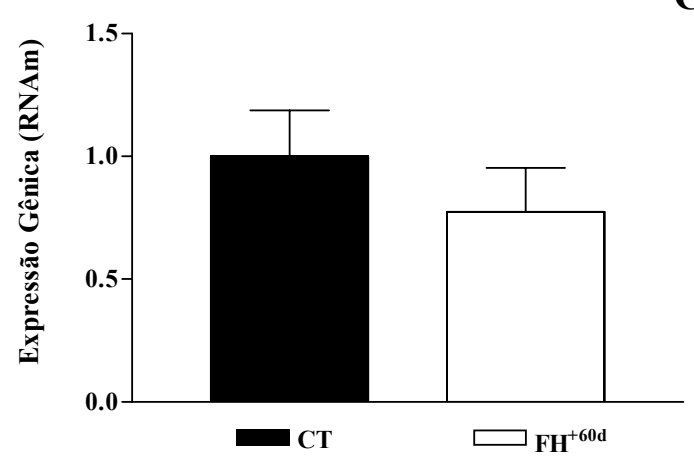

MMP-13

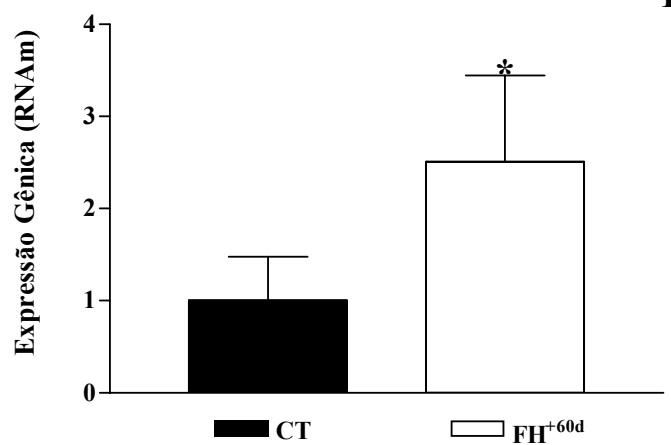

A
TGF $\beta-1$

B

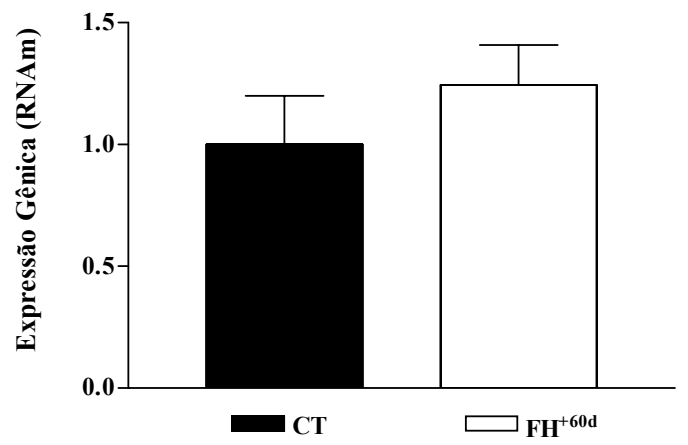

C

MMP-2

D

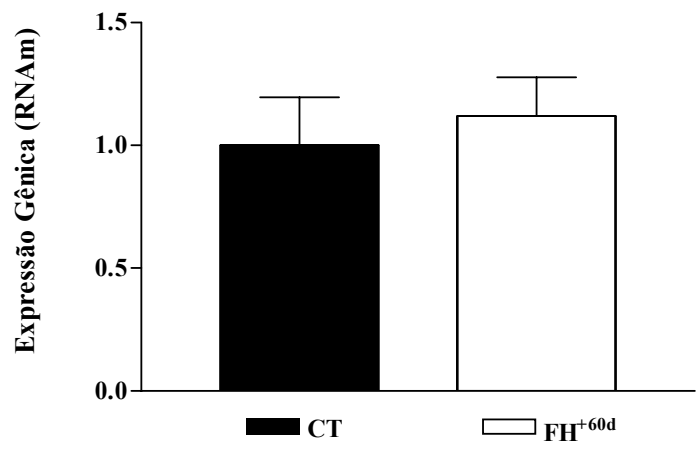

$\mathbf{E}$

PLAU

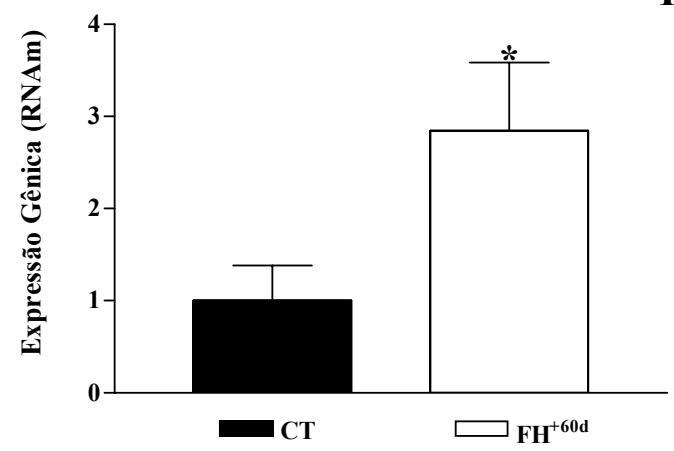

Figura 30 - Expressão relativa dos principais genes envolvidos na fibrogênese hepática obtida pela análise do fígado dos animais submetidos à indução da cirrose pela TAA e tratados $\left(\mathrm{FH}^{+60 \mathrm{~d}}\right)$ ou não $(\mathrm{CT})$ com os $\mathrm{FHs}$ por 12 dias e eutanasiados 60 dias pós-tratamento. A) Colágeno tipo 1; B) TGF $\beta-1$; C) TIMP-1; D) MMP-2; E) MMP-13 e F) PLAU. * diferença significante em relação ao CT, $p<0,05$, teste de Mann-Whitney 


\section{DISCUSSÃO}

O índice de mortalidade de pacientes com cirrose hepática em 35 países da Europa Central e Oriental é de 100.000 pessoas/ano nas idades de 20-64 anos (ZATOŃSKI et al., 2010). Um estudo realizado em 1997 em todas as regiões do Brasil indicou que, 12.363 mortes em adultos foram causadas pela cirrose hepática, 9.937 (80,4\%) em homens e 2.426 $(19,6 \%)$ em mulheres. Mais de três quartos $(75,4 \%)$ dos óbitos masculinos ocorreu entre idades de 20 e 59 anos, em comparação com 61,8\% dos óbitos do sexo feminino (LESSA, 1997).

Geralmente a cirrose é irreversível, e é incerto se a distorção arquitetural e os desarranjos vasculares na cirrose avançada podem retornar a uma estrutura normal, contudo, uma resolução incompleta, mas não total da cirrose micronodular pode ser observada em animais experimentais (GARCIA-BAÑUELOS et al., 2002; DESMET, ROSKAMS, 2004; KUMAR; SARIN, 2007; SATO et al., 2008, SOBREVALS et al., 2010). O tratamento para a cirrose está focado na progressiva prevenção de complicações, portanto, pode ter sua evolução desacelerada ou mesmo revertida, como, por exemplo, com a utilização dos fatores hepatotróficos (FHs) (GUERRA et al., 2009; COGLIATI et al., 2010).

De forma geral, nesta pesquisa, os FHs melhoraram os níveis de função hepática após o término do tratamento, e alguns destes índices se mantiveram depois de 60 dias; apesar do grau de atividade histológica e do estadiamento das lesões hepáticas não se alterarem com o tratamento, foi observado diminuição na deposição do colágeno interlobular com os FHs, e depois de 60 dias houve diminuição do colágeno intralobular; o número de células estreladas hepáticas diminuiu com o tratamento, em contrapartida o índice de proliferação celular não se alterou a curto prazo; o contrário foi observado depois de 60 dias, as células estreladas hepáticas aumentaram e o índice de proliferação celular diminuiu. A expressão do colágeno tipo I reduziu de forma significativa com o tratamento a curto prazo, porém aumentou após 60 dias, por outro lado, a expressão da TIMP-1, MMP-13 e PLAU, aumentaram, após final do tratamento; somente MMP-13 e PLAU aumentaram a longo prazo.

Abaixo, segue a discussão dos resultados em separado, sobre os efeitos dos FHs na cirrose hepática experimental induzida pela TAA, imediatamente após tratamento e depois de 60 (sessenta) dias. 


\subsection{DISCUSSÃO DOS RESULTADOS OBSERVADOS IMEDIATAMENTE APÓS TRATAMENTO COM OS FATORES HEPATOTRÓFICOS - GRUPO FH E SEU CONTROLE (CT)}

Durante as 14 semanas de indução da cirrose pela TAA alguns animais apresentaram flacidez da pele, posição álgica, diarréia, alopecia, secreção porfirinêmica da glândula de Harder em torno dos olhos, piloereção e amarelamento da pelagem. O grupo FH submetido ao tratamento com os FHs mostrou posição álgica e piloereção. A manifestação destes sintomas, aparentemente, estava diretamente relacionada ao estresse dos tratamentos (TAA e FHs). O amarelamento da pelagem, assim como no caso da pele da espécie humana, está associado à icterícia causada pela cirrose quando acomete o sistema biliar; já a secreção porfirinêmica em torno dos olhos, é proveniente da excessiva secreção de porfirinas pela glândula de Harder, que se acumula nos olhos e no nariz do animal. Sua manifestação, conhecida como cromodacriorréia, ocorre em situações de estresse induzido por dor ou doença e é relatada em quadros de inflamação. A presença dessa secreção tem sido utilizada como indicador de doenças crônicas em animais de laboratório (BRISTOW; YOUNG, 1994; HARPER et al., 2001).

O grupo FH apresentou 13,33\% de mortalidade, correspondente à morte de dois animais, um foi a óbito ao final do período de indução da cirrose, e o outro no momento da execução da biópsia hepática. Um dos efeitos colaterais da cirrose é a perda do apetite, e ambos os animais apresentavam baixo peso corporal, principalmente ao que foi a óbito no momento da biópsia. Lima (2008) encontrou um índice de mortalidade de 5\% em 20 animais induzidos à cirrose por injeções intraperitoneais de TAA por 14 semanas, e quando a dose da droga foi aumentada em 10 e 15\% a cada 25 dias ao longo das 14 semanas, o óbito, respectivamente foi de 14,3\% em 35 animais e 44\% em 25 animais. Alóia et al. (2010) observaram índice de mortalidade de 26,7\% em ratas sadias tratadas com FHs por 10 dias em três injeções intraperitoneais diárias.

$\mathrm{O}$ animal do grupo FH foi a óbito pelas condições físicas apresentadas durante a realização da biópsia hepática, não sendo propriamente a execução desta, a causa mortis. Durante a execução das biópsias, não foi observado nenhum óbito, e uma rápida recuperação dos animais também foi notada. Com esta técnica foi possível analisar e concluir que os 
fragmentos coletados dos animais que compunham os grupos experimentais estavam com quadro de cirrose pela administração da TAA.

A biópsia hepática é o "gold standard" para se avaliar a histologia hepática em pacientes que apresentam injúrias crônicas, porém é altamente invasiva; em humanos a biópsia hepática leva aos riscos de complicações com morbidade entre $0,3 \%$ e $0,6 \%$; e mortalidade de 0,05\% (CADRANEL et al., 2000; BOURLIERE et al., 2006).

Nesta pesquisa a biópsia foi importante para confirmar o resultado da indução da cirrose pela TAA, assim como outros relatos em modelos de ratos submetidos à biópsia hepática (FRASER et al., 1989; ABDEL-AZIZ et al., 1990; ARTHUR, 1990; ZIMMERMAN et al., 1992; ROSEMBAUM, BLAZEJEWESKI, 1995; IREDALE et al., 1998; FRIEDMAN, 1999).

A evolução do peso corporal médio dos animais submetidos ao modelo de indução pela TAA e tratados (FH) com os FHs por 12 dias apresentou um comportamento linear constante, mas a partir do final da indução, 14 a semana, o peso dos animais do grupo FH apresentou redução significante, retornando nas últimas duas semanas em comparação ao grupo CT. O grupo FH também teve redução significativa no índice vísceras/peso corporal, aumento na densidade do fígado e no peso da carcaça.

A diminuição no peso e no índice vísceras/peso corporal final provavelmente ocorreu pelo estresse manipulativo porque o grupo $\mathrm{FH}$, após o término da indução da cirrose foi submetido à biópsia hepática, seguido do início do tratamento com os FHs. Um aumento no peso corporal foi observado por Guerra et al. (2009) em animais submetidos às mesmas condições experimentais desta pesquisa, diferindo apenas no tratamento com os FHs que foi de 10 dias.

Mesmo com a diminuição observada no peso dos animais tratados com os FHs, houve um aumento significante na densidade do fígado e no peso da carcaça no grupo $\mathrm{FH}$, este aumento pode ter sido ocasionado pela solução de FHs, que além de ser rica em nutrientes, é acrescida de fatores hormonais. Cogliati et al. (2010) não observaram alterações na densidade do fígado em ratas induzidas à fibrose hepática pela dimetilnitrosamina e tratados com FHs por 10 dias. Outro fator, para a diminuição do peso observado no grupo FH seria a administração crônica da TAA. A administração prolongada desta hepatotoxina provoca perda de peso (MOREIRA et al., 1995; FONTANA et al., 1996; AL-BADER et al., 2000; JEONG et al., 2001). 
Os resultados obtidos nesta pesquisa em relação ao índice vísceras/peso corporal e a densidade do fígado não foram notados por Alóia et al. (2010) em ratas sadias, pois o tratamento com os FHs por 10 dias em duas injeções intraperitoneais diárias aumentou o índice vísceras/peso corporal, diminuiu a densidade do fígado se comparado ao controle, contudo o peso da carcaça aumentou, resultado semelhante ao observado neste experimento.

O uso de substâncias tróficas hepáticas é uma suposição de que o tamanho do fígado é regulado pela quantidade de sangue que chega através da veia porta e pela concentração dos componentes do sangue portal, informação sugerida para explicar o crescimento do fígado em transplantes hepáticos de tamanho pequeno (KAM et al., 1987; van THIEL et al., 1987; FRANCAVILLA et al., 1994; IKEGAMI et al., 2008). O contrário é observado quando a concentração dos componentes do sangue portal é reduzida pela má nutrição, e há acentuada diminuição no tamanho do fígado (PARRA et al., 1995a).

Os indicadores bioquímicos de lesão hepática têm a função de averiguar o estado geral do fígado e sistema biliar (GOMES et al., 2008). O tratamento com os FHs reduziu significantemente os índices de ALKP, ALT, AST, GGT e GLOB, e aumentou os níveis de ALB no grupo FH se comparado ao controle; na comparação intragrupo do grupo $\mathrm{FH}$, os níveis de ALKP, ALT, AST, GGT, TBIL diminuíram, e os níveis da ALB, TP e GLOB aumentaram significantemente.

Mesmo com a diminuição das enzimas ALKP e GGT após o tratamento com os FHs, foi possível observar, um aumento significante na proliferação dos ductos biliares intragrupo para o grupo FH. Este aumento pode estar relacionado a uma das características da droga TAA, em modelos experimentais de indução da cirrose hepática, resultado este, também observado por outros pesquisadores (MOREIRA et al., 1995; FONTANA et al., 1996; ALBADER et al., 2000; JEONG et al., 2001). Índices diminuídos de ALKP e GGT na cirrose hepática indicam melhora da função hepatobiliar (GIANNINI; TESTA; SAVARINO, 2005; MANNING; AFDHAL, 2008; SCHUPPAN; AFDHAL, 2008). O aumento na proliferação dos ductos após o tratamento observado nesta pesquisa, não foi observado por Cogliati et al. (2010) em ratas com fibrose hepática, tratadas com FHs.

As aminotransferases séricas ALT e AST são indicadores confiáveis de alterações funcionais ou estruturais das células hepáticas, e são úteis no diagnóstico de doenças hepáticas (NOGUCHI et al., 2002; OZER et al., 2008). Nesta pesquisa o tratamento com os FHs por 12 dias diminuiu os níveis séricos de AST e ALT, indicando que houve diminuição da lesão 
hepatocelular. Estes resultados também foram apresentados em outros estudos (KAIBORI et al., 1997; GUERRA et al., 2009; COGLIATI et al., 2010).

Índices elevados de AST e ALT indicam respectivamente, a presença de fibrose e injúria hepática (GRIGORESCU, 2006); e aumento na permeabilidade da membrana com conseqüente morte celular (MURIEL; ESCOBAR, 2003).

Apesar dos baixos níveis de ALT e AST observados com o tratamento, houve aumento significativo das inclusões eosinofílicas e da vacuolização nos hepatócitos; pode ser que o tratamento com os FHs por 12 dias não impediu que estas lesões celulares continuassem. $\mathrm{Na}$ cirrose, a estrutura hepatocelular fica prejudicada, os núcleos dos hepatócitos tornam-se lesionados, e a presença de inclusões intranucleares pode ser notada (HENMI; UCHIDA; SHIKATA, 1985).

Outro fator para o aumento significativo das inclusões eosinofílicas e da vacuolização seria a própria toxicidade pela TAA no tecido hepático. Muñoz Torres et al. (1991) relacionam o comprometimento do parênquima ao rompimento de endomembranas, e perda da matriz citoplasmática, com este agente hepatotóxico. A presença de vacuolização e da apoptose hepatocelular leva à fibrose e à insuficiência hepática (DAVIES et al., 1991; BENNER et al., 1992; LAU et al., 1992; WALKER et al., 1993).

O tratamento com os FHs reduziu de forma significativa os índices de GLOB, e aumentou os níveis de ALB no grupo FH se comparado ao controle; na comparação intragrupo do grupo FH, os níveis de TBIL diminuíram, e os níveis da ALB, TP e GLOB aumentaram. A diminuição das enzimas plasmáticas TBIL e GLOB, indica que houve redução de possíveis grandes obstruções das vias biliares. E o aumento na concentração de ALB e TP são sinalizadores que houve possível recuperação do quadro crônico de cirrose devido síntese protéica hepática. Em outros estudos, as concentrações de ALB e TP também aumentaram após o tratamento da fibrose com FHs (COGLIATI et al., 2010).

O tratamento com os FHs diminuiu os níveis de ALT e também reduziu a deposição de glicogênio em 23,08\%, classificada como moderada, e a intensa em 82,25\% se comparada ao CT; mas a deposição aumentou na classificação de moderada e intensa intragrupo FH. A deposição reduzida de glicogênio pode estar relacionada com os baixos níveis de ALT, uma vez que esta enzima catalisa a interconversão do grupamento amino da alanina para o $\alpha$ cetoglutarato formando piruvato e, portanto, desempenha importante função na gliconeogênese e no metabolismo de aminoácidos hepáticos (SCHINDHELM et al., 2006). Já 
o aumento do glicogênio em diversos processos patológicos, é explicado pela diminuição de sua degradação, o que resulta em acúmulos intracelulares anormais (JUNQUEIRA; CARNEIRO, 2004).

O tratamento com os FHs diminuiu a concentração de ALKP e GGT, portanto, os FHs não melhoraram a proliferação de ductos; fator indicativo para a maior deposição de mucopolissacarídeos ácidos observada nos ductos biliares no grupo $\mathrm{FH}$, entretanto, o tratamento evitou que o quadro evoluísse para uma deposição na classificação intensa.

Os mucopolissacarídeos ácidos estão presentes em fígados sofrendo injúrias, e é bem documentado que a administração de TAA por 14 semanas, via oral, promove intensa proliferação de ductos biliares e colangiocarcinoma (AL-BADER et al., 2000). O tratamento prolongado com esta droga leva à displasia do epitélio biliar com produção de mucinas similarmente ao que é observado em colangiocarcinomas humanos (YEH et al., 2004; ZEN et al., 2006). A produção de mucinas pelo epitélio biliar pode estar relacionada ao fato de que as células epiteliais detêm fenótipos gástrico e intestinal (AISHIMA et al., 2008), destacando o padrão glandular de organização dessas estruturas (RIO TINTO et al., 2003). No presente estudo, o tratamento com os FHs evitou que o quadro de cirrose evoluísse para uma deposição intensa de mucopolissacarídeos ácidos.

O tratamento com os FHs por 12 dias em fígados de ratas com cirrose melhorou a função hepática geral e diminuiu o prejuízo no sistema biliar.

No processo de cirrose, as células estreladas hepáticas (CEHs) são ativadas por uma variedade de estímulos fibrogênicos, esta ativação intensifica a deposição de matriz extracelular (MEC), aumentando a liberação de colágeno fibrilar tipo I (FRIEDMAN, 1993; GARCÍA et al., 2002; SCHAEFER et al., 2003) e tipo III (SCHUPPAN et al., 1999; BRENNER et al., 2000; FRIEDMAN, 2000). A proporção total de colágeno pode passar de 2\% para até 30\% do total de proteínas do fígado (PINES et al., 1997; SPIRA et al., 2002).

Nesta pesquisa, o tratamento não alterou o índice de atividade histológica e do estadiamento da fibrose imediatamente após o tratamento, mas os FHs reduziram significantemente a proporção volumétrica do colágeno interlobular em $31,75 \%$ em comparação ao grupo CT e também a apoptose hepatocelular, provavelmente por inibir as CEHs à produção de MEC. Guerra et al. (2009) também encontraram diminuição de 29,6\% do colágeno hepático total após tratamento com FHs; Cogliati et al. (2010) observaram diminuição de $57,7 \%$ e $31,6 \%$ no índice de colágeno perivascular em veias centrais e portais, 
respectivamente, após tratamento com FHs; e Zhang et al. (2006) observaram redução de $11,04 \%$ e 10,17\% de colágeno, respectivamente no grupo que recebeu FHs, e FHs + insulina; similarmente a quantidade do colágeno tipo I e III também foi menor nos animais com hipertensão portal intrahepática induzida pelo $\mathrm{CCl}_{4}$ e tratados com $\mathrm{FHs}$ por 7 dias.

As CEHs proliferam e transformam-se em miofibroblastos ativos, estas células ativadas expressam $\alpha$-actina de músculo liso ( $\alpha$-SMA) e liberam pro-colágeno I (FRIEDMAN, 1993). Nesta pesquisa os FHs reduziram de forma significativa em 53,17\% as células $\alpha$-SMA positivas (CEHs ativadas) em comparação ao grupo CT. Este resultado é um forte indicativo para a diminuição do colágeno interlobular observado.

As proteínas da MEC produzidas pelas CEHs quiescentes são tipicamente depositadas nas membranas basais (laminina, colágeno tipo IV e entactina) enquanto as CEHs ativadas sintetizam mais proteínas (colágeno tipo I) localizadas no interstício (RAMADORI et al., 1990; RAMADORI, 1991; HAUTEKEETE, GEERTS, 1997; SAILE et al., 1999).

É raro ou até mesmo inédito trabalhos que mostram a distribuição das CEHs em fígados com cirrose e tratados com FHs, portanto, os resultados observados nesta pesquisa foram discutidos, baseados em outros tipos de tratamentos. Como no trabalho de He et al. (2006), observaram que a área percentual de células $\alpha$-SMA positivas aumenta na fibrose hepática induzida pelo $\mathrm{CCl}_{4}$; e diminui de forma significativa se tratados com extrato de ginko biloba. Já o tratamento da fibrose hepática com S-nitroso-N-acetilcisteína reduz de forma significante as células $\alpha$-SMA positivas, se comprados àqueles tratados com $\mathrm{N}$-acetilcisteína (VERCELINO et al., 2010).

A TAA por ser um agente hepatotóxico, ativa mediadores inflamatórios capazes de ativar as CEHs, contudo, o tratamento com os FHs por 12 dias, provavelmente inibiu ou diminuiu a proliferação destas células, consequentemente diminuindo a produção e deposição de MEC.

Os FHs não alteraram a proliferação dos hepatócitos imediatamente após o tratamento, mas reduziu de forma significativa a apoptose hepatocelular, e aumentou as células ovais. Este aumento das células ovais provavelmente foi acarretado pela TAA; e na tentativa do fígado se restabelecer, estas células se diferenciaram em hepatócitos ou colangiócitos; um forte indício para o aumento signifiativo na proliferação de ductos do grupo FH. Este resultado não foi apresentado por Cogliati et al. (2010). 
Quando a proliferação hepática é bloqueada ou ocorre extensa perda de hepatócitos, as células ovais são ativadas para restaurar o fígado (KUBOTA et al., 2008). Estas células têm similaridades com os hepatócitos e com as células dos ductos biliares, e aparecem quando a regeneração de hepatócitos maduros é suprimida. As células ovais proliferam à medida que a fibrose avança. Durante o estabelecimento da cirrose, a replicação dos hepatócitos maduros é prejudicada e isto leva à ativação das células ovais (ALISON et al.; 1996, 1997, 1998; LOWES et al., 1999; PAKU et al., 2001; TSAMANDAS et al., 2007).

Particularmente quando a cirrose está presente, há uma íntima associação entre a proliferação de células ovais e o aumento do risco de desenvolvimento de hepatocarcinoma (LOWES et al., 1999). Em humanos, em casos de hepatites crônicas, o número de células ovais está diretamente relacionado ao grau da doença e pode indicar o futuro desenvolvimento de carcinoma hepatocelular (TSAMANDAS et al., 2007).

Em modelos animais, a proliferação de células ovais está associada à presença de células inflamatórias no fígado. Quando colocadas em cultura, as células ovais de animais submetidos à modelos de cirrose, se deterioram rapidamente, sugerindo que fatores exógenos sejam fundamentais para sua manutenção. Assim, citocinas ou outros fatores produzidos pelas células associadas à fibrogênese, como as CEHs e células de Kupffer, podem ser responsáveis por estimular a proliferação e a migração de células ovais (TSAMANDAS et al., 2007). Esta explicação é plausível neste estudo, visto que células inflamatórias puderam ser vistas entre as células ovais.

O tratamento com os FHs diminuiu a expressão do gene colágeno $\alpha 1$, e aumentou os níveis de expressão dos genes TIMP-1, MMP-13 e PLAU, e não alterou os níveis de expressão do TGF $\beta$-1 e da MMP-2 em relação ao grupo CT. Os FHs reduziram a deposição do colágeno tipo I e III, mesmo com esta diminuição na deposição do colágeno, o TIMP-1, principal inibidor da metaloproteinase, continuou elevado, talvez pela quantidade de gelatinas, colágenos desnaturados, e moléculas da MEC ainda presentes no fígado. Estes resultados coincidem aos de Guerra et al., (2009), com relação aos níveis de expressão gênica do colágeno $\alpha 1$ (redução de 53\%) e da MMP-2 (redução de 41,6\%) em ratas tratadas com FHs. E não coincide com outros tipos de tratamento; na fibrose biliar secundária, os níveis de expressão dos genes colágeno $\alpha 1$, TGF $\beta$-1, TIMP-1, TIMP-2, PAI-1 e MMP-13 aumentaram; e no tratamento da fibrose panlobular induzida pela TAA, os níveis dos genes colágeno $\alpha 1$ e TIMP-1 também aumentaram (PATSENKER et al., 2009). Huang et al., (2008) encontraram níveis reduzidos do TIMP-1 no tratamento do carcinoma hepatocelular e da cirrose hepática. 
A MMP-13 é secretada por fibroblastos e pelas CEHs, no entanto, apesar das CEHs produzirem e secretarem a proenzima da MMP-13, elas não são capazes de convertê-la em MMP-13 ativa, para que haja ativação é necessária a contribuição de outras células para a produção de atividades proteolíticas necessárias. Os hepatócitos produzem os fatores necessários para ativação da pro-MMP-13 (SCHAEFER et al., 2003). Por ser uma colagenase intersticial, a forma ativa desta MMP é inibida pelo TIMP; em processos patológicos hepáticos a MMP-13 é rigorosamente regulada pelo TIMP-1 (OKAZAKI et al., 2001).

O PLAU (uPA) é responsável pela conversão de plasminogênio em plasmina, a qual em seguida, ativa uma série de proteases, tais como metaloproteinases de matriz (MMPs), desencadeando a remodelação e degradação da MEC (HE et al., 1989; LEYLAND et al., 1996). A atividade do PLAU está aumentada durante os estágios precoces de fibrose (BENYON, ARTHUR, 2001). A atividade do PLAU é controlada pelos seus inibidores específicos, PAI-1 e PAI-2, importantes reguladores do balanço entre as atividades proteolíticas e antiproteolíticas que determinam o "turnover" da MEC (CUBELLIS; WUN; BLASI, 1990; SEIFFERT et al., 1990; OLSON et al., 1992).

São importantes os resultados alcançados nesta pesquisa com o tratamento com os FHs por 12 dias em ratas com cirrose; houve diminuição da expressão gênica dos principais genes pró-fibrogênicos, como colágeno $\alpha 1$, MMP-13 e PLAU; os índices bioquímicos relacionados à função e excreção hepática, diminuíram; houve redução da apoptose hepatocelular; a deposição de colágeno entre os lóbulos hepáticos diminuíram; as células estreladas hepáticas também reduziram o que implicou em menor deposição dos constituintes da matriz extracelular. Alguns mecanismos também importantes na recuperação hepática não foram melhorados com os FHs, como os níveis de expressão dos genes TGF $\beta$-1 e da MMP-2, a deposição do colágeno intralobular e o índice de proliferação celular; acredito que o tratamento continuado por alguns dias adicionais com os FHs, ou mesmo alteração na formulação destes FHs poderiam melhorar ou resolver estes mecanismos que não se alteraram com o tratamento por 12 dias.

Estes resultados sugerem o uso terapêutico da solução de FHs para tratar doenças hepáticas crônicas. 


\subsection{DISCUSSÃO DOS RESULTADOS OBSERVADOS 60 DIAS PÓS-TRATAMENTO COM OS FATORES HEPATOTRÓFICOS - GRUPO FH ${ }^{+60 d}$ E SEU CONTROLE (CT)}

Os sinais clínicos observados durante o período experimental não foram manifestados em todos os animais. Os animais submetidos ao tratamento com a TAA apresentaram flacidez da pele, posição álgica, diarréia, alopecia, secreção porfirinêmica da glândula de Harder, piloereção e amarelamento da pelagem. O grupo $\mathrm{FH}^{+60 \mathrm{~d}}$ submetido ao tratamento com os $\mathrm{FHs}$ mostraram posição álgica e piloereção. Estes resultados não serão discutidos aqui, pois já foram abordados no item 6.1 .

$\mathrm{O}$ grupo $\mathrm{FH}^{+60 \mathrm{~d}}$ não apresentou nenhum obtido, entretanto, o seu grupo CT apresentou 13,33\% de mortalidade, correspondente a 2 animais; os óbitos ocorreram no final do período de indução da cirrose. Guerra et al. (2009) verificaram índice de óbito de 4\% em animais induzidos à cirrose hepática por 14 semanas; Laleman et al. (2006) observaram um índice de mortalidade de 16\% em 56 animais que foram submetidos à intoxicação pela TAA em água potável por 18 semanas, porém não notaram nenhum óbito nos animais controles e naqueles intoxicados pela TAA por 6 e 12 semanas. Gu et al. (2010) verificaram índice de mortalidade de $4 \%$ em animais induzidos a cirrose pela TAA $(0,03 \%$ de TAA em água potável por 29 semanas).

Durante a administração da TAA, entre as $7^{\mathrm{a}}$ e $11^{\mathrm{a}}$ semanas; e durante o tratamento, da $14^{\mathrm{a}}$ até a $16^{\mathrm{a}}$ semana, os animais do grupo $\mathrm{FH}^{+60 \mathrm{~d}}$ apresentaram pesos significantemente maiores; da $17^{\mathrm{a}}$ a $21^{\mathrm{a}}$ semana, o peso médio do grupo tratado mostrou redução estatisticamente significante, igualando-se ao grupo CT na eutanásia. Um aumento no peso dos animais também foi verificado por Alóia et al. (2010), em ratas sadias tratadas com FHs por 10 dias; Guerra et al. (2009) também observaram que os animais induzidos a cirrose pela TAA perderam peso, posteriormente recuperando entre as $4^{\mathrm{a}}$ e $7^{\mathrm{a}}$ semanas, quando a dose de TAA foi aumentada em $20 \%$. O peso voltou a cair até a $9^{a}$ semana, aumentando posteriormente até a $14{ }^{\mathrm{a}}$ semana. Gu et al. (2010) verificaram que o peso médio inicial, antes da administração da TAA em ratos foi de 239 g, quando a cirrose foi estabelecida, no período de 29 semanas, o peso foi de $368 \mathrm{~g}$.

O efeito do tratamento com os FHs após 60 dias, reduziu a densidade do fígado no grupo $\mathrm{FH}^{+60 \mathrm{~d}}$ em relação ao grupo $\mathrm{CT}$, sugerindo que os efeitos do tratamento a longo prazo 
diminuiu o volume do fígado. Este resultado se assemelha ao de Alóia et al. (2010), que observaram redução de 1,8\% na densidade hepática de ratas sadias tratadas com FHs por 10 dias. Já Guerra et al. (2009) observaram aumento de 11,3\% no peso e volume do fígado de ratas tratadas com FHs. Cogliati et al. (2010) também notaram aumento de 15,5\% no peso do fígado de ratas com fibrose tratadas com FHs por 10 dias.

O fígado tem a habilidade de regular o seu próprio tamanho de acordo com a "influência" trófica que recebe; dentre as principais substâncias hepatotróficas destacam-se os hormônios tireoideanos, a insulina, glucagon, nutrientes e drogas de ação hepatotrófica (MORSIANI et al., 1984). Os FHs aumentam o tamanho do fígado por meio de estímulos regenerativos, esta capacidade regenerativa é atribuída no aumento do número de hepatócitos (PARRA et al., 1992; 1994; 1995b; 1996).

A insulina e o glucagon são hormônios importantes para o trofismo e metabolismo do parênquima hepático. O glucagon estimula a síntese de proteínas hepáticas, e este, juntamente com a insulina, atuam sinergicamente na regulação da regeneração hepática. A ausência de insulina provoca degeneração e morte dos hepatócitos em meio de cultura; porém a insulina não possui efeito mitogênico sobre os hepatócitos, mas potencializa o efeito de outros fatores de crescimento (KALIL; SPERB; LICHTENFELS, 1998; JESUS; WAITZBERG; CAMPOS, 2000; CORPECHOT et al., 2002).

Parra et al. (1992) estudaram o crescimento adicional de fígados sadios induzido por FHs; doses desta solução foram administradas com e sem hormônios e notaram que o grupo que recebeu a solução de FHs com insulina e glucagon apresentou aumento significante de $34,48 \%$ no crescimento da massa hepática.

Sessenta dias após o término do tratamento com os FHs, os níveis bioquímicos de ALB, ALT e TBIL reduziram significantemente, e os índices de GGT e GLOB apresentaram aumento significante no grupo $\mathrm{FH}^{+60 \mathrm{~d}}$ se comparado ao seu controle. Os resultados observados para o grupo $\mathrm{FH}^{+60 \mathrm{~d}}$ sugerem que os efeitos dos $\mathrm{FHs}$ permaneceram, em partes, pois níveis elevados de ALB acarreta diminuição da função hepática, característica típica da doença hepática crônica; por outro lado, os níveis de ALT e TBIL reduziram, consequentemente houve diminuição da lesão hepática e em vias biliares. Após 60 dias do tratamento, GGT e GLOB diminuíram, resultados que indicam que houve melhora de possíveis obstruções do fluxo biliar e da inflamação hepática, respectivamente. 
$\mathrm{Na}$ análise intragrupo do grupo $\mathrm{FH}^{+60 \mathrm{~d}}$, os níveis bioquímicos das enzimas ALKP, ALT, e proteínas GGT, TBIL e GLOB apresentaram redução estatisticamente significante em relação à análise realizada imediatamente após o final do tratamento. Estes resultados indicam que os efeitos dos FHs, sobre o desenvolvimento da cirrose, perduraram com o final da sua administração. Apesar dos níveis diminuídos de ALKP e GGT, indicando que houve redução da colestase intrahepática, foi notado que a proliferação de ductos aumentou intragrupo no grupo $\mathrm{FH}^{+60 \mathrm{~d}}$, característica observada no tecido hepático submetidos ao tratamento com a TAA.

Pós 60 dias do tratamento com os FHs os níveis de ALT e GGT reduziram, este resultado coincide com os de Zhang et al. (2006) que observaram em animais com hipertensão portal intrahepática induzida pela administração intragástria de $\mathrm{CCl}_{4}$, que os níveis séricos de ALT diminuíram em animais tratados com fator de crescimento de hepatócito (HGF) e HGF + insulina, se comparados ao controle, contudo nenhuma diferença foi observada nos níveis de ALT entre os animais tratados com HGF, HGF + insulina ou somente insulina. Animais induzidos a fibrose hepática e tratados com inhame liofilizado também apresentaram redução de ALT e da atividade da GGT (CHAN et al., 2010). Gu et al. (2010) verificaram níveis de ALT e ALKP aumentados, e índices de ALB diminuídos, no dia 0, 30, 60, 90 e 120 dias, pós 29 semanas de indução da cirrose pela TAA $(0,03 \%$ em água potável) se comparados ao controle.

Mesmo com o aumento significante da proliferação de ductos observado na análise intragrupo do grupo $\mathrm{FH}^{+60 d}$; após 60 dias, os efeitos do tratamento reduziram as deposições de mucopolissacarídeos classificadas como moderada em 13,32\%, e a intensa em 56,63\% no grupo $\mathrm{FH}^{+60 \mathrm{~d}}$ em comparação com seu CT. A comparação dentro do grupo tratado com os FHs mostrou que o tratamento não evitou o aumento na deposição; a deposição moderada aumentou $300 \%$ e a intensa aumentou de 0,00 para 6,67\%. Interessantemente, na comparação intergrupo (FH e seu CT) dos animais tratados por 12 dias e eutanasiados, houve maior deposição de mucopolissacarídeo, ou seja, os efeitos dos FHs a longo prazo diminuiu a deposição deste glicosaminoglicano.

$\mathrm{Na}$ cirrose hepática, o conteúdo de colágeno e proteoglicanos pode ser até 6 vezes maior àquele encontrado em fígados saudáveis (ROJKIND; GIAMBRONE; BIEMPICA, 1979). As CEHs e vários componentes da MEC são as principais produtoras de MEC encontrado no tecido cicatricial hepático (IREDALE, 2007). O proteoglicano sulfato de heparan constitui um importante componente da MEC, e contribui para a integridade e 
insolubilidade da MEC. Grande parte deste sulfato pode ser especificamente clivado pela heparanase (PARISH; FREEMAN; HULETT; 2001; VLODAVSKY; FRIEDMANN, 2001), controlando a liberação de fatores de crescimento e potencialmente afetando o processo biológico de remodelação da MEC. A heparanase tem correlação com o potencial metastático de células tumorais (NAKAJIMA; IRIMURA; NICOLSON, 1988; VLODAVSKY et al., 1999) embora, apresente outra função, facilita a invasão celular associada com a autoimunidade, inflamação e angiogênese (DEMPSEY; BRUNN; PLATT, 2000; VLODAVSKY; FRIEDMANN, 2001).

Os efeitos do tratamento depois de 60 dias não alteraram os níveis de AST, mas reduziu os de ALT. Talvez o imbalanço entre estas duas enzimas, tenha acarretado aumento significativo na vacuolização e nas inclusões eosinofílicas no grupo $\mathrm{FH}^{+60 \mathrm{~d}}$ se comparado ao seu controle. A enzima AST está relacionada com a integridade dos hepatócitos (GIANNINI; TESTA; SAVARINO, 2005); e a ALT em alta concentração indica permeabilidade da membrana e, portanto, morte celular (MURIEL; ESCOBAR, 2003). Assim, ALT está relacionada com a injúria hepática, e a AST com a presença de fibrose (GRIGORESCU, 2006).

Após 60 dias do tratamento, houve aumento na deposição do glicogênio no grupo $\mathrm{FH}^{+60 \mathrm{~d}}$, classificado como moderado de $53,85 \%$ para $66,67 \%$, e na classificação intensa houve redução do glicogênio de $30,77 \%$ para $26,67 \%$ se comparado ao seu CT; esta redução não se manteve intragrupo no grupo $\mathrm{FH}^{+60 \mathrm{~d}}$, a deposição moderada sofreu um aumento de $20,00 \%$ para $66,67 \%$ e a intensa se elevou de 0,00 para $26,67 \%$. Pacientes com cirrose apresentam depleção de glicogênio hepático por apresentarem alteração na sua síntese. A degradação prejudicada é observada pela distribuição homogênea desse polissacarídeo nos fígados cirróticos, ao passo que no órgão sadio há maior acúmulo em torno da veia centrolobular. Isto, talvez, se deva ao fato de que as alterações vasculares prejudiquem a circulação do sangue pelo fígado e, conseqüentemente, a captação do glicogênio armazenado (MAIO; DICHI; BURINI, 2000).

Os efeitos dos FHs depois de 60 dias perduraram sobre a função, excreção e biossíntese hepática, pois, os índices bioquímicos das enzimas e proteínas plasmáticas se mantiveram.

O índice de atividade histológica da atividade necro-inflamatória e do estadiamento do grau da fibrose pelos critérios modificados por Ishak et al. (1995) não se alteraram com os efeitos dos FHs pós 60 dias; e houve aumento de 79,97\% de células estreladas positivas no 
grupo $\mathrm{FH}^{+60 \mathrm{~d}}$ em comparação ao grupo $\mathrm{CT}$; as $\mathrm{CEHs}$ quando ativadas sintetizam mais proteínas localizadas no interstício, e interessantemente houve redução de $56 \%$ na deposição do colágeno intralobular no grupo $\mathrm{FH}^{+60 \mathrm{~d}}$ em comparação ao grupo CT. Provavelmente esta deposição diminuída foi mantida pelos efeitos dos FHs depois de 60 dias sobre a expressão dos genes PLAU e MMP-13.

Após restabelecimento do modelo de cirrose hepática pela TAA, a deposição de colágeno é alta, mas se o agente hepatotóxico é afastado, o índice de colágeno reduz gradualmente em um período de observação de 120 dias, mas se comparado ao controle, ainda continua elevado (GU et al., 2010). Guerra et al., (2009) observaram diminuição de 37,1\% do colágeno hepático total no grupo de animais induzidos a cirrose e tratados com FHs se comparados com animais induzidos a cirrose e tratados com solução salina.

Depois de 60 dias do tratamento, o grupo $\mathrm{FH}^{+60 \mathrm{~d}}$ apresentou redução significante de 57,99\% na proliferação dos hepatócitos em relação ao grupo CT; também houve diminuição da apoptose na análise intragrupo do grupo $\mathrm{FH}^{+60 \mathrm{~d}}$; se há diminuição da apoptose, consequentemente deveria ocorrer um aumento da proliferação como uma forma de compensar a morte de hepatócitos, e não a sua diminuição, como a observada nesta pesquisa; outro fator que pode ter ocorrido para a redução da proliferação, foi à diminuição na severidade da lesão causada pelos efeitos dos FHs, por regular o ciclo celular.

Foi demonstrado aumento na positividade dos hepatócitos ao PCNA em ratos tratados com $\mathrm{CCl}_{4}$ (WANG et al., 1999; CHAN et al., 2010), porém este índice foi significantemente inibido em animais induzidos a fibrose hepática e tratados com inhame liofilizado, por diminuir a severidade da lesão hepática por meio da regulação do crescimento celular e pela síntese de DNA.

Os índices do PCNA, em fígados de ratos após estabelecimento da cirrose pela TAA também aumentaram. A TAA estimulou a proliferação hepática, um dia após o término da aplicação do agente hepatotóxico. Após 30 e 60 dias de retirada da TAA a regeneração do fígado foi significativamente desacelerada e permaneceu até 120 dias, ou seja, a TAA inicialmente faz um papel na estimulação da regeneração hepática, e sua retirada resulta em regeneração desacelerada (GU et al., 2010).

A expressão gênica da MMP-13, responsável pela degradação dos colágenos tipo $1 \mathrm{e}$ 3, e do PLAU, ativador indireto das MMPs no grupo $\mathrm{FH}^{+60 \mathrm{~d}}$ aumentaram de forma significativa em relação ao grupo CT; apesar do aumento na expressão de genes envolvidos 
na degradação de componentes da matriz extracelular, a expressão do colágeno tipo I aumentou significantemente. Este aumento na expressão do colágeno tipo I, provavelmente está correlacionado ao aumento das $\mathrm{CEHs}$ verificado no grupo $\mathrm{FH}^{+60 \mathrm{~d}}$; mesmo assim é nítido os efeitos do tratamento sobre a fibrólise hepática que permaneceram pós-tratamento.

O PLAU inibe indiretamente a deposição de MEC por ativar as MMPs secretadas na forma latente (em particular pro-MMP1, -MMP-2, -MMP-3 e -MMP-9) (LIN et al., 2005; GONZÁLEZ-CUEVAS, BUENO-TOPETE, ARMENDARIZ-BORUNDA, 2006).

Durante a ativação das HSCs, a síntese das proteínas da MEC aumenta pelas CEHs, e os padrões das proteínas sintetizadas mudam. As proteínas da MEC produzidas pelas CEHs quiescentes são tipicamente depositadas nas membranas basais (laminina, colágeno tipo IV e entactina) enquanto as CEHs ativadas sintetizam mais proteínas localizadas no interstício, por exemplo, o colágeno tipo I (RAMADORI et al., 1990; RAMADORI, 1991; HAUTEKEETE, GEERTS, 1997; SAILE et al., 1999).

De acordo com o regime de cicatrização e formação de cicatriz, o colágeno tipo III é o primeiro a aumentar após injúria hepática, e posteriormente substituída pelo colágeno tipo I, este último corresponderá de $60 \%$ a $70 \%$ do colágeno total no fígado cirrótico (SEYER, HUTCHESON, KANG, 1977; HAHN et al., 1980; BALLARDINI et al., 1985).

A degradação do colágeno I é realizada pelas colagenases, as MMPs-1, -8 e -13 (LEE et al., 1995; FRIEDMAN, 2000; IIMURO et al., 2003; SCHAEFER et al., 2003).

Os efeitos pós-tratamento com os FHs perduraram sobre alguns mecanismos da cirrose hepática induzida pela TAA. Houve redução dos índices de função, excreção e biossíntese hepática; da apoptose hepatocelular; da deposição de colágeno intersticial (intralobular); redução da proliferação dos hepatócitos; e aumento nos índices de expressão gênica da MMP13 e PLAU. Por outro lado, fatores importantes na melhora da cirrose hepática não se alteraram, como a atividade necro-inflamatória; o estadiamento da fibrose; a deposição do colágeno interlobular; a quantidade de CEHs ativadas; a expressão gênica aumentada de colágeno tipo I, e dos demais que não se alteraram (TGF $\beta$-1, TIMP-1 e MMP-2). Para que os efeitos dos FHs perdurem de maneira mais eficiente pós-tratamento, sugiro que haja a administração destes FHs por um maior período de tempo; períodos de tratamento com os FHs intercalados com períodos de repouso; a alteração na formulação destes FHs, e/ou o acesso por outra via de aplicação, no intuito do aumento da melhora ou mesmo a resolução da cirrose. 


\section{CONCLUSÕES}

Diante dos resultados obtidos com os efeitos dos fatores hepatotróficos (FHs), imediatamente após o tratamento, e 60 dias pós o seu término, na cirrose hepática murina induzida pela tioacetamida (TAA), concluímos:

\subsection{CONCLUSÕES DOS RESULTADOS OBSERVADOS IMEDIATAMENTE APÓS TRATAMENTO COM OS FATORES HEPATOTRÓFICOS - GRUPO FH E SEU CONTROLE (CT)}

1. O tratamento com os FHs não alterou a atividade necro-inflamatória e o grau de fibrose/cirrose hepática após indução pela tioacetamida (TAA);

2. Os FHs melhoraram os índices bioquímicos, pois a função, excreção e biossíntese hepática foram recuperadas;

3. A deposição do colágeno entre os lóbulos hepáticos reduziu-se com o tratamento pelos FHs;

4. O tratamento reduziu a ativação das células estreladas hepáticas;

5. O tratamento não alterou (reduziu) a proliferação dos hepatócitos;

6. O tratamento alterou os mecanismos moleculares envolvidos na fibrogênese hepática, por reduzir a deposição de colágeno tipo I, e aumentar a expressão de genes envolvidos na degradação de colágeno e de outros componentes da MEC. 


\subsection{CONCLUSÕES DOS RESULTADOS OBSERVADOS 60 DIAS PÓS-TRATAMENTO COM OS FATORES HEPATOTRÓFICOS - GRUPO FH ${ }^{+60 \mathrm{~d}}$ E SEU CONTROLE (CT)}

1. Depois de sessenta dias, os efeitos do tratamento com os FHs não alterou a atividade necro-inflamatória e o grau de fibrose/cirrose hepática após indução pela tioacetamida (TAA);

2. Pós-tratamento com os FHs, os índices bioquímicos melhoraram, pois os efeitos benéficos na função, excreção e biossíntese hepática se mantiveram;

3. A deposição do colágeno intralobular (intersticial) reduziu pós-tratamento;

4. Depois de 60 dias do tratamento, houve aumento da ativação das células estreladas hepáticas;

5. Depois de 60 dias houve redução da taxa de proliferação dos hepatócitos;

6. Os efeitos pós-tratamento com os FHs aumentaram a deposição de colágeno tipo I, e a expressão de genes envolvidos na degradação de colágenos tipos I e III, e de outros componentes da MEC.

O tratamento com os FHs por 12 dias melhorou a maioria dos mecanismos que foram alterados na cirrose hepática murina induzida pela TAA; depois de 60 dias pós-tratamento com os FHs algumas destas alterações se mantiveram, porém, outras pioraram. Em síntese, para uma melhora adicional é necessário repetições do tratamento associado com intervalos de repouso; reitero que o tratamento com os FHs pode representar uma importante ferramenta terapêutica no tratamento da cirrose hepática em humanos e animais. 


\section{REFERÊNCIAS}

ABDEL-AZIZ, G.; LEBEAU, G.; RESCAN, P. Y.; CLÉMENT, B.; RISSEL, M.; DEUGNIER, Y.; CAMPION, J. P.; GUILLOUZO, A. Reversibility of hepatic fibrosis in experimentally induced cholestasis in rat. The American Journal of Pathology, v. 137, n. 6, p. 1333-1342, 1990.

AIMES, R. T.; QUIGLEY, J. P. Matrix metalloproteinase-2 is an interstitial collagenase. Inhibitor-free enzyme catalyzes the cleavage of collagen fibrils and soluble native type I collagen generating the specific 3/4- and 1/4-length fragments. The Journal of Biological Chemistry, v. 270, n. 11, p. 5872-5876, 1995.

AISHIMA, S.; NISHIHARA, Y.; TSUJITA, E.; TAGUCHI, K.; SOEJIMA, Y.; TAKETOMI, A.; IKEDA, Y.; MAEHARA, Y.; TSUNEYOSHI, M. Biliary neoplasia with extensive intraductal spread associated with liver cirrhosis: a hitherto unreported variant of biliary intraepithelial neoplasia. Human Pathology, v. 39, n. 6, p. 939-947, 2008.

AL-BADER, A.; MATHEW, T. C.; ABUL, H.; AL-SAYER, H.; SINGAL, P. K.; DASHTI, H. M. Cholangiocarcinoma and liver cirrhosis in relation to changes due to thioacetamide. Molecular and Cellular Biochemistry, v. 208, n. 1-2, p. 1-10, 2000.

ALBANIS, E.; FRIEDMAN, S. L. Antifibrotic agents for liver disease. American Journal of Transplantation, v. 6, n. 1, p.12-19, 2006.

ALBERINO, F.; GATTA, A.; AMODIO, P.; MERKEL, C.; DI PASCOLI, L.; BOFFO, G.; CAREGARO, L. Nutrition and survival in patients with liver cirrhosis. Nutrition, v. 17, n. 6 , p. 445-450, 2001.

ALISON, M. R.; GOLDING, M.; SARRAF, C.; EDWARDS, R. J.; LALANI, E. N. Liver damage in the rat induces hepatocyte stem cells from biliary epithelial cells.

Gastroenterology, v. 110, n. 4, p. 1182-1190, 1996.

ALISON, M.; GOLDING, M.; LALANI, E. N.; NAGY, P.; THORGEIRSSON, S.; SARRAF, C. Wholesale hepatocytic differentiation in the rat from ductular oval cells, the progeny of biliary stem cells. Journal of Hepatology, v. 26, n. 2, p. 343-352, 1997.

ALISON, M.; GOLDING, M.; LALANI, EL-N.; SARRAF, C. Wound healing in the liver with particular reference to stem cells. Philosophical Transactions of the Royal Society of London. Series B, Biological Sciences, v. 353, n. 1370, p. 877-894, 1998.

ALÓIA, T. P. A.; COGLIATI, B.; GUERRA, R. R.; PARRA, O. M.; DAGLI, M. L. Z.; HERNANDEZ-BLAZQUEZ, F. J. Modelo de suplementação nutricional com fatores hepatotróficos aumenta proliferação celular em fígado de ratos sadios. Arquivo Brasileiro de Medicina Veterinária e Zootecnia, v. 62, n. 4, p. 853-861, 2010.

\footnotetext{
* De acordo com "Diretrizes para apresentação de dissertações e teses na Faculdade de Medicina Veterinária e Zootecnia da Universidade de São Paulo”, 2003.
} 
AN, W.; LIU, X. J.; LEI, T. G.; DAI, J.; DU, G. G. Growth induction of hepatic stimulator substance in hepatocytes through its regulation on EGF receptors. Cell Research, v. 9, n. 1, p. 37-49, 1999.

ANDERSSON, M.; SEVELIUS, E. Breed, sex and age distribution in dogs with chronic liver disease: a demographic study. Journal of Small Animal Practice, v. 32, n. 1, p. 1-5, 1991.

ANDRADE, Z. A. Regressão da fibrose hepática. Revista da Sociedade Brasileira de Medicina Tropical, v. 38, n. 6, p. 514-520, 2005.

ANTHONY, P. P.; ISHAK, K. G.; NAYAK, N. C.; POULSEN, H.; SCHEUER, P. J.; SOBIN, L. H. The morphology of cirrhosis: definition, nomenclature and classification. Bulletin of the World Health Organization, v. 55, n.4, p. 521-540, 1977.

ARIAS, I. M.; BOYER, J. L.; FAUSTO, N.; JACOBY, W. B.; SCHACHTER, D.; SHAFRITZ, D. A. The liver: biology and pathobiology. 3. ed. New York: Raven, 1994. 1628 p.

ARTHUR, M. J. Matrix degradation in liver. Seminars in Liver Disease, v. 10, n. 1, p. 47 55,1990 .

BAKER, A. L. Hepatotrophic factors: concepts and clinical implications. Acta Medica Scandinavica. Supplementum, v. 703, p. 201-208, 1985.

BALLARDINI, G.; FACCANI, A.; FALLANI, M.; BERTI, S.; VASI, V.; CASTALDINI, C.; BIAGINI, G.; GARBISA, S.; BIANCHI, F. B. Sequential behaviour of extracellular matrix glycoproteins in an experimental model of hepatic fibrosis. Virchous Archiv. B, Cell Pathology Including Molecular Pathology, v. 49, n. 4, p. 317-324, 1985.

BANCROFT, J. D.; GAMBLE, M. Theory and practice of histological techniques. 5. ed. Edinburgh; London: Churchill Livingstone, 2002. 796 p.

BANKS, W. J. Histologia veterinária aplicada. 2. ed. São Paulo: Manole, 1992. 629 p.

BARATTA, B.; RIZZOLI, R.; GALLIANI, I.; VITALE, M. Early events of liver regeneration in rats: a multiparametric analysis. Histochemical Cellular Biology, v. 105, n. 1, p. 61-69, 1996.

BARMINA, O. Y.; WALLING, H. W.; FIACCO, G. J.; FREIJE, J. M.; LÓPEZ-OTÍN, C.; JEFFREY, J. J.; PARTRIDGE, N. C. Collagenase-3 binds to a specific receptor and requires the low density lipoprotein receptor-related protein for internalization. The Journal of Biological Chemistry, v. 274, n. 42, p. 30087-30093, 1999.

BARRETT, A. J.; STARKEY, P. M. The interaction of alpha 2-macroglobulin with proteinases. Characteristics and specificity of the reaction, and a hypothesis concerning its molecular mechanism. The Biochemical Journal, v. 133, n. 4, p. 709-724, 1973.

BATALLER, R.; BRENNER, D. A. Liver fibrosis. The Journal of Clinical Investigation, v. 115 , n. 2, p. 209-218, 2005. 
BEDOSSA, P.; PARADIS, V. Liver extracellular matrix in health and disease. Journal of Pathology, v. 200, n. 4, p. 504-515, 2003.

BELIN, D.; WOHLWEND, A.; SCHLEUNING, W. D.; KRUITHOF, E. K.; VASSALLI, J. D. Facultative polypeptide translocation allows a single mRNA to encode the secreted and cytosolic forms of plasminogen activators inhibitor 2. The EMBO Journal, v. 8, n. 11, p. 3287-3294, 1989.

BELlENTANI, S.; POZZATO, G.; SACCOCCIO, G.; CROVATTO, M.; CROCÈ, L. S.; MAZZORAN, L.; MASUTTI, F.; CRISTIANINI, G.; TIRIBELLI, C. Clinical course and risk factors of hepatitis $C$ virus related liver disease in the general population: report from the Dionysos study. Gut, v. 44, n. 6, p. 874-880, 1999.

BELLENTANI, S.; SACCOCCIO, G.; COSTA, G.; TIRIBELLI, C.; MANENTI, F.; SODDE, M.; SAVERIA CROCÈ, L.; SASSO, F.; POZZATO, G.; CRISTIANINI, G.; BRANDI, G. Drinking habits as cofactors of risk for alcohol induced liver damage. The Dionysos Study Group. Gut, v. 41, n. 6, p. 845-850, 1997.

BENNER, K. G.; LEE, R. G.; KEEFFE, E. B.; LOPEZ, R. R.; SASAKI, A. W.; PINSON, C. W. Fibrosing cytolytic liver failure secondary to recurrent hepatitis B after liver transplantation. Gastroenterology, v. 103, n. 4, p. 1307-1312, 1992.

BENTEN, D.; KUMARAN, V.; JOSEPH, B.; SCHATTENBERG, J.; POPOV, Y.; SCHUPPAN, D.; GUPTA, S. Hepatocyte Transplantation activates hepatic stellate cells with beneficial modulation of cell engraftment in the rat. Hepatology, v. 42, n. , p. 1072-1081, 2005.

BENYON, R. C.; ARTHUR, M. J. Extracellular matrix degradation and the role of hepatic stellate cells. Seminars in Liver Disease, v. 21, n. 3, p. 373-384, 2001.

BILZER, M.; ROGGEL, F.; GERBES, A. L. Role of Kupffer cells in host defense and liver disease. Liver International: Official Journal of the International Association for the Study of the Liver, v. 26, n. 10, p. 1175-1186, 2006.

BLANC, P.; ETIENNE, H.; DAUJAT, M.; FABRE, I.; ZINDY, F.; DOMERGUE, J.; ASTRE, C.; SAINT, A. B.; MICHEL, H.; MAUREL, P. Mitotic responsiveness of cultured adult human hepatocytes to epidermal growth factor, transforming growth factor alpha, and human serum. Gastroenterology, v. 102, p. 1340-1350, 1992.

BLASI, F.; BEHRENDT, N.; CUBELLIS, M. V.; ELLIS, V.; LUND, L. R.; MASUCCI, M. T.; MØLLER, L. B.; OLSON, D. P.; PEDERSEN, N.; PLOUG, M.; RONNE, E.; DANO, K. The urokinase receptor and regulation of cell surface plasminogen activation. Cell Differentiation and Development: the Official Journal of the International Society of Developmental Biologists, v. 32, n. 3, p. 247-253, 1990.

BODE, W.; GOMIS-RÜTH, F. X.; STÖCKLER, W. Astacins, serralysins, snake venom and matrix metalloproteinases exhibit identical zinc-binding environments (HEXXHXXGXXH and Met-turn) and topologies and should be grouped into a common family, the 'metzincins'. FEBS Letters, v. 331, n. 1-2, p. 134-140, 1993. 
BONACCHI, A.; ROMAGNANI, P.; ROMANELLI, R. G.; EFSEN, E.; ANNUNZIATO, F.; LASAGNI, L.; FRANCALANCI, M.; SERIO, M.; LAFFI, G.; PINZANI, M.; GENTILINI, P.; MARRA, F. Signal transduction by the chemokine receptor CXCR3: activation of Ras/ERK, Src, and phosphatidylinositol 3-kinase/Akt controls cell migration and proliferation in human vascular pericytes. The Journal of Biological Chemistry, v. 276, n. 13, p. 9945 9954, 2001.

BOOMKENS, S. Y.; PENNING, L. C.; EGBERINK, H. F.; VAN DEN INGH, T. S.; ROTHUIZEN, J. Hepatitis with special reference to dogs. A review on the pathogenesis and infectious etiologies, including unpublished results of recent own studies. The Veterinary Quarterly, v. 26, n. 3, p. 107-114, 2004.

BORGES, V. C.; FERRINI, M. T.; WAITZBERG, D. L. Vitaminas. In: WAITZBERG, D. L. Nutrição enteral e parenteral na prática clínica. Rio de Janeiro: Livraria Atheneu, 1990. p. 37-51.

BORKHAM-KAMPHORST, E.; VAN ROEYEN, C. R.; OSTENDORF, T.; FLOEGE, J.; GRESSNER, A. M.; WEISKIRCHEN, R. Pro-fibrogenic potential of PDGF-D in liver fibrosis. Journal of Hepatology, v. 46, n. 6, p. 1064-1074, 2007.

BOURLIERE, M.; PENARANDA, G.; RENOU, C.; BOTTA-FRIDLUND, D.; TRAN, A.; PORTAL, I.; LECOMTE, L.; CASTELLANI, P.; ROSENTHAL-ALLIERI, M. A.; GEROLAMI, R.; OUZAN, D.; DEYDIER, R.; DEGOTT, C.; HALFON, P. Validation and comparison of indexes for fibrosis and cirrhosis prediction in chronic hepatitis $\mathrm{C}$ patients: proposal for a pragmatic approach classification without liver biopsies. Journal of Viral Hepatitis, v. 13, n. 10, p. 659-670, 2006.

BRANDÃO, D. F.; RAMALHO, L. N. Z.; RAMALHO, F. S.; ZUCOLOTO, S.; MARTINELLI, A. L. C.; CASTRO E SILVA, O. Liver cirrhosis and hepatic stellate cells. Acta Cirúrgica Brasileira, v. 21, p. 54-57, 2006. Supllement 1.

BRAVO, R.; CELIS, J. E. A search for differential polypeptide synthesis throughout the cell cycle of HeLa cells. The Journal of Cell Biology, v. 84, n. 3, p. 795-802, 1980.

BRAVO, R.; FRANK, R.; BLUNDELL, P. A.; MACDONALD-BRAVO, H. Cyclin/PCNA is the auxiliary protein of DNA polymerase-delta. Nature, v. 326, n. 6112, p. 515-517, 1987.

BREITKOPF, K.; GODOY, P.; CIUCLAN, L.; SINGER, M. V.; DOOLEY, S. TGFbeta/Smad signaling in the injured liver. Zeitschrift für Gastroenterologie, v. 44, n. 1, p. 57$66,2006$.

BRENNER, D. A.; WATERBOER, T.; CHOI, S. K.; LINDQUIST, J. N.; STEFANOVIC, B.; BURCHARDT, E.; YAMAUCHI, M.; GILLAN, A.; RIPPE, R. A. New aspects of hepatic fibrosis. Journal of Hepatology, v. 32, p. 32-38, 2000. Supllement 1.

BRISTOW, L. J.; YOUNG, L. Chromodacryorrhea and repetitive hind paw tapping: Models of peripheral and central tachykinin NK1 receptor activation in gerbils. European Journal of Pharmacology, v. 253, n. 3, p. 245-252, 1994. 
BROWN, D. L.; VAN WINKLE, T.; CECERE, T.; RUSHTON, S.; BRACHELENTE, C.; CULLEN, J. M. Congenital hepatic fibrosis in 5 dogs. Veterinary Pathology, v. 47, n. 1, p. 102-127, 2010.

BRUCK, R.; ASHKENAZI, M.; WEISS, S.; GOLDINER, I.; SHAPIRO, H.; AEED, H.; GENINA, O.; HELPERN, Z.; PINES, M. Prevention of liver cirrhosis in rats by curcumin. Liver International, v. 27, n. 3, p. 373-383, 2007.

CABRE, E.; GONZALEZ-HUIX, F.; ABAD-LACRUZ, A.; ESTEVE, M.; ACERO, D.; FERNANDEZ-BAÑARES, F.; XIOL, X.; GASSULL, M. A. Effect of total enteral nutrition on the short-term outcome of severely malnourished cirrhotics. Gastroenterology, v. 98, n. 3, p. $715-720,1990$.

CADRANEL, J. F.; RUFAT, P.; DEGOS, F. Practices of liver biopsy in France: results of a prospective nationwide survey. For the Group of Epidemiology of the French Association for the Study of the Liver (AFEF). Hepatology, v. 32, n. 3, p. 477-481, 2000.

CALABRESE, F.; VALENTE, M.; GIAEOMETTI, C.; PETTENAZZO, E.; BENVEGNU, L.; ALBERTI, A.; GATTA, A.; PONTISSO, P. Parenchymal transforming growth faetor $\beta 1$ : Its type II receptor and Smad signaling pathway correlate with inflammation and fibrosis in chronic liver disease of viral etiology. Journal of Gastroenterology and Hepatology, v. 18, n. 11, p. 1302-1308, 2003.

CALES, P.; ZABOTTO, B.; MESKENS, C.; CAUCANAS, J. P.; VINEL, J. P.; DESMORAT, H.; FERMANIAN, J.; PASCAL. J. P. Gastroesophageal endoscopic features in cirrhosis. Observer variability, interassociations, and relationship to hepatic dysfunction.

Gastroenterology, v. 98, p. 156-162, 1990.

CANBAY, A.; FELDSTEIN, A. E.; HIGUCHI, H.; WERNEBURG, N.; GRAMBIHLER, A.; BRONK, S. F.; GORES, G. J. Kupffer cell engulfment of apoptotic bodies stimulates death ligand and cytokine expression. Hepatology, v. 38, n. 5, p. 1188-1198, 2003 a.

CANBAY, A.; TAIMR, P.; TOROK, N.; HIGUCHI, H.; FRIEDMAN, S.; GORES, G. J. Apoptotic body engulfment by a human stellate cell line is profibrogenic. Laboratory Investigation; a Journal of Technical Methods and Pathology, v. 83, n. 5, p. 655-663, 2003 b.

CAREGARO, L.; ALBERINO, F.; AMODIO, P.; MERKEL, C.; BOLOGNESI, M.; ANGELI, P.; GATTA, A. Malnutrition in alcoholic and virus-related cirrhosis. The American Journal of Clinical Nutrition, v. 63, n. 4, p. 602-609, 1996.

CARO, A. A.; CEDERBAUM, A. I. Inhibition of CYP2E1 catalytic activity in vitro by Sadenosyl-L-methionine. Biochemical Pharmacology, v. 69, n. 7, p. 1081-1093, 2005.

CARRIERO, M. V.; LONGANESI-CATTANI, I.; BIFULCO, K.; MAGLIO, O.; LISTA, L.; BARBIERI, A.; VOTTA, G.; MASUCCI, M. T.; ARRA, C.; FRANCO, R.; DE ROSA, M.; STOPPELLI, M. P.; PAVONE, V. Structure-based design of an urokinase-type plasminogen activator receptor-derived peptide inhibiting cell migration and lung metastasis. Molecular Cancer Therapeutics, v. 8, n. 9, p. 2708-2717, 2009. 
CERWENKA, A.; SWAIN, S. L. TGF- $\beta 1$ : immunosuppressant and viability factor for T lymphocytes. Microbes and Infection / Institut Pasteur, v. 1, n. 15, p. 1291-1296, 1999.

CHAN, Y-C.; CHANG, S-C.; LIU, S-Y.; YANG, H-L.; HSEU, Y-C.; LIAO, J-W. Beneficial effects of yam on carbon tetrachloride-induced hepatic fibrosis in rats. Journal of the Science of Food and Agriculture, v. 90, n. 1, p. 161-167, 2010.

CHEN, Y. P.; DAI, L.; WANG, J. L.; ZHU, Y. F.; FENG, X. R.; HOU, J. L. Model consisting of ultrasonographic and simple blood indexes accurately identify compensated hepatitis B cirrhosis. Journal of Gastroenterology and Hepatology, v. 23, n. 8, p. 12281234, 2008.

CHILAKAPATI, J.; SHANKAR, K.; KORRAPATI, M. C.; HILL, R. A.; MEHENDALE, H. M. Saturation toxicokinetics of thioacetamide: Role in initiation of liver injury. Drug Metabolism and Disposition, v. 33, n. 12, p. 1877-1885, 2005.

CHUNG, L.; DINAKARPANDIAN, D.; YOSHIDA, N.; LAUER-FIELDS, J. L.; FIELDS, G. B.; VISSE, R.; NAGASE, H. Collagenase unwinds triple-helical collagen prior to peptide bond hydrolysis. The EMBO Journal, v. 23, n. 15, p. 3020-3030, 2004.

CLARK, J. M. The epidemiology of nonalcoholic fatty liver disease in adults. Journal of Clinical Gastroenterology, v. 40, p. S5-S10, 2006. Supllement 1.

CLARKE, P. R.; ALLAN, L. A. Cell-cycle control in the face of damage--a matter of life or death. Trends in Cell Biology, v. 19, n. 3, p. 89-98, 2009.

COGLIATI, B.; PEREIRA, H, De M.; DAGLI, M. L. Z; PARRA, O. M.; SILVA, J. R, M. C.; HERNANDEZ-BLAZQUEZ, F. J. Hepatotrophic factors reduce hepatic fibrosis in rats.

Arquivos de Gastroenterologia, v. 47, n. 1, p. 79-85, 2010.

COLLEN, D. Ham-Wasserman lecture: role of the plasminogen system in fibrin-homeostasis and tissue remodeling. Hematology / The Education Program of the American Society of Hematology. American Society of Hematology. Education Program, p. 1-9, 2001.

CONN, H. O. Is protein-losing enteropathy a significant complication of portal hypertension. The American Journal of Gastroenterology, v. 93, n. 1, p. 127-128, 1998.

CONN, H. O.; ATTERBURY, C. E. Cirrhosis. In: SCHIFF, L.; SCHIFF, E. (Ed.). Diseases of the liver. Philadelphia: JB Lippincott, 1987. v. 20, p. 825-864.

CORMACK, D. H. Fundamentos de histologia. 2. ed. Rio de Janeiro: Guanabara Koogan, 2003. p. 371.

CORPECHOT, C.; BARBU, V.; WENDUM, D.; CHIGNARD, N.; HOUSSET, C.;

POUPON, R. ROSMORDUC, O. Hepatocyte growth factor and c-met inhibition by hepatic cell hipoxia. A potential mechanism for liver regeneration failure in experimental cirrhosis.

American Journal of Pathology, v. 160, n. 2, p. 613-620, 2002. 
CUBELLIS, M. V.; WUN, T. C.; BLASI, F. Receptor-mediated internalization and degradation of urokinase is caused by its specific inhibitor PAI-1. The EMBO Journal, v. 9, n. 4, p. 1079-1085, 1990.

DALAKAS, E.; NEWSOME, P. N.; HARRISON, D. J.; PLEVRIS, J. N. Hematopoietic stem cell trafficking in liver injury. The FASEB Journal: official publication of the Federation of American Societies for Experimental Biology, v. 19, p. 1225-1231, 2005.

DAVID, P.; ALEXANDRE, E.; CHENARD-NEU, M.; WOLF, P.; JAECH, D.; RICHERT, L. Failure of liver cirrhosis induction by thioacetamide in Nagase analbuminaemic rats.

Laboratory Animals, v. 36, n. 2, p. 158-164, 2002.

DAVIES, S. E.; PORTMANN, B. C.; O’GRADY, J. G.; ALDIS, P. M.; CHAGGAR, K.; ALEXANDER, G. J.; WILLIAMS, R. Hepatic histological findings after transplantation for chronic hepatitis B virus infection, including a unique pattern of fibrosing cholestatic hepatitis. Hepatology, v. 13, n. 1, p. 150-157, 1991.

DAYOUB, R.; THASLER, W. E.; BOSSERHO, A. K.; SINGER, T.; JAUCH, K-W.; SCHLITT, H. J.; WEISS, T. S. Regulation of polyamine synthesis in human hepatocytes by hepatotrophic factor augmenter of liver regeneration. Biochemical and Biophysical

Research Communications, v. 345, n. 1, p. 181-187, 2006.

DEMPSEY; L. A.; BRUNN, G. J.; PLATT, J. L. Heparanase, a potential regulator of cellmatrix interactions. Trends in Biochemical Sciences, v. 25, n. 8, p. 349-351, 2000.

DENNLER, S.; GOUMANS, M. J.; TEN DIJKE, P. Transforming growth factor beta signal transduction. Journal of Leukocyte Biology, v. 71, n. 5, p. 731-740, 2002.

DESMET, V. J.; ROSKAMS, T. Cirrhosis reversal: a duel between dogma and myth. Journal of Hepatology, v. 40, n. 5, p. 860-867, 2004.

DÍAZ-GIL, J. J.; MUÑOZ, J.; ALBILlOS, A.; RÚA, C.; MACHÍN, C.; GARCÍA-CAÑERO, R.; CERECEDA, R. M.; GUIJARRO, M. C.; TRILLA, C.; ESCARTÍN, P. Improvement in liver fibrosis, functionality and hemodynamics in CCl4- cirrhotic rats after injection of the Liver Growth Factor. Journal of Hepatology, v. 30, n. 6, p. 1065-1072, 1999.

DILL-MACKY, E. Chronic hepatitis in dogs. The Veterinary Clinics of North America. Small Animal Practice, v. 25, n. 2, p. 387-398, 1995.

EGEBLAD, M.; WERB, Z. New functions for the matrix metalloproteinases in cancer progression. Nature Reviews. Cancer, v. 2, n. 3, p. 161-174, 2002.

ENGLISH, W. R.; HOLTZ, B.; VOGT, G.; KNÄUPER, V.; MURPHY, G. Characterization of the role of the "MT-loop" - An eight-amino acid insertion specific to progelatinase A (MMP2) activating membrane-type matrix metalloproteinases. The Journal of Biological Chemistry, v. 276, n. 45, p. 42018-42026, 2001.

FARBER, E. Similarities in the sequence of early histological changes induced in the liver of the rat by ethionine, 2-acetylamino-fluorene, and 3'-methyl-4-dimethylaminoazobenzene.

Cancer Research, v. 16, n. 2, p. 142-148, 1956. 
FARRELL, G. C.; LARTER, C. Z. Nonalcoholic fatty liver disease: from steatosis to cirrhosis. Hepatology, v. 43, n. 2, p. S99-S112, 2006. Supllement 1.

FAUSTO, N. Liver regeneration. Journal of Hepatology, v. 32, p. 19-31, 2000. Supllement 1.

FAUSTO, N.; CAMPBELL, J. S.; RIEHLE, K. J. Liver regeneration. Hepatology, v. 43, n. 2, p. 45-53, 2006. Supllement 1.

FAUSTO, N.; LAIRD, A. D.; WEBBER, E. M. Liver regeneration 2: role of growth factors and cytokines in hepatic regeneration. Faseb Journal, v. 9, n. 15, p. 1527-1536, 1995.

FONTANA, L.; MOREIRA, E.; TORRES, M. I.; FERNÁNDEZ, M. I.; RÍOS, A.; SÁNCHEZ DE MEDINA, F.; GIL, A. Serum amino acid changes in rats with thioacetamideinduced liver cirrhosis. Toxicology, v. 106, n. 1-3, p. 197-206, 1996.

FOUTCH, P. G.; SULLIVAN, J. A.; GAINES, J. A.; SANOWSKI, R. A. Cutaneous vascular spiders in cirrhotic patients: correlation with hemorrhage from esophageal varices. The American Journal of Gastroenterology, v. 83, n. 7, p. 723-726, 1988.

FRANCAVILLA, A.; ZENG, Q.; POLIMENO, L.; CARR, B. I.; SUN, D.; PORTER, K. A.; VAN THIEL, D. H.; STARZL, T. E. Small-for-size liver transplanted into larger recipient: a model of hepatic regeneration. Hepatology, v. 19, n. 1, p. 210-216, 1994.

FRASER, I. A.; SHAFFER, P.; TUTTLE, S. V.; LESSLER, M. A.; ELLISON, E. C.; CAREY, L. C. Hepatic recovery after biliary decompression of experimental obstructive jaundice. American Journal of Surgery, v. 158, n. 5, p. 423-427, 1989.

FREIRE, R.; MANGUALDE, J.; VIEIRA, A. M.; LOBATO, C.; ALVES, A. L.; CREMERS, M. I.; AUGUSTO, F.; CAETANO, F.; OLIVEIRA, A. P. Síndrome hepatopulmonar em doentes com cirrose hepática: importância da sua pesquisa sistemática e impacto no prognóstico. Jornal Português de Gastrenterologia, v. 14, p. 176-183, 2007.

FRIEDMAN, S. L. Cytokine and fibrogenesis. Seminars in Liver Disease, v. 19, n. 2, p. 129-140, 1999.

FRIEDMAN, S. L. Hepatic fibrosis - overview. Toxicology, v. 254, n. 3, p. 120-129, 2008b.

FRIEDMAN, S. L. Mechanisms of hepatic fibrogenesis. Gastroenterology, v. 134, n. 6, p. 1655-1669, 2008a.

FRIEDMAN, S. L. Mechanisms of hepatic fibrosis and therapeutic implications. Nature Clinical Practice. Gastroenterology \& Hepatology, v. 1, n. 2, p. 98-105, 2004.

FRIEDMAN, S. L. Molecular regulation of hepatic fibrosis, an integrated cellular response to tissue injury. The Journal of Biological Chemistry, v. 275, n. 4, p. 2247-2250, 2000.

FRIEDMAN, S. L. Seminars in medicine of the Beth Israel Hospital, Boston. The cellular basis of hepatic fibrosis. Mechanisms and treatment strategies. New England Journal of Medicine, v. 328, n. 25, p. 1828-1835, 1993. 
FRIEDMAN, S. L.; WEI, S.; BLANER, W. S. Retinol release by activated rat hepatic lipocytes: regulation by Kupffer cell-conditioned medium and PDGF. The American Journal of Physiology, v. 264, n. 5, Pt. 1, p. G947-G952, 1993.

FRIEDMAN, S.; SCHIANO, T. Cirrhosis and its sequelae. In: GOLDMAN, L.; AUSIELLO, D. Cecil textbook of medicine. 22. ed. Philadelphia, Pa: Saunders, 2004. p. 936-944.

FUENTEALBA, C.; GUEST, S.; HAYWOOD, S.; HORNEY, B. Chronic hepatitis: a retrospective study in 34 dogs. Canadian Veterinary Journal, v. 38, n. 6, p. 365-373, 1997.

FUJIMOTO, J. Gene therapy for liver cirrhosis. Journal of Gastroenterology \& Hepatology, v. 15, p. 33-36, 2000. Supllement.

GABRIEL, S. Population genetic tools: application to cancer. Seminars in Oncology, v. 34, p. S21-S4, 2007. Supplement 1.

GAINES, D. I.; FALLON, M. B. Hepatopulmonary syndrome. Liver International, v. 24, n. 5, p. 397-401, 2004.

GAO, R.; BRIGSTOCK, D. R. Connective tissue growth factor (CCN2) induces adhesion of rat activated hepatic stellate cells by binding of its $\mathrm{C}$-terminal domain to integrin alpha(v)beta(3) and heparan sulfate proteoglycan. The Journal of Biological Chemistry, v. 279, n. 10, p. 8848-8855, 2004.

GARCÍA, L.; HERNÁNDEZ, I.; SANDOVAL, A.; SALAZAR, A.; GARCIA, J.; VERA, J.; GRIJALVA, G.; MURIEL, P.; MARGOLIN, S.; ARMENDARIZ-BORUNDA, J. Pirfenidone effectively reverses experimental liver fibrosis. Journal of Hepatology, v. 37, n. 6, p. 797$805,2002$.

GARCIA-BAÑUELOS, J.; SILLER-LOPEZ, F.; MIRANDA, A.; AGUILAR, L. K.; AGUILAR-CORDOVA, E.; ARMENDARIZ-BORUNDA, J. Cirrhotic rat livers with extensive fibrosis can be safely transduced with clinical-grade adenoviral vectors. Evidence of cirrhosis reversion. Gene Therapy, v. 9, n. 2, p. 127-134, 2002.

GARRETT-LASTER, M.; RUSSELL, R. M.; JACQUES, P. F. Impairment of taste and olfaction in patients with cirrhosis: the role of vitamin A. Human Nutrition. Clinical Nutrition, v. 38, n. 3, p. 203-214, 1984.

GARTNER, L. P.; HIAT, L. P. Tratado de histologia. 2. ed. Rio de Janeiro: Guanabara Koogan, 2003. p. 456.

GAWRIEH, S.; PAPOUCHADO, B. G.; BURGART, L. J.; KOBAYASHI, S.; CHARLTON, M. R.; GORES, G. J. Early hepatic stellate cell activation predicts severe hepatitis C recurrence after liver transplantation. Liver transplantation: official publication of the American Association for the Study of Liver Diseases and the International Liver Transplantation Society, v. 11, n. 10, p. 1207-1213, 2005.

GEERTS, A.; GREENWEL, P.; CUNNINGHAM, M.; BLESER, P. de; ROGIERS, V.; WISSE, E.; ROJKIND, M. Identification of connective tissue gene transcripts in freshly 
isolated parenchymal, endothelial, kupffer and fat-storing cells by Northern hybridization analysis. Journal of Hepatology, v. 19, n. 1, p. 134-143, 1993.

GEORGE, J.; RAO, K. R.; STERN, R.; CHANDRAKASAN, G. Dimethylnitrosamineinduced liver injury in rats: the early deposition of collagen. Toxicology, v. 156, n. 2-3, p. 129-138, 2001.

GEORGE, J.; WANG, S. S.; SEVCSIK, A. M.; SANICOLA, M.; CATE, R. L.; KOTELIANSKY, V. E.; BISSELL, D. M. Transforming growth factor-beta initiates wound repair in rat liver through induction of the EIIIA-fibronectin splice isoform. The American Journal of Pathology, v. 156, n. 1, p. 115-124, 2000.

GERACI, J. R.; MEDWAY, W. Simulated Field blood studies in the bottle-nosed dolphin Tursiops truncatus. 2. Effects of stress on soe hematologic and plasma chemical parameters. Journal of Wildlife Diseases, v. 9, n. 1, p. 29-33, 1973.

GETHING, M. J.; ADLER, B.; BOOSE, J. A.; GERARD, R. D.; MADISON, E. L.; MCGOOKEY, D.; MEIDELL, R. S.; ROMAN, L. M.; SAMBROOK, J. Variants of human tissue-type plasminogen activator that lack specific structural domains of the heavy chain.

The EMBO Journal, v. 7, n. 9, p. 2731-2740, 1988.

GIANNINI, E. G.; TESTA, R.; SAVARINO, V. Liver enzyme alteration: a guide for clinicians. Canadian Medical Association Journal, v. 172, n. 3, p. 367-379, 2005.

GOMES, A.; PARRA, B. S.; FRANCO, F. O.; BASILE, L.; JOSÉ, L. T.; ROMERO, V. L. Exame da função hepática na medicina veterinária. Revista Científica Eletrônica de Medicina Veterinária, v. 6, n. 11, p. 1-7. 2008.

GOMEZ, D. E.; ALONSO, D. F.; YOSHIJI, H.; THORGEIRSSON, U. P. Tissue inhibitors of metalloproteinases: structure, regulation and biological functions. European Journal of Cell Biology, v. 74, n. 2, p. 111-122, 1997.

GOMEZ-LECHON, M. J.; GUILLEN, I.; PONSODA, X.; FABRA, R.; TRULLENQUE, R.; NAKAMURA, T.; CASTELL, J. V. Cell cycle progression proteins (cyclins), oncogene expression, and signal transduction during the proliferative response of human hepatocytes to hepatocyte growth factor. Hepatology, v. 23, p. 1012-1019, 1996.

GONZÁLEZ-CUEVAS, J.; BUENO-TOPETE, M.; ARMENDARIZ-BORUNDA, J. Urokinase plasminogen activator stimulates function of active forms of stromelysin and gelatinases (MMP-2 and MMP-9) in cirrhotic tissue. Journal of Gastroenterology and Hepatology, v. 21, n. 10, p. 1544-1554, 2006.

GORLA Jr., J. A. Estudo da resposta proliferativa do fígado intacto de ratas à administração de substâncias hepatotróficas. 2001. 52f. Dissertação (Mestrado em Técnica Operatória e Cirurgia Experimental) - Universidade Federal de São Paulo, São Paulo, 2001.

GRIGORESCU, M. Noninvasive biochemical markers of liver fibrosis. Journal of Gastrointestinal and Liver Diseases, v. 15, n. 2, p. 149-159, 2006. 
GU, K.; ZHAO, J-D.; REN, Z-G.; MA, N-Y.; LAI, S-T.; WANG, J.; LIU, J.; JIANG, G-L. A natural process of cirrhosis resolution and deceleration of liver regeneration after thioacetamide withdrawal in a rat model. Molecular Biology Reports, 2010. doi: 10.1007/s11033-010-0281-1. Disponível em: <https://springerlink3.metapress.com>. Acesso em: 15 jan. 2011.

GUERRA, R. R.; TROTTA, M. R.; PARRA, O. M.; AVANZO, J. L.; BATEMAN, A.; ALOIA, T. P. A.; DAGLI, M. L. Z.; HERNANDEZ-BLAZQUEZ, F. J. Modulation of extracellular matrix by nutritional hepatotrophic factors in thioacetamide-induced liver cirrhosis in the rat. Brazilian Journal of Medical and Biological Research, v. 42, n. 11, p. 1027-1034, 2009.

GUNNARSDOTTIR, S. A.; SADIK, R.; SHEV, S.; SIMRÉN, M.; SJÖVALL, H.; STOTZER, P. O.; ABRAHAMSSON, H.; OLSSON, R.; BJÖRNSSON, E. S. Small intestinal motility disturbances and bacterial overgrowth in patients with liver cirrhosis and portal hypertension. The American Journal of Gastroenterology, v. 98, n. 6, p. 1362-1370, 2003.

GUYTON, A. C.; HALL, J. E. Tratado de fisiologia médica. 10. ed. Rio de Janeiro: Guanabara Koogan, 2002. p. 973.

HAGA, S.; TERUI, K.; ZHANG, H. Q.; ENOSAWA, S.; OGAWA, W.; INOUE, H.; OKUYAMA, T.; TAKEDA, K.; AKIRA, S.; OGINO, T.; IRANI, K.; OZAKI, M. STA3 protects against Fas-induced liver injury by redox-dependent and -independent mechanisms. The Journal of Clinical Investigation, v. 112, n. 7, p. 989-998, 2003.

HAHN, E.; WICK, G.; PENCEV, D.; TIMPL, R. Distribution of basement membrane proteins in normal and fibrotic human liver: collagen type IV, laminin and fibronectin. Gut, v. 21, n. 1, p. 36-71, 1980.

HARPER, R. P.; KERINS, C. A.; MCINTOSH, J. E.; SPEARS, R.; BELLINGER, L. L. Modulation of the inflammatory response in the rat TMJ with increasing doses of complete Freund's adjuvant. Osteoarthritis and Cartilage / OARS, Osteoarthritis Research Society, v. 9, n. 7, p. 619-624, 2001.

HASHIMOTO, M.; KOTHARY, P. C.; ECKHAUSER, F. E.; RAPER, S. E. Treatment of cirrhotic rats with epidermal growth factor and insulin accelerates liver DNA synthesis after partial hepatectomy. Journal of Gastroenterology and Hepatology, v. 13, p. 1259-1265, 1998.

HASHMI, A. Z.; HAKIM, W.; KRUGLOV, E. A.; WATANABE, A.; WATKINS, W.; DRANOFF, J. A.; MEHAL, W. Z. Adenosine inhibits cytosolic calcium signals and chemotaxis in hepatic stellate cells. American Journal of Physiology. Gastrointestinal and Liver Physiology, v. 292, n. 1, p. G395-G401, 2007.

HASSE, J. M.; BLUE, L. S.; LIEPA, G. U.; GOLDSTEIN, R. M.; JENNINGS, L. W.; MOR, E.; HUSBERG. B. S.; LEVY, M. F.; GONWA, T. A.; KLINTMALM, G. B. Early enteral nutrition support in patients undergoing liver transplantation. JPEN. Journal of Parenteral and Enteral Nutrition, v. 19, n. 6, p. 437-443, 1995. 
HAUTEKEETE, M. L.; GEERTS, A. The hepatic stellate (Ito) cell: its role in human liver disease. Virchows Archiv: an International Journal of Pathology, v. 430, n. 3, p. 195-207, 1997.

HE, C. S.; WILHELM, S. M.; PENTLAND, A. P.; MARMER, B. L.; GRANT, G. A.; EISEN, A. Z.; GOLDBERG, G. I. Tissue cooperation in a proteolytic cascade activating human interstitial collagenase. Proceedings of the National Academy of Sciences of the United States of America, v. 86, n. 8, p. 2632-2636, 1989.

HE, S-H.; LUO, J-Y.; WANG, Y-P.; WANG, Y-L.; FU, H.; XU, J-L.; ZHAO, G.; LIU, E-Q. Effects of extract from Ginkgo biloba on carbon tetrachloride-induced liver injury in rats. World Journal of Gastroenterology: WJG, v. 12, n. 24, p. 3924-3928, 2006.

HEIDELBAUGH, J. J.; BRUDERLY, M. Cirrhosis and chronic liver failure: Part I. Diagnosis and evaluation. American Family Physician, v. 74, n. 5, p. 756-762, 2006.

HEIDELBAUGH, J. J.; SHERBONDY, M. Cirrhosis and chronic liver failure: Part II. Complications and treatment. American Family Physician, v. 74, n. 5, p. 767-776, 2006.

HENKEL, A. S.; BUCHMAN, A. L. Nutritional support in patients with chronic liver disease. Nature Clinical Practice. Gastroenterology \& Hepatology, v. 3, n. 4, p. 202-209, 2006.

HENMI, A.; UCHIDA, T.; SHIKATA, T. Karyometric analysis of liver cell dysplasia and hepatocellular carcinoma. Evidence against precancerous nature of liver cell dysplasia. Cancer, v. 55, n. 11, p. 2594-2599, 1985.

HERBST, H.; FREY, A.; HEINRICHS, O.; MILANI, S.; BECHSTEIN, W. O.; NEUHAUS, P.; SCHUPPAN, D. Heterogeneity of liver cells expressing procollagen types I and IV in vivo. Histochemistry and Cell Biology, v. 107, n. 5, p. 399-409, 1997.

HIB, J. Di Fiore histologia. Rio de Janeiro: Guanabara Koogan, 2003. p. 513.

HUANG, K. W.; HUANG, Y. C.; TAI, K. F.; CHEN, B. H.; LEE, P. H.; HWANG, L. H. Dual therapeutic effects of interferon-alpha gene therapy in a rat hepatocellular carcinoma model with liver cirrhosis. Molecular Therapy: The Journal of the American Society of Gene Therapy, v. 16, n. 10. p. 1681-1687, 2008.

IIMURO, Y.; NISHIO, T.; MORIMOTO, T.; NITTA, T.; STEFANOVIC, B.; CHOI, S. K.; BRENNER, D. A.; YAMAOKA, Y. 2003. Delivery of matrix metalloproteinase-1 attenuates established liver fibrosis in the rat. Gastroenterology, v. 124, n. 2, p. 445-458, 2003.

IKEDA, K.; WAKAHARA, T.; WANG, Y. Q.; KADOYA, H.; KAWADA, N.; KANEDA, $\mathrm{K}$. In vitro migratory potential of rat quiescent hepatic stellate cells and its augmentation by cell activation. Hepatology, v. 29, n. 6, p. 1760-1767, 1999.

IKEGAMI, T.; SHIMADA, M.; IMURA, S.; ARAKAWA, Y.; NII, A.; MORINE, Y.; KANEMURA, H. Current concept of small-for-size grafts in living donor liver transplantation. Surgery Today, v. 38, n. 11, p. 971-982, 2008. 
INAGAKI, Y.; NEMOTO, T.; KUSHIDA, M.; SHENG, Y.; HIGASHI, K.; IKEDA, K.; KAWADA, N.; SHIRASAKI, F.; TAKEHARA, K.; SUGIYAMA, K.; FUJII, M.; YAMAUCHI, H.; NAKAO, A.; DE CROMBRUGGHE, B.; WATANABE, T.; OKAZAKI, I. Interferon alfa down-regulates collagen gene transcription and suppresses experimental hepatic fibrosis in mice. Hepatology, v. 38, n. 4, p. 890-899, 2003.

INAGAKI, Y.; OKAZAKI, I. Emerging insights into transforming growth factor beta Smad signal in hepatic fibrogenesis. Gut, v. 56, n. 2, p. 284-292, 2007.

IREDALE, J. P. Hepatic stellate cell behavior during resolution of liver injury. Seminars in Liver Disease, v. 21, n. 3, p. 427-436, 2001.

IREDALE, J. P. Models of liver fibrosis: exploring the dynamic nature of inflammation and repair in a solid organ. The Journal of Clinical Investigation, v. 117, n. 3, p. 539-548, 2007.

IREDALE, J. P.; BENYON, R. C.; PICKERING, J.; McCULLEN, M.; NORTHROP, M.; PAWLEY, S.; HOVELL, C.; ARTHUR, M. J. Mechanisms of spontaneous resolution of rat liver fibrosis. Hepatic stellate cell apoptosis and reduced hepatic expression of metalloproteinase inhibitors. The Journal of Clinical Investigation, v. 102, n. 3, p. 538-549, 1998.

IRVING, M. G.; ROLL, J.; HUANG, S.; BISSELL, D. Characterization and culture of sinusoidal endothelium from normal rat liver: lipoprotein uptake and collagen phenotype. Gastroenterology, v. 87, n. 6, p. 1233-1247, 1984.

ISHAK, K.; BAPTISTA, A.; BIANCHI, L.; CALLEA, F.; DE GROOTE, J.; GUDAT, F.; DENK, H.; DESMET, V.; KORB, G.; MACSWEEN, R. N. M.; PHILLIPS, M. J.; PORTMANN, B. G.; POULSEN, H.; SCHEUER, P. J.; SCHMID, M.; THALER, H. Histological grading and staging of chronic hepatitis. Journal of Hepatology, v. 22, n. 6, p. 696-699, 1995.

ISSA, R.; WILLIAMS, E.; TRIM, N.; KENDALL, T.; ARTHUR, M. J.; REICHEN, J.; BENYON, R. C.; IREDALE, J. P. Apoptosis of hepatic stellate cells: involvement in resolution of biliary fibrosis and regulation by soluble growth factors. Gut, v. 48, n. 4, p. 548$557,2001$.

JARNAGIN, W. R.; ROCKEY, D. C.; KOTELIANSKY, V. E.; WANG, S. S.; BISSELL, D. $\mathrm{M}$. Expression of variant fibronectins in wound healing: cellular source and biological activity of the EIIIA segment in rat hepatic fibrogenesis. The Journal of Cell Biology, v. 127, n. 6, Pt. 2, p. 2037-2048, 1994.

JEONG, D.; JANG, J.; LEE, S.; LEE J.; LIM, I.; LEE, M.; LEE, Y. Expression patterns of cell cycle-related proteins in a rat cirrhotic model induced by $\mathrm{CCL}_{4}$ or thioacetamide. Journal of Gastroenterology, v. 36, n. 1, p. 24-32, 2001.

JESUS, R. P.; WAITZBERG, D. L.; CAMPOS, F. G. Regeneração hepática: papel dos fatores de crescimento e nutrientes. Revista da Associação Médica Brasileira, v. 46, n. 3, p. 242$254,2000$. 
JUNQUEIRA, L. C. U.; CARNEIRO, J. Histologia básica. 10. ed. Rio de Janeiro: Guanabara-Koogan, 2004. 488 p.

KAIBORI, M.; KWON, A-H.; NAKAGAWA, M.; WEI, T.; UETSUJI, S.; KAMIYAMA, Y.; OKUMURA, T.; KITAMURA, N. Stimulation of liver regeneration and function after partial hepatectomy in cirrhotic rats by continuos infusion of recombinant human hepatocyte growth factor. Journal of Hepatology, v. 27, n. 2, p. 381-390, 1997.

KALIL, A. N.; SPERB, D.; LICHTENFELS, E. Efeito da pilocarpina na regeneração hepática pós hepatectomia parcial em ratos. Acta Cirúrgica Brasileira, v. 13, n. 4, p. 222-226, 1998.

KAM, I.; LYNCH, S.; SVANAS, G.; TODO, S.; POLIMENO, L.; FRANCAVILLA, A.; PENKROT, R. J.; TAKAYA, S.; ERICZON, B. G.; STARZL, T. E.; VAN THIEL, D. H. Evidence that host size determines liver size: studies in dogs receiving orthotopic liver transplants. Hepatology, v. 7, n. 2, p. 362-366, 1987.

KAPLOWITZ, N.; EBERLE, D.; YAMADA, T. Biochemical tests for liver disease. In: ZAKIM, D.; BOYER, T. D. (Ed.). Hepatology: a textbook of liver disease. Philadelphia: W. B. Saunders Company, 1982. v. 1, p. 583-607.

KATO, A.; BAMBA, H.; SHINOHARA, M.; YAMAUCHI, A.; OTA, S.; KAWAMOTO, C.; YOSHIDA, Y. Relationship between expression of cyclin D1 and impaired liver regeneration observed in fibrotic or cirrhotic rats. Journal of Gastroenterology and Hepatology, v. 20, n. 8, p. 1198-1205, 2005.

KEARNS, P. J.; YOUNG, H.; GARCIA, G.; BLASCHKE, T.; O'HANLON, G.; RINKI, M.; SUCHER, K.; GREGORY, P. Accelerated improvement of alcoholic liver disease with enteral nutrition. Gastroenterology, v. 102, n. 1, p. 200-205, 1992.

KELMAN, Z. PCNA: structure, functions and interactions. Oncogene. v. 14, n. 6, p. 629-640, 1997.

KINNMAN, N.; HULTCRANTZ, R.; BARBU, V.; REY, C.; WENDUM, D.; POUPON, R.; HOUSSET, C. PDGF-mediated chemoattraction of hepatic stellate cells by bile duct segments in cholestatic liver injury. Laboratory Investigation; a Journal of Technical Methods and Pathology, v. 80, n. 5, p. 697-707, 2000.

KLEIN, T.; BISCHOFF, R. Physiology and pathophysiology of matrix metalloproteases. Amino Acids, 2010. doi 10.1007/s00726-010-0689-x. Disponível em: $<$ https://www.springerlink.com>. Acesso em: 15 jan. 2011.

KNÄUPER, V.; LÓPEZ-OTIN, C.; SMITH, B.; KNIGHT, G.; MURPHY, G. Biochemical characterization of human collagenase-3. The Journal of Biological Chemistry, v. 271, n. 3, p. 1544-1550, 1996a.

KNÄUPER, V.; OSTHUES, A.; DECLERCK, Y. A.; LANGLEY, K. E.; BLÄSER, J.; TSCHESCHE, H. Fragmentation of human polymorphonuclear-leucocyte collagenase. The Biochemical Journal, v. 291, Pt. 3, p. 847-854, 1993. 
KNÄUPER, V.; WILL, H.; LÓPEZ-OTIN, C.; SMITH, B.; ATKINSON, S. J.; STANTON, H.; HEMBRY, R. M.; MURPHY, G. Cellular mechanisms for human procollagenase-3 (MMP-13) activation. Evidence that MT1-MMP (MMP-14) and gelatinase A (MMP-2) are able to generate active enzyme. The Journal of Biological Chemistry, v. 271, n. 29, p. 17124-17131, 1996b.

KNODELL, R. G.; ISHAK, K. G.; BLACK, W. C.; CHEN, T. S.; CRAIG, R.; KAPLOWITZ, N.; KIERNAN, T. W.; WOLLMAN, J. Formulation and application of a numerical scoring system for assessing histological activity in asymptomatic chronic active hepatitis.

Hepatology, v. 1, n. 5, p. 431-435, 1981.

KOBAYASHI, H.; SCHMITT, M.; GORETZKI, L.; CHUCHOLOWSKI, N.; CALVETE, J.; KRAMER, M.; GÜNZLER, W. A.; JÄNICKE, F.; GRAEFF, H. Cathepsin B efficiently activates the soluble and the tumor cell receptor-bound form of the proenzyme urokinase-type plasminogen activator (pro-uPA). The Journal of Biological Chemistry, v. 266, n. 8, p. 5147-5152, 1991.

KONDRUP, J.; ALLISON, S. P.; ELIA, M.; VELLAS, B.; PLAUTH, M. Educational and Clinical Practice Committee, European Society of Parenteral and Enteral Nutrition (ESPEN). ESPEN guidelines for nutrition screening 2002. Clinical Nutrition, v. 22, n. 4, p. 415-421, 2003.

KOUNTOUAS, J.; BOURA, P.; LYGIDAKIS, N. J. Liver regeneration after hepatectomy. Hepatogastroenterology, v. 48, p. 556-562, 2001.

KUBOTA, K.; SOEDA, J.; MISAWA, R.; MIHARA, M.; MIWA, S.; ISE, H.; TAKAHASHI, M.; MIYAGAWA, S. Bone marrow-derived cells fuse with hepatic oval cells but are not involved in hepatic tumorigenesis in the choline-deficient ethionine-supplemented diet rat model. Carcionogenesis, v. 29, n. 2, p. 448-454, 2008.

KUMAR, M.; SARIN, S. K. Is cirrhosis of the liver reversible? Indian Journal of Pediatrics, v. 74, n. 4, p. 393-399, 2007.

KWON, A. H.; INADA, Y.; UETSUJI, S.; YAMAMURA, M.; HIOKI, K.; YAMAMOTO, M. Response of fibronectin to liver regeneration after hepatectomy. Hepatology, v. 11, n. 4, p. 593-598, 1990.

LALEMAN, W.; VANDER ELST, I.; ZEEGERS, M.; SERVAES, R.; LIBBRECHT, L.; ROSKAMS, T.; FEVERY, J.; NEVENS, F. A stable model of cirrhotic portal hypertension in rat: thioacetamide revisited. European Journal of Clinical Investigation, v. 36, n. 4, p. 242249, 2006.

LAU, J. Y.; BAIN, V. G.; DAVIES, S. E.; O'GRADY, J. G.; ALBERTI, A.; ALEXANDER, G. J.; WILLIAMS, R. High-level expression of hepatitis B viral antigens in fibrosing cholestatic hepatitis. Gastroenterology, v. 102, n. 3, p. 956-962, 1992.

LE COUTEUR, D. G.; WARREN, A.; COGGER, V. C.; SMEDSRØD, B.; SØRENSEN, K. K.; DE CABO, R.; FRASER, R.; MCCUSKEY, R. S. Old age and the hepatic sinusoid. Anatomical Record, v. 291, n. 6, p. 672-683, 2008. 
LEBMAN, D. A.; EDMISTON, J. S. The role of TGF-beta in growth, differentiation, and maturation of B lymphocytes. Microbes and Infection / Institut Pasteur, v. 1, n. 15, p. 1297-1304, 1999.

LECOUTER, J.; MORITZ, D. R.; LI, B.; PHILlIPS, G. L.; LIANG, X. H.; GERBER, H. P.; HILLAN, K. J.; FERRARA, N. Angiogenesis-independent endothelial protection of liver: role of VEGFR-1. Science, v. 299, n. 5608, p. 890-893, 2003.

LEE, K. S.; BUCK, M.; HOUGLUM, K.; CHOJKIER, M. Activation of hepatic stellate cells by TGF alpha collagen type I is mediated by oxidative stress through c-myb expression. The Journal of Clinical Investigation, v. 96, n. 5, p. 2461-2468, 1995.

LEE, R. F.; GLENN, T. K.; LEE, S. S. Cardiac dysfunction in cirrhosis. Best Practice and Research Clinical Gastroenterology, v. 21, n. 1, p. 125-140, 2007.

LEE, S. L. Activation of hepatocyte growth factor and urokinase/plasminogen activator by matriptase, an epithelial membrane serine protease. The Journal of biological chemistry, $v$. 36, p. 720-725, 2000.

LESSA, I. Cirrhosis of the liver in Brazil: mortality and productive years of life lost prematurely. Revista Panamericana de Salud Pública, v, 1, n. 2, p. 125-132, 1997.

LETTERIO, J. J.; ROBERTS, A. B. Regulation of immune responses by TGF-beta. Annual Review of Immunology, v. 16, p. 137-161, 1998.

LEYLAND, H.; GENTRY, J.; ARTHUR, M. J.; BENYON, R. C. The plasminogenactivating system in hepatic stellate cells. Hepatology, v. 24, n. 5, p. 1172-1178, 1996.

LI, X.; BENJAMIN, I. S.; ALEXANDER, B. Reproducible production of thioacetamideinduced macronodular cirrhosis in the rat with no mortality. Journal of Hepatology, v. 36, n. 4, p. 488-493, 2002.

LI, Y. R.; WEI, L. Mechanism of transforming growth factor beta/Smad signaling and the relationship between its transduction and liver fibrosis. Zhonghua Gan Zang Bing Za Zhi, v. 13, n. 6, p. 476-478, 2005.

LIMA, T. T. Cirrose hepática induzida por tioacetamida: estudo do modelo por injeção intraperitoneal a longo prazo em ratas Wistar. 2008. 140 f. Dissertação (Mestrado) Faculdade de Medicina Veterinária e Zootecnia, Universidade de São Paulo, São Paulo, 2008.

LIN, Y.; XIE, W. F.; CHEN, Y. X.; ZHANG, X.; ZENG, X.; QIANG, H.; CHEN, W. Z.; YANG, X. J.; HAN, Z. G.; ZHANG, Z. B. Treatment of experimental hepatic fibrosis by combinational delivery of urokinase-type plasminogen activator and hepatocyte growth factor genes. Liver International: Official Journal of the International Association for the Study of the Liver. v. 25, n. 4, p. 796-807, 2005.

LIVAK, K. J.; SCHMITTGEN, T. D. Analysis of relative gene expression data using realtime quantitative PCR and the 2(-Delta Delta C(T)) Method. Methods, v. 25, n. 4, p. 402-408, 2001. 
LOWES, K. N.; BRENNAN, B. A.; YEOH, G. C.; OLYNYK, J. K. Oval cell numbers in human chronic liver diseases are directly related to disease severity. American Journal of Pathology, v. 154, n. 2, p. 537-541, 1999.

LUO, D. Z.; VERMIJLEN, D.; AHISHALI, B.; TRIANTIS, V.; PLAKOUTSI, G.; BRAET, F.; VANDERKERKEN, K.; WISSE, E. On the cell biology of pit cells, the liver-specific NK cells. World Journal of Gastroenterology: WJG, v. 6, n. 1, p. 1-11, 2000.

MACLACHLAN, N. J.; CULLEN, J. M. Fígado, sistema biliar e pâncreas In: CARLTON, W. W.; McGAVIN, M. D. Patologia veterinária especial. 2. ed. Porto Alegre: Artmed, 1998. p. 95-96.

MAGA, G.; HUBSCHER, U. Proliferating cell nuclear antigen (PCNA): a dancer with many partners. Journal of Cell Science, v. 116, Pt. 15, p. 3051-3060, 2003.

MAHER, J. J.; MCGUIRE, R. F. Extracellular matrix gene expression increases preferentially in rat lipocytes and in sinusoidal endothelial cells during hepatic fibrosis in vivo. The Journal of Clinical Investigation, v. 86, n. 5, p. 1641-1648, 1990.

MAIO, R.; DICHI, J. B.; BURINI, R. C. Conseqüências nutricionais das alterações metabólicas dos macronutrientes na doença hepática crônica. Arquivos de Gastroenterologia, v. 37, n.1, p. 52-57, 2000.

MANNING, D. S.; AFDHAL, N. H. Diagnosis and quantitation of fibrosis.

Gastroenterology, v. 134, n. 6, p. 1670-1681, 2008.

MARCHENKO, N. D.; MARCHENKO, G. N.; WEINREB, R. N.; LINDSEY, J. D.; KYSHTOOBAYEVA, A.; CRAWFORD, H. C.; STRONGIN, A. Y. Beta-catenin regulates the gene of MMP-26, a novel metalloproteinase expressed both in carcinomas and normal epithelial cells. The International Journal of Biochemistry \& Cell Biology, v. 36, n. 5, p. 942-956, 2004.

MARRA, F.; DEFRANCO, R.; GRAPPONE, C.; MILANI, S.; PINZANI, M.; PELLEGRINI, G.; LAFFI, G.; GENTILINI, P. Expression of the thrombin receptor inhumanliver: upregulation during acute and chronic injury. Hepatology, v. 27, n. 2, p. 462-471, 1998.

MARRA, F.; GRANDALIANO, G.; VALENTE, A. J.; ABBOUD, H. E. Thrombin stimulates proliferation of liver fat-storing cells and expression of monocyte chemotactic protein-1: potential role in liver injury. Hepatology, v. 22, n. 3, p. 780-787, 1995.

MARRA, F.; ROMANELLI, R. G.; GIANNINI, C.; FAILLI, P.; PASTACALDI, S.; ARRIGHI, M. C.; PINZANI, M.; LAFFI, G.; MONTALTO, P.; GENTILINI, P. Monocyte chemotactic protein-1 as a chemoattractant for human hepatic stellate cells. Hepatology, v. 29, n. 1, p. 140-148, 1999.

MASSAGUÉ, J. G1 cell-cycle control and cancer. Nature, v. 432, n. 7015, p. 298-306, 2004.

MASUMI, S.; MORIYAMA, M.; KANNAN, Y.; OHTA, M.; KOSHITANI, O.;

SAWAMOTO, O.; SUGANO, T. Changes in hepatic nitrogen metabolism in isolated 
perfused liver during the development of thioacetamide-induced cirrhosis in rats. Toxicology, v. 135, n. 1, p. 21-31, 1999.

MATHEWS, M. B.; BERNSTEIN, R. M.; FRANZA, B. R JR.; GARRELS, J. I. Identity of the proliferating cell nuclear antigen and cyclin. Nature, v. 309, n. 5966, p. 374-376, 1984.

MATSUDA, Y.; MATSUMOTO, K.; ICHIDA, T.; ASAKURA, H.; KOMORIYA, Y.; NISHIAMA, E.; NAKAMURA, T. Preventive and therapeutic effects in rats of hepatocyte growth factor infusion on liver fibrosis/cirrhosis. Hepatology, v. 26, n. 1, p. 81-89, 1997.

MATSUDA, Y.; MATSUMOTO, K.; ICHIDA, T.; NAKAMURA, T. Hepatocyte growth factor suppresses the onset of liver cirrhosis and abrogates lethal hepatic disfunction in rats. Journal Biochemical, v. 118, n. 3, p. 643-649, 1995.

MEHTA, R. The potential for use of cell proliferation and oncogene expression as intermediate markers during liver carcinogenesis. Cancer Letters, v. 93, n. 1, p. 85-102, 1995.

MELTON, A. C.; YEE, H. F. Hepatic stellate cell protrusions couple platelet-derived growth factor-BB to chemotaxis. Hepatology, v. 45, n. 6, p. 1446-1453, 2007.

MEURER, S. K.; TIHAA, L.; LAHME, B.; GRESSNER, A. M.; WEISKIRCHEN, R. Identification of endoglin in rat hepatic stellate cells: new insights into transforming growth factor beta receptor signaling. The Journal of Biological Chemistry, v. 280, n. 4, p. 30783087, 2005.

MICHALOPOULOS, G. K.; DEFRANCES, M. C. Liver regeneration. Science, v. 276, n. 5309, p. 60-65, 1997.

MILANI, A.; ZACCARIA, R.; BOMBARDIERI, G.; GASBARRINI, A.; POLA, P. Cirrhotic cardiomyopathy. Digestive and Liver Disease, v. 39, n. 6, p. 507-515, 2007.

MIYACHI, K.; FRITZLER, M. J.; TAN, E. M. Journal of Immunology, v. 121, n. 6, p. 2228-2234, 1978.

MOREIRA, E.; FONTANA, L.; TORRES, M. I.; FERNÁNDEZ, I.; RÍOS, A.; SÁNCHEZ DE MEDINA, F.; GIL, A. Dietary long-chain polyunsaturated fatty acids influence the recovery of thioacetamide-induced liver cirrhosis in rats. JPEN. Journal of Parenteral and Enteral Nutrition, v. 19, n. 6, p. 461-469, 1995.

MORSIANI, E.; GORINI, P.; FOGLI, L.; SANTINI, A. Attualita in tema di trofismo e rigenerazione epatica: Update on the subject of trophism and liver regeneration. Minerva Medicine, v. 75, n. 20, p. 1179-1183, 1984.

MÜLLER, M. J.; BÖKER, K. H.; SELBERG, O. Are patients with liver cirrhosis hypermetabolic? Clinical Nutrition, v. 13, n. 3, p. 131-144, 1994.

MÜLLER, M. J.; BÖTTCHER, J.; SELBERG, O.; WESELMANN, S.; BÖKER, K. H.; SCHWARZE, M.; VON ZUR MÜHHLEN, A.; MANNS, M. P. Hypermetabolism in clinically 
stable patients with liver cirrhosis. The American Journal of Clinical Nutrition, v. 69, n. 6, p. 1194-1201, 1999.

MUÑOZ TORRES, E.; PAZ BOUZA, J. I.; LÓPEZ BRAVO, A.; ABAD HERNÁNDEZ, M. M.; CARRASCAL MARINO, E. Experimental thioacetamide-induced cirrosis of the liver. Histology and Histopathology, v. 6, n. 1, p. 95-100, 1991.

MURIEL, P.; ESCOBAR, Y. Kupffer cells are responsible for liver cirrhosis induced by carbon tetrachloride. Journal of Applied Toxicology, v. 23, n. 2, p. 103-108, 2003.

MURPHY, G.; MCALPINE, C. G.; POLL, C. T.; REYNOLDS, J. J. Purification and characterization of a bone metalloproteinase that degrades gelatin and types IV and V collagen. Biochimica et Biophysica Acta, v. 831, n. 1, p. 49-58, 1985.

MURPHY, G.; NAGASE, H. Review. Progress in matrix metalloproteinase research. Molecular Aspects of Medicine, v. 29, n. 5, p. 290-308, 2008.

MURPHY, G.; SEGAIN, J. P.; O'SHEA, M.; COCKETT, M.; IOANNOU, C.; LEFEBVRE, O.; CHAMBON, P.; BASSET, P. The 28-kDa N-terminal domain of mouse stromelysin-3 has the general properties of a weak metalloproteinase. The Journal of Biological Chemistry, $v$. 268, n. 21, p. 15435-15441, 1993.

MYRONOVYCH, A.; MURATA, S.; CHIBA, M.; MATSUO, R.; IKEDA, O.; WATANABE, M.; HISAKURA, K.; NAKANO, Y.; KOHNO, K.; KAWASAKI, T.; HASHIMOTO, I.; SHIBASAKI, Y.; YASUE, H.; OHKOHCHI, N. Role of platelets on liver regeneration after $90 \%$ hepatectomy in mice. Journal of Hepatology, v. 49, n. 3, p. 363-372, 2008.

NAKAJIMA, M.; IRIMURA, T.; NICOLSON, G. L. Heparanases and tumor metastasis. Journal of Cellular Biochemistry, v. 36, n. 2, p. 157-167, 1988.

NAKATANI, K.; KANEDA, K.; SEKI, S.; NAKAJIMA, Y. Pit cells as liver-associated natural killer cells: morphology and function. Medical Electron Microscopy: Official Journal of the Clinical Electron Microscopy Society of Japan, v. 37, n. 1, p. 29-36, 2004.

NEUBAUER, K.; KRÜGER, M.; QUONDAMATTEO, F.; KNITTEL, T.; SAILE, B.; RAMADORI, G. Transforming growth factor-beta1 stimulates the synthesis of basement membrane proteind laminin, collagen type IV and entactin in rat liver sinusoidal endothelial cells. Journal of Hepatology, v. 31, n. 4, p. 692-702, 1999.

NIHIKAWA, Y.; WANG, M.; CARR, B. I. Changes in TGF-beta receptor of rat hepatocytes during primary culture and liver regeneration: Increased expression of TGF- beta receptors associated with increased sensitivity to TGFbeta mediated growth inhibition. Journal of Cellular Physiology, v. 176, n. 3, p. 61-623, 1998. 
NOGUCHI, A.; REIS, J. M. C.; DIAS, C. S.; EPAMINONDAS, W. A.; AZEVEDO, P. S. R.; BRITO, M. V. H. Serum levels of aminotransferases, bilirrubins and gamaglutamyltranspeptidase after copaiba oil administration in rats. Acta Cirurgica Brasileira, v. 17, n. 2, p. 130-134, 2002.

NOVO, E.; MARRA, F.; ZAMARA, E.; VALFRE DI BONZO, L.; CALIGIURI, A.; CANNITO, S.; ANTONACI, C.; COLOMBATTO, S.; PINZANI, M.; PAROLA, M. Dose dependent and divergent effects of superoxide anion on cell death, proliferation, and migration of activated human hepatic stellate cells. Gut, v. 55, n. 1, p. 90-97, 2006.

OE, S.; FUKUNAKA, Y.; HIROSE, T.; YAMAOKA, Y.; TABATA, Y. A trial on regeneration therapy of rat liver cirrosis by controlled release of hepatocyte growth factor. Journal of Controlled Release, v. 88, n. 2, p. 193-200, 2003.

OHUCHI, E.; IMAI, K.; FUJII, Y.; SATO, H.; SEIKI, M.; OKADA, Y. Membrane type 1 matrix metalloproteinase digests interstitial collagens and other extracellular matrix macromolecules. The Journal of Biological Chemistry, v. 272, n. 4, p. 2446-2451, 1997.

OKAZAKI, I.; WATANABE, T.; HOZAWA, S.; NIIOKA, M.; ARAI, M.; MARUYAMA, K. Reversibility of hepatic fibrosis: from the first report of collagenase in the liver to the possibility of gene therapy for recovery. The Keio Journal of Medicine, v. 50, n. 2. p. 58-65, 2001.

OLSON, D.; PÖLLÄNEN, J.; HØYER-HANSEN, G.; RØNNE, E.; SAKAGUCHI, K.; WUN, T. C.; APPELLA, E.; DANØ, K.; BLASI, F. Internalization of the urokinaseplasminogen activator inhibitor type-1 complex is mediated by the urokinase receptor. The Journal of Biological Chemistry, v. 267, n. 13, p. 9129-9133, 1992.

OZDOGAN, M.; ERSOY, E.; DUNDAR, K.; ALBAYRAK, L.; DEVAY, S.; GUNDOGDU, $H$. Beneficial effect of hyperbaric oxygenation on liver regeneration in cirrhosis. Journal of Surgical Research, v. 129, p. 260-264, 2005.

OZER, J.; RATNER, M.; SHAW, M.; BAILEY, W.; SCHOMAKER, S. The current state of serum biomarkers of hepatotoxicity. Toxicology, v. 245, n. 3, p. 194-205, 2008.

PAKU, S.; SCHNUR, J.; NAGY, P.; THORGEIRSSON, S. S. Origin and structural evolution of the early proliferating oval cells in rat liver. The American Journal of Pathology, v. 158, n. 4, p. 1313-1323, 2001.

PALMA, D. T.; FALLON, M. B. The hepatopulmonary syndrome. Journal of Hepatology, v. 45, n. 4, p. 617-625, 2006.

PARISH, C. R.; FREEMAN, C.; HULETT, M. D. Heparanase: a key enzyme involved in cell invasion. Biochimica et Biophysica Acta, v. 1471, n. 3, p. M99-M108, 2001.

PARKS, W. C.; WILSON, C. L.; LÓPEZ-BOADO, Y. S. Matrix metalloproteinases as modulators of inflammation and innate immunity. Nature Reviews. Immunology, v. 4, n. 8, p. 617-629, 2004. 
PAROLIN, M. B.; ZAINA, F. E.; LOPES, R. W. Terapia nutricional no transplante hepático. Arquivos de Gastroenterologia, v. 39, n. 2, p. 114-122, 2002.

PARRA, O. M. Métodos de estímulo da regeneração do fígado e perspectivas no tratamento da cirrose hepática. Revisão, comentários e contribuição. 1982. $219 \mathrm{f}$. Dissertação (Mestrado em Clínica Cirúrgica)-Faculdade de Medicina, Universidade de São Paulo, São Paulo, 1982.

PARRA, O. M.; HERNANDEZ-BLAZQUEZ, F. J.; SILVA, J. R. M. C.; SOUZA E SILVA, R. A. P.; SAAD, W. A.; SAAD JR, W. A. Behavior of collagen extracellular liver matrix during regenerative growth after partial hepatectomy or after stimulation by exogenous hepatotrophic factors. Study in rats. Arquivos de Gastroenterologia, v. 33, n. 4, p. 212-216, 1996.

PARRA, O. M.; HERNANDEZ-BLAZQUEZ, F. J.; SOUZA E SILVA, R. A. P.; SILVA, J. R. M. C.; PEDUTO, L.; SOARES, M. M.; SAAD, W. A.; SAAD Jr, W. A. Reduction of liver mass due to malnutrition in rats. Correlation with emaciation of animals and size of organs not inserted in the portal system. São Paulo Medical Journal = Revista Paulista de Medicina, v. 113, n. 3, p. 903-909, 1995a.

PARRA, O. M.; SAAD, W. A.; FERRAZ-NETO, J. B-H. E.; FERRI, S.; SOUZA E SILVA, R. A. P.; DAL COLLETTO, G. M. D.; SAAD Jr, W. A. Additional growth of an intact liver induced by exogenous hepatotrophic factors. A study in rats. ABCD - Arquivos Brasileiros de Cirurgia Digestiva, v. 7, n. 4, p. 64-68, 1992.

PARRA, O. M.; SAAD, W. A.; SOUSA E SILVA, R. A. P.; HERNANDEZ-BLAZQUEZ, F. J.; PEDUTO, L.; FERRAZ-NETO, J. B-H. E.; SAAD Jr, W. A. Stimulation of intact rat liver by exogenous hepatotrophic factors with additional growth of its mass. Acta Cirúrgica Brasileira, v. 9, n. 1, p. 7-11, 1994.

PARRA, O. M.; SOUZA E SILVA, R. A. P.; SILVA, J. R. M. C.; HERNANDEZBLAZQUEZ, F. J.; PEDUTO, L.; SAAD, W. A.; SAAD Jr, W. A. Enhancement of liver size by stimulation of intact rat liver with exogenous hepatotrophic factors. São Paulo Medical Journal = Revista Paulista de Medicina, v. 113, n. 4, p. 941-947, 1995b.

PATSENKER, E.; POPOV, Y.; STICKEL, F.; SCHNEIDER, V.; LEDERMANN, M.; SÄGESSER, H.; NIEDOBITEK, G.; GOODMAN, S. L.; SCHUPPAN, D. Pharmacological inhibition of integrin alphavbeta3 aggravates experimental liver fibrosis and suppresses hepatic angiogenesis. Hepatology, v. 50, n. 5, p. 1501-1511, 2009.

PATTERSON, M. L.; ATKINSON, S. J.; KNÄUPER, V.; MURPHY, G. Specific collagenolysis by gelatinase A, MMP-2, is determined by the hemopexin domain and not the fibronectin-like domain. FEBS Letters, v. 503, n. 2-3, p. 158-162, 2001.

PEI, D.; WEISS, S. J. Furin-dependent intracellular activation of the human stromelysin-3 zymogen. Nature, v. 375, n. 6528, p. 244-247, 1995.

PEREIRA, H. M.; HERNANDEZ-BLAZQUEZ, F. J.; PARRA, O. M.; COGLIATI, B.; COSTA, W. P. Quantificação do tecido colágeno em fígados com fibrose induzida em ratas 
(Rattus norvegicus albinus) tratadas com fatores hepatotróficos exógenos. Arquivos de Ciências Veterinárias e Zoologia da Unipar, v. 6, p. 196-217, 2003.

PETERSEN, B. E.; ZAJAC, V. F.; MICHALOPOULOS, G. K. Hepatic oval cell activation in response to injury following chemically induced periportal or pericentral damage in rats. Hepatology, v. 27, n. 4, p. 1030-1038, 1998.

PETERSEN, L. C.; LUND, L. R.; NIELSEN L. S.; DANØ, K.; SKRIVER, L. One-chain urokinase-type plasminogen activator from human sarcoma cells is a proenzyme with little or no intrinsic activity. The Journal of Biological Chemistry, v. 263, n. 23, p. 11189-11195, 1988.

PINES, M.; KNOPOV, V.; GENINA, O.; LAVELIN, I.; NAGLER, A. Halofuginone, a specific inhibitor of collagen type I synthesis, prevents dimethylnitrosamine-induced liver cirrhosis. Journal of Hepatology, v. 27, n. 2, p. 391-398, 1997.

PINZANI, M. PDGF and signal transduction in hepatic stellate cells. Frontiers in Bioscience: a Journal and Virtual Library, v. 7, d1720-d1726, 2002.

PINZANI, M.; MARRA, F.; CARLONI, V. Signal transduction in hepatic stellate cells. Liver, v. 18, n. 1, p. 2-13, 1998.

PIROVINO, M.; LINDER, R.; BOSS, C.; KÖCHLI, H. P.; MAHLER, F. Cutaneous spider nevi in liver cirrhosis: capillary microscopical and hormonal investigations. Klinische Wochenschrift, v. 66, n. 7, p. 298-302, 1988.

PLAUTH, M.; ROSKE, A. E.; ROMANIUK, P.; ROTH, E.; ZIEBIG, R.; LOCHS, H. Postfeeding hyperammonaemia with transjugular intrahepatic portosystemic shunt and liver cirrhosis: role of small intestinal ammonia release and route of nutrient administration. Gut, v. 46, n. 6 , p. $849-855,2000$.

PLOW, E. F.; MILES, L. A. Plasminogen receptors in the mediation of pericellular proteolysis. Cell Differentiation and Development: the Official Journal of the International Society of Developmental Biologists, v. 32, n. 3, p. 293-298, 1990.

POPPER, H. Pathologic aspects of cirrhosis. The American Journal of Pathology, v. 87, p. 228-264, 1977.

POTTEN, C. S.; LOFFLER, M. Stem cells- attributes, cycles, spirals, pitfalls and uncertain. Development, v. 110, p. 1001-1020, 1990.

POYNARD, T.; BEDOSSA, P.; OPOLON, P. Natural history of liver fibrosis progression in patients with chronic hepatitis C. The OBSVIRC, METAVIR, CLINIVIR, and DOSVIRC groups. Lancet, v. 349, n. 9055, p. 825-832, 1997.

PRELICH, G.; TAN, C. K.; KOSTURA, M.; MATHEWS, M. B.; SO, A. G.; DOWNEY, K. M.; STILLMAN, B. Functional identity of proliferating cell nuclear antigen and a DNA polymerase-delta auxiliary protein. Nature, v. 326, n. 6112, n. 517-520, 1987. 
QIN, B. Y.; LAM, S. S.; CORREIA, J. J.; LIN, K. Smad3 allostery links TGF-beta receptor kinase activation to transcriptional control. Genes \& Development, v. 16, n. 15, p. 19501963, 2002.

RACHFAL, A. W.; BRIGSTOCK, D. R. Connective tissue growth factor (CTGF/CCN2) in hepatic fibrosis. Hepatology Research: the Official Journal of the Japan Society of Hepatology, v. 26, n. 1, p. 1-9, 2003.

RAMADORI, G. The stellate cell (Ito-cell, fat-storing cell, lipocyte, perisinusoidal cell) of the liver. New insights into pathophysiology of an intriguing cell. Virchous Archiv. B, Cell Pathology Including Molecular Pathology, v. 61, n. 3, p. 147-158, 1991.

RAMADORI, G.; VEIT, T.; SCHWÖGLER, S.; DIENES, H. P.; KNITTEL, T.; RIEDER, H.; MEYER ZUM BÜSCHENFELDE, K. H. Expression of the gene of the alpha-smooth muscleactin isoform in rat liver and in rat fat-storing (ITO) cells. Virchows Archiv. B, Cell Pathology Including Molecular Pathology, v. 59, n. 6, p. 349-357, 1990.

RAMAIAH, S. K.; APTE, U.; MEHENDALE, H. M. Cytochrome P4502E1 induction increases thioacetamide liver injury in diet-restricted rats. Drug Metabolism and

Disposition: The Biological Fate of Chemicals, v. 29, n. 8, p. 1088-1095, 2001.

RAMALHO, F. S.; RAMALHO, L. N. Z.; CASTRO E SILVA JÚNIOR, O.; ZUCOLOTO, S.; CORRÊA, F. M. A. Angiotensin-converting enzyme inhibition by lisinopril enhances liver regeneration in rats. Brazilian Journal of Medical and Biological Research, v. 34, p. 125$127,2001$.

RAO, J. Molecular mechanisms of glioma invasiveness: the role of proteases. Nature Reviews. Cancer, v. 3, p. 489-501, 2003.

RAPPAPORT, A. M.; MCPHEE, P. J.; FISHER, M. M.; PHILLIPS, M. J. The scarring of the liver acini (cirrhosis). Tridimensional and microcirculatory considerations. Virchows Archiv: an International Journal of Pathology, v. 402, p. 107-137, 1983.

REYNAERT, H.; THOMPSON, M. G.; THOMAS, T.; GEERTS, A. Hepatic stellate cells: role in microcirculation and pathophysiology of portal hypertension. Gut, v. 50, n. 4, p. 571$581,2002$.

RIEDER, H.; RAMADORI, G.; DIENES, H. P.; MEYER ZUM BÜSCHENFELDE, K. H. Sinusoidal endothelial cells from guinea pigliver synthesize and secrete cellular fibronectin in vitro. Hepatology, v. 7, n. 5, p. 856-864, 1987.

RIO TINTO, R.; REDONDO, I.; DELGADO, C.; MARTINS, J.; MARTINS NEVES, M. Hepato-colangiocarcinoma: a propósito de um caso clínico. Jornal Português de Gastrenterologia, v. 10, p. 160-163, 2003.

ROBBINS, S. L.; COTRAN, R. S.; KUMAR, V. Patologia estrutural e funcional. 2.ed. Rio de Janeiro: Guanabara Koogan, 1996. 605 p.

ROBERTS, M. S.; ANGUS, D. C.; BRYCE, C. L.; VALENTA, Z.; WEISSFELD, L. Survival after liver transplantation in the United States: a disease-specifi c analysis of the 
UNOS database. Liver Transplantation: Official Publication of the American Association for the Study of Liver Diseases and the International Liver Transplantation Society, v. 10, n. 7, p. 886-897, 2004.

ROCKEY, D. C. Cellular pathophysiology of portal hypertension and prospects for management with gene therapy. Clinics in Liver Disease, v. 5, n. 3, p. 851-865, 2001a.

ROCKEY, D. C. Hepatic blood flow regulation by stellate cells in normal and injured liver. Seminars in Liver Disease, v. 21, n. 3, p. 337-349, 2001 b.

ROCKEY, D. C. Vascular mediators in the injured liver. Hepatology, v. 37, n. 1, p. 4-12, 2003.

ROCKEY, D. C.; BOYLES, J. K.; GABBIANI, G.; FRIEDMAN, S. L. Rat hepatic lipocytes express smooth muscle actin upon activation in vivo and in culture. Journal of Submicroscopic Cytology and Pathology, v. 24, n. 2, p. 193-203, 1992.

ROJKIND, M.; GIAMBRONE, M. A.; BIEMPICA, L. Collagen types in normal and cirrhotic liver. Gastroenterology, v. 76, n. 4, p. 710-719, 1979.

ROMITI, A.; MERLI, M.; MARTORANO, M.; PARRILLI, G.; MARTINO, F.; RIGGIO, O.; TRUSCELLI, A.; CAPOCACCIA, L.; BUDILLON, G. Malabsorption and nutritional abnormalities in patients with liver cirrhosis. The Italian Journal of Gastroenterology, v. 22, n. 3, p. 118-123, 1990.

ROSEMBAUM, J.; BLAZEJEWESKI, S. Regulation of Ito cell proliferation by soluble factors. Journal of Hepatology, v.22, n. 2, p. 65-70, 1995. Supllement 1.

ROSMORDUC, O.; WENDUM, D.; CORPECHOT, C.; GALY, B.; SEBBAGH, N.; RALEIGH, J.; HOUSSET, C.; POUPON, R. Hepatocellular hypoxia-induced vascular endothelial growth factor expression and angiogenesis in experimental biliary cirrhosis. The American Journal of Pathology, v. 155, p. 1065-1073, 1999.

ROTHUIZEN, J. Canine chronic liver disease: where are we now? Four pointers for future research. The Veterinary Journal, v. 167, n. 3, p. 219, 2004.

ROUILLER, C. The liver. London: Academic Press, 1964. v. 2, p. 674.

SAAD, W. A. Observações morfológicas, auto-radiográficas, morfométricas, histoquímica e bioquímica sobre a regeneração do fígado cirrótico de rato, induzida pela dupla hepatectomia parcial. 1975. 75 f. Tese (Doutorado em Clínica Cirúrgica) - Faculdade de Medicina, Universidade de São Paulo, São Paulo, 1975.

SAAD, W. A. Observações morfológicas, auto-radiográficas, morfométricas, histoquímica e bioquímica sobre a regeneração do fígado cirrótico de rato, induzida pela hepatectomia parcial. 1972. 46 f. Dissertação (Mestrado em Clínica Cirúrgica) - Faculdade de Medicina, Universidade de São Paulo, São Paulo, 1972. 
SAILE, B.; MATTHES, N.; KNITTEL, T.; RAMADORI, G. Transforming growth factor beta and tumor necrosis factor alpha inhibit both apoptosis and proliferation of activated rat hepatic stellate cells. Hepatology, v. 30, n. 1, p. 196-202, 1999.

SALGADO, S.; GARCIA, J.; VERA, J.; SILLER, F.; BUENO, M.; MIRANDA, A.; SEGURA, A.; GRIJALVA, G.; SEGURA, J.; OROZCO, H.; HERNANDEZ-PANDO, R.; FAFUTIS, M.; AGUILAR, L. K.; AGUILAR-CORDOVA, E.; ARMENDARIZ-BORUNDA, $\mathrm{J}$. Liver cirrhosis is reverted by urokinase-type plasminogen activador gene therapy.

Molecular Therapy, v. 2, n. 6, p. 545-551, 2000.

SANTAMARIA; D.; ORTEGA, S. Cyclins and CDKS in development and cancer: lessons from genetically modified mice. Frontiers in Bioscience: A Journal and Virtual Library, v. 1, n. 11, p. 1164-1188, 2006.

SANZ, N.; DÍEZ-FERNÁNDEZ, C.; FERNÁNDEZ-SIMÓN, L.; ALVAREZ, A.;

CASCALES, M. Necrogenic and regenerative responses of liver of newly weaned rats against a sublethal dose of thioacetamide. Biochimica et Biophisica Acta - Protein Structure and Molecular Enzymology, v. 1384, n. 1, p. 66-78, 1998.

SATO, Y.; MURASE, K.; KATO, J.; KOBUNE, M.; SATO, T.; KAWANO, Y.; TAKIMOTO, R.; TAKADA, K.; MIYANISHI, K.; MATSUNAGA, T.; TAKAYAMA, T.; NIITSU, Y. Resolution of liver cirrhosis using vitamin A-coupled liposomes to deliver siRNA against a collagen-specific chaperone. Nature Biotechnology, v. 26, n. 4. p. 431-442, 2008.

SCHAEFER, B.; RIVAS-ESTILLA, A. M.; MERAZ-CRUZ, N.; REYES-ROMERO, M. A.; HERNANDEZ-NAZARA, Z. H.; DOMINGUEZ-ROSALES, J. A.; SCHUPPAN, D.; GREENWEL, P.; ROJKIND, M. Reciprocal modulation of matrix metalloproteinase-13 and type I collagen genes in rat hepatic stellate cells. The American Journal of Pathology, v. 162, n. 6, p. 1771-1780, 2003.

SCHINDHELM, R. K.; DIAMANT, M.; DEKKER, J. M.; TUSHUIZEN, M. E.; TEERLINK, T.; HEINE, R. J. Alanine aminotransferase as a marker of non-alcoholic fatty liver disease in relation to type 2 diabetes mellitus and cardiovascular disease. Diabetes/Metabolism Research and Reviews, v. 22, n. 6, p. 437-443, 2006.

SCHUPPAN, D.; AFDHAL, N. H. Liver cirrhosis, Lancet, v. 371, n. 9615, p. 838-851, 2008.

SCHUPPAN, D.; CHO, J. J.; JIA, J. D.; HAHN, E. G. Interplay of matrix and myofibroblasts during hepatic fibrogenesis. Current Topics in Pathology. Ergebnisse der Pathologie, v. 93, p. 205-218, 1999.

SCHUPPAN, D.; KREBS, A.; BAUER, M.; HAHN, E. G. Hepatitis C and liver fibrosis. Cell Death and Differentiation, v. 10, p. S59-67, 2003. Supllement 1.

SCHUPPAN, D.; RUEHL, M.; SOMASUNDARAM, R.; HAHN, E. G. Matrix as a modulator of hepatic fibrogenesis. Seminars in Liver Disease, v. 21, n. 3, p. 351-372, 2001.

SCHWOEGLER, S.; NEUBAUER, K.; KNITTEL, T.; CHUNG, A.; RAMADORI, G. Entactin gene expression in normal and fibrotic rat liver and in rat liver cells. Laboratory 
Investigation: a Journal of Technical Methods and Pathology, v. 70, n. 4, p. 525-536, 1994.

SEIFFERT, D.; MIMURO, J.; SCHLEEF, R. R.; LOSKUTOFF, D. J. Interactions between type I plasminogen activator inhibitor, extracellular matrix and vitronectin. Cell Differentiation and Development: the Official Journal of the International Society of Developmental Biologists, v. 32, n. 3, p. 287-292, 1990.

SELL, S. Heterogeneity and plasticity of hepatocyte lineage cells. Hepatology, v. 33, n. 3, p. 738-750, 2001.

SEVELIUS, E. Diagnosis and prognosis of chronic hepatitis and cirrhosis in dogs. The Journal of Small Animal Practice, v. 36, n. 12, p. 521-528, 1995.

SEYER, J. M.; HUTCHESON, E. T.; KANG, A. H. Collagen polymorphism in normal and cirrhotic human liver. The Journal of Clinical Investigation, v. 59, n. 2, p. 241-248, 1977.

SOBREVALS, L.; RODRIGUEZ, C.; ROMERO-TREVEJO, J. L.; GONDI, G.; MONREAL, I.; PAÑEDA, A.; JUANARENA, N.; ARCELUS, S.; RAZQUIN, N.; GUEMBE, L.;

GONZÁLEZ-ASEGUINOLAZA, G.; PRIETO, J.; FORTES, P. Insulin-like growth factor I gene transfer to cirrhotic liver induces fibrolysis and reduces fibrogenesis leading to cirrhosis reversion in rats. Hepatology, v. 51, n. 3, p. 912-921, 2010.

SPIRA, G.; MAWASI, N.; PAIZI, M.; ANBINDER, N.; GENINA, O.; ALEXIEV, R.; PINES, M. Halofuginone, a collagen type I inhibitor improves liver regeneration in cirrhotic rats. Journal of Hepatology, v. 37, n. 3, p. 331-339, 2002.

STARZL, T. E.; PORTER, K. A.; KASHIWAGI, N.; PUTNAM, C. W. Portal hepatotrofic factors, diabetes mellitus and acute liver atrophy, hypertrophy and regeneration. Surgery Gynecology Obstetric, v. 141, n. 6, p. 46-49, 1975.

STARZL, T. E.; PORTER, K. A.; WATANABE, K.; PUTNAM, C. W. Effects of insulin, glucagon, and insulin/glucagon infusions on liver morphology and cell division after complete portocaval shunt in dogs. The Lancet, v. 1, p. 821, 1976.

STEFANOVIC, B.; STEFANOVIC, L.; SCHNABL, B.; BATALLER, R.; BRENNER, D. A. TRAM2 protein interacts with endoplasmic reticulum Ca2+ pump Serca2b and is necessary for collagen type I synthesis. Molecular and Cellular Biology, v. 24, n. 4, p. 1758-1768, 2004.

STEILING, H.; MÜHLBAUER, M.; BATAILLE, F.; SCHÖLMERICH, J.; WERNER, S.; HELLERBRAND, C. Activated hepatic stellate cells express keratinocyte growth factor in chronic liver disease. The American Journal of Pathology, v. 165, n. 4, 1233-1241, 2004.

STROMBECK, D. R.; GRIBBLE, D. Chronic active hepatitis in the dog. Journal of the American Veterinary Medical Association, v. 173, n. 4, p. 380-386, 1978.

TAN, C. K.; CASTILLO, C.; SO, A. G.; DOWNEY, K. M. An auxiliary protein for DNA polymerase-delta from fetal calf thymus. The Journal of Biological Chemistry, v. 261, n. 26, p. 12310-12316, 1986. 
TANGERMAN, A.; MEUWESE-ARENDS, M. T.; JANSEN, J. B. Cause and composition of foetor hepaticus. Lancet, v. 343, n. 8895, p. 483, 1994.

TARLÁ, M. R.; RAMALHO, F. S.; RAMALHO, L. N. Z.; CASTRO e SILVA, T.; BRANDÃO, D. F.; FERREIRA, J.; CASTRO e SILVA, O.; ZUCOLOTO, S. A molecular view of liver regeneration. Acta Cirúrgica Brasileira, v. 21, p. 58-62, 2006a. Supplement 1.

TARLÁ, M. R.; RAMALHO, F.; RAMALHO, L. N. Z.; CASTRO e SILVA, T.; BRANDÃO, D. F.; FERREIRA, J.; CASTRO e SILVA, O.; ZUCOLOTO, S. Cellular aspects of liver regeneration. Acta Cirúrgica Brasileira, v. 21, p. 63-66, 2006b. Supplement 1.

TESTA, R.; FRANCESCHINI, R.; GIANNINI, E.; CATALDI, A.; BOTTA, F.; FASOLI, A.; TENERELLI, P.; ROLANDI, E.; BARRECA, T. Serum leptin levels in patients with viral chronic hepatitis or liver cirrhosis. Journal of Hepatology, v. 33, n. 1, p. 33-37, 2000.

THEISE, N. D.; SAXENA, R.; PORTMANN, B. C.; THUNG, S. N.; YEE, H.; CHIRIBOGA, L.; KUMAR, A.; CRAWFORD, J. M. The canals of Hering and hepatic stem cells in humans. Hepatology, v. 30, n. 6, p. 1425-1433, 1999.

THOMPSON, G. R.; BARROWMAN, J.; GUTIERREZ, L.; DOWLING, R. H. Action of neomycin on intraluminal phase of lipid absorption. The Journal of Clinical Investigation, v. 50, n. 2, p. 319-323, 1971.

TORRES, S.; DÍAZ, B. P.; CABRERA, J. J.; DÍAZ-CHICO, J. C.; DÍAZ-CHICO, B. N.; LÓPEZ-GUERRA, A. Thyroid hormone regulation of rat hepatocyte proliferantion and polyploidization. American Journal of Physilogy - Gastrointestinal and Liver Physiology, v. 276, n. 1, p. 155-163, 1999.

TSAMANDAS, A. C.; ANTONACOPOULOU, A.; KALOGEROPOULOU, C.; TSOTA, I.; ZABAKIS, P.; GIANNOPOULOU, E.; LIAVA, A.; TZELEPI, V.; TEPETES, K.; PETSAS, T.; KARDAMAKIS, D.; KALOFONOS, H. P. Oval cell proliferation in cirrhosis in rats: an experimental study. Hepatology Research, v. 37, n. 9, p. 755-764, 2007.

TSUKADA, S.; PARSONS, C. J.; RIPPE, R. A. Mechanisms of liver fibrosis. Clinica Chimica Acta; International Journal of Clinical Chemistry, v. 364, n. 1-2, p. 33-60, 2006.

TÚNEZ, I.; MUNÕZ, M. C.; VILLAVIVENCIO, M. A.; MEDINA, F. J.; PRADO, E. P.; ESPEJO, I.; BARCOS, M.; SALCEDO, M.; FEIJÓO, M.; MONTILLA, P. Hepato- and neurotoxicity induced by thioacetamide: protective effects of melatonin and dimethulsulfoxide. Pharmacological Research, v. 52, n. 3, p. 223-228, 2005.

USAMI, M.; FURUCHI, K.; OGINO, M.; KSASAHARA, H.; KANAMURA, T.; SAITOH, Y.; YOKOYAMA, H.; KANO, S. The effect of a nucleotide-nucleoside solution of hepatic regeneration after partial hepatectomy in rats. Nutrition, v. 12, p. 797-803, 1996.

VAN DER VOORT, R.; TAHER, T. E.; DERKSEN, P. W.; SPAARGAREN, M.; VAN DER NEUT,R.; PALS, S. T. The hepatocyte growth factor/Met pathway in development, tumorigenesis, and B-cell differentiation. Advances in Cancer Research, v. 79, p. 39-90, 2000 . 
VAN THIEL, D. H.; GAVALER, J. S.; KAM, I.; FRANCAVILLA, A.; POLIMENO, L.; SCHADE, R. R.; SMITH, J.; DIVEN, W.; PENKROT, R. J.; STARZL, T. E. Rapid growth of an intact human liver transplanted into a recipient larger than the donor. Gastroenterology, v. 93, n. 6, p. 1414-1419, 1987.

VAN WART, H. E.; BIRKEDAL-HANSEN, H. The cysteine switch: a principle of regulation of metalloproteinase activity with potential applicability to the entire matrix metalloproteinase gene family. Proceedings of the National Academy of Sciences of the United States of America, v. 87, n. 14, p. 5578-5582, 1990.

VASSALLI, J. D.; BACCINO, D.; BELIN, D. A cellular binding site for the Mr 55,000 form of the human plasminogen activator, urokinase. The Journal of Cell Biology, v. 100, n. 1, p. 86-92, 1985.

VASSALLI, J-D.; SAPPINO, A-P.; BELIN, D. The plasminogen activator/plasmin system. The Journal of Clinical Investigation, v. 88, n. 4, p. 1067-1072, 1991.

VERCELINO, R.; CRESPO, I.; De SOUZA, G. F.; CUEVAS, M. J.; De OLIVEIRA, M. G.; MARRONI, N. P.; GONZÁLEZ-GALLEGO, J.; TUÑÓN, M. J. S-nitroso-N-acetylcysteine attenuates liver fibrosis in cirrhotic rats. Journal of Molecular Medicine, v. 88, n. 4, p. 401$411,2010$.

VLAHCEVIC, Z. R.; BUHAC, I.; FARRAR, J. T.; BELL JR, C. C.; SWELL, L. Bile acid metabolism in patients with cirrhosis. I. Kinetic aspects of cholic acid metabolism.

Gastroenterology, v. 60, n. 4, p. 491-498, 1971.

VLODAVSKY, I.; FRIEDMANN, Y. Molecular properties and involvement of heparanase in cancer metastasis and angiogenesis. The Journal of Clinical Investigation, v. 108, n. 3, p. 341-347, 2001.

VLODAVSKY, I.; FRIEDMANN, Y.; ELKIN, M.; AINGORN, H.; ATZMON, R.; ISHAIMICHAELI, R.; BITAN, M.; PAPPO, O.; PERETZ, T.; MICHAL, I.; SPECTOR, L.; PECKER, I. Mammalian heparanase: gene cloning, expression and function in tumor progression and metastasis. Nature Medicine, v. 5, n. 7, p. 793-802, 1999.

WALKER, N.; APE1, R.; KERLIN, P.; HORN, M.; TINNISWOOD, R.; LYNCH, S.; STRONG, R. Hepatitis B virus infection in liver allografts. The American Journal of Surgical Pathology, v. 17, n. 7, p. 666-677, 1993.

WANG, D. R.; SATO, M.; LI, L. N.; MIURA, M.; KOJIMA, N.; SENOO, H. Stimulation of pro-MMP-2 production and activation by native form of extracellular type I collagen in cultured hepatic stellate cells. Cell Structure and Function, v. 28, n. 6, p. 505-513, 2003.

WANG, G. S.; ERIKSSON, L. C.; XIA, L.; OLSSON, J.; STAL, P. Dietary iron overload inhibits carbon tetrachloride-induced promotion in chemical hepatocarcinogenesis: effects on cell proliferation, apoptosis, and antioxidation. Journal of Hepatology, v. 30, n. 4, p. 689698, 1999.

WANG, S. C.; LIEN, H. C.; XIA, W.; CHEN, I. F.; LO, H. W.; WANG, Z.; ALI-SEYED, M.; LEE, D. F.; BARTHOLOMEUSZ, G.; OU-YANG, F.; GIRI, D. K.; HUNG, M. C. 
Binding at and transactivation of the COX-2 promoter by nuclear tyrosine kinase receptor ErbB-2. Cancer Cell, v. 6, n. 3, p. 251-261, 2004.

WANG, T.; SHANKAR, K.; RONIS, M. J. J.; MEHENDALE, H. M. Potentiation of thioacetamide liver injury in diabetic rats is due to induced CYP2E1. Journal of Pharmacology and Experimental Therapeutics, v. 294, n. 2, p. 473-479, 2000.

WATSON, P. J. Chronic hepatitis in dogs: a review of current understanding of the aetiology, progression, and treatment. Veterinary Journal, v. 167, n. 3, p. 228-241, 2004.

WICKS, C.; SOMASUNDARAM, S.; BJARNASON, I.; MENZIES, I. S.; ROUTLEY, D.; POTTER, D.; TAN, K. C.; WILLIAMS, R. Comparison of enteral feeding and total parenteral nutrition after liver transplantation. Lancet, v. 344, n. 8926, p. 837-840, 1994.

WONG, L.; YAMASAKI, G.; JOHNSON, R. J.; FRIEDMAN, S. L. Induction of betaplateletderived growth factor receptor in rat hepatic lipocytes during cellular activation in vivo and in culture. The Journal of Clinical Investigation, v. 94, n. 4, p. 1563-1569, 1994.

XU, L.; ALARCON, C.; COL, S.; MASSAGUE, J. Distinct domain utilization by Smad3 and Smad4 for nucleoporin interaction and nuclear import. The Journal of Biological Chemistry, v. 278, n. 43, p. 42569-42577, 2003.

XUE, W. C.; KHOO, U. S.; NGAN, H. Y.; CHAN, K. Y.; CHIU, P. M.; TSAO, S. W.; CHEUNG, A. N. Minichromosome maintenance protein 7 expression in gestational trophoblastic disease: correlation with Ki67, PCNA and clinicopathological parameters. Histopathology, v. 43, n. 5, p. 485-490, 2003.

YAVORKOVSKY, L.; LAI, E.; ILIC, Z.; SELL, S. Participation of small intraportal stem cells in the restitutive response of the liver to periportal necrosis induced by allyl alcohol.

Hepatology, v. 21, n. 6, p. 1702-1712, 1995.

YEH, C.; MAITRA, A.; LEE, K.; JAN, Y.; CHEN, M. Thioacetamide-induced intestinal-type cholangiocarcinoma in rat: an animal model recapitulating the multi-stage progression of human cholangiocarcinoma. Carcinogenesis, v. 25, n. 4, p. 631-636, 2004.

YOSHIJI, H.; KURIYAMA, S.; YOSHII, J.; IKENAKA, Y.; NOGUCHI, R.; HICKLIN, D. J.; WU, Y.; YANASE, K.; NAMISAKI, T.; YAMAZAKI, M.; TSUJINOUE, H.; IMAZU, H.; MASAKI, T.; FUKUI, H. Vascular endothelial growth factor and receptor interaction is a prerequisite for murine hepatic fibrogenesis. Gut, v. 52, n. 9, p. 1347-1354, 2003.

YU, C.; WANG, F.; JIN, C.; HUANG, X.; MILLER, D. L.; BASILICO, C.; MCKEEHAN, W. L. Role of fibroblast growth factor type 1 and 2 in carbon tetrachloride-induced hepatic injury and fibrogenesis. The American Journal of Pathology, v. 163, n. 4, 1653-1662, 2003.

ZAIDAN DAGLI, M. L.; HERNANDEZ-BLAZQUEZ, F. J. Roles of gap junctions and connexins in non-neoplastic pathological processes in which cell proliferation is involved. Journal of Membrane Biology, v. 218, n. 1-3, p. 79-91, 2007. 
ZARAGOZA, A.; ANDRÉS, D.; SARRIÓN, D.; CASCALES, M. Potenciation of thioacetamide by phenobarbital pretreatmente in rats. Inducibility of FAD monooxygenase system and age effect. Chemico-Biological Interactions, v. 124, n. 2, p. 87-101, 2000.

ZATOŃSKI, W. A.; SULKOWSKA, U.; MAŃCZUK, M.; REHM, J.; BOFFETTA, P.; LOWENFELS, A. B.; LA VECCHIA, C. Liver cirrhosis mortality in Europe, with special attention to Central and Eastern Europe. European Addiction Research, v, 16, n. 4, p. 193$201,2010$.

ZEN, Y.; SASAKI, M.; FUJII, T.; CHEN, T.; CHEN, M.; YEH, T.; JAN, Y.; HUANG, S.; NIMURA, Y.; NAKANUMA, Y. Different expression patterns of mucin core proteins and cytokeratins during intrahepatic cholangiocarcinogenesis from biliary intraepithelial neoplasia and intraductal papillary neoplasm of the bile duct--an immunohistochemical study of 110 cases of hepatolithiasis. Journal of Hepatology, v. 44, n. 2, p. 350-358, 2006.

ZHANG, Z.; ZOU, Z. S.; FU, J. L.; CAI, L.; JIN, L.; LIU, Y. J.; WANG, F. S. Severe dendritic cell perturbation is actively involved in the pathogenesis of acute-on-chronic hepatitis B liver failure. Journal of Hepatology, v. 49, n. 3, p. 396-406, 2008.

ZHANG, Z-T.; JIANG, P.; WANG, Y.; LI, J-S.; XUE, J-G.; ZHOU, Y-Z.; YUAN, Z. Effects of hepatotrophic factors on the liver after portacaval shunt in rats with portal hypertension.

Chinese Medical Journal, v. 119, n. 20, p. 1727-1733, 2006.

ZHENG, W. D.; ZHANG, L. J.; SHI, M. N.; CHEN, Z. X.; CHEN, Y. X.; HUANG, Y. H.; WANG, X. Z. Expression of matrix metalloproteinase-2 and tissue inhibitor of metalloproteinase-1 in hepatic stellate cells during rat hepatic fibrosis and its intervention of IL-10. World Journal of Gastroenterology, v. 11, n. 12, p. 1753-1758, 2005.

ZHONG-TAO, Z.; PENG, J.; YU, W.; JIAN-SHE, L.; JIAN-GUO, X.; YAN-ZHONG, Z.; ZHU, Y. Effects of hepatotrophics factors on the liver after portocaval shunt in rats with portal hypertention. Chinese Medical Journal, v. 119, n. 20, p. 1727-1733, 2006.

ZIMMERMAN, H.; REICHEN, J.; ZIMMERMAN, A.; SAGSSER, H.; THENISCH, B.; HOFLIN, F. Reversibility of secondary biliary fibrosis by biliodigestive anastomosis in the rat. Gastroenterology, v. 103, n. 2, p. 579-589, 1992. 